Flávio Leal Maranhão

\title{
MÉTODO PARA REDUÇÃO DE MANCHA NAS VEDAÇÕES EXTERNAS DE EDIFÍCIOS
}


Flávio Leal Maranhão

\section{MÉTODO PARA REDUÇÃO DE MANCHA NAS VEDAÇÕES EXTERNAS DE EDIFÍCIOS}

Tese apresentada à Escola Politécnica da Universidade de São Paulo para obtenção do título de Doutor em Engenharia

São Paulo 

Flávio Leal Maranhão

\section{MÉTODO PARA REDUÇÃO DE MANCHA NAS VEDAÇÕES EXTERNAS DE EDIFÍCIOS}

Tese apresentada à Escola Politécnica da Universidade de São Paulo para obtenção do título de Doutor em Engenharia

Orientador: Prof. Livre-Docente Vanderley Moacyr John

São Paulo 
FICHA CATALOGRÁFICA

Maranhão, Flávio Leal

Método para redução de mancha nas vedações externas de edifícios / F.L. Maranhão. -- São Paulo, 2009.

$107 \mathrm{p}$.

Tese (Doutorado) - Escola Politécnica da Universidade de São Paulo. Departamento de Engenharia de Construção Civil.

1. Fachadas 2. Fungos 3. Poluição atmosférica 4. Revesti mento de superfície I. Universidade de São Paulo. Escola Politécnica. Departamento de Engenharia de Construção Civil II. t. 


\section{DEDICATÓRIA}

À minha amada Cris

Aos meus pais Ricardo e Rosa

Aos meus irmãos Fred, Marise e Laura

Ao meu sobrinho Dudu

Ao Santa Cruz Futebol Clube 


\section{AGRADECIMENTOS}

Ao Departamento de Construção Civil da Escola Politécnica da USP, em especial ao meu orientador prof. Dr. Vanderley Moacyr John e Prof. Dra. Kai Loh que sempre foram fonte de incentivo, apoio e inspiração.

Além desses, agradeço aos professores Dr.Ubiraci Souza, Dr.Mercia de Barros, Dr.Antonio Figueiredo, Dr.Maria Alba Cincotto, Dr.Silvio Melhado, Dr.Francisco Cardoso, Dr.Rafael Pillegi, Dr.Philippe Deshayes (École Central Lille), Dr.Julia Kus (ITU Faculty of Architecture), Dr.Douglas Gouvêa, Dr.Henrique Kahn, Dr.Antonio Figueiredo, Dr.Celso Fernandes (UFSC), Dr.Luiz Roberto Prudênicio (UFSC), que muito me ensinaram ao longo de toda a pósgraduação, seja nas disciplinas cursadas, seja nas conversas de corredor.

Ao grande time de apoio da Escola Politécnica que faz um eficiente trabalho de bastidor e possibilita o bom andamento das pesquisas. Em especial: Leonor Machado, Engracia Bartuciotti, Edson Timóteo, Patrícia Freitas, Paulo, Rogério de Toledo, Maria de Fátima, Fátima Regina e Alcione Anaya.

A todo o time da Universidade São Judas Tadeu, em especial aos prof. Msc. Theophilo Guimarães e prof. Dr. Ângelo Sebastião Zanini, que abriram as portas para a docência e são exemplos de dedicação à engenharia e a licenciatura. Além deles, merecem ser lembrados todos os meus alunos, que sempre foram o principal estímulo para as pesquisas sobre os materiais e métodos de construção.

Ao time da Dow Corning Corporation em especial Gislene Meyer, David Selley, Jennifer Middleton, Jorge Venardos e Marcos Antonio Souza, que foram essenciais para o aprofundamento no mundo dos hidrofugantes à base de silicone.

Às empresas Clariant, Evonik e Minérios de Bom Jardim que contribuíram de maneira muito importante para o desenvolvimento dos experimentos.

À minha super amiga Liz Zanchetta D'Agostino e Mariane Brumatti, fundamentais para a realização dos ensaios, análises e interpretações dos resultados da Microscopia Eletrônica de Varredura.

À Fausto Viana e o grupo do Laboratório de Processos Cerâmicos pelo apoio nos ensaios de FTIR.

Ao pessoal do Laboratório de Microestrutura. Em especial os estagiários Harry, Marina, Kelly e Dayse que sempre auxiliaram com muita dedicação e atenção.

Aos meus grandes amigos: Ubiraci Souza, Thiago Melanda; Andrea Bettioli e família; Angelo, Claudia e toda a família Just; Carlos Regattieri, Carine, Andreia e toda a turma da Engemix; Alexandre, Odair e todo o pessoal da Wacker; Aluizio Caldas e Maria; João 
Marcello, Angélica e toda família Pereira da Costa; Tiberio, Alessandra e a família Correia; Daniel Sentone; Brunoro Giordano; Cleber Dias e família; Juarez Hoppe; Waleska Barbosa; Dorval, Andreia, Pedro, Marcia, Ednelson e toda galera de Floripa; Maurício Resende; Maurício Bernardes; Alexandre Britez; Cesar Romano; Mario Takeashi e família; Maza, Fabricio e todo o pessoal da Vivenda Nobre; Luis Fernando e Patrícia; Edmilson Campante, Cinthia e Fernadinho; Thais e José maluco; companheiros do futebol (em especial Arthur e o Baiano), da lanchonete e do rock; é muita gente para agradecer....

Aos meus companheiros de escrita solitária: Fofão (meu cachorro), Lulina, Morbid Angel, Deicide, Carcass, Bach, CSS, Mombojo, Beatles, tramavirtual, Macaco Bong, Tie, entre outros.

Um agradecimento super-especial a: Antonio Acácio e família; Henrique e Monica Gomes; Jose Raimundo Neto e família; Edamek Lima Leite; Henrique Maia (louro) e família; Marcio Menezes (manga); Gustavo Carneiro Leão e família; Nelson Coelho e família; Ana Carla Moura e família; Claudia Nascimento e família; Julio Souza e Max Junginguer.

À minha família de São Paulo: Sergio Anglo; Daniel Ohnuma, Maria Cristiana e Pedro; Erika Paiva, Anderson e Bruna; Luciana Oliveira, Alexandre e Mateus.

Aos meus amigos-irmãos: Gustavo Albuquerque (ferrugem) e Francisco Soares (Chiquinho) que são companheiros de décadas.

À toda a minha grande família: tias, tios, primos, sobrinhos. Tanto lá em Recife (originais) como de Blumenau (agregados).

Um agradecimento muito especial à Rodrigo Maranhão (Didigo) e Ana Claudia (Cacau) que são mais irmãos do que primos.

Aos meus irmãos de sangue Marise, Fred e Laura, eternos amigos e companheiros de todas as horas e batalhas. Agradeço, também, aos seus respectivos cônjuges Rodrigo Mota e Andreia Coelho que vieram completar a família e os divertidos almoços aos domingos.

Ao meu sobrinho lindo Eduardo Maranhão (Dudu).

Aos meus pais Ricardo e Rosa que sempre foram, e continuarão a ser, professores, exemplos, amigos e ídolos em todos os aspectos .... muito obrigado por tudo.

A minha amada esposa Cris por me fazer mais feliz a cada dia e ser um exemplo de entrega em tudo que faz na vida: trabalho, estudo, família .... 


\section{MÉTODO PARA REDUÇÃO DE MANCHA NAS VEDAÇÕES EXTERNAS DE EDIFIFÍCIOS}

\section{RESUMO}

O permanente contato das vedações externas dos edifícios com os materiais integrantes das vedações externas dos edifícios (fachadas e telhados) com os agentes de degradação provocam o surgimento de manchas, que normalmente estão associadas à deposição de poluentes e a proliferação de microorganismos. Para inibir o surgimento dessas manchas existem, atualmente, diversos métodos disponíveis, sendo que nenhum tem se mostrado efetivo.

Esta tese de doutorado, com base em um extenso programa laboratorial - com o uso de métodos como MEV, FTIR, ângulo de contato, crescimento acelerado de microrganismos, atividade fotocatalítica, entre outros-, criou um novo método, destinado aos materiais de construção silicosos e porosos, que se baseia na modificação de suas propriedades superficiais, por meio da sobreposição de uma camada hidrofóbica por uma hidrofílica.

Para se obter essa disposição superficial, utilizou-se um hidrofugante à de octilsilicone, que apresenta elevada repelência à água e maior durabilidade, e um semicondutor à base de dióxido de titânio, que apresenta atividade fotocatalítica quando incidido por radiação ultravioleta.

Como resultado, o método proposto (denominado na tese por $\mathrm{WR}+\mathrm{TiO}_{2 \text {-sequencial) }}$ apresenta, comprovadamente, os seguintes benefícios: (i) redução de manchas causadas pela adesão de partículas com características apolares, similares às partículas de poluição dos grandes centros urbanos; (ii) limpeza espontânea de certos tipos de manchas, decorrentes dos processos fotocatalíticos que promovem a oxidação/redução de matéria orgânica; (iii) inibição do crescimento de microrganismo em escala laboratorial; (iv) redução da absorção total de água e, principalmente, da cinética do ganho de massa.

Por isso, edificações cujas vedações externas venham a ser tratadas com o método aqui proposto são, potencialmente, células ativas para a sustentabilidade do ambiente construído, pois: reduzem o consumo de energia, reduz os custos de manutenção e contribuem para despoluição da atmosfera urbana. 


\section{METHOD TO REDUCE SOILING DEPOSITION ON BUILDING ENVELOPE}

\section{ABSTRACT}

Building roofs and façades usually show blackening surfaces after few years in large cities. On porous and silicious materials those soiling is caused by particles pollution depositions and mould growth, and the available methods available to prevent this phenomenum do not have a good performance along it's service life.

This thesis, based on an intensive laboratory research with many test technics as SEM, FTIR, contact angle, accelereted mould growth, and photocatalytical activity, create a new method to prevent soiling on porous and silicous building materials. This method modify the materials surface properties, making the outer surface layers with nano-actived titanium dioxide particles, which has photocatalitycal activity under UV radiation, and below it a hydrophobic layer, composed by octyl-silicones.

The main results in laboratory scale experiments obtained by this new method (socalled in this thesis by $\mathrm{WR}+\mathrm{TiO}_{2}$-sequencial) are: (i) stainings reductions caused by apolar agent, (ii) self-cleaning properties for some stain and after UV radiation exposition, (iii) mould growth resistance, and (iv) water absorption reduction.

As a consequences, building envelopes trated with the new method is supposed to contribute to built and environment sustantability, because: can reduce the energy consumption, reduce de maintenance costs e has a de-pollution properties. 


\section{Sumário}

RESUMO

ABSTRACT

LISTA DE FIGURAS

CAPÍTULO I

Introdução 1

1.1 Agentes Causadores das Manchas 3

1.1.1 Poluentes Atmosféricos 3

1.1.2 Proliferação de Microrganismos 3

1.1.3 Avaliação Crítica 5

1.2 Técnicas com Potencial para Redução de Manchas 6

1.2.1 Hidrofugação 6

1.2.2 Alteração da Emissividade de Raios Infravermelhos (IR)

1.2.3 Fotocatálise 9

1.3 Análise 9

1.4 Hipótese e Objetivos $\quad 10$

1.5 Estratégia para Desenvolvimento da Tese 10

$\begin{array}{lll}1.6 & \text { Estrutura da Tese } & 12\end{array}$

CAPÍTULO II $\quad 13$

Hidrofugante nos Materiais de Construção Porosos 13

2 Introdução 13

$2.1 \quad$ Hidrofugantes $\quad 15$

2.2 Ação dos Hidrofugantes nos Materiais Porosos 21

2.3 Fatores que Influenciam no Desempenho dos Hidrofugantes 22

2.3.1 Forma de Aplicação 22

2.3.2 Propriedades do Substrato e Profundidade de Penetração do Hidrofugante 23

2.3.3 Teor de Materiais Ativos 24

2.3.4 Presença de Fissuras $\quad 25$

2.4 Durabilidade 25

2.5 Influência dos Hidrofugantes no Surgimento de Manchas 26

2.6 Análise do Capítulo 28

CAPÍTULO III $\quad 29$

Fotocatálise Aplicada aos Materiais de Construção 29 
3 Introdução

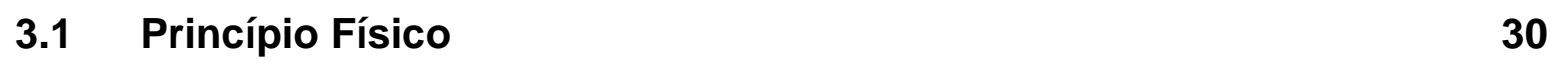

3.1.1 Fatores que Influenciam no Desempenho da Fotocatálise 32

3.2 Mecanismo de Funcionamento 34

3.3 Aplicações da Fotocatálise 36

3.4 Produção de Superfícies com Propriedades Fotocatalíticas 38

$\begin{array}{lll}3.5 & \text { Durabilidade } & 41\end{array}$

3.6 Análise do Capítulo 42

CAPÍTULO IV $\quad 44$

Avaliação de Alternativas para Obtenção de uma Superfície com Propriedades Fotocatalíticas 44

4 Introdução $\quad 44$

4.1 Objetivos $\quad 45$

$4.2 \quad$ Hipótese Experimental 45

$\begin{array}{lll}4.1 & \text { Planejamento Experimental } & 47\end{array}$

4.1.1 Materiais 48

4.1.2 Métodos 51

4.1.2.1 Manchas da Aplicação $\quad 51$

4.1.2.2 Atividade Fotocatalítica 51

4.1.2.3 Silicone como Agente de Ligação do Dióxido de Titânio 52

4.2 Avaliação dos Resultados $\quad 54$

4.2.1 Manchas da Aplicação $\quad 54$

4.2.2 Atividade fotocatalítica 56

4.2.3 Silicone como Agente de Ligação do Dióxido de Titânio 64

4.3 Conclusões do Capítulo $\quad 72$

$\begin{array}{ll}\text { CAPÍTULO V } & 74\end{array}$

Avaliação da Eficiência do Método Proposto na Prevenção de Manchas 74

5 Introdução $\quad 74$

$\begin{array}{lll}5.1 & \text { Objetivo } & 74\end{array}$

$\begin{array}{lll}5.2 & \text { Planejamento Experimental } & 75\end{array}$

$\begin{array}{lll}\text { 5.3 Materiais e Métodos } & 76\end{array}$

$\begin{array}{lll}\text { 5.3.1 Cinética de absorção d'água } & 77\end{array}$

$\begin{array}{lll}\text { 5.3.2 Crescimento de fungos } & 77\end{array}$

$\begin{array}{lll}\text { 5.3.3 Resistência ao Manchamento } & 78\end{array}$

5.3.4 Limpeza espontânea de manchamento 78 
$\begin{array}{lll}\mathbf{5 . 4} & \text { Análise dos Resultados } & \mathbf{7 9}\end{array}$

5.4.1 Cinética de Absorção D'água 79

5.4.2 Crescimento de Fungos 81

5.4.3 Resistência ao Manchamento 82

5.4.4 Limpeza Espontânea do Manchamento 85

5.5 Conclusões do Capítulo 87

CAPÍTULO VI $\quad 88$

Conclusões 88

6.1 Sugestões para Trabalhos Futuros

REFERÊNCIAS BIBLIOGRÁFICAS 94 


\section{Capitulo I}

Figura 1- 1: llustração de manchas em telhados onde há incidência direta de água na forma líquida. (a) telhas cerâmicas na cidade de Blumenau - Santa Catarina; (b) telha de concreto na cidade de Blumenau - Santa Catarina; (c) telhas de fibrocimento na cidade de Campos de Jordão São Paulo; e (d) telha de concreto na cidade de São Paulo.

Figura 1- 2: Crescimento de microrganismos em função do tipo de substrato com umidade e temperatura constantes. Ristchkoff et. al. (2000) apud Sedlbauer (2001).

Figura 1- 3: Esquema ilustrativo da contribuição da poluição e do crescimento de microorganismos no surgimento de manchas na superfície dois edifícios. Baseado em Turkington et. al. (2003)................................. 6

Figura 1- 4: Micrografia da superfície da folha de lótus. Fonte: http://www.botanik.unibonn.de/system/bionik_flash_en.html.

Figura 1- 5: Micrografia de uma gota de água retirando a sujeira de uma superfície revestida com um super-hidrofugante. http://www.corporate.basf.com/en/innovationen/felder/nanotechnologie/f otos/?id=V00-h/pun6u8Lbcp. $x 6$.

Figura 1- 6: Ilustração de manchas causadas pela condensação superficial e posterior proliferação de microrganismo. Nas partes brancas não há condensação.

Figura 1- 7: Diferenças entre a forma de deposição da água em superfície fotoativadas pela ação do UV (http://www.greenquesttek.com/Photocatalyst.html)...........................

Figura 1- 8: Hipótese de alteração das propriedades superficiais para minimização da alteração de cor de materiais de construção silicosos e porosos. ..11

Figura 1- 9: Hipótese da união de produtos com propriedades fotocatalíticas com hidrofugantes à base de silicone para alteração das propriedades superficiais dos materiais de construção silicosos e porosos. ..............11

Figura 2- 1: Isoterma de adsorção ilustrativa de um material poroso. Baseado em Moller (2003).

Figura 2- 2: Possíveis formas de ação dos produtos hidrofugantes nos materiais de construção porosos. (a) alteração da tensão superficial dos poros; (b) bloqueador dos poros; e (c) formador de película. Kus (2002). ........... 16

Figura 2- 3: Ilustrações dos tipos de siloxanos existentes. Fonte: Mayers (1998) ....17 
Figura 2- 4: Ilustração do processo de adesão de um silano a um substrato silicoso, onde $R$ = radical orgânico e OR'= grupo alcoxi. Fonte: Kus (2002).....19

Figura 2- 5: Estrutura química dos Siliconatos (Selley et. al. 2006)........................ 19

Figura 2- 6: Estrutura química do silanos (Mayers, 1998)....................................20

Figura 2- 7: Estrutura química do Siloxano (Mayers, 1998). .................................20

Figura 2- 8: Isotermas de adsorção/dessorção para concretos tratados e não tratados. Direta: relação água/cimento $=0,80$ e esquerda: relação água/cimento $=0,45$. Fonte: Johansson (2006)..............................21

Figura 2- 9: Cinética de secagem de blocos cerâmicos. Fonte: (Sandin, 1996). .....21

Figura 2- 10: Influência do teor de um isoctilsilano adicionado à mistura no surgimento de eflorescências de fibrocimento (placas de $20 \mathrm{~cm} \times 20 \mathrm{~cm}$ ). Os teores referem-se à massa total de materiais secos. Fonte: arquivo pessoal do autor. 23

Figura 2- 11: Profundidade de penetração de um silano em concretos. Selley (2006).

Figura 2- 12: Influência da porosidade na distribuição dos materiais ativos ao longo da espessura de substratos de concreto. Fonte: Gerdes et. al. (1998).

Figura 2- 13: Influência da dimensão da fissura no ganho de umidade de concretos hidrofugados após uma hora de imersão (a) e vinte quatro horas (b). Baseado em: Lunk; Wittmann (1998).

Figura 2- 14: Influência do tipo de radical apolar na proteção da matriz siloxano. (Basheer, Long, 1997).

Figura 2- 15: Influência da tensão superficial na adesão de bactérias. Fonte: Baier apud Zhao et. al. (2005).

Figura 2- 16: llustração do surgimento de manchas causadas pela deposição de partículas de poluição em blocos cerâmicos expostos durante seis meses na cidade de São Paulo. Fonte: Arquivo pessoal.

Figura 3- 1: Esquema de oxidação de redução de semicondutores. $B V=$ Banda de Valência e BC = Banda Condutora.

Figura 3- 2: llustração das diferenças entre os orbitais de compostos condutores, semicondutores e isolantes. Baseado em Ambrosio Junior (sd.)..........31

Figura 3- 3: Influência da concentração de partículas fotoativadas na atividade fotocatalítica.

Figura 3- 4: Diferença de dimensão entre as partículas utilizadas para pigmentos em tintas (standard $\mathrm{TiO}_{2}$ ) e em processos fotocatalíticos (nano $\mathrm{TiO}_{2}$ ). Fonte: Allen et. al. (2008).

Figura 3- 5: Influência do tamanho de partículas de $\mathrm{TiO}_{2}$ na atividade fotocatalítica. Baseado em Jang et. al., 2001 e Koci et. al. (2009). 
Figura 3- 6: Efeito do teor de anatásio na atividade fotocatalítica.

Figura 3- 7: Mecanismo de ação de superfície fotocatalítica. Baseado em WWW.PICADA-PROJECT.COM ...

Figura 3- 8: Cinética do ângulo de ângulo de contato em função da presença ou não da radiação UV. Baseada nos resultados de Guan et. al. (2003), Guan (2005), Irie; Hashumoto (2005), Cai et. al. (2006) e Määttä et. al. (2007).

Figura 3- 9: Exemplos de uso de concretos com propriedades fotocatalíticas. Catedral da Misericórdia (Roma, Itália) e na Central da Polícia (Bordeaux, França). Obtido em http://www.italcementigroup.com no dia 22 de janeiro de 2008.

Figura 3- 10: Fissuras causadas pela atividade fotocatalítica do TiO2 em filmes de poliuretano. (Motohashi; Inukai, 2007). Direta = inicial e esquerda $=$ após 5,5 anos de exposição natural.

Figura 3- 11: Exemplo da aplicação da camada fotocatalítica em duas camadas sobre paver. Fonte: (beldens, sd)

Figura 3- 12: Ação das partículas de vidro na fotoativação do semicondutor.Fonte: Chen; Poon (2009).

Figura 3- 13: Manchas esbranquiçadas em um paver produzido em dois estágios, cuja superfície mais externa apresenta propriedade fotocatalíticas. Fonte: Husken; Brouwers (2008) ... 40

Figura 3- 14: Aplicação do pós-tratamento de concreto com película de $\mathrm{TiO}_{2}$ (Hanehara, 2005).

Figura 3- 15: Redução da atividade fotocatalítica após a moldagem de corpos-deprova cimentícios. $O$ indicador usado no estudo foi a decomposição de atrazina. Baseado em Lackhoff et. al. (2003).

Figura 4- 1: Hidrólise superficial das partículas de dióxido de dióxido de titânio. Baseado em Chen; Ponn (2009).. 46

Figura 4- 2: Processo de hidrólise de hidrofugante genérico à base de silicone.......46

Figura 4- 3: Processo de condensação do hidrofugante à base de silicone e ligação aos substratos silicosos e porosos.

Figura 4- 4: fixação do hidrofugante à base de silicone nos substratos silicosos e porosos na presença de solução de anatásio.

Figura 4- 5: Planejamento experimental para a avaliação de superfícies com propriedades fotocatalíticas.

Figura 4- 6: Caracterização do tamanho de partícula da solução do anatásio utilizado no programa laboratorial. 
Figura 4- 7: Cinética de absorção d'água para os corpos-de-prova de fibrocimento sem-amieto ao longo de 24 horas de imersão. (Maranhão et.al, 2008).

Figura 4- 8: llustração do equipamento utilizado para realizar a ciclos de abrasão dos corpos-de-prova.

Figura 4- 9: (a) Goniômetro utilizado para a avaliação do ângulo de contato e (b) Exemplo de resultado obtido na avaliação do ângulo de contato........52

Figura 4- 10: Esquema da rotina de leitura utilizada no MEV. 54

Figura 4- 11: Aspecto visual de placas de fibrocimento em função do aumento da concentração de $\mathrm{TiO}_{2}$, em relação à massa de água.

Figura 4- 12: Detalhe do aspecto visual das placas de fibrocimento antes e depois da lavagem manual.

Figura 4- 13: Médias do ângulo de contato inicial antes e depois dos ciclos de abrasão, em substratos de vidros. Para cada ponto foram realizadas, no mínimo, dezesseis medições.

Figura 4- 14: Variação característica do ângulo de contato de um corpo-de-prova no substrato de vidro tratado com $\mathrm{wr}+\mathrm{TiO}_{2}$-sequencial ao longo dos dois minutos de ensaio.

Figura 4- 15: Resultados do ângulo de contato inicial medido antes e imediatamente após a exposição à radiação ultravioleta por 4 dias, para as amostras antes e depois dos ciclos de abrasão.

Figura 4- 16: Dispersão de resultados de ângulo de contato inicial no substrato de

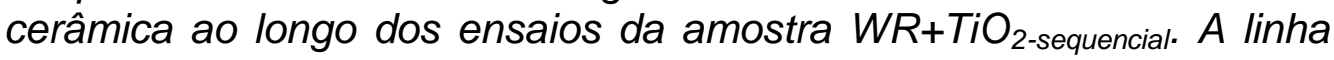
refere-se à mediana dos resultados. .59

Figura 4- 17: Cinética da queda do ângulo de contato imediatamente após a exposição à radiação UV de corpo-de-prova de cerâmica tratadas com $\mathrm{WR}+\mathrm{TiO}_{2}$ - sequencial..

Figura 4-18: Cinética da queda do ângulo de contato após cento e vinte horas após a exposição à radiação UV de corpo-de-prova de cerâmica tratadas com $\mathrm{WR}+\mathrm{TiO}_{2}$ - sequencial.

Figura 4- 19: Cinética da queda do ângulo de contato após duzentos e quarenta horas da exposição à radiação UV de corpo-de-prova de cerâmica tratadas com WR + $\mathrm{TiO}_{2}$ - sequencial. ...............................................62

Figura 4- 20: Comparação do tempo de deposição da gota necessário para atingir valores inferiores a dez graus em substratos de cerâmica tratadas com $\mathrm{WR}+\mathrm{TiO}_{2}$ - sequencial.

Figura 4- 21: Ilustração da variação do ângulo de contato depois da exposição à radiação $U V$.

Figura 4- 22: Resultados do FTIR mostrando a ligação entre o dióxido de titânio e $o$ hidrofugante.

Figura 4- 23: Repetibilidade dos resultados para dois corpos-de-prova da amostras

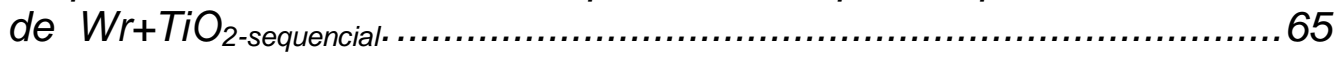

Figura 4- 24: Influência do teor de dióxido de titânio nos resultados de FTIR. 
Figura 4- 25: Resultado da Microscopia Eletrônica de Varredura sobre a amostra de referência. Notar pequena presença do titânio.

Figura 4- 26: Espectros dos cinco pontos obtidos no EDS da amostra tratadas com suspensão aquosa de dióxido de titânio com concentração de 2,00\% de $\mathrm{TiO}_{2}$ antes da abrasão.

Figura 4- 27: Espectros dos cinco pontos obtidos no EDS da amostra tratadas com suspensão aquosa de dióxido de titânio com concentração de 0,50\% de $\mathrm{TiO}_{2}$ antes da abrasão.

Figura 4- 28: Diferença entre a intensidade de picos referente ao titânio no EDS em áreas claras e escuras de um mesmo corpo-de-prova. Aumento de $800 X$.

Figura 4- 29: Influência do teor de dióxido de titânio na intensidade de pico média do titânio no EDS. Cada ponto refere-se a cinco medições.

Figura 4- 30: Espectros dos cinco pontos obtidos no EDS da amostra tratadas com hidrofugante à base de silicone e dióxido de tit6Anio aplicados de maneira sequencial com concentração de 2,0\% de $\mathrm{TiO}_{2}$ antes da abrasão.

Figura 4- 31: Espectros dos cinco pontos obtidos no EDS da amostra tratadas com suspensão aquosa de dióxido de titânio com concentração de 0,5\% de $\mathrm{TiO}_{2}$ antes da abrasão.

Figura 4- 32: Superfície de amostras com 2,0\% de dióxido de titânio sem agente de ligação antes (a) e depois da abrasão (b). Notar a menor presença de aglomerados na superfície do substrato após abrasão. Aumento de $20.000 X$

Figura 4- 33: llustração de um aglomerado de $\mathrm{TiO}_{2}$ depositado na superfície de um corpo-de-prova. Aumento de 100.000X.

Figura 4- 34: Comparação entre a forma de deposição da chuva e a superfície de corpos-de-prova de argamassa expostos em estação de envelhecimento natural na cidade de São Paulo. Fonte: Arquivo pessoal do autor. .73

\section{CapituloV}

Figura 5- 1: Planejamento Experimental do capítulo 5...................................... 76

Figura 5- 2: Ilustração da câmara tropical utilizada no programa de avaliação do crescimento de microorganismos. .................................................... 78

Figura 5- 3: Resultados de absorção de água no substrato da argmassa 1 . ............80

Figura 5- 4: Resultados de absorção de água no substrato no granito .....................80

Figura 5- 5: Absorção percentual de água para a amostra $W R+\mathrm{TiO}_{2 \text {-sequencial............81 }}$ 


\section{CapituloVI}

Figura 6- 1: Comparação entre o manchamento superficial de corpos-de-prova de argamassa após seis meses de exposição na cidade de São Paulo. Notar que as áreas verdes na referência e no TiO2 representam microorganismos.As quebras foram causadas por chuva de granizo ocorrida durante 0 ensaio. ...............................................................90

Figura 6- 2: Sugestão de superfície que une a fotocatálise, super-hidrofugação com o efeito lótus e pigmentos frios. ........................................................92 
Tabela 1: Radicais orgânicos usados nos hidrofugantes à base de silicone (Charola, 1995).

Tabela 2: Propriedades das diferentes fases cristalográficas dos dióxidos de titânio (www.mindat.org).

Tabela 3: Amostras utilizadas nos ensaios de FTIR para a avaliação da ligação química entre o silicone e o dióxido de titânio. 53

Tabela 4: Amostras usada na Microscopia Eletrônica da Varredura (MEV). 54

Tabela 5: Valores mínimos e máximo do ângulo de contato para os diferentes tratamentos superficiais em substratos de cerâmica após abrasão. Valores em graus. $\quad 61$

Tabela 6: resultados da intensidade de pico de titânio medido pela microssonda. 69

Tabela 7: Valores de absorção total de água após o término dos ensaios.

80

Tabela 8: Resultados do crescimento acelerado de microorganismos na câmara tropical. Cada número se refere a um corpo-de-prova. 82

Tabela 9: Resultados característicos de resistência ao manchamento na Argamassa 1 - comprada pronta para o uso.

Tabela 10: Resultados característicos de resistência ao manchamento na Argamassa 2 - dosada especificamente para a tese. 84

Tabela 11: Resultados característicos dos ensaios de limpeza espontânea de manchamento após a exposição radiação UV. 


\section{CAPÍTULO I}

\section{Introdução}

As vedações externas dos edifícios sofrem, ao longo de sua vida útil, processos de degradação que provocam uma contínua queda de desempenho até que sejam atingidos níveis inferiores aos mínimos necessários para cumprir as funções para as quais foram projetados.

Essa degradação ocorre segundo diversos modelos (Shohet, Paciuk, 2004) e depende da relação entre as características do edifício (propriedades dos materiais e do projeto arquitetônico) e os agentes de degradação que incidem sobre ele.

Como consequencia, têm-se grandes prejuízos aos usuários do edifício e a sociedade como um todo, tanto pelas atividades de manutenção/recuperação necessárias quanto pela degradação do ambiente construído (Watkiss et. al., 2001; Rabl, 1999).

Diversas tentativas para alterar este ciclo vêm sendo apresentadas, dentre as quais podem ser citadas:

- desenvolvimento de novos produtos: exemplo de tintas de baixa emissividade, placas de alumínio composto e neoparies;

- alteração de métodos construtivos: caso dos revestimentos não-aderentes com placas de rocha e do uso de argamassas monocapa;

- aplicação de pós-tratamentos: impermeabilização de materiais tradicionais, como é o caso de tijolos e telhas;

- utilização de novos detalhes de projeto que modificam o fluxo da água de chuva;

- uso de novos biocidas nas tintas e nas argamassas, entre outros.

Muitas dessas tentativas, porém, vêm apresentando pouca eficiência e até se tornando a origem de novos problemas (Lewis, McDonald ,1997; Chew e Tan, 2003; Moller, 2002; Shirakawa et. al., 2004 e Maranhão e Barros, 2005).

Dos problemas apresentados pelas vedações externas, as manchas são as primeiras a serem observadas (Flores, 2002), pois alteram os padrões estéticos da edificação e são facilmente percebidas pelos usuários, mesmo quando menos de $3,6 \%$ da superfície é recoberta (Bellan et. al. 2000). Por isso, Seng et. al. (2006) propõe que a resistência ao manchamento deva ser considerada como o principal requisito de desempenho.

Estas manchas são causadas pela deposição de poluentes atmosféricos e pela proliferação de microrganismos e, normalmente, são dependentes da presença de água em sua forma líquida. Isto fica claro na Figura 1- 1 onde telhados em três 
cidades e construídos com diferentes materiais de construção apresentam manchas com configuração semelhante e concentrada onde não há proteção da chuva.

Este primeiro capítulo busca fornecer os subsídios para o estabelecimento das hipóteses e dos objetivos desta tese. Para tanto, está estruturado em três partes: na primeira, são abordados os agentes causadores das manchas; na segunda, as alternativas atualmente disponíveis para a prevenção/redução das manchas; e, na terceira, realiza-se a análise das informações apresentadas, estabelecem-se a hipótese e o objetivo e apresenta-se a metodologia utilizada para o desenvolvimento da tese.
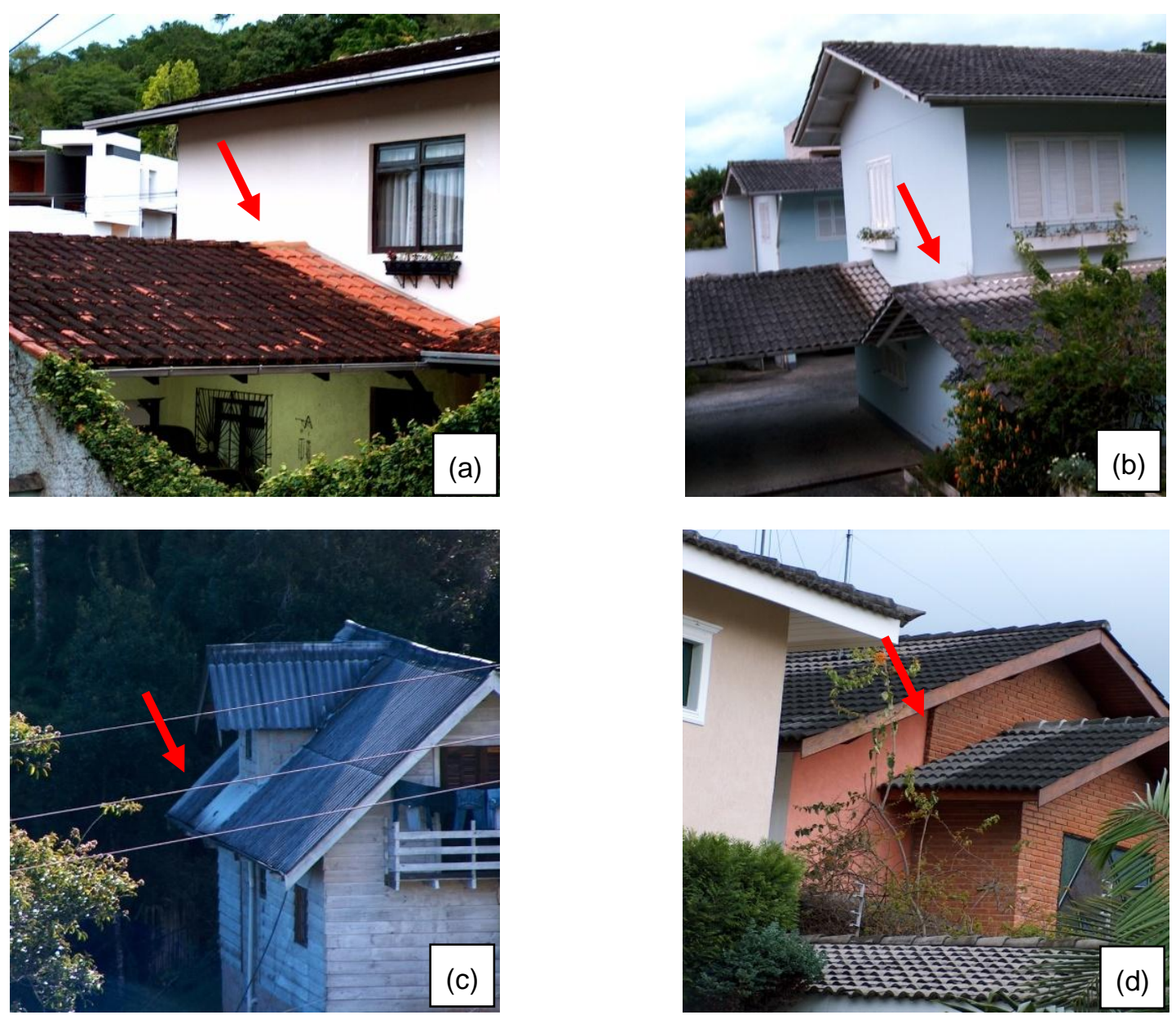

Figura 1- 1: Ilustração de manchas em telhados onde há incidência direta de água na forma líquida. (a) telhas cerâmicas na cidade de Blumenau - Santa Catarina; (b) telha de concreto na cidade de Blumenau - Santa Catarina; (c) telhas de fibrocimento na cidade de Campos de Jordão - São Paulo; e (d) telha de concreto na cidade de São Paulo. 


\subsection{Agentes Causadores das Manchas"}

\subsubsection{Poluentes Atmosfêricos}

Os poluentes atmosféricos que provocam manchas nas edificações são predominantemente compostos por resíduos de combustíveis fósseis e possuem uma composição química contendo $\mathrm{SO}_{x}, \mathrm{NO}_{\mathrm{x}}$ e derivados de carbono (Pio et. al. 1998). Esses compostos, quando em contato com a água de chuva transformam-se em produtos ácidos e provocam importantes degradações nos edifícios (Winkler, 1973; Amoroso; Fassina, 1983; Hamilton et. al.; 1995 e Norvaisiené et. al, 2003).

No setor de edificações, a área de pesquisa mais desenvolvida sobre o fenômeno da deposição de poluentes atmosféricos foca os edifícios com valor histórico, principalmente aqueles construídos com rochas calcárias e mármores.

Essas pesquisas buscam estabelecer um limite para a percepção de poluentes sobre as superfícies, estudar os produtos decorrentes da interação entre os edifícios e os poluentes atmosféricos, correlacionar a concentração de poluentes na atmosfera com a degradação dos edifícios, e avaliar os sistemas de conservação e manutenção utilizados.

Com base nesses estudos já é possível estabelecer que:

- quando a concentração de carbono na poluição atmosférica for superior a $3 \mu \mathrm{g} \cdot \mathrm{m}^{-3}$, as manchas ocorrem com grande intensidade nos edifícios (Brimblecombe; Grossi, 2005);

- superfícies com temperaturas inferiores a do ar facilitam a adesão das partículas de poluição (Verhoef, 1988);

- quanto maior for a dimensão e a massa das partículas de poluição em suspensão mais intensa é a deposição nas superfícies horizontais ou com pouca inclinação. Nas superfície verticais depositam-se as partículas menores (Abadie et. al. (2001);

- em locais onde há concentração de fluxo de água - pingadeiras, por exemplo -, há uma maior intensidade de manchas (Perez, 1986, Dorsey et. al., 1996, Davidson et. al., 2000 e Chen; Tan, 2003);

- quanto mais rugosa for a superfície maior é a taxa de deposição (Grossi et. al., 2003);

- superfícies que apresentam fenômenos de condensação facilitam a adesão de partículas de poluição (Pesava et. al., 1999, e Gaspar; Brito, 2005).

\subsubsection{Proliferação de Microrganismos}

No Brasil os principais microrganismos causadores de manchas nas áreas externas são os fungos, com destaque para o Cladiosporium sp (Shirakawa et. al., 2004), e, nas áreas internas, os Cladiosporium sp, Penicillim e Aspergillus (Shirakawa et. al., 2003).

${ }^{1}$ As pichações não são foco deste trabalho. 
A área de pesquisa que apresenta maior grau de desenvolvimento relacionado à proliferação de microrganismos nos edifícios foca as rochas calcárias, principalmente as consequências dos biofilmes nos edifícios de valor histórico. Percebe-se na Europa e nos Estados Unidos, porém, uma crescente demanda para edifícios dos com poucos anos de uso como consequencia novos de uso sistemas de isolamento térmico das edificações, que facilitam 0 crescimento de microrganismos e causam problemas de saúde aos seus usuários.

Diversos grupos multidisciplinares desenvolvem estudos nessa área, com destaque para o Instituto Fraunhofer de Física das Construções, na Alemanha, o Departamento de Engenharia Civil da Universidade Técnica da Dinamarca, e no Departamento de Construção Civil da Universidade de São Paulo.

De maneira geral, esses grupos desenvolvem pesquisas sobre o entendimento e modelagem do transporte de umidade nos meios porosos, o desenvolvimento de métodos padronizados de ensaios para avaliação da bioreceptividade e da sequência de colonização, a eficiência dos biocidas na prevenção de colonização, e a influência dos produtos hidrofugantes.

A proliferação de microrganismos depende, principalmente, de: (i) umidade e temperatura da superfície; (ii) tempo de molhamento (do inglês time of wetness) e quantidade de água disponível; (iii)propriedades do substrato; (iv) temperatura e umidade do ambiente; e (v) pH da superfície em análise.

A questão da umidade e temperatura da superfície vem sendo estudada por muitos grupos de pesquisa, e há uma concordância de que seus comportamentos são consequencia das propriedades físicas do material e das condições atmosféricas do micro-clima em que está inserido. Além disso, autores como Clarke et. al. (1999), Sedlbauer (2001) e Sato et. al. (2002) estabelecem que umidade relativa acima de $70 \%$ e temperatura superior a $4^{0} \mathrm{C}$, podem ser tomadas como condições mínimas para a proliferação de microrganismos nos materiais de construção. Para avaliações de longo prazo, dez a vinte anos, Kurth (2008) acrescenta que a umidade relativa é o único fator que apresenta boa correlação com o crescimento de microrganismos.

O tempo de molhamento está diretamente correlacionado com o fenômeno de condensação superficial e com as propriedades de adsorção/dessorção do material. Trabalhos como os de Kunzel; Sedlbauer (2001), Sato et. al. (2002) e Becker (2003) esclarecem que o fenômeno de condensação é um dos principais fatores na proliferação de fungos, principalmente em regiões com pouca incidência de chuva direta, pois é a partir dele que são elevados os valores de umidade que facilitam a biocolonização.

A influência do substrato foi investigada por Sedlbauer (2001) e está ilustrado na Figura 1- 2. De acordo com o autor, substratos orgânicos e porosos apresentam maiores taxas de crescimento de microorganismos do que os inorgânicos pois, possuem uma maior disponibilidade de nutrientes e umidade de equilíbrio com 0 meio ambiente. 


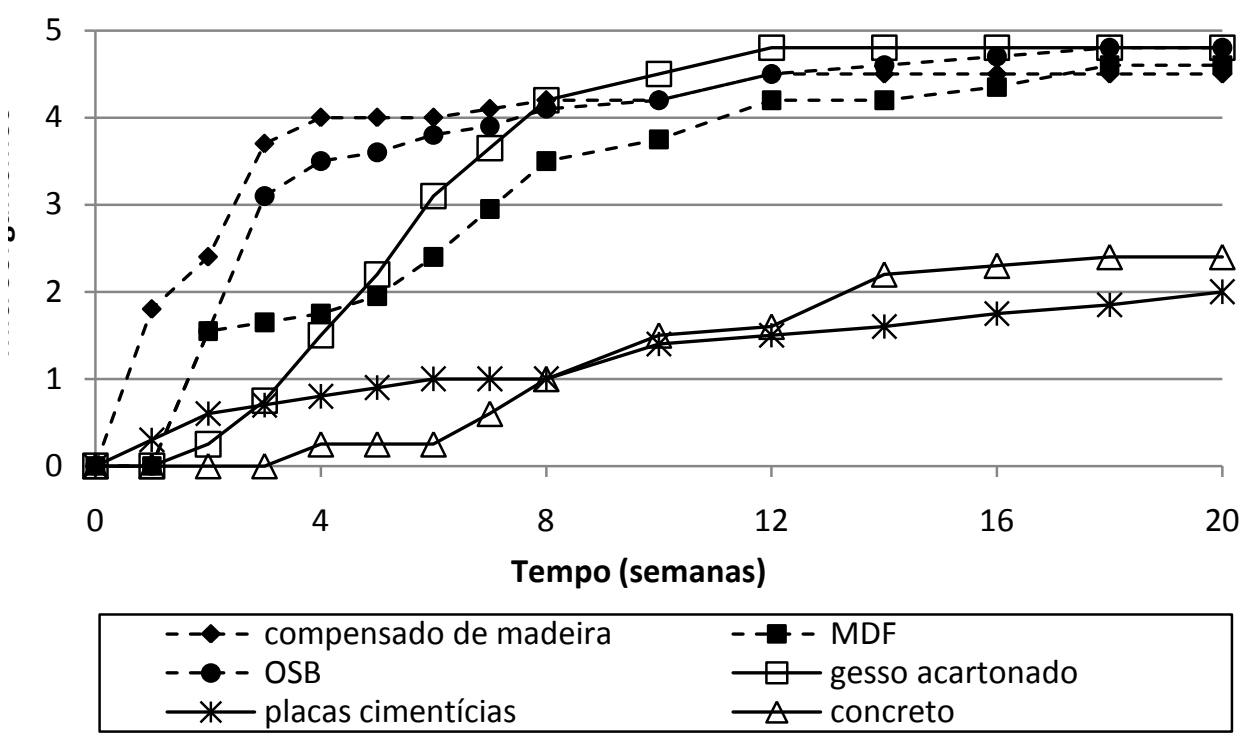

Figura 1- 2: Crescimento de microrganismos em função do tipo de substrato com umidade e temperatura constantes. Ristchkoff et. al. (2000) apud Sedlbauer (2001).

$\mathrm{O}$ pH da superfície é o último fator a exercer grande importância para a proliferação de microrganismos e foi investigado por Shirakawa et. al. (2003). Segundo esses autores, $\mathrm{pH}$ acima de 10 inibem o proliferação de fungos.

Para evitar o crescimento de microorganismos, Kurth (2008) destaca que as duas principais maneiras são: (i) utilização de metais pesados, tais como cobre, zinco, prata, e chumbo (técnica disseminada na área de tintas, mas desaconselhável para os materiais porosos por conta dos riscos de lixiviação) e (ii) fornecimento de oxigênio tóxico, como, por exemplo: peróxido de hidrogênio e ânion radical hidroxila, que podem oxidar os microorganismos.

\subsubsection{Avaliação Crítica}

De tudo apresentado até aqui é possível concluir que a água é o principal agente causador de manchas nas edificações, visto que possibilita as condições para o desenvolvimento de microrganismos e intensifica a deposição de poluentes atmosféricos. Além disso, o seu fluxo não uniforme acelera o surgimento dessas manchas.

Desta forma, é possível estabelecer que em superfícies desprotegidas e sujeita a chuvas e a ciclos de molhagem e secagem há uma rápida proliferação de microrganismos; enquanto que em área protegidas da água de chuva há uma maior intensidade de deposição de partículas de poluição (Figura 1-3). Em ambos os casos, quanto mais rugosa fora a superfície mais rápido o surgimento de manchas. 


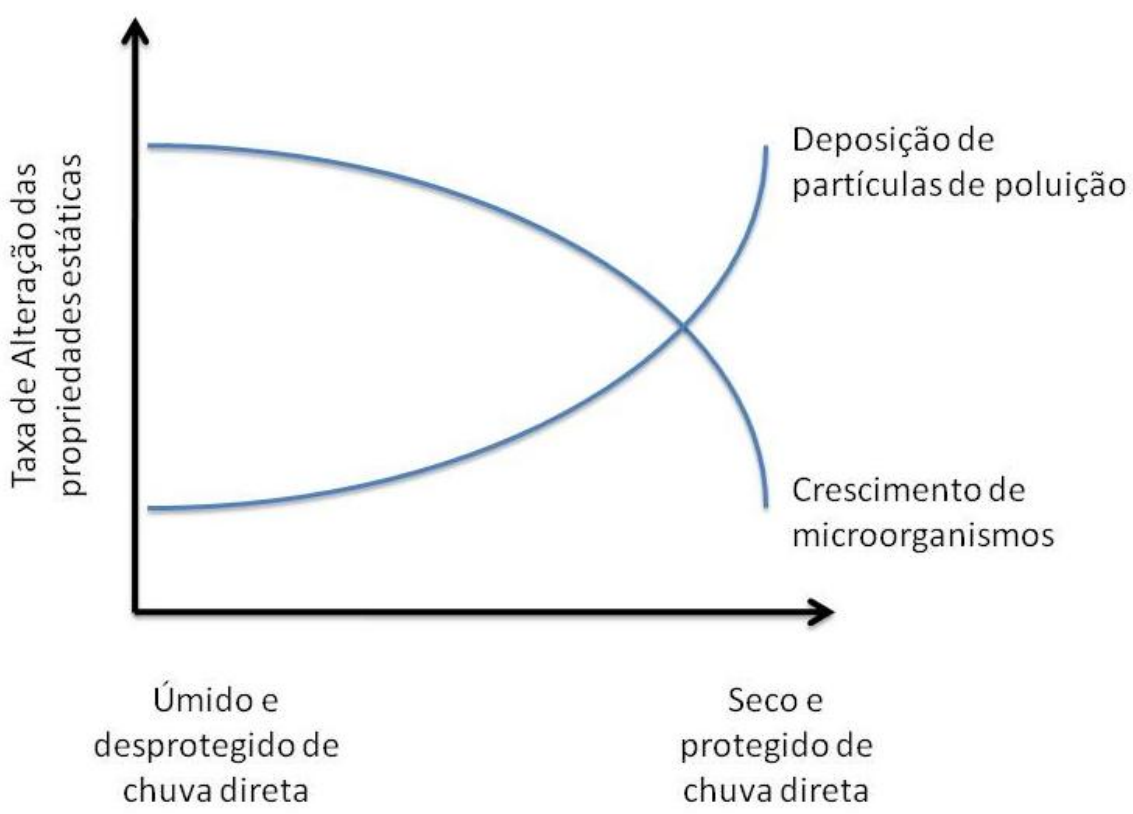

Figura 1- 3: Esquema ilustrativo da contribuição da poluição e do crescimento de microorganismos no surgimento de manchas na superfície dois edifícios. Baseado em Turkington et. al. (2003).

\subsection{Técnicas com Potencial para Reduçã̃o de Manchas}

As tentativas para se evitar ou, ao menos, reduzir o surgimento de manchas nos materiais de construção porosos alteram algumas de suas propriedades superficiais, tais como rugosidade, sucção capilar, tensão superficial, capacidade térmica, dentre outras.

Para tanto, as principais técnicas disponíveis, atualmente, são a hidrofugação, a alteração na emissividade de raios infra-vermelhos (IR) e a fotocatálise.

Cada uma dessas alternativas é abordada nos itens seguintes.

\subsubsection{Hidrofugaçẵo}

É a maneira mais antiga, conhecida e disseminada para proteger os materiais de construção utilizados nas áreas externas, e fundamenta-se no princípio de minimizar, ou mesmo eliminar, a ação da água.

Apresenta a grande a vantagem de não alterar, de maneira radical, os métodos construtivos correntes, de não representar aumentos significativos nos custos, de já possuir um histórico de utilização, e de ser compatível com diversos tipos de materiais (Lork, 2003). 
Diversos produtos hidrofugantes ${ }^{2}$ já vêm sendo utilizados na construção civil, como é o caso de siliconatos, estearatos, silanos, siloxanos, fluorcarbonos, dentre outros (Ferreira, 1993, Esbert, Sanches, 1995, Chioovitti et. al., 1999, Silva et. al., 2000, Ballester, Gonzalves, 2001, e Lu et. al., 2004).

Ocorre que muitos desses produtos estão sujeitos a processos de degradação ao longo de sua vida útil (kus, 2002) e podem até se tornarem na causa de eflorescência (Sadauskiene et. al., 2003 e Moller, 2003) e manchas (Ferreira, 1993, Melo et. al., 1999, Silva et. al., 2001, e Beker, 2003).

Recentemente os pesquisadores W. Barthlott e C. Neinhuim da Universidade de Boon, Alemanha (http://www.botanik.uni-bonn.de), identificaram que as folhas de lótus possuem uma combinação de rugosidade superficial em escala micro e nanométricas, revestidas com material hidrofugante (Figura 1- 4 e Figura 1- 5). Esta união confere propriedades auto-limpantes pelo efeito de rolamento das gotas de água (Cheng et. al , 2006)

Desde essa descoberta, empresas como Bayer, Basf e Degussa já apresentaram ao mercado produtos que prometem efeitos auto-limpantes, utilizando-se dos princípios da folha de lótus (lotus effect). Produtos com essas características são denominados super-hidrofugantes, visto que possuem um ângulo de contato com a água superior a $140^{\circ}$ (Yan et. al., 2003; Junghoon et. al., 2004; Hsieh et. al., 2005).

Por serem produtos com pouco tempo de aplicação, ainda não há subsídios para prever o seu desempenho, ao longo de sua vida útil, na prevenção de manchas nos edifícios.

Moller (2003) acrescenta que os produtos super-hidrofugantes, quando em condições de serviço, não são capazes de eliminar, por completo, as manchas, pois não conseguem reproduzir a rugosidade da folha de lótus e porque o efeito rolamento não retira as partículas que ficam entre os picos e vales superficiais.

\subsubsection{Alteraçầo da Emissividade de Raios Infravermelhos (IR)}

Essa técnica baseia-se no uso de partículas com elevados índices de reflexão da radiação Infravermelho, normalmente metálicas e cerâmicas de dimensões nanométricos, impedindo a absorção de calor durante o dia e reduzindo problemas de condensação superficial.

Kunzel, Sedlbauer (2001) e Kunzel et. al. (2002) apresentaram uma série de dados onde o uso dessa técnica inibiu o surgimento de manchas causadas pela proliferação de microrganismos de corpos-de-prova expostos ao envelhecimento natural na Alemanha. Moller (2003) acrescenta que esta técnica é capaz de reduzir até $50 \%$ da umidade nos materiais de construção porosos em países frios.

\footnotetext{
2 Produtos formadores de filme como resinas acrílicas, poliamidas e poliuretanos não são considerados neste trabalho.
} 

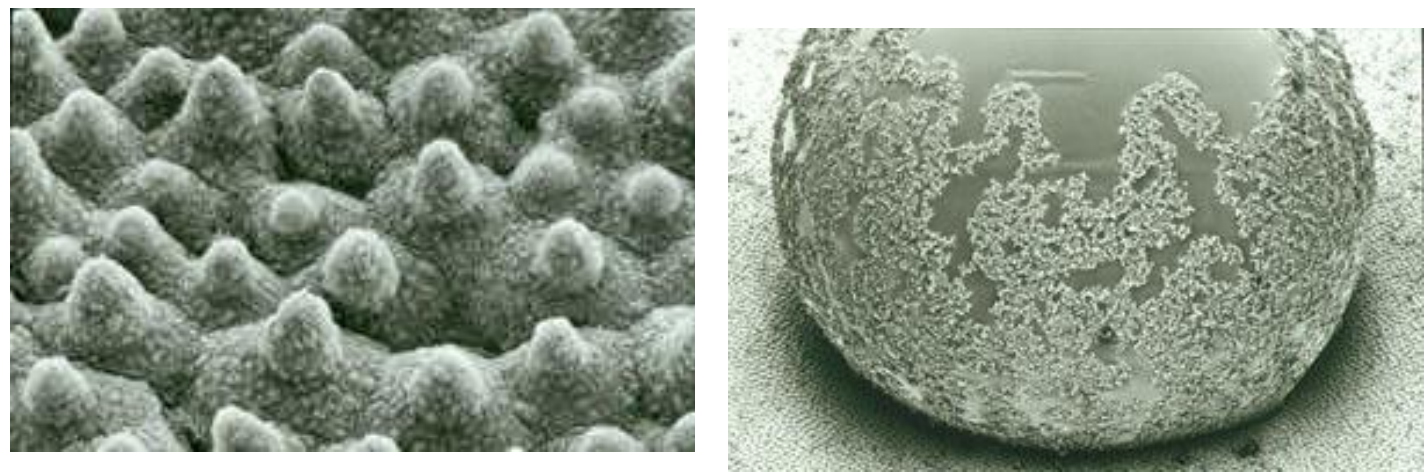

Figura 1- 4: Micrografia da Figura 1- 5: Micrografia de uma gota superfície da folha de lótus. Fonte: de água retirando a sujeira de uma http://www.botanik.uni-

bonn.de/system/bionik_flash_en.html superfície revestida com um superhidrofugante.

http://www.corporate.basf.com/en/innovatione n/felder/nanotechnologie/fotos/?id=V00-

hlpun6u8Lbcp.x6

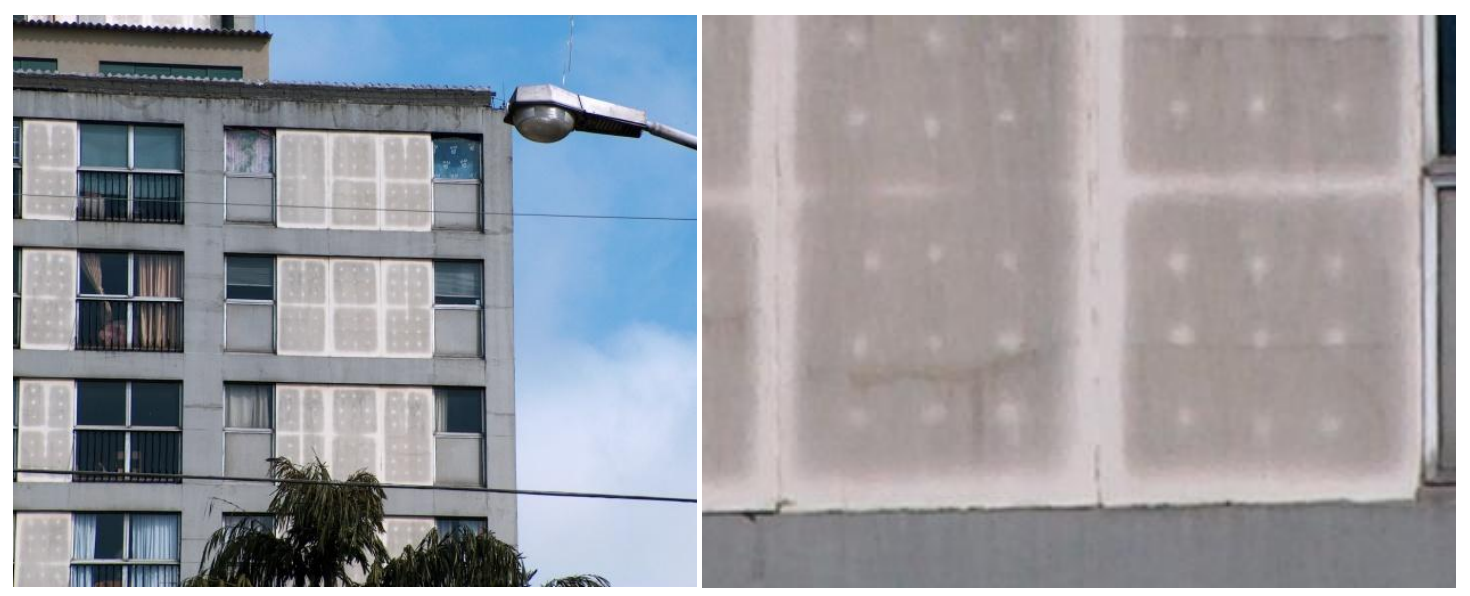

Figura 1- 6: llustração de manchas causadas pela condensação superficial e posterior proliferação de microrganismo. Nas partes brancas não há condensação.

Mesmo em climas tropicais, onde os problemas de condensação são menos significativos, Sato et. al. (2002) apresenta um caso em São Paulo onde sua ocorrência nas primeiras horas da manhã foi responsável pelo intenso crescimento de microrganismos e escurecimento de painéis pré-fabricados (Figura 1-6).

Apesar de seu grande potencial, as pesquisas que utilizam essa tecnologia buscam aumentar a eficiência energética das edificações e a redução das ilhas de calor (do inglês heat island) nas grandes cidades (Doulos et. al., 2004) e estão focadas nas tintas (Syfenna et. al., 2006) e em produtos para telhados (Akbari et. al., 2003).

Neste mesmo sentido, foi desenvolvido o trabalho de mestrado na Escola Politécnica da Universidade de São Paulo de autoria de Paula Ikematsu intitulado "Estudo da Refletância e sua Influência no Comportamento Térmico de Tintas Refletivas e 
Convencionais de Cores Correspondentes", sob a orientação da Prof. Dra. Kai Loh, defendido no ano de 2007.

Um dos pontos negativos desta técnica, para a prevenção de manchas em edifícios, é que ela não altera a relação entre a água e os materiais porosos, sendo útil apenas quando são utilizados sistemas de isolamento térmico nas edificações, quando o fenômeno de condensação ocorre com grande intensidade e frequência.

Dessa forma, essa técnica não é indicada para a redução de manchas nas vedações externas das edificações típicas no Brasil.

\subsubsection{Fotocatâlise}

A fotocatálise é um processo eletroquímico capaz de acelerar as reações de oxidação de substâncias orgânicas pela incidência de energia (Irie; Hashimoto, 2005). Vem sendo largamente pesquisada para o desenvolvimento de superfícies com propriedades anti-bactericidas, despoluidoras (do inglês de-pollution) e autolimpantes, tanto nos materiais não-porosos - como vidros, placas cerâmicas e metais -, como nos porosos (Valeé et. al., 2004; Pepe et. al., 2004).

De acordo com Parkin et. al. (2005), seu princípio de atuação consiste na transformação do material em super-hidrofílico fazendo com que surja uma lâmina de água na superfície capaz de eliminar as partículas que estejam aderidas na sua superfície (Figura 1- 7). Por não haver consumo de material durante este processo, superfícies com essas propriedades possuem, potencialmente, uma grande durabilidade (Hashimoto et. al., 2005).

Os materiais que apresentam esta propriedade são os semi-condutores sendo que o dióxido de titânio, principalmente o anatásio, vêm sendo o mais utilizado porque possui grande reservas em todo o mundo.

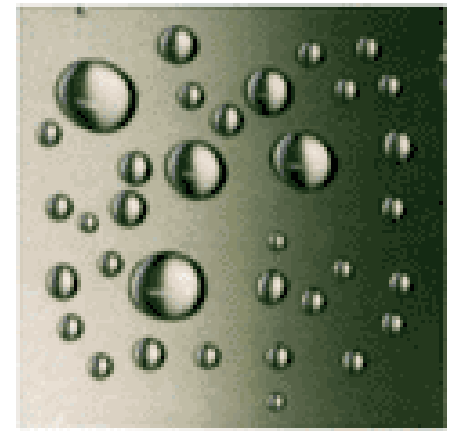

Antes do UV

(Gotas de água)

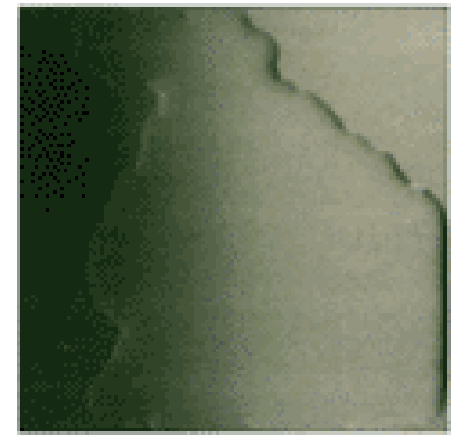

Depois do UV

(Láminas de água)

Figura 1- 7: Diferenças entre a forma de deposição da água em superfície fotoativadas pela ação do UV (http://www.greenquesttek.com/Photocatalyst.html).

\subsection{Anälise}

Com base na revisão bibliográfica realizada, constata-se que existem várias técnicas disponíveis com potencial de reduzir a proliferação de microrganismos e a deposição 
de poluentes por meio da modificação das propriedades superficiais dos materiais de construção.

Destas, apenas as aqui denominadas por hidrofugação e fotocatálise vêm sendo utilizadas para a prevenção da alteração de cor das vedações externas dos edifícios, apesar de possuírem princípios de atuação opostos. A primeira baseia-se na hipótese de que o conteúdo de umidade dos materiais de construção deva ser reduzir, por meio da repelência à água; enquanto que a segunda utiliza a água para a retirada dos agentes de alteração de cor aderidos aos edifícios.

Apesar disso, essas duas técnicas apresentam propriedades complementares que podem ser adequadamente utilizadas na criação de superfícies auto-limpantes, pois inibem a ação da água, que exerce grande influência nos materiais de construção silicosos e porosos, e, ao mesmo tempo, utilizam-se do efeito de arraste de partículas para limpeza espontânea da edificação.

\subsection{Hipótese e Objetivos}

Partindo-se do princípio de que é na etapa de concepção que as adequações são mais fáceis e efetivas de serem implantadas no processo de projeto de edifício; com consciência de que o desempenho das vedações externas é dependente do comportamento de todo o edifício; que a água se constitui em um importante agente gerador de manchas e, muitas vezes, a maior responsável pela sua configuração; e que as edificações devem se tornar um agente ativo na sustentabilidade do ambiente construído, estabelece-se como hipótese geral para a tese:

Um material de construção silicoso e poroso aplicado nas
vedações externas dos edifícios que apresente comportamento
hidrofóbico e com propriedades fotocatalíticas é efetiva
estratégia para a prevenção de manchas.

Assim, para testar esta hipótese é possível estabelecer que o objetivo principal desta tese é desenvolver um método capaz de inibir/reduzir o surgimento de manchas nas vedações externas dos edifícios causadas pela proliferação de microrganismos e pela deposição de poluentes atmosféricos.

Este método é destinado aos materiais de construção porosos e silicosos, quais sejam: argamassas de revestimento, telhas de fibrocimento sem amianto, cerâmica e placas de granito.

\subsection{Estratégia para Desenvolvimento da Tese}

O desenvolvimento desta tese foi realizado de maneira experimental e em escala laboratorial. Trata-se de uma pesquisa predominantemente quantitativa; entretanto aspectos qualitativos, identificados durante os experimentos, também são importantes fontes de informação. Além disso, por ter sido desenvolvido de maneira sequencial, os resultados de uma etapa servem de subsídios para a etapa seguinte. 
Este método de pesquisa foi escolhido porque possibilita a manipulação de diversas variáveis de forma simultânea e fornece os resultados esperados com a agilidade e a confiabilidade necessárias a uma tese de doutorado.

Para que seja mais fácil e rapidamente aplicável na construção civil, o método deve atender os seguintes pré-requisitos:

1) ser aplicado como pós-tratamento;

2) não influenciar nas propriedades estéticas do substrato (ser transparente);

3) não sofrer desprendimento quando exposto ao longo de sua vida útil (boa aderência e durabilidade aos substratos silicosos e porosos);

4) reduzir/inibir a proliferação de microorganismos;

5) reduzir/inibir a deposição de partículas de poluição.

Para tal, idealizou-se que a existência da camada com propriedades fotocatalíticas (oxidante e hidrofílica) imediatamente precedida por uma hidrofóbica (Figura 1- 8) possui elevado potencial, pois minimiza a ação da água no interior dos materiais de construção e, consequentemente, o crescimento de microorganismos; e reduz a adesão de poluentes atmosféricos, como consequência da elevada tensão superficial das superfícies hidrofílicas.

Uma superfície com essa configuração é inovadora e, por isso, atende aos requisitos de uma tese de doutorado.

Como modus operandi, esta tese utilizou-se de produtos à base de silicone para a formação da camada hidrofóbica, e o dióxido do titânio foto-ativado para a camada hidrofílica. A união idealizada dos dois produtos está representada na Figura 1- 9.

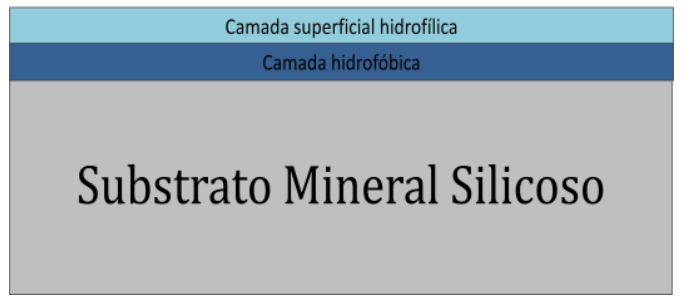

Figura 1- 8: Hipótese de alteração das propriedades superficiais para minimização da alteração de cor de materiais de construção silicosos e porosos.

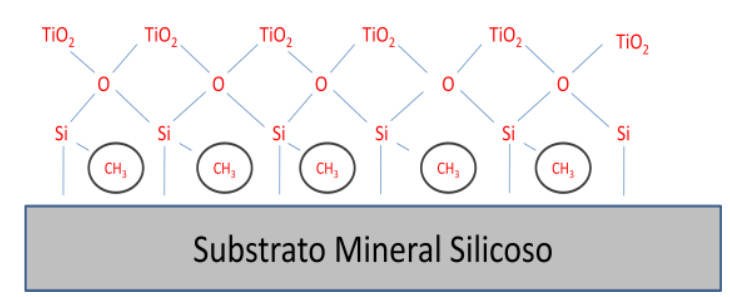

Figura 1- 9: Hipótese da união de produtos com propriedades fotocatalíticas com hidrofugantes à base de silicone para alteração das propriedades superficiais dos materiais de construção silicosos e porosos.

Para viabilizar e testar essa proposta, desenvolveu-se um programa laboratorial composto três etapas e suportadas pela aplicação de diversas técnicas laboratoriais como: Microscopia Eletrônica de Varredura (MEV), Espectroscopia de Infravermelhos por Transformada de Fourier (FTIR), ângulo de contato, análise e tratamento de imagens, entre outras. 
A descrição dos métodos experimentais utilizados em cada das etapas será realizada nos seus capítulos específicos.

\subsection{Estrutura da Tese}

Por se tratar de um trabalho inovador e pouco usual na Engenharia Civil, esta tese está estruturada em três grandes partes.

A primeira, constituída pelos Capítulos 1, 2 e 3, aborda a revisão bibliográfica; a segunda composta pelos Capítulos 4 e 5 cujo objetivo é avaliar as alternativas para se obter uma superfície com propriedades auto-limpantes; e a terceira, formada pelos Capítulos 6 e 7, que visa comprovar a eficiência do método desenvolvido e tecer as conclusões finais do trabalho.

No Capítulo 1 faz-se um apanhado geral sobre o tema de pesquisa, elabora-se a hipótese e os objetivos do trabalho e destaca-se a estrutura proposta para a tese.

Os dois capítulos seguintes, segundo e terceiro, são destinados a uma profunda revisão bibliográfica sobre os temas hidrofugação e fotocatálise, fundamentais para o desenvolvimento deste trabalho.

O Capítulo 4 avalia a viabilidade de se produzir uma superfície com as propriedades propostas na hipótese experimental por meio de profundas avaliações microestruturais.

O quinto capítulo avalia a eficiência do método proposto em reduzir a intensidade/surgimento de manchas nos diversos materiais de construção utilizados como objeto de estudo desta tese.

Finalmente o Capítulo 6 apresenta as considerações finais e as sugestões para trabalhos futuros. 


\section{CAPÍTULO II}

\section{Hidrofugante nos Materiais de}

\section{Construção Porosos}

\section{Introdução}

A água exerce importante influência nas propriedades dos materiais de construção silicosos e porosos, reduzindo seu desempenho termo-acústico e facilitando o surgimento de manchas. Trata-se de uma molécula polar com diâmetro de 0,9A e que a temperatura ambiente possui tensão superficial ${ }^{3}$ de $73 \mathrm{mN} / \mathrm{m}$ (Merouani, 1987).

As principais fontes de água em edifícios são: a chuva, o solo (umidade ascendente), a ocupação interna (humanos e equipamentos), a água de construção e a umidade do ar. Sendo que para cada uma dessas apresenta um perfil de armazenamento característico no edifício (Kunzel et. al., 2002).

Quando água está na forma de vapor, a transferência de umidade para os materiais de construção se dá por difusão seguido de adsorção física e condensação capilar (Figura 2-1); quando líquida (chuva, por exemplo), o fenômeno de capilaridade é quem predomina ${ }^{4}$.

Apesar de atuarem simultaneamente, o dois fenômenos apresentam importantes diferenças, sendo que as principais são:

a) tempo: a capilaridade age de maneira mais rápida, conseguindo saturar os materiais porosos em poucas horas; já na difusão levam-se meses ou até anos para se conseguir o equilíbrio (Fernandes, 1990; Mendes, 1997; Janz; Johannnesson, 2001)

b) quantidade de áqua: o fenômeno de difusão só possibilita condensação de água nos poros com pequenas dimensões (aproximadamente $0,1 \mu \mathrm{m}$ para uma umidade de $99 \%$ e um ângulo de contato de $0^{\circ}$, com base na equação

\footnotetext{
${ }^{3} \mathrm{Na}$ Física, a tensão superficial é um efeito que ocorre na camada superficial de um líquido que leva a sua superfície a se comportar como uma membrana elástica (http://pt.wikipedia.org, acessado no dia 04/08/2009).

${ }^{4}$ O fenômeno de transporte de massa nos materiais porosos não-tratados já foi objeto de trabalhos como Fernandes (1990) e Sato (1998). Por isso, aqui serão destacados apenas alguns pontos que servirão de base para discussão da hipótese apresentada no capítulo 1.
} 
de Kevin-Laplace ${ }^{5}$ ). Por isso, mesmo em altíssimas umidades relativas, boa parte dos poros do material de construção encontra-se não-saturados. Fernandes (1990), por exemplo, avaliou que a difusão só consegue produzir um teor de umidade de $6 \%$ para uma argamassa com porosidade de $31 \%$, acrescentando ainda que apenas $5 \%$ estariam disponíveis na forma de água condensada, pois o restante está adsorvido nas paredes dos poros. Grunewald (2007) apresenta resultados semelhantes para outros materiais de construção.

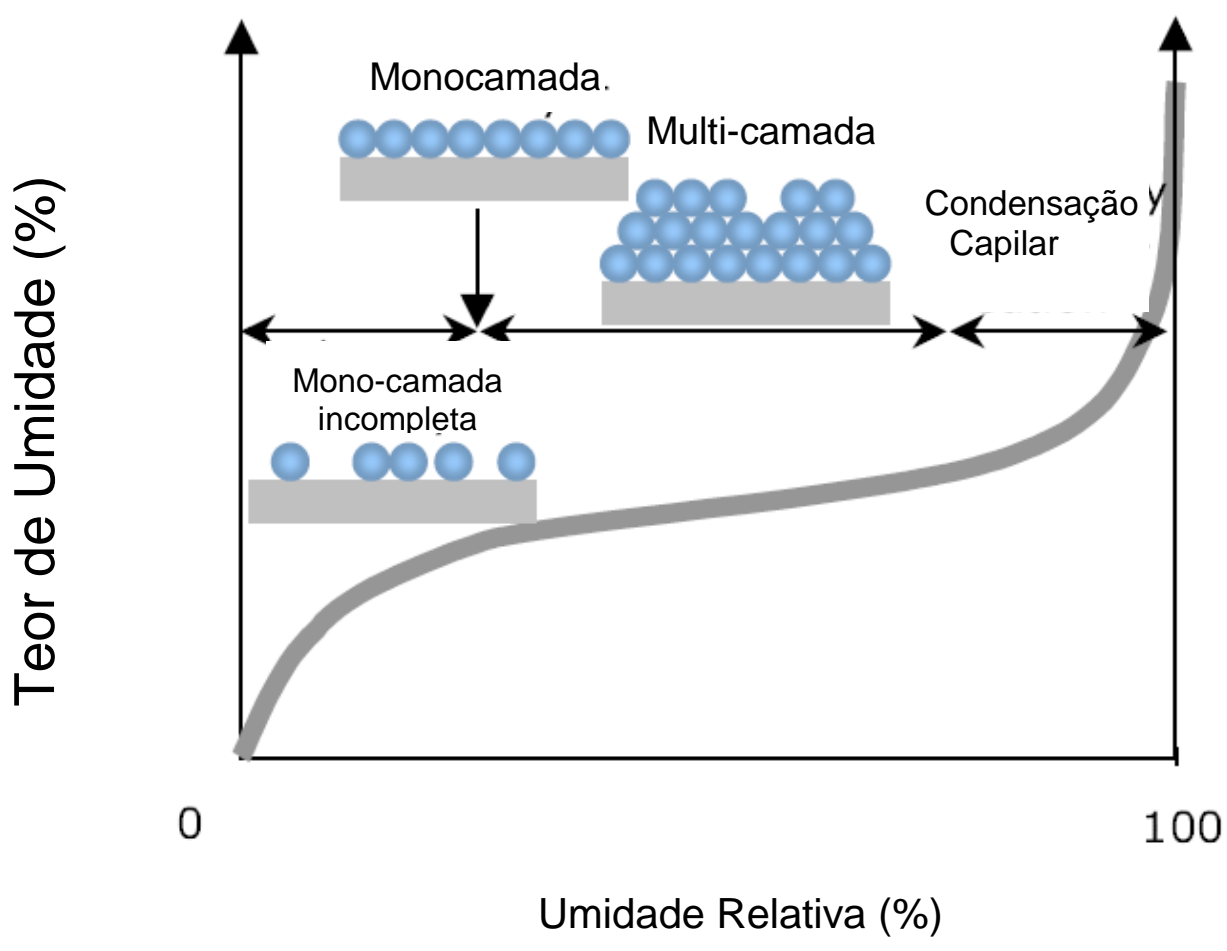

Figura 2- 1: Isoterma de adsorção ilustrativa de um material poroso. Baseado em Moller (2003).

${ }^{5}$ Equação de Kevin-Laplace: $r=\frac{-2 * \sigma_{w} * \cos \theta * M_{w}}{\ln \varphi * R * T * \rho_{w}}$ equação 2.1

$R$ é o raio abaixo do qual há condensação $(\mathrm{m})$;

$M_{w}$ é a massa molar da água $(\mathrm{Kg} / \mathrm{mol})$;

$\sigma_{w}$ é a tensão superficial da água $(\mathrm{N} / \mathrm{m})$;

$\theta$ é o ângulo de contacto entre a água e a superfície do sólido;

$\rho_{w}$ é a densidade da água $\left(\mathrm{Kg} / \mathrm{m}^{3}\right)$;

$\mathrm{R}$ é a constante universal dos gases ( $\mathrm{J} / \mathrm{mol} \mathrm{K})$;

T é a temperatura (k);

$\ln \varphi$ é o logaritmo natural da umidade relativa $(0<U R<1)$. 
A capacidade e cinética da absorção de água nos materiais silicosos e porosos dependem de:

a) quantidade e dimensão dos poros;

b) estrutura de poros;

c) molhabilidade da superfície.

As duas primeiras questões estão intimamente ligadas, ou seja, quanto maior a quantidade, a dimensão e a conectividade entre os poros de um material, maior é a sua capacidade de absorção de água.

Sua molhabilidade está ligada à energia livre de superfície, e é caracterizada pelo ângulo de contato formado entre o sólido e a água., sendo o seu valor o resultado do equilíbrio entre os vetores de energia livre que atuam simultaneamente na interface sólido-líquido-gás. Genericamente, uma superfície é classificada como hidrofóbica quando o ângulo for superior a $90^{\circ}$, e como hidrofílica quando for inferior a este valor.

Quando ocorrem apenas fenômenos físicos, um sólido é molhado pela água quando a sua energia livre de superfície for superior, sendo esse fenômeno tão mais importante quanto maior for essa diferença. A maior molhabilidade é caracterizada por reduções no ângulo de contato (Luiz et. al., 2008).

A medição da tensão superficial de um sólido não é das mais fáceis de ser obtida, mas é possível generalizar que (Baer, 1964 apud Moller, 2003):

- os líquidos, com exceção dos metálicos, apresentam uma tensão superficial inferior a $100 \mathrm{mN} / \mathrm{m}$. A água, por exemplo, tem uma tensão superficial de $73 \mathrm{mN} / \mathrm{m}$;

- os sólidos "moles", como ceras e outros polímeros orgânicos, incluído os silicones, têm uma energia livre de superfície inferior a $50 \mathrm{mN} / \mathrm{m}$. A glicerina e o silicone, por exemplo, possuem uma tensão superficial de $24 \mathrm{mN} / \mathrm{m}$ e $18 \mathrm{~m} \mathrm{~N} / \mathrm{m}$, respectivamente;

- os sólidos "duros", como os materiais cerâmicos e metais, possuem energia livre de superfície entre 500 e $5000 \mathrm{mN} / \mathrm{m}$. Quanto mais rígidos e quanto maior for a temperatura de fusão de uma material, maior é a sua energia livre de superfície.

Desta forma, os materiais inorgânicos e porosos, que são classificados como cerâmicos, apresentarem características hidrofílicas (maior tensão superficial do que a água), enquanto que os polímeros são hidrofóbicos, pois possuem menor tensão superficial do que a água.

\subsection{Hidrofugantes}

A prevenção da penetração de água nas construções vem sendo tentada a longo tempo, havendo registro da aplicação de óleos e ceras para a proteção das rochas em templos gregos e romanos (Charola, 1995). 
Existem diversas maneiras de se evitar a penetração de água nos materiais porosos, que podem ser genericamente classificadas em: (a) modificador da tensão superficial das paredes dos poros (b) bloqueador de poros e (c) formador de película superficial (Figura 2-2). Dessas, a primeira vem sendo a mais utilizada, pois consegue reduzir a entrada de água e causa os menores impactos na permeabilidade ao vapor dos materiais de construção (Kus, 2002).

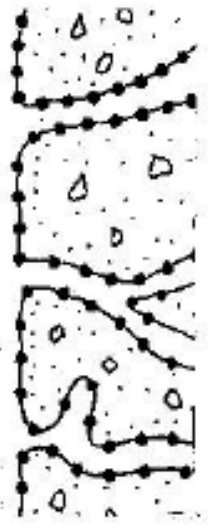

(a)

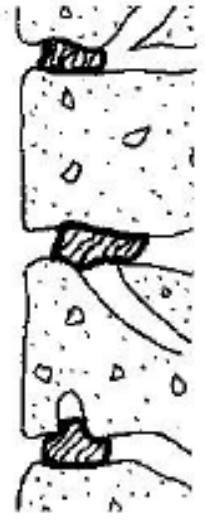

(b)

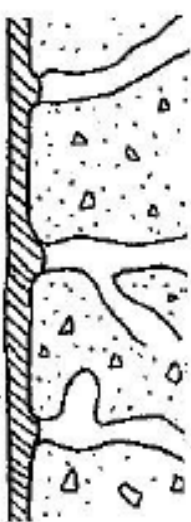

(c)

Figura 2- 2: Possíveis formas de ação dos produtos hidrofugantes nos materiais de construção porosos. (a) alteração da tensão superficial dos poros; (b) bloqueador dos poros; e (c) formador de película. Kus (2002).

Diversos tipos de hidrofugantes são utilizados na construção civil sendo que os mais utilizados são os produtos à base de silicone.

Os silicones são obtidos por meio do processo denominado Rochow Process, onde o primeiro estágio é a redução do quartzo em silício metálico, seguido de reações com cloreto de metila (que é resultado da reação do ácido clorídrico com o metanol) e água, (O'Lenick, 2000) ${ }^{6}$. Como resultado, tem-se um composto denominado por polidimetilsiloxano - PDMS, cuja formula genérica é $\mathrm{R}_{2} \mathrm{SiO}$, onde o radical $\mathrm{R}$ representa o radical apolar (Dow Corning, s.d).

Lork (2003) apresenta que na química dos silicones, existem quatro possíveis ligações do tipo siloxano (Figura 2-3), sendo que a tetrafuncional, segundo Mayers

\footnotetext{
${ }^{6}$ A sequência de reações pode ser assim resumida (O'lenick, 2000):

$\mathrm{SiO}_{2}+\mathrm{C} \stackrel{1700^{\circ} \mathrm{C}}{\longrightarrow} \mathrm{Si}+\mathrm{CO} \quad \ldots \quad$ Produção do silício metálico

$2 \mathrm{CH}_{3} \mathrm{Cl}+\mathrm{Si} \stackrel{300^{\circ} \mathrm{C}}{\longrightarrow}\left(\mathrm{CH}_{3}\right)_{2} \mathrm{SiCl}_{2} \quad \ldots$ Produção do clorosilano -0 principal produto é Dimetilclorosilano

$\left(\mathrm{CH}_{3}\right)_{2} \mathrm{SiCl}_{2}+2 \mathrm{H}_{2} \mathrm{O} \rightarrow \mathrm{HCL}+\left(\mathrm{CH}_{3}\right) \mathrm{Si}(\mathrm{OH})_{2} \quad \ldots \quad$ Hidrólise do clorosilano

$n\left(\mathrm{CH}_{3}\right)_{2} \mathrm{Si}(\mathrm{OH})_{2} \rightarrow \mathrm{H}_{2} \mathrm{O}+\mathrm{HO}-\left(\mathrm{Si}_{(}\left(\mathrm{CH}_{3}\right)_{2}-\mathrm{O}\right)_{n} \mathrm{H}$... Desidratação e produção de silanol (dimetilconols) e cyclothione
} 
(1998), só entra neste grupo porque forma ligações cruzadas entre macromoléculas, uma vez que não há ligações entre o silício e o radical orgânico.

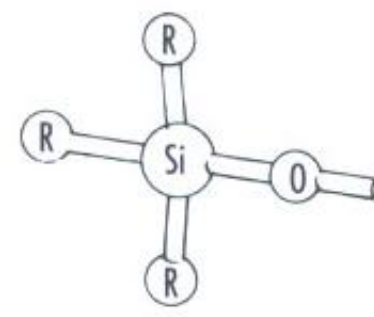

Monofuncional

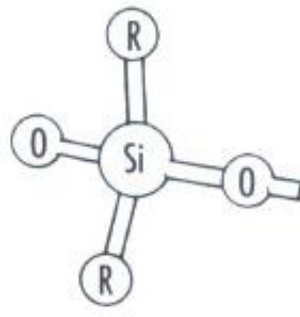

Bifuncional

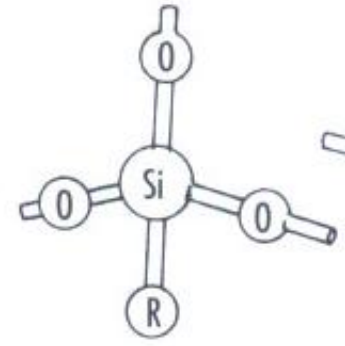

Trifuncional

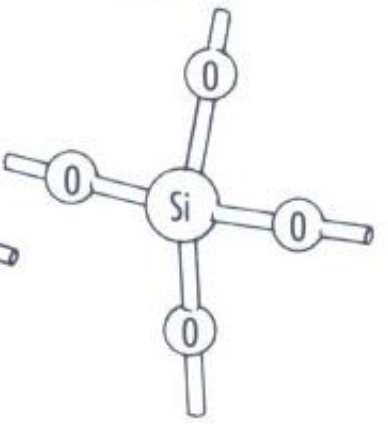

Tetrafuncional

Figura 2- 3: llustrações dos tipos de siloxanos existentes. Fonte: Mayers (1998)

Mayer (1998) descreve que os monofuncionais, por possuírem apenas um oxigênio para se ligar ao outro silício, são utilizados como final de cadeia; os bifuncionais, que possuem dois oxigênios, podem se polimerizar em forma linear e de anel; e os trifuncionais formam cadeias tridimensionais por conta das ligações cruzadas.

Os silicones são utilizados como material hidrofugante porque sua parte inorgânica possui boa estabilidade aos agentes de degradação (as ligações $\mathrm{Si}-\mathrm{O}-\mathrm{Si}$, possuem energia de ligação de $452 \mathrm{KJ} / \mathrm{mol})^{7}$, por conseguirem uma boa adesão química a diferentes substratos, devido aos compostos, gerados durante a polimerização: $\mathrm{SiOH}$ (silanol), $\mathrm{SiH}, \mathrm{SiOCH}_{3}$ e $\mathrm{SIOC}_{2} \mathrm{H}_{5}$; e porque os radicais apolares possuem elevada repelência à água.

Diversos tipos de radicais são usados em hidrofugantes à base de silicone (Tabela 1 , sendo que os mais comuns, para os materiais de construção silicosos e porosos, são o octil e o metil.

\footnotetext{
${ }^{7}$ A energia de ligação do Si - C é de $318 \mathrm{~kJ} / \mathrm{mol}$ (dow corning, sd.)
} 
Tabela 1: Radicais orgânicos usados nos hidrofugantes à base de silicone (Charola, 1995).

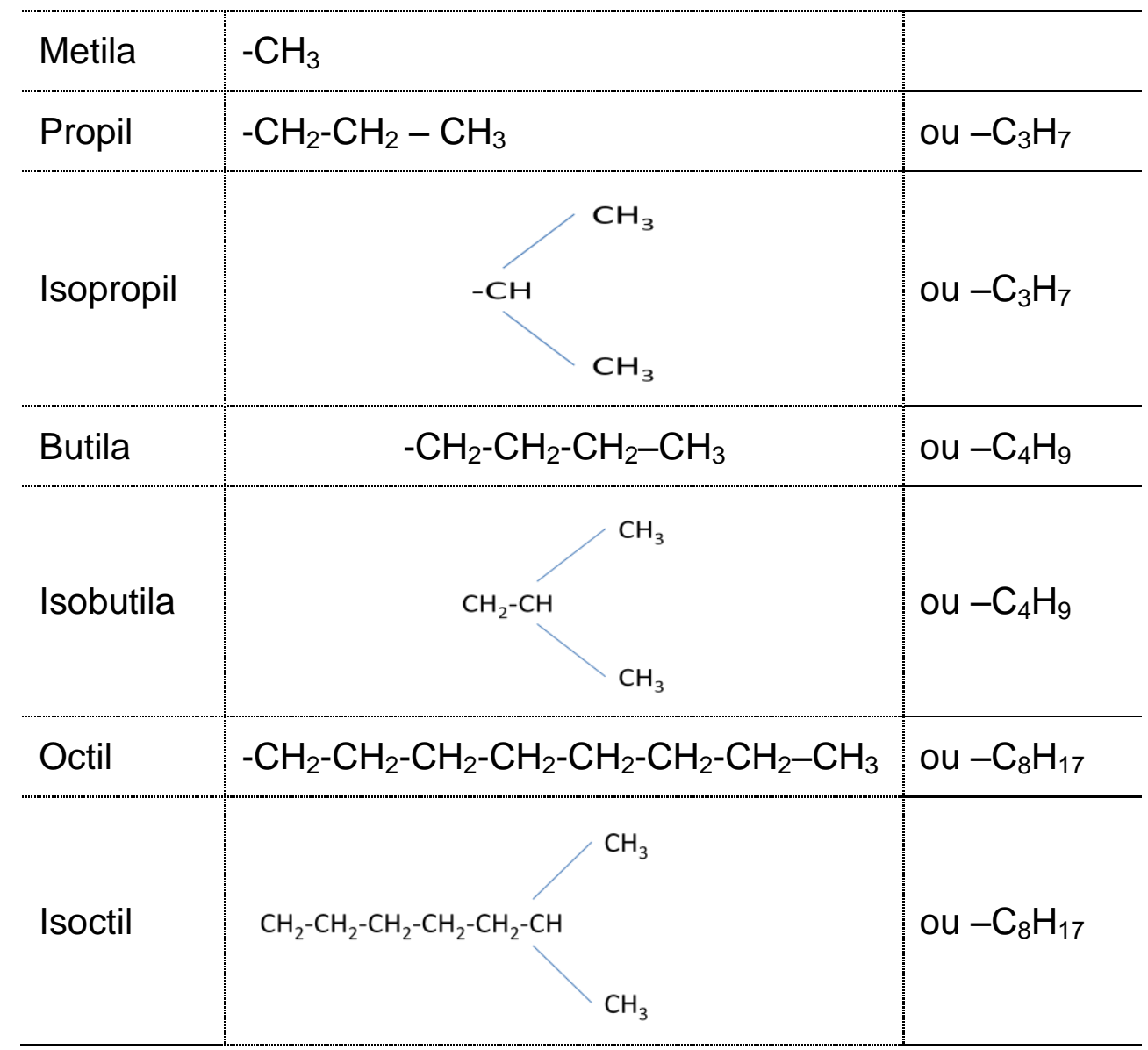

Para que ocorra a adesão dos silicones a substratos inorgânicos uma sequência de reações de hidrólise e condensação deve acontecer (Charola, 1995). Como consequência tem-se a formação de uma ligação forte de caráter eminentemente iônico. Além disso, observa-se o alinhamento dos radicais orgânicos, como consequência da sua menor tensão superficial e da baixa energia de rotação entre o silício e o carbono (Dow Corning, sd.). A Figura 2- 4 ilustra essas reações. 
1. Hidrólise

2. Condensação
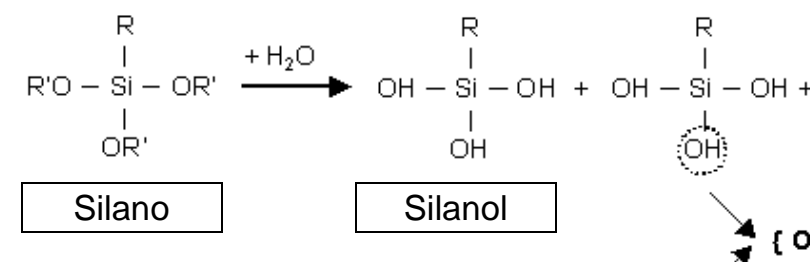

$\left\{\mathrm{OH}+\mathrm{OH}=\mathrm{H}_{2} \mathrm{O}+(-\mathrm{O}-)\right.$

3. Reação
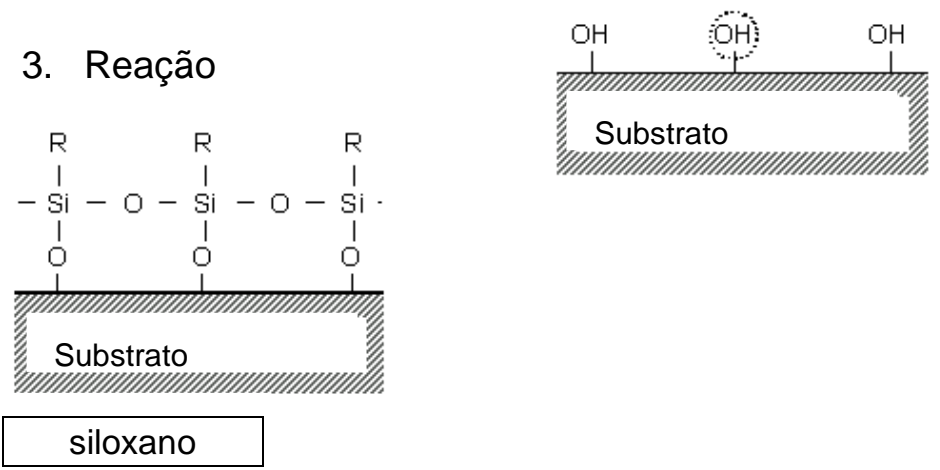

Figura 2- 4: Ilustração do processo de adesão de um silano a um substrato silicoso, onde $\mathrm{R}$ = radical orgânico e OR'= grupo alcoxi. Fonte: Kus (2002).

Os três principais produtos à base de silicone utilizados como hidrofugantes na construção civil são: Metil-siliconato, silano e siloxano.

a) Metil-siliconatos: produtos provenientes da adição de metal alcalino à uma solução de metil-silano, com o objetivo de aumentar a estabilidade, solubilidade e baratear o seu custo final (Figura 2- 5). É predominantemente quando a aplicação do produto se dá em escala industrial (indoor) e em materiais de baixo valor agregado, como telhas cerâmicas e fibrocimentos.

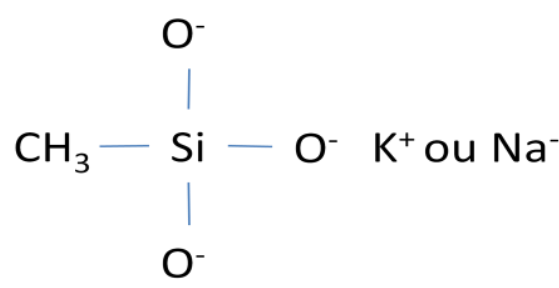

Figura 2- 5: Estrutura química dos Siliconatos (Selley et. al. 2006).

Quando aplicados como pós-tratamentos, essa classe de produto promove uma hidro-repelência apenas intermediária e reagem de maneira lenta aos substratos de produtos alcalinos, como as argamassas e os fibrocimentos (Mcgettigan, 1995). Podem, ainda, causar manchas esbranquiçadas se for aplicado sobre substratos saturados.

b) Silanos: são os mais simples dos silicones, onde monômeros trifuncionais apresentam uma ligação com um radical apolar, responsável pela hidrorepelência, e três grupos alcoxi (Figura 2- 6). 


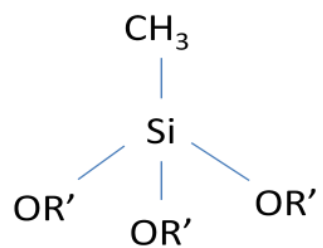

Figura 2- 6: Estrutura química do silanos (Mayers, 1998).

Esse tipo de material caracteriza-se por ser transparente, não formar filme, possuir baixa viscosidade e o menor tamanho de molécula dentre os derivados de silicone (entre 10 a $25 \AA$, segundo Kus, 2002).

Um ponto negativo destes produtos é que os alcoóis existentes na molécula são volatizados durante a policondensação, fazendo com que uma importante parcela do material não seja aproveitada (em torno de $40 \%$ de sua massa inicial). Outro ponto importante é que, sob condições adversas de cura, como em altas temperaturas e vento, demandam um longo tempo para polimerização.

c) Siloxanos: são formados por cadeias de três a oito átomos de silício, ligados por estruturas bifuncionais e trifuncionais (Mayers, 1998). Sua estrutura química é apresentada na Figura 2- 7.<smiles>[R7][Si]([R9])(C)O[Si]([R7])(C)O[Si]([R7])([R7])O</smiles>

Figura 2- 7: Estrutura química do Siloxano (Mayers, 1998).

Os siloxanos são transparentes, com um tamanho de molécula de 25 a $100 \AA$ (Kus, 2002) e com um menor conteúdo volátil do que os silanos.

Comparado aos silanos, os siloxanos possuem uma energia superficial cerca de $10 \%$, inferior, uma maior reatividade, e uma redução no tempo necessário para formação da superfície hidrofóbica.

Na prática, a maior parte dos produtos comerciais utilizados é formada pela mistura de silanos e siloxanos, sendo que para os granitos, que possuem poucos e pequenos poros, há uma predominância de silanos, enquanto que, em superfícies muito porosas, como as argamassas de revestimentos, os siloxanos predominam. 


\subsection{Ação dos Hidrofugantes nos Materiais Porosos}

O uso de hidrofugante altera a relação entre a água e o material poroso, pois provoca queda na tensão superficial do sólido, como consequente aumento do ângulo de contato, uma redução na absorção d'água e na adsorção de vapor (Figura 2- 8). Esse fenômeno é tanto mais importante quanto maior é a porosidade do substrato.
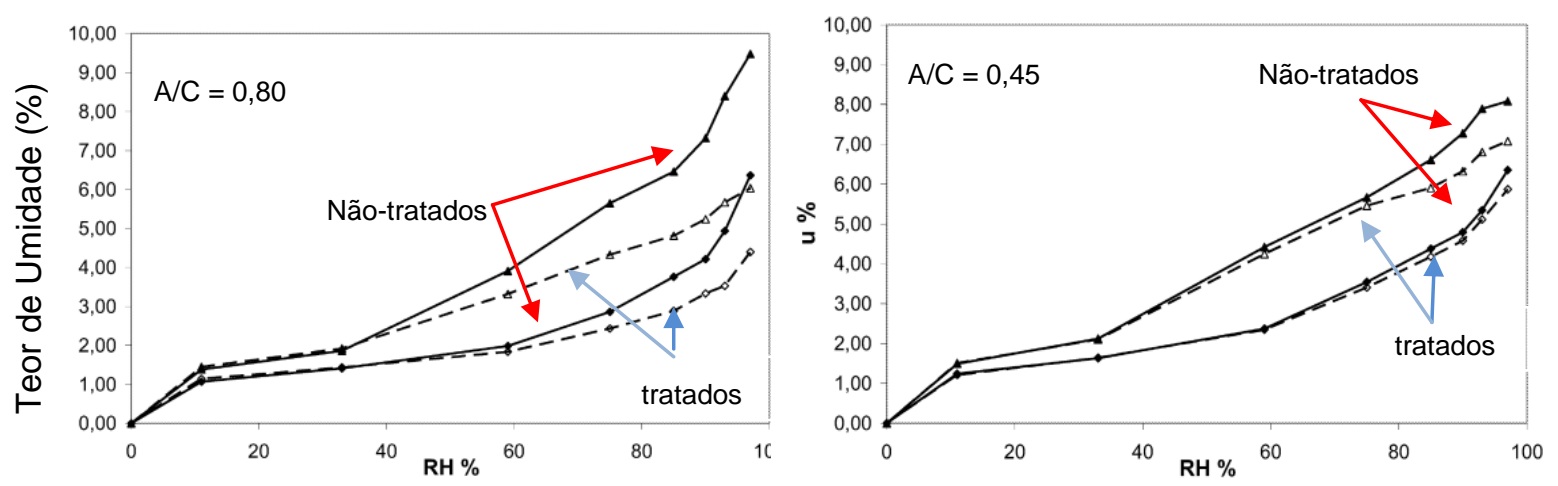

Figura 2- 8: Isotermas de adsorção/dessorção para concretos tratados e não tratados. Direta: relação água/cimento $=0,80$ e esquerda: relação água/cimento $=0,45^{8}$. Fonte: Johansson (2006).

Mesmo não atuando como bloqueador de poros, o uso de hidrofugantes causa importantes alterações na velocidade de secagem dos materiais de construção (Figura 2- 9), pois reduz os coeficientes de difusão de umidade e de capilaridade que se constituem nos principais fenômenos responsáveis por sua cinética (Kunzel, Kiebl, 1996; Lockington et. al., 2003, Pel, Landman, 2004 e Shahidzadej-Bonn et. al., 2007).

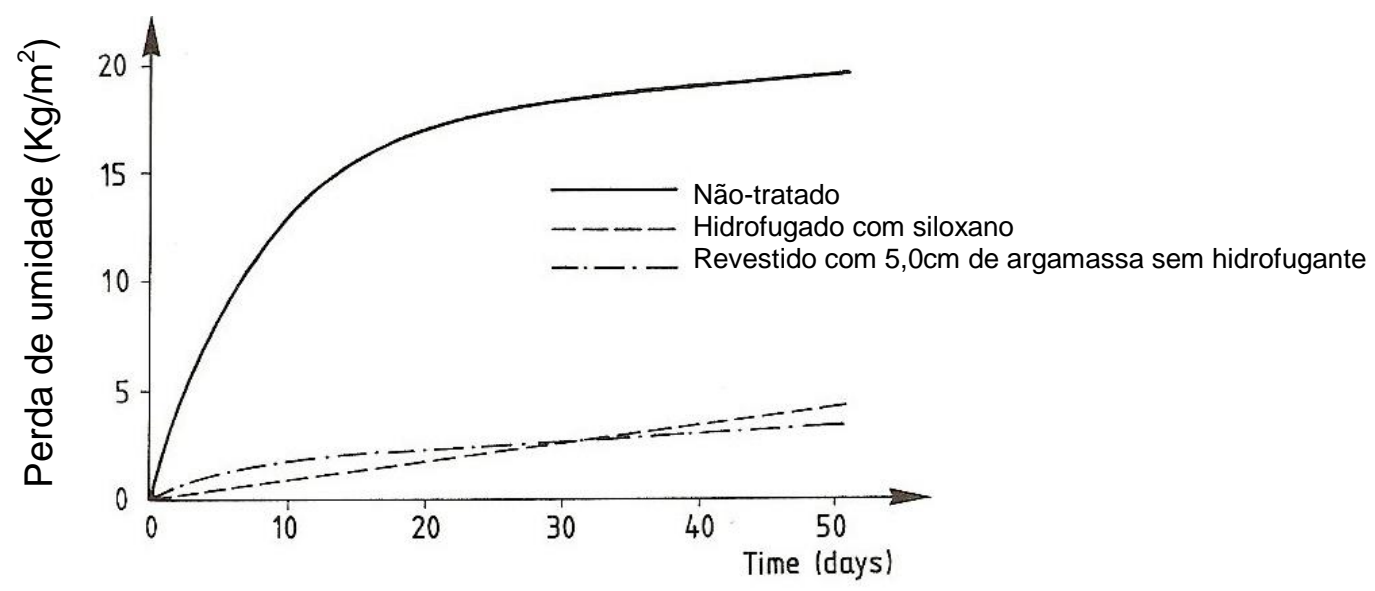

Figura 2- 9: Cinética de secagem de blocos cerâmicos. Fonte: (Sandin, 1996).

\footnotetext{
${ }^{8} \mathrm{Na}$ dessorção o conteúdo interno de umidade é maior do que na adsorção para uma mesma umidade relativa, como consequência do maior ângulo de contato entre a água e a superfície do sólido e pela existência de gargalos na estrutura porosa.
} 


\subsection{Fatores que Influenciam no Desempenho dos Hidrofugantes}

\subsubsection{Forma de Aplicaçã̃o}

As principais formas de aplicação dos produtos hidrofugantes são a adição à mistura, nos materiais cimentícios, e o pós-tratamento, que se usa em todos os tipos de materiais.

O mais tradicional é o segundo, pois tem a vantagem de não alterar, de maneira radical, os métodos construtivos empregados, não representar aumentos de custos vultosos, possuir um histórico de utilização e de ser compatível com diversos tipos de materiais.

O pós-tratamento pode ser aplicado por pintura, spray, gel ou creme para os materiais já em uso, e por imersão quando os produtos ainda se encontram em unidades industriais, como é o caso de telhas cerâmicas e pré-moldados. As grandes desvantagens do pós-tratamento é que ele acrescenta uma etapa no método construtivo, e que seu desempenho cai se surgirem fissuras superficiais posteriores (Kus, 2002).

A adição à mistura, por sua vez, também vem sendo utilizada na construção civil pois possibilita a introdução diferenciais competitivos a produtos tradicionais, como argamassas e fibrocimento. Além disso, esse método possui a vantagem de não acrescentar etapas no processo de produção e ter seu desempenho menos influenciado pelo surgimento de fissuras superficiais.

Ocorre, porém, que a adição a mistura pode provocar alterações nas propriedades reológicas das suspensões, tornando-as mais rígidas e com menor tempo de vida útil (Maranhão et. al., 2007 e Maranhão et. al., 2008). Além disso, pode influenciar no surgimento de eflorescência por motivos ainda não totalmente entendidos e que fogem ao escopo desta tese (Figura 2- 10); e ainda reduzir a resistência mecânica de produtos cimentícios por interferir na formação da matriz dos produtos hidratados.

Comparar o desempenho entre as diferentes formas de aplicação não é das tarefas mais fáceis, visto que há poucos trabalhos que focaram o tema. Para as argamassas de revestimento, Kus (2002) conclui que o pós-tratamento foi mais eficiente e apresentou menor intensidade de deterioração ao longo do envelhecimento natural; para os fibrocimentos, Selley et. al. (2006), apresenta resultados opostos. 


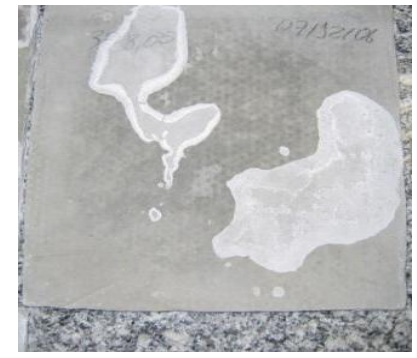

$0 \%$

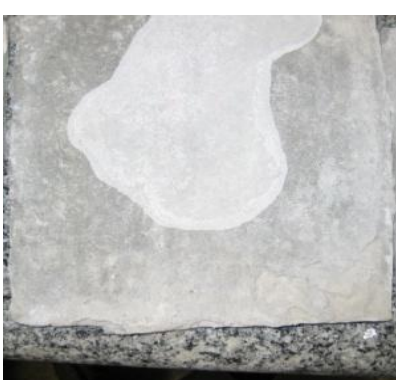

$0,25 \%$

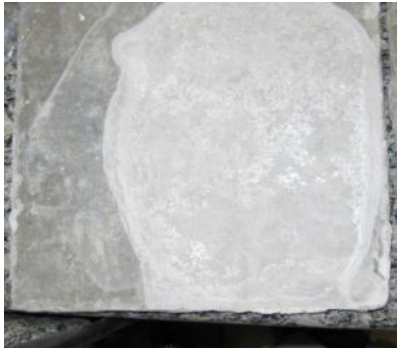

$0,50 \%$

Teor de Hidrofugante

Figura 2- 10: Influência do teor de um isoctilsilano adicionado à mistura no surgimento de eflorescências de fibrocimento (placas de $20 \mathrm{~cm} \times 20 \mathrm{~cm}$ ). Os teores referem-se à massa total de materiais secos. Fonte: arquivo pessoal do autor.

\subsubsection{Propriedades do Substrato Profundidade de Penetração do Hidrofugante}

De maneira geral, quanto maior a sucção e a porosidade do substrato, mais efetivo é o desempenho do hidrofugante em barrar a entrada de água. Portanto, profundidades de penetração elevadas são sempre buscadas.

Apesar disso, ainda não existe um consenso sobre um valor mínimo para a profundidade de penetração que garanta o desempenho em longo prazo de revestimentos. Para o caso de concreto, Gerdes; Meier (1998) sugerem que 6,0mm são o suficiente para combater os agentes de degradação e pequenas fissuras que por ventura possam surgir ao longo de sua vida útil.

A forma mais comum de se avaliar a profundidade de penetração do hidrofugante é por meio da diferença de cor após a pulverização de água de superfícies recém fraturadas (Figura 2-11). Trabalhos como os de Ricardo (1993) e Johansson (2006) propõem métodos não destrutivos.

Além da profundidade de penetração, o tipo de substrato irá influenciar na adesão do produto hidrofugante e no seu desempenho final. Isto porque alguns substratos não permitem a formação de ligações químicas entre o produto hidrofugante e seus óxidos, impossibilitando os processos de adesão.

Selley (2006) resume que os produtos à base de silicones apresentam:

- Excelente aderência: substrato silicosos (cerâmica, cimento e granito), quartzo, vidros, alumínio, cobre e óxidos de alumínio;

- Boa aderência: talco e óxidos inorgânicos (ex: $\mathrm{Fe}_{2} \mathrm{O}_{3}, \mathrm{TiO}_{2}, \mathrm{Cr}_{2} \mathrm{O}_{3}$ );

- Baixa aderência: níquel, zinco e carbonatos de cálcio $\left(\mathrm{CaCO}_{3}\right)$;

- Nenhuma: gesso, barita $\left(\mathrm{BaSO}_{4}\right)$, grafite e fuligem. 


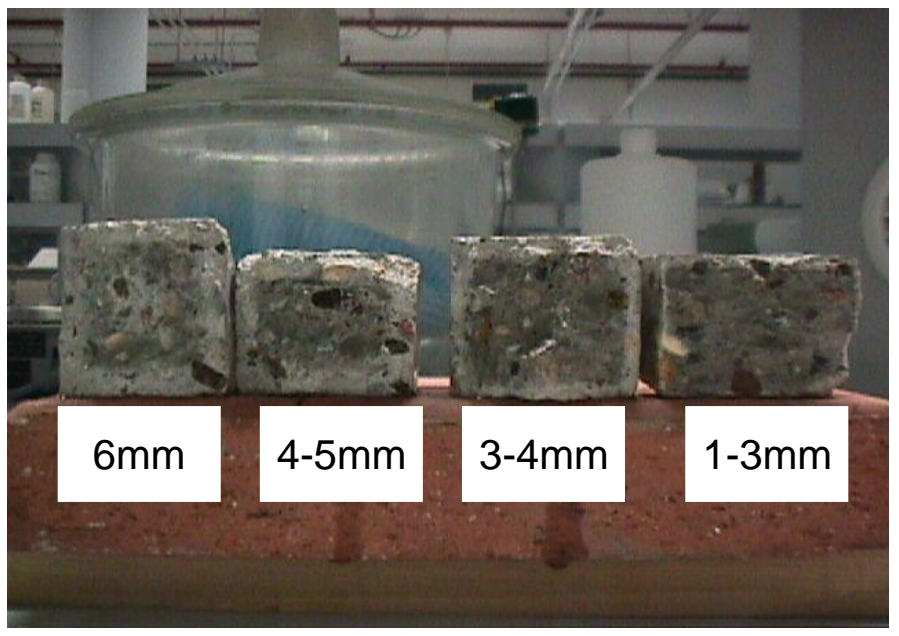

Figura 2- 11: Profundidade de penetração de um silano em concretos. Selley (2006).

\subsubsection{Teor de Materiais Ativos}

Quanto maior o teor de materiais ativos, maior a redução da absorção d'água provocada pelo hidrofugante, isso porque há uma maior quantidade de radicais apolares para recobrir os poros do substrato.

A forma mais comum de se manipular essa variável é aumentando a concentração do hidrofugante quando se vai fazer a diluição para a sua aplicação.

Ocorre, porém, que essas diluições podem alterar o perfil de penetração do hidrofugante no substrato, uma vez que quando concentrados, há uma maior e mais eficiente penetração do que quando aplicados de forma diluída (Figura 2-12).

Isto porque a água, por possuir menor viscosidade do que os hidrofugantes, são mais rapidamente succionada pelo poros da base, saturando-se e impedindo que 0 silicone possa penetrar no substrato.

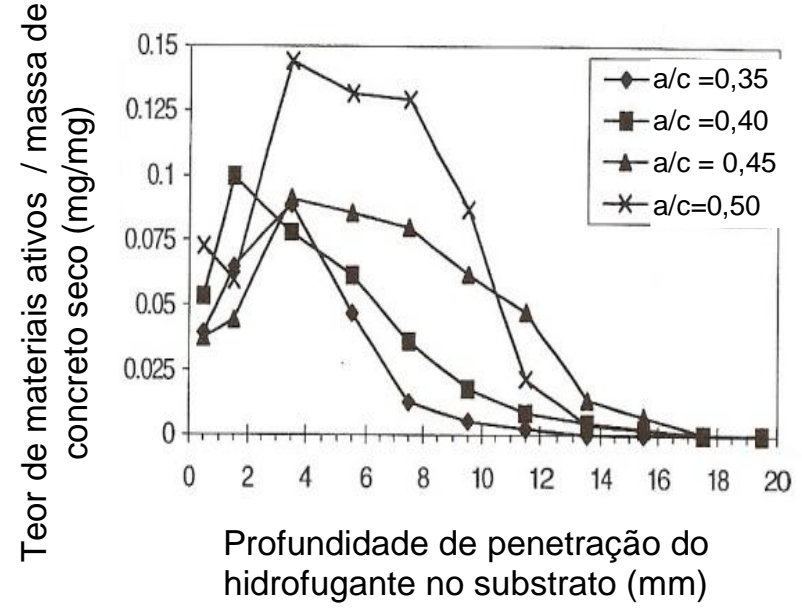

$100 \%$ silano

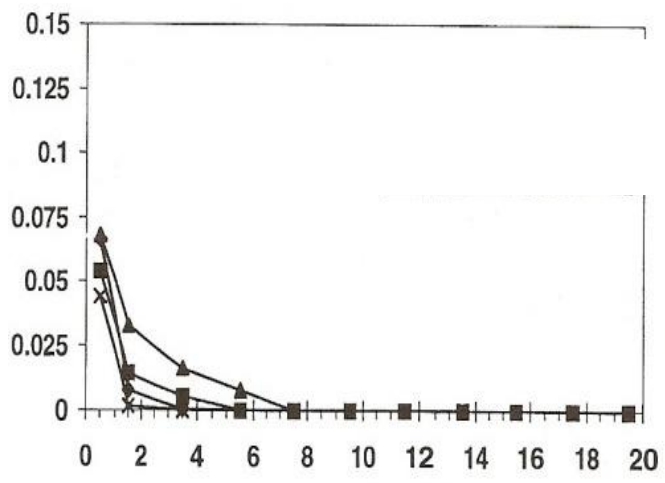

Profundidade de penetração do hidrofugante no substrato $(\mathrm{mm})$

Emulsão aquosa de silano

Figura 2- 12: Influência da porosidade na distribuição dos materiais ativos ao longo da espessura de substratos de concreto. Fonte: Gerdes et. al. (1998). 


\subsubsection{Presença de Fissuras}

A presença de fissuras posteriores a aplicação do hidrofugante pode comprometer todo o seu potencial em barrar a penetração de água, sendo esta influência tanto mais importante quanto maior a dimensão e a profundidade dessas fissuras (Sandin, 1996, Lunk;Wittmann, 1998 e Yokota et. al., 2008). Apesar de não existir um valor mínimo, a experiência tem mostrado que fissuras com dimensões superiores a $0,20 \mathrm{~mm}$ já diminuem o desempenho de produtos à base de silicone.

Como medida mitigadora, maiores profundidades de penetração do hidrofugante vêm se mostrando efetivas para minimizar o efeito das fissuras (Figura 2-13).
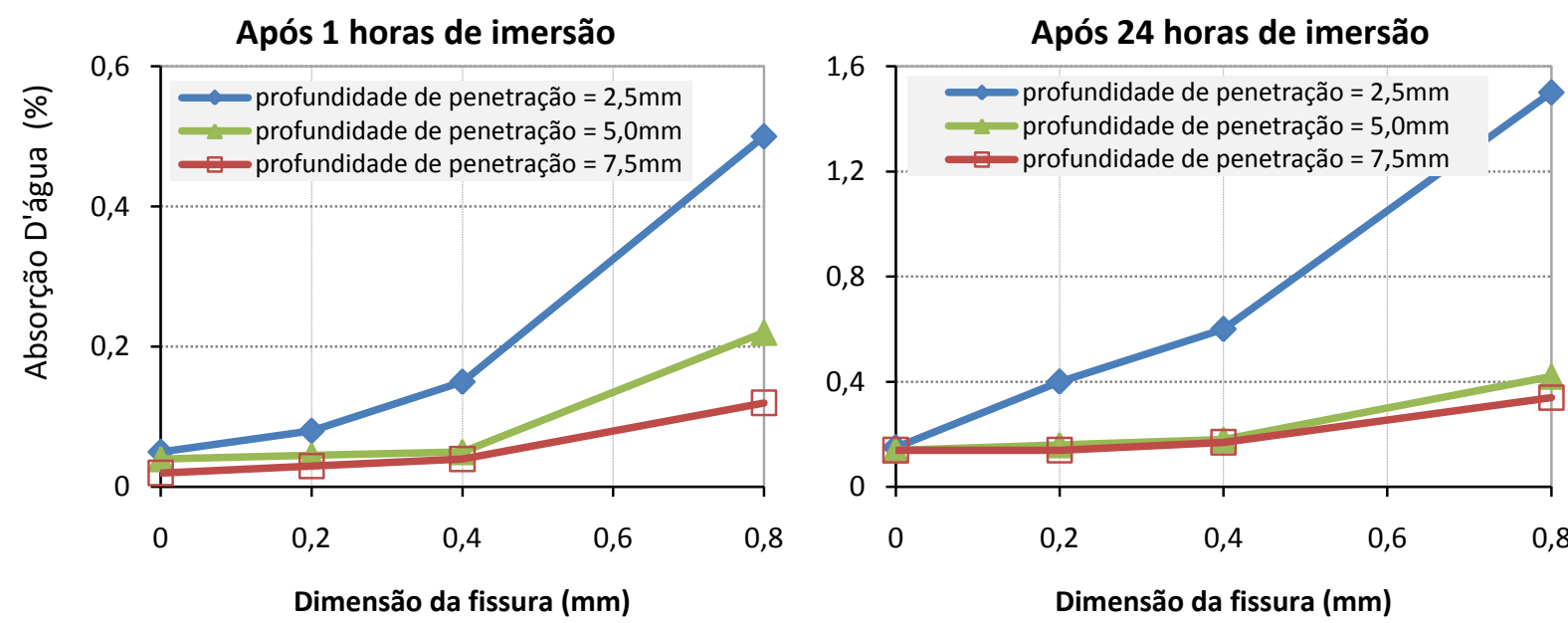

Figura 2- 13: Influência da dimensão da fissura no ganho de umidade de concretos hidrofugados após uma hora de imersão (a) e vinte quatro horas (b). Baseado em: Lunk; Wittmann (1998).

\subsection{Durabilidade}

Diversos trabalhos apresentam resultados sobre a durabilidade de sistemas hidrofugados, tanto àqueles submetidos a ciclos de envelhecimento acelerado, em escala laboratorial, quanto os acompanhados ao longo envelhecimento natural com exposições em vários sítios.

Um dos mais interessantes foi desenvolvido por Kus (2002) que, por meio de avaliações comparativas, de envelhecimento acelerado e natural na cidade de Gävle, Suécia, concluiu que os hidrofugantes aplicados como pós-tratamento continuam a reduzir a absorção d'água em mais de $50 \%$, quando comparado com amostras de referência, após 36 meses de monitoramento contínuo.

As duas principais causas de degradação de produtos à base de silicone são: quebra das ligações do radical orgânico pela ação do UV e hidrólise das ligações siloxano (O-Si-O). Este último fator é intensificado em $\mathrm{pH}$ altos, como os existente nos poros de produtos cimentícios. 
Para ambos os casos, há um consenso de que quanto maior for o radical orgânico do hidrofugante, maior será sua resistência à radiação UV e à ação do ataque alcalino. Isto é consequência direta de uma barreira física que os radicais apolares maiores formam e dificultam o acesso à matriz silicosa (Figura 2- 14). Desta forma, um produto com radical octil apresenta maior durabilidade do que um metil.

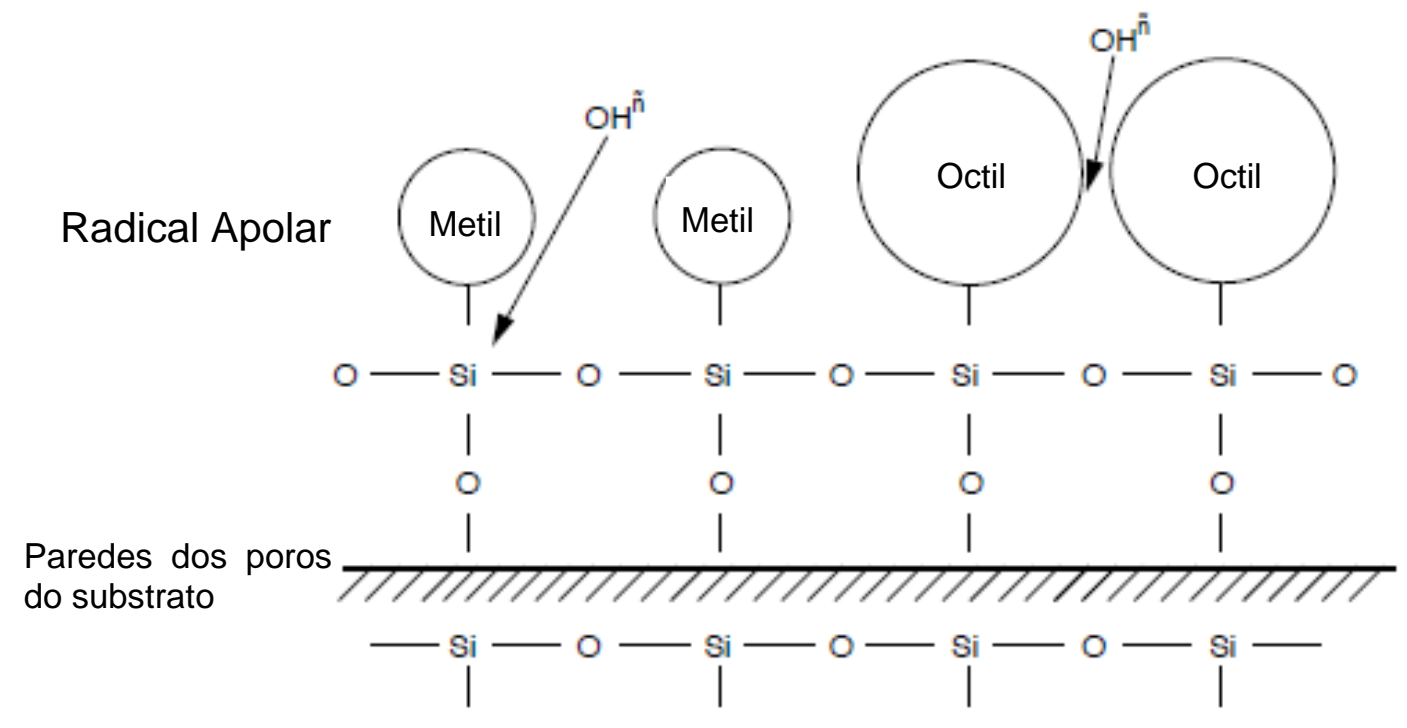

Figura 2- 14: Influência do tipo de radical apolar na proteção da matriz siloxano. (Basheer, Long, 1997).

\subsection{Influência dos Hidrofugantes no surgimento de Manchas}

O uso de hidrofugantes reduz a quantidade de água disponível no substrato e, potencialmente, as manchas causadas pela proliferação de microorganismos. Além disso, a tensão superficial dos produtos à base de silicone reduz a adesão de alguns tipos de microorganismos, como as bactérias (Figura 2-15).

Apesar disso, não conseguem impedir, completamente, o surgimento de manchas.

Isto porque seu caráter lipofílico (Biron, 2004) facilita a adesão de partículas de poluição, que são, predominantemente, apolares. Este fator é mais importante nos centros urbanos onde a maior parte da poluição atmosférica, segundo Pio (1998), é à base de carbono oriundo da queima de combustíveis fósseis

Dessa forma, é comum que se observem alterações de cor precoces nas vedações externas de edifícios cujos materiais de construção são protegidos com produtos hidrofugantes à base de silicone . A intensidade dessa adesão é, no mínimo, igual a dos materiais sem qualquer tipo de tratamento (Figura 2- 16).

Além disso, uma vez que a superfície é recoberta por partículas de poluição, tornase possível o crescimento de microrganismos, mesmo com uma menor quantidade de água disponível. Urzi, De Leo (2007), com base em investigações em laboratorial e de exposição controlada por quinze meses na cidade de Messina, Itália, confirmam que o uso de hidrofugante não consegue barrar o crescimento de fungos, como o 
cladosporium $s p$, que, também é o mais comum nas vedações externas brasileiras (shirakawa et al, 2004).

Outras consequencia do crescimento de fungos em superfícies tratadas com produtos à base de silicone é a perda de hidrorrepelência, porque os fungos conseguem quebrar as ligações da matriz siloxano com os radicais alquila.

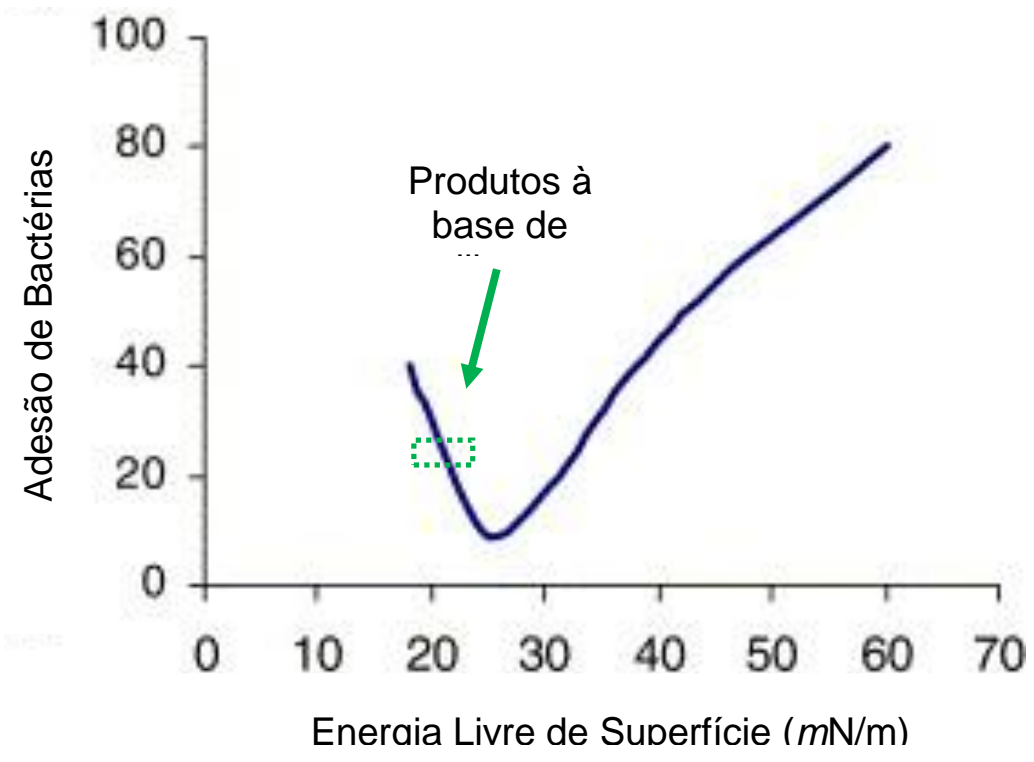

Figura 2- 15: Influência da tensão superficial na adesão de bactérias. Fonte: Baier apud Zhao et. al. (2005)

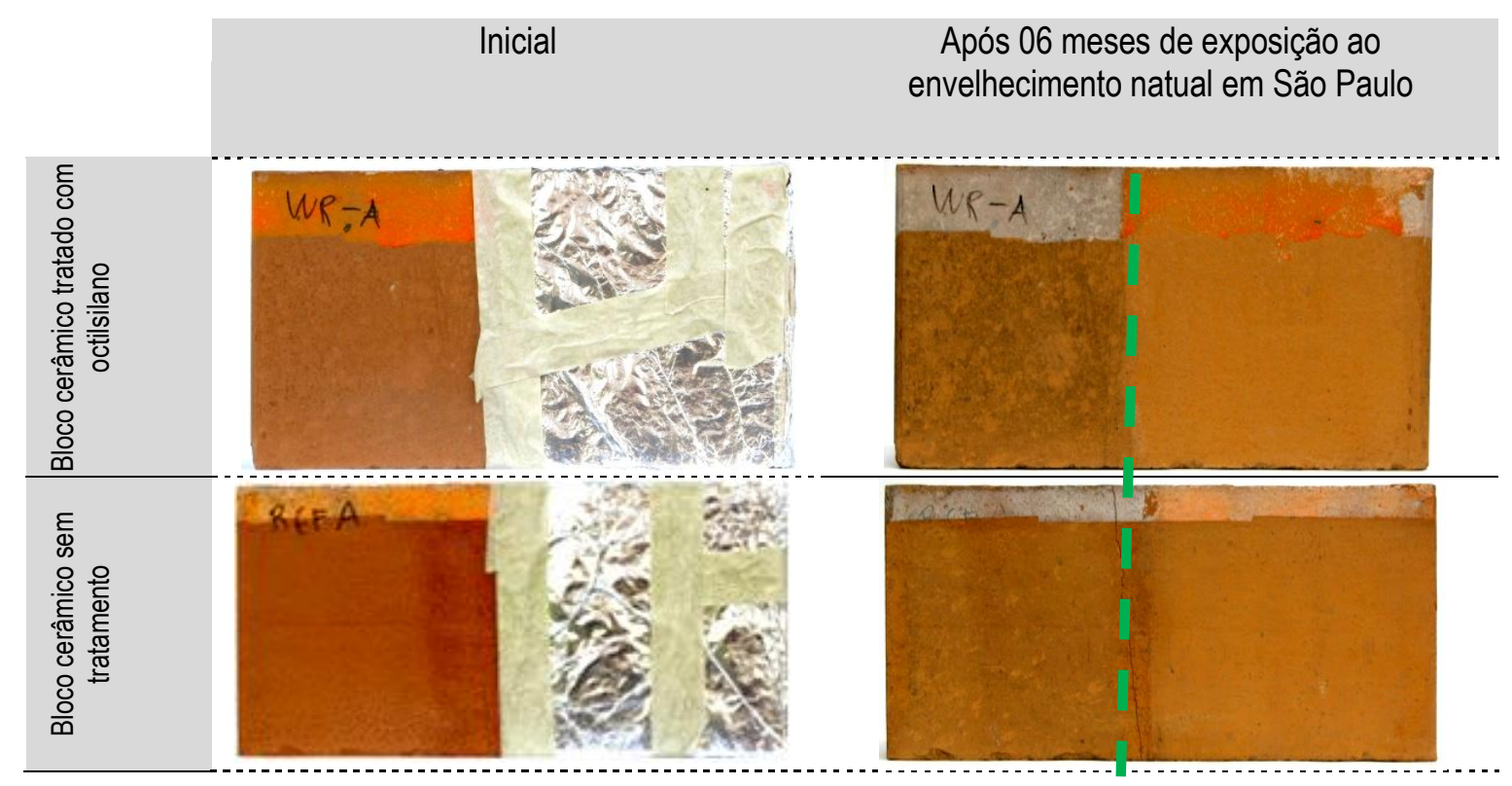

Figura 2- 16: llustração do surgimento de manchas causadas pela deposição de partículas de poluição em blocos cerâmicos expostos durante seis meses na cidade de São Paulo. Fonte: Arquivo pessoal. 


\subsection{Análise do Capitulo}

Diversos tipos de produtos hidrofugantes vêm sendo utilizados na construção civil com o objetivo de reduzir a tensão superficial dos materiais porosos e com isso sua aptidão à água.

Os mais utilizados, atualmente, são à base de silicones por apresentarem boa aderência aos substratos silicosos, boa repelência à água, elevada durabilidade, e não alterarem a aparência da superfície sobre a qual são aplicados. Dentre esses, destacam-se os silano-siloxanos, pois possuem moléculas pequenas o suficiente para penetrar em substratos pouco porosos, como granitos e concretos de elevadas resistências (características dos silanos), e apresentarem um menor consumo de material, característica dos siloxanos.

De modo geral, os silicones vêm se mostrando efetivo na redução da quantidade de água no interior dos materiais porosos, visto que diminuem a tensão capilar e os efeitos da condensação capilar. Como consequência, observa-se uma considerável redução no surgimento de manchas causadas pelo crescimento de microrganismos.

Por outro lado, suas características lipofílicas intensificam a deposição de partículas de poluição à base de carbono, fazendo com que escurecimentos precoces sejam observados nas superfícies externas dos edifícios. Isso possibilita as condições necessárias para o crescimento de fungos, que se desenvolvem em meios com baixa quantidade de água disponível.

Sua forma de aplicação mais usual é o pós-tratamento - pintura e spray para os materiais em serviço e imersão para as aplicações nas indústrias - e sua eficiência é significativamente influenciada pela profundidade de penetração no substrato.

Para que apresente o desempenho esperado é necessário que a especificação do material hidrofugante seja realizada de maneira adequada, compatibilizando suas propriedades com as do substrato, as condições de aplicação e os agentes de degradação que o solicitarão ao longo de sua vida útil. 


\section{CAPÍTULO III}

\section{Fotocatálise Aplicada aos \\ Materiais de Construção}

\section{Introdução}

A fotocatálise é um processo eletroquímico capaz de acelerar as reações de oxidação e redução de substâncias orgânicas pela simples incidência de luz ou energia radiante. Esta técnica vem sendo utilizada para a criação superfícies com propriedades auto-limpantes e despoluidoras, capazes de neutralizar partículas poluentes como $\mathrm{SO}_{x}, \mathrm{NO}_{x}$ e VOC (benzeno, tolueno e Xileno, por exemplo), em compostos inócuos como $\mathrm{CO}_{2}, \mathrm{H}_{2} \mathrm{O}$ e $\mathrm{O}_{2}$.

Sua descoberta ocorreu durante a década de 70 , quando os pesquisadores japoneses Honda e Fujishima, com o objetivo de criar sistemas para tratamento de água mais eficientes, constataram que alguns semicondutores podem produzir o ânion radical hidroxila quando incididos por radiação ultravioleta (Fujishima et. al., 2000).

A aplicação desse conceito em edificações teve início na década de 90 do século passado, novamente no Japão, quando empresas e universidades iniciaram os testes em concretos e placas cerâmicas. Desde então, o interesse pela fotocatálise, aplicada a outros materiais de construção, vem crescendo.

O grande impulso para sua disseminação foi, sem dúvida, a criação do projeto PICADA pela União Europeia (www.PICADA-PROJECT.com), cujo o objetivo foi investigar o potencial de utilização de materiais de construção com propriedades fotocatalíticas para a despoluição de centros urbanos.

Esse projeto contou com participantes de toda a cadeia produtiva e durou cerca de quatro anos, de 2001 a 2005. Como principais resultados foram publicados mais de uma dezena de artigos em congressos e revistas científicas internacionais, além do desenvolvimento de produtos, tais como: cimento com propriedades fotocatalíticas (TxActive $®)$, tintas acrílicas (TPX-85® e TPX-220®), entre outros.

Atualmente, vários produtos já são comercializados com os princípios da fotocatálise, onde destacam-se:

- os vidros e os espelhos anti-embaçantes;

- as tintas, o cimento e os vidros auto-limpantes;

- as placas cerâmicas esmaltadas, purificadores de ar e água com propriedades anti-bactericidas. 
Dentre esses produtos, o que possui maior sucesso comercial é o vidro autolimpante (Mills et. al., 2006) que já vem sendo comercializado por várias empresas, podendo-se citar (incluindo o nome comercial entre parênteses): Pilkington Glass (Active $^{\mathrm{TM}}$ ); Pittsburg Plate Glass (SunClean $\left.{ }^{\circledR}\right)$; St-Gobain (Bioclean ${ }^{\circledR}$ ) e AFG (Radiance Ti®).

No Brasil, não foi identificada nenhuma pesquisa que focasse o uso da fotocatálise nos materiais de construção. Identificaram-se, apenas, os trabalhos liderados pelo Professor Dr. Wilson Jardim, do Departamento de Química da Unicamp, e da Professora Dra. Marcia Makito Kondo da Universidade Federal de Itajubá, que concentram esforços no tratamento de água e de efluentes industriais.

\subsection{Principio Físico}

A fotocatálise baseia-se no deslocamento de elétrons da camada de valência para a camada condutora que alguns materiais apresentam quando incididos por radiação ultravioleta. Como consequência, ocorrem dois fenômenos simultâneos: reação de oxi-redução de substâncias adsorvidas na superfície e aumento da hidrofilicidade (redução do ângulo de contato).

Isso acontece nos semicondutores por possuírem uma camada de valência incompleta e uma camada condutora separadas por uma "band-gap" (hv) compatível com a energia fornecida pela radiação solar na faixa do UV (Figura 3-1). Nos condutores, essa "bandgap" é inexistente, enquanto que nos isolantes ela é grande o suficiente para impedir a troca de elétrons (Figura 3-2).

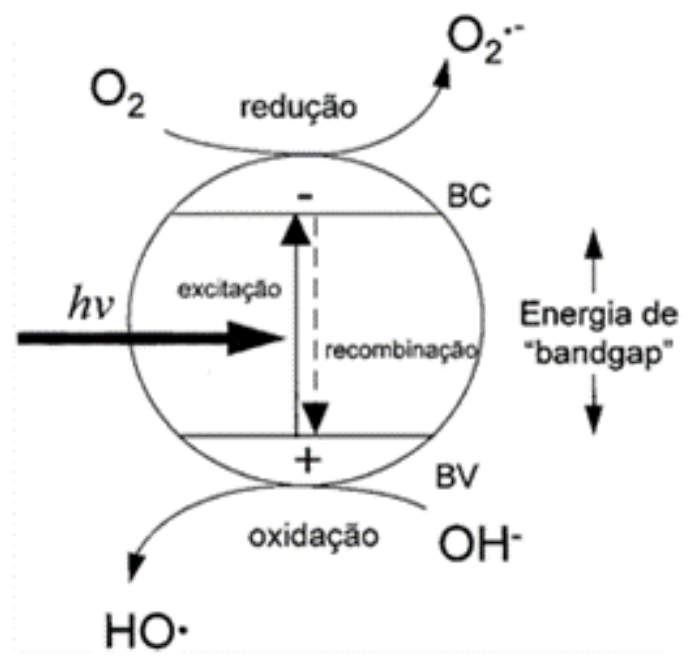

Figura 3- 1: Esquema de oxidação de redução de semicondutores. BV = Banda de Valência e BC = Banda Condutora.

Nos semicondutores, essas lacunas apresentam potenciais bastante positivos, na faixa de $+2,0$ a $+3,5 \mathrm{eV}$, que é suficiente para gerar radicais $\mathrm{HO}^{\circ}$ a partir de moléculas de água adsorvidas. Esses radicais, por sua vez, possuem o poder de oxidação suficiente para degradar compostos orgânicos (Nogueira; Jardim, 1998 e Souza, 2003). 


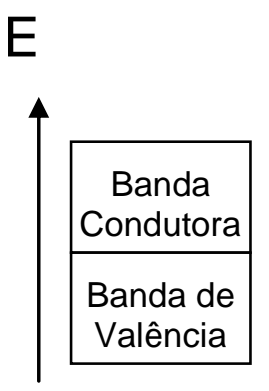

condutor

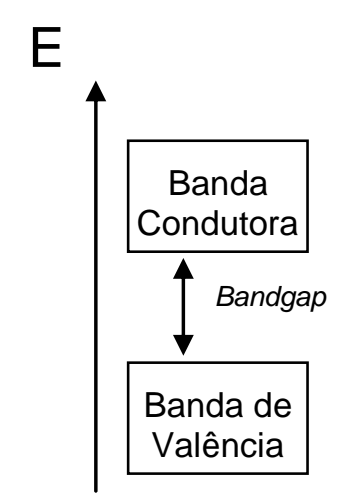

Semi-condutor

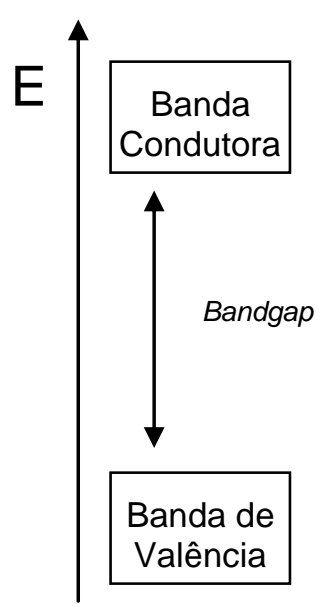

isolante

Figura 3- 2: Ilustração das diferenças entre os orbitais de compostos condutores, semicondutores e isolantes. Baseado em Ambrosio Junior (sd.)

A sequência de reações que ocorrem pode ser assim resumida:

1) A incidência do UV na faixa adequada dá início ao processo fotocatalítico pelo deslocamento de elétrons da banda de valência para a condutora, gerando, assim, o par elétron/buraco (do inglês electron/hole) ;

$$
\mathrm{TiO}_{2} \stackrel{h v}{\rightarrow} \mathrm{TiO}_{2}\left(e_{B C}^{-}+h_{B V}^{+}\right) \quad \text { equação } 4.1
$$

2) A falta de elétrons na camada de valência em contato com a água adsorvida na superfície consegue dissociar a água em $\mathrm{OH}^{-}$e $\mathrm{H}^{+}$;

$$
h_{B V}^{+}+\mathrm{H}_{2} \mathrm{O}_{\mathrm{ADS}} \rightarrow \mathrm{OH}^{-}+\mathrm{H}^{+} \quad \text { equação } 4.2
$$

3) A falta de elétrons na camada de valência $\left(h_{B V}^{+}\right)$age na $O H^{-}$, dissociada da água, para formar o radical hidroxila;

$$
h_{B V}^{+}+\mathrm{OH}^{-} \rightarrow \mathrm{HO}^{\circ} \quad \text { equação } 4.3
$$

4) Simultaneamente, o elétron que foi deslocado para a banda condutora reduz o oxigênio formando o ânion superóxido;

$$
e_{B C}^{-}+O_{2} \rightarrow O_{2}^{-}
$$

equação 4.4

5) Por último, o ânion superóxido reage com o $\mathrm{H}^{+}$dissociado da água para produzir radicais hidroperóxidos $\left(\mathrm{HO}_{2}^{\circ}\right)$;

$$
\mathrm{O}_{2}^{-}+\mathrm{H}^{+} \rightarrow \mathrm{HO}_{2}^{\circ}
$$

equação 4.5

Diversos semicondutores vêm sendo testados para aplicações fotocatalíticas. Para os materiais de construção, especificamente, constata-se uma larga predominância dos óxidos de titânio, em especial o anatásio, porque apresenta elevado poder fotocatalítico, grandes reservas existentes no mundo, baixo custo de obtenção e 
processamento e baixa toxidade quando comparados com outros semicondutores (Chen; Poon, 2009).

Por esse motivo, esta tese só abordará o semicondutor de Dióxido de Titânio $\left(\mathrm{TiO}_{2}\right)$ como agente promotor de fotocatálise.

\subsubsection{Fatores que Influenciam no Desempenho da Fotocatâlise}

Os principais fatores que influenciam no desempenho dos processos fotocatalíticos são a quantidade de partículas fotoativadas, a dimensão dessas partículas e a estrutura cristalina do semicondutor (Jang et. al.,2001 e Wade, 2005):

a) Quantidade de partículas fotoativadas: quanto mais partículas de dióxido de titânio em contato com a radiação ultra-violeta, maior o desempenho fotocatalítico. Ocorre, porém que quando adicionado à mistura a parcela ativa é, apenas, a que fica em contato com a radiação UV na superfície do substrato.

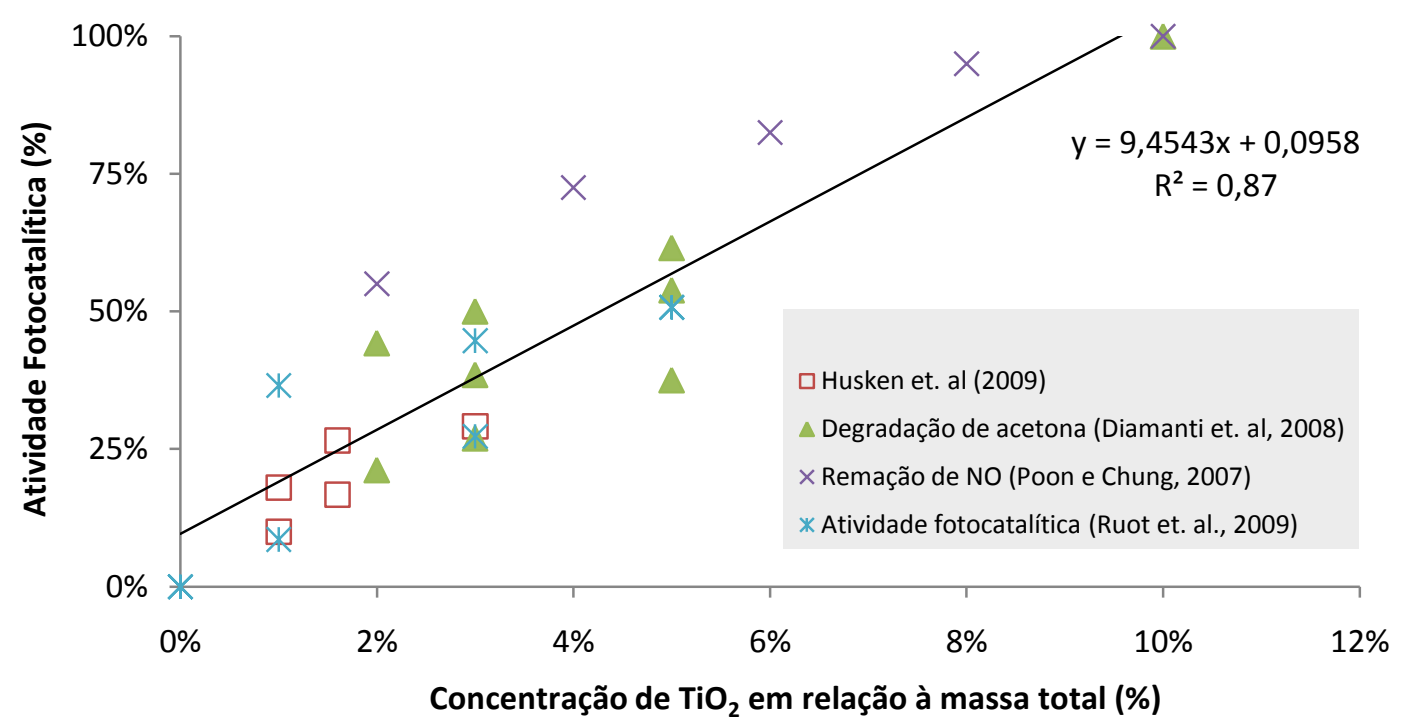

Figura 3- 3: Influência da concentração de partículas fotoativadas na atividade fotocatalítica

b) Tamanho de partícula: as partículas devem ser nanométricas, sendo tanto mais efetivo quanto menor for sua dimensão (Figura 3- 4). Trabalhos mais recentes, porém, propõem que as partículas com dimensões de 15nm apresentam as mais intensas atividades fotocatalíticas, pois aperfeiçoa a dinâmica de transferência de elétrons e da absorção da radiação incidente (Figura 3- 5). 


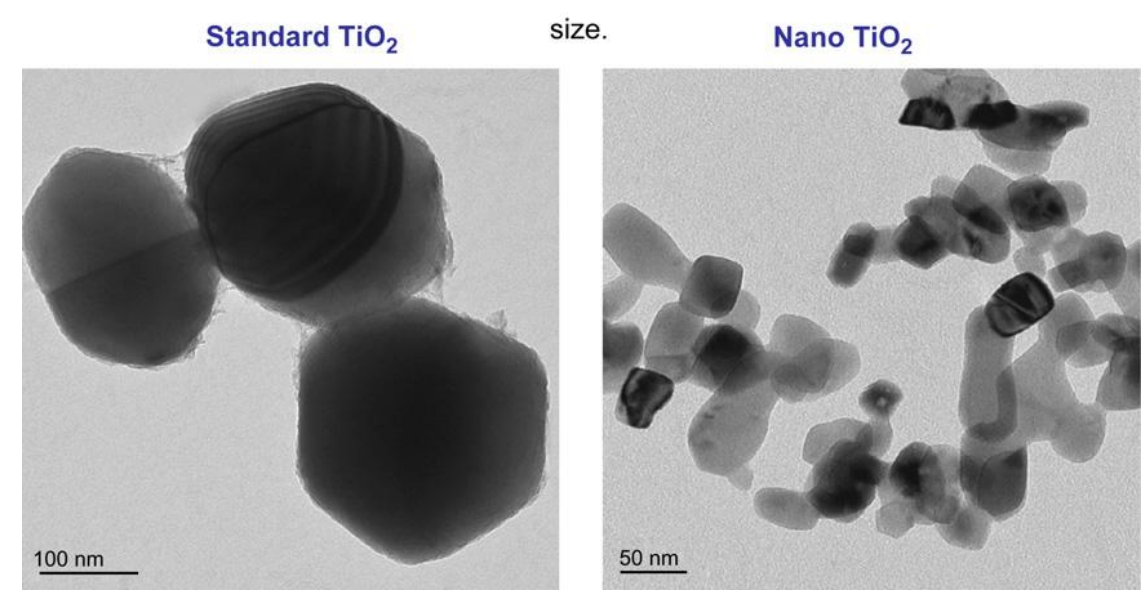

Figura 3- 4: Diferença de dimensão entre as partículas utilizadas para pigmentos em tintas (standard $\mathrm{TiO}_{2}$ ) e em processos fotocatalíticos (nano $\mathrm{TiO}_{2}$ ). Fonte: Allen et. al. (2008).

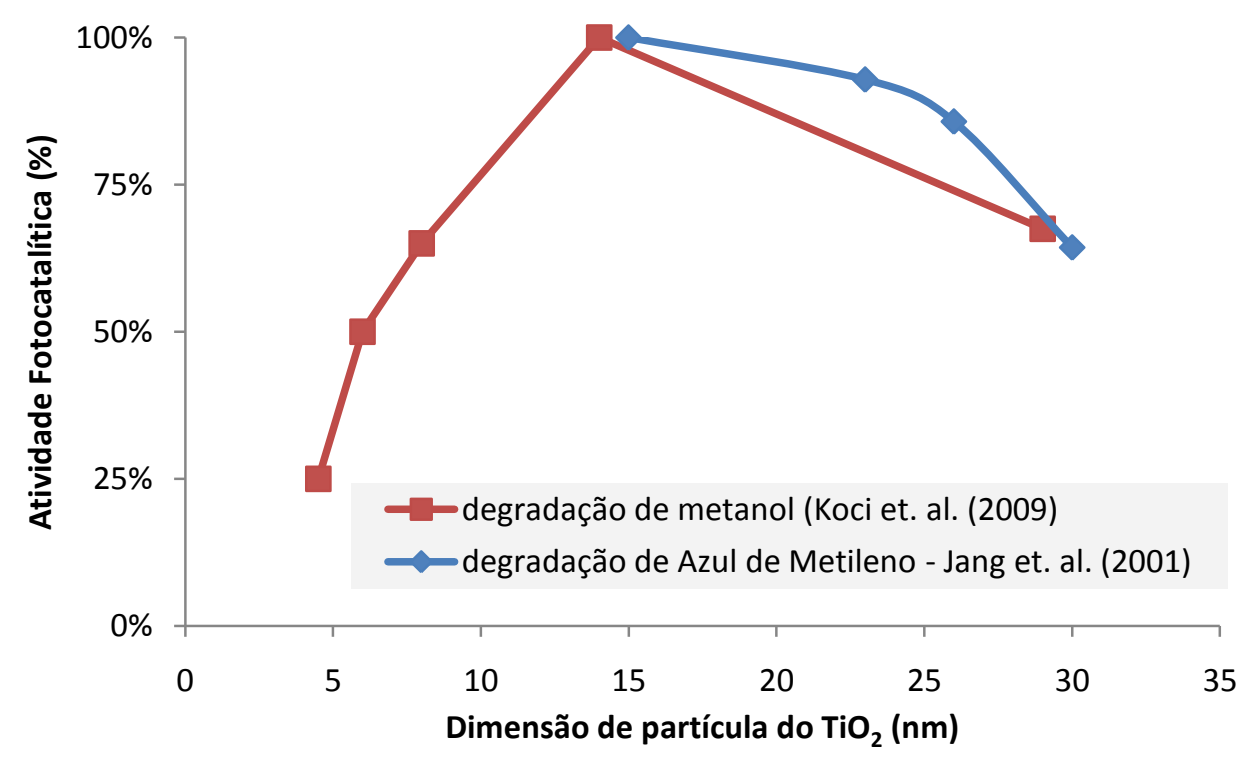

Figura 3- 5: Influência do tamanho de partículas de $\mathrm{TiO}_{2}$ na atividade fotocatalítica. Baseado em Jang et. al., 2001 e Koci et. al. (2009).

c) Estrutura cristalina: o dióxido de titânio possui duas formas cristalográficas predominantes ${ }^{9}$ : rutilo e anatásio (Tabela 2). Para a obtenção de ambas, o processo cloro é o mais utilizado, e os produtos comerciais são formados pela mistura dos dois (Oliveira, 1997). O rutilo é bastante utilizado como opacificante e como pigmento na área de tintas e plásticos, enquanto que anatásio é a que vem sendo mais investigada para a fotocatálise, principalmente porque possui maior bandgap. Por isso, quanto maior o teor de anatásio no semicondutor, mais efetiva é a atividade fotocatalítica (Figura 3-6).

\footnotetext{
${ }^{9}$ A bruquita é uma terceira forma cristalográfica possível do dióxido de titânio; porém, não possui interesse comercial por não ser estável.
} 
Tabela 2: Propriedades das diferentes fases cristalográficas dos dióxidos de titânio (www.mindat.org).

\begin{tabular}{l|l|l} 
Propriedades & Rutilo & Anatásio \\
\hline Forma cristalográfica & Sistema tetragonal & Sistema tetragonal \\
\hline Densidade $\left(\mathrm{g} / \mathrm{cm}^{3}\right)$ & 4,27 & 3,90 \\
\hline Índice de refração & 2,72 & 2,52 \\
\hline Dureza (Mohs) & $6,0-6,5$ & $\begin{array}{l}\text { T,5-6,0 } \\
\text { Transforma-se em rutilo } \\
\text { acima de } 800 \circ \mathrm{C}\end{array}$
\end{tabular}

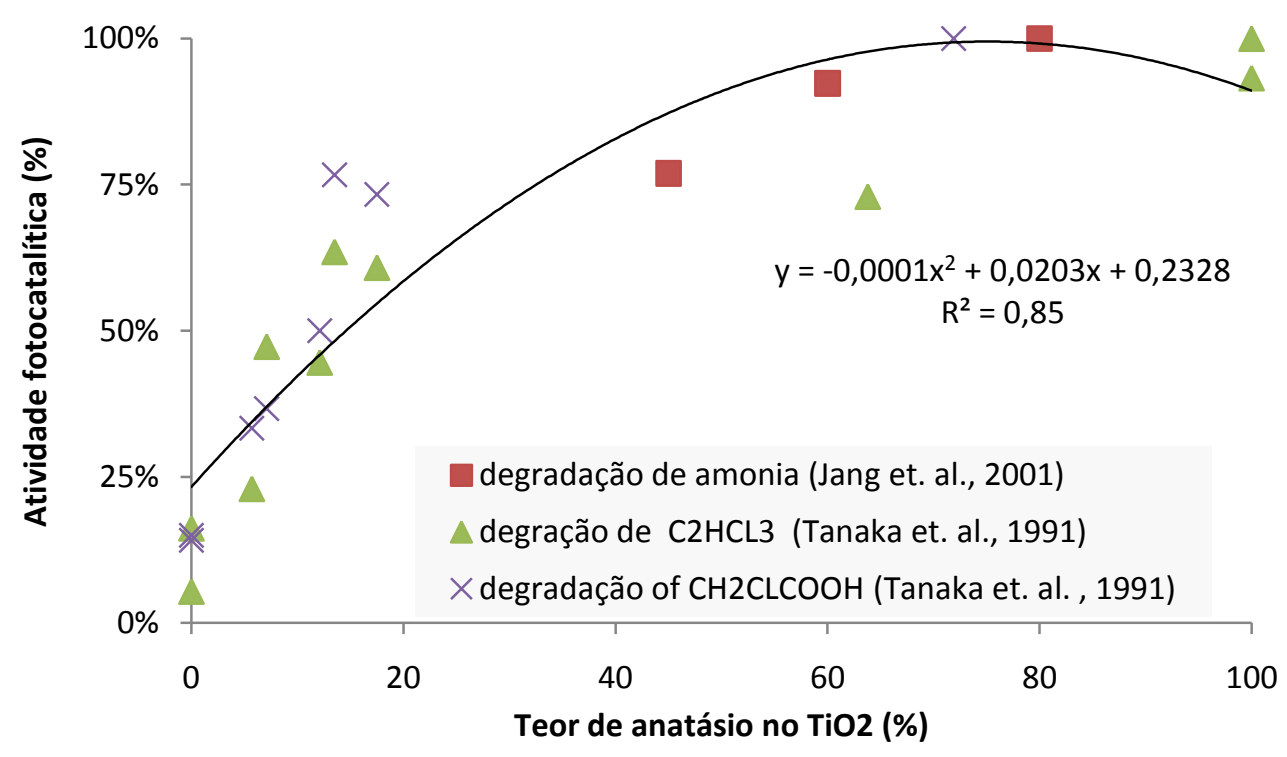

Figura 3- 6: Efeito do teor de anatásio na atividade fotocatalítica.

\subsection{Mecanismo de Funcionamento}

A ação antissujidade e despoluidora de superfícies com propriedades fotocatalíticas atuam de maneira conjunta.

Quando a superfície recebe radiação ultravioleta durante o dia, ocorrem os processos de oxidação e degradação de compostos orgânicos que foram depositados na superfície durante o período noturno. Simultaneamente, ocorre a redução do ângulo de contato e o arraste das partículas aderidas quando há chuva (Figura 3- 7). 

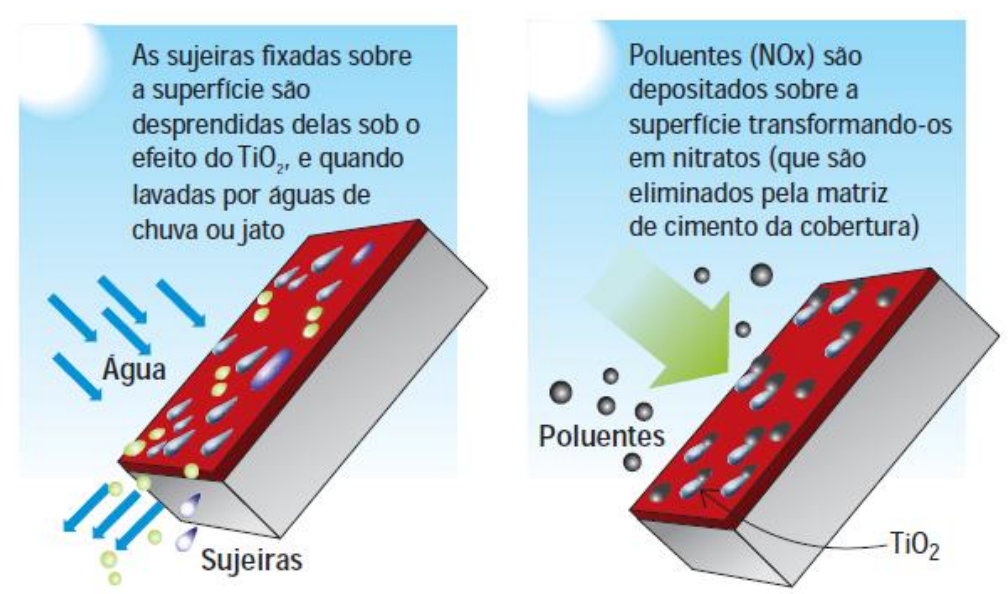

Figura 3- 7: Mecanismo de ação de superfície fotocatalítica. Baseado em www.PICADA-PROJECT.com

A oxidação de compostos orgânicos vem sendo alvo de estudos em todo o mundo, visto que, quando ocorrem de maneira completa, os únicos subprodutos dos processos fotocatalíticos são o gás carbônico, a água e ácidos fracos. Quando incompletos, porém, são gerados ozônio e $\mathrm{NO}_{2}$ (Gurol, 2006 e Maggos et. al., 2008).

Algumas dessas reações estão apresentadas abaixo:

a) $\mathrm{NO}_{x}$ (Chen; Poon, 2009):

$$
\begin{gathered}
\mathrm{NO}+\mathrm{HO}_{2}^{\circ} \quad \frac{\text { fotocatalise }}{\mathrm{TiO}_{2}} \rightarrow \mathrm{NO}_{2}+\mathrm{HO}^{\circ} \\
\mathrm{NO}_{2}+\mathrm{HO}^{\circ} \frac{\text { fotocatalise }}{\mathrm{TiO}_{2}} \rightarrow \mathrm{HNO}_{3}
\end{gathered}
$$

b) O poluente orgânico carbono elementar (Mills et. al., 2006-b):

$$
\mathrm{C}+\mathrm{O} \frac{\text { fotocatalise }}{\mathrm{TiO}_{2}} \rightarrow \mathrm{CO}_{2}
$$

c) Ácido esteárico (Mills et. al., 2006-a):

$$
\mathrm{CH}_{3}\left(\mathrm{CH}_{2}\right)_{16} \mathrm{CO}_{2} \mathrm{H}+26 \mathrm{O}_{2} \frac{\text { fotocatalise }}{\mathrm{TiO}_{2}} \rightarrow 18 \mathrm{CO}_{2}+18 \mathrm{H}_{2} \mathrm{O}
$$

Tão importante quanto o processo e decomposição é o arraste dos subprodutos que se depositam na superfície da superfície dos materiais e impedem novos ciclos de foto-ativação, pois agem como barreira ao UV (Yu, 2003). Isso é possível porque os processos fotocatalíticos transformam a superfície em super-hidrofílica, onde a lâmina de água é formada, como consequência dos ângulos de contato próximos de zero que proporcionam. Este fenômeno, porém, é reversível e quando retirada a radiação UV, percebe-se um contínuo aumento do ângulo de contato Figura 3- 8. 
Por isso, materiais com propriedades fotocatalíticas devem ser usados em locais com elevada inclinação, como fachadas e telhados de edifícios.

A cinética deste fenômeno mostra que a perda das propriedades fotocatalíticas ocorre de maneira muito rápida. Ou seja, se para reduzir o ângulo de contato a valores próximos de zero forem necessários horas de exposição à radiação UV, o aumento se dará em dezenas minutos.

Para evitar essa rápida recuperação do ângulo de contato, e maximizar o efeito fotocatalítico, alguns autores têm proposto a utilização de substâncias dopantes, como silício e prata (Guan, 2005). Isso faz com que o tempo para recomposição seja aumentado em várias vezes (Figura 3- 8) sendo necessários dias para o retorno aos valores iniciais.

Por extrapolar o objetivo de pesquisa desta tese, a questão de dopagem do anatásio não será aprofundada.

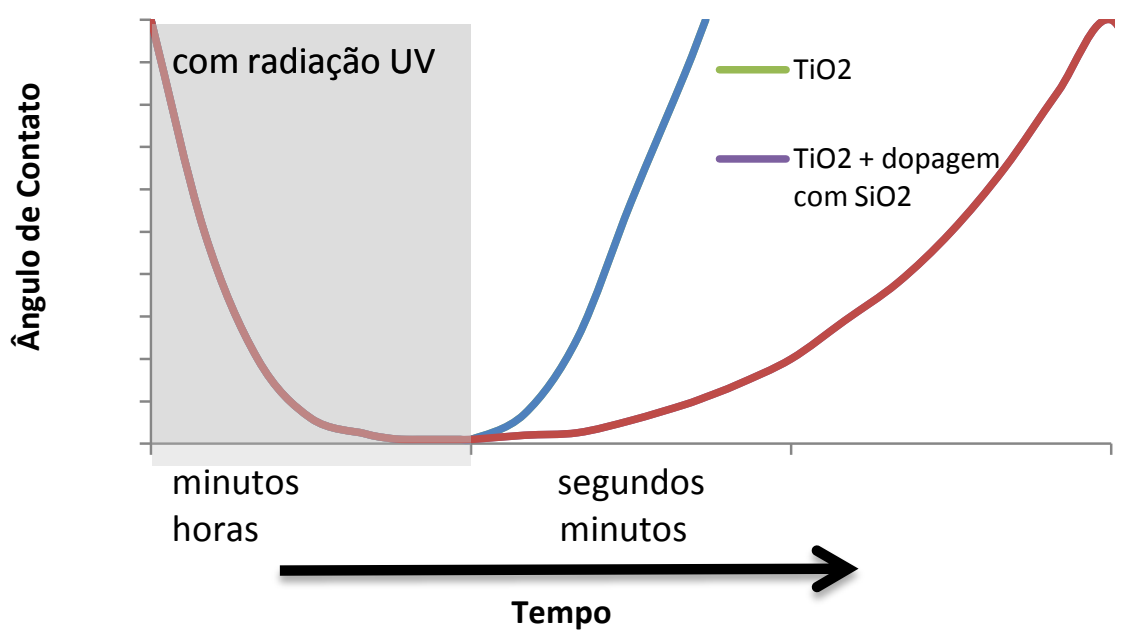

Figura 3- 8: Cinética do ângulo de ângulo de contato em função da presença ou não da radiação UV. Baseada nos resultados de Guan et. al. (2003), Guan (2005), Irie; Hashumoto (2005), Cai et. al. (2006) e Määttä et. al. (2007).

\subsection{Aplicaçő̃es da Fotocatálise}

O interesse pela fotocatálise vem crescendo de forma muito significativa nos últimos anos. Já existem mais de 5000 publicações cadastradas no sítio www.isiknowledge.com e mais de 750 patentes depositadas no sítio http://www.freepatentsonline.com, quando se usa a palavra "photocatalysis" no sistema de busca, sendo que os principais campos de aplicação são os sistemas de tratamento de água e de purificação de ar.

Especificamente para os materiais de construção civil, foram identificadas, no dia 27 de agosto de 2009, apenas 31 publicações quando foram usadas as palavras chaves "photocatalysis building" nas mesmas bases de dados supracitadas e restringidos os resultados pra as áreas de engenharias e ciências dos materiais. 
Essa baixa concentração de trabalhos para a construção civil já foi anteriormente destacada por Mills; Lee (2002).

Além disso, a maior parte dos trabalhos foca os materiais não-porosos, principalmente $o$ vidro, restando poucas publicações sobre os materiais porosos e silicosos, objetivo desta tese.

Do ponto de vista de aplicação em edificações, destaca-se que desde 1999 já há exemplos de aplicações em escala piloto. Cassar (2004), fazendo uma análise histórica, destaca: uma escola em Mortara (Itália) no ano de 1999; a cidade da música (cite de la musique) em Chambéry, França, no ano de 2000; a Catedral da Misericórdia (dives in Misericordia) em Roma, Itália, no ano de 2003 (Figura 3- 9); e a Central da Policia, em Bordeaux, França, no ano de 2003.
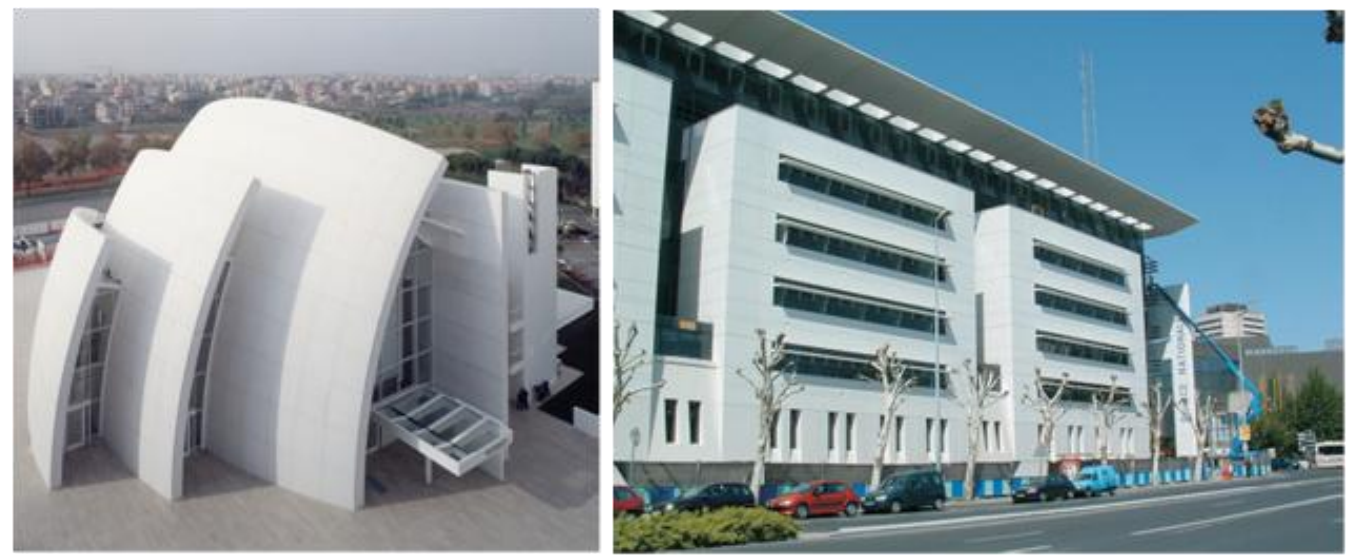

Figura 3- 9: Exemplos de uso de concretos com propriedades fotocatalíticas. Catedral da Misericórdia (Roma, Itália) e na Central da Polícia (Bordeaux, França). Obtido em http://www.italcementigroup.com no dia 22 de janeiro de 2008.

Além dos exemplos supracitados, merecem ser destacado os pavimentos cimentícios (pavers) na cidade de Honk Kong (Yu, 2003); pavers na cidade de Antuerpia (Beeldens, sd.); e as placas de fibrocimento sem amianto apresentadas por Yuranova et. al. (2007).

Por ser uma técnica que, potencialmente, consegue reduzir a quantidade reduzir o degradar a poluiçà atmosférica, estudo para a sua aplicação como instrumento de saúde pública, vem sendo feito em muitas partes do mundo, podendo-se citar:

Em virtude disso, a técnica vem sendo estudada e aplicada em escala piloto em diversas partes do mundo, podendo-se citar:

- California: http://www.csus.edu/calst/government affairs/reports/PHOTO-CATALYTIC.pdf

- Houston: http://files.harc.edu/Projects/JointCenter/Projects/PhotocatalyticCoatingPavement.pdf

- Japão: http://www8.cao.go.jp/cstp/nanoweb/e pdf/P18-19 e.pdf

- Roma: http://www.chusid.com/pdf/essroc.pdf

- Londres: http://old.certh.gr/downloads/en/InnovationConference/wshop2/2.3$\% 20$ N.\%20Moussiopoulos\%20.pdf

- Honk Kong: http://www.epd.gov.hk/epd/english/environmentinhk/air/studyrpts/files/reportupdatedcb paving blocks 2003.pdf 


\subsection{Produção de Superficies com Propriedades Fotocataliticas}

Diversos métodos vêm sendo utilizados para a criação de superfícies com propriedades fotocatalíticas.

Quando aplicados em materiais não-porosos, como vidros e metais, os métodos mais comumente utilizados baseiam-se na dispersão do dióxido de titânio em água isoladamente, ou em conjunto com algum álcool, seguido da deposição pelos processos de sol-gel, dip coating ou spin coating, e cura com elevadas temperaturas (Muggli; Ding, 2001; Zan et. al., 2004; Bellardita et. al., 2007, Herrmann et. al., 2007; Habibi; Nasr-Esfahani, 2007). Um exemplo disso, são os produtos PTA-85 e PTA170 da greenmillenium onde se especifica que devam ser curados a temperaturas entre $250^{\circ} \mathrm{C}$ e $600^{\circ} \mathrm{C}$ para que apresentem propriedades fotocatalíticas (http://www.greenmillennium.com/gmiproducts.htm).

Quando aplicados sobre materiais orgânicos (tintas e PVC, por exemplo), a utilização de cura com temperatura elevada fica impossibilitada e se torna necessária a proteção do filme polimérico, para evitar a formação de fissuras (Figura 3- 10) e o chalking (Allen et. al., 2008). Para tanto, faz-se necessário que a aplicação seja feita em mais de uma etapa, onde primeiro é depositada a camada de inertes e, sobre esta, as partículas fotocatalíticas. Isso, vem sendo feito pela técnica de sol-gel, em que a sílica coloidal forma a camada de inertes, e os radicais silanol ( $\mathrm{SiOH}$ ), gerados a partir dessa sílica, são usados como agentes de ligação do substrato e das partículas de dióxido de titânio hidrolisadas superficialmente (Guan, 2005, Cai et. al., 2006 e Yuranova et. al., 2007).
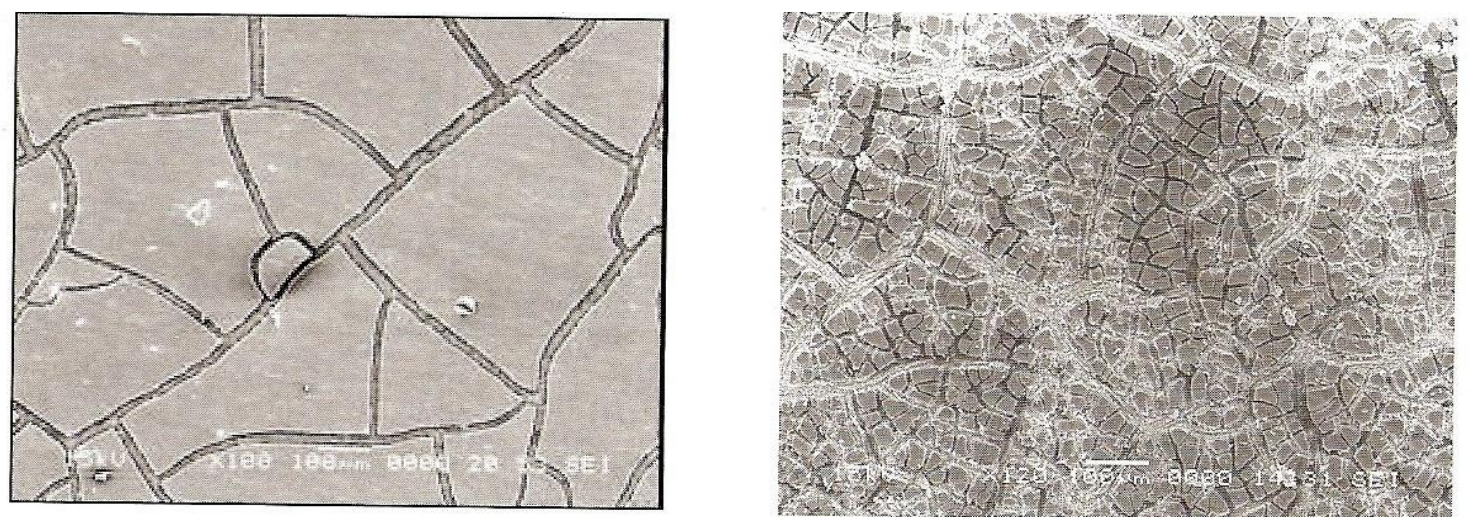

Figura 3- 10: Fissuras causadas pela atividade fotocatalítica do TiO2 em filmes de poliuretano. (Motohashi; Inukai, 2007). Direta $=$ inicial e esquerda $=$ após 5,5 anos de exposição natural.

Para os materiais silicosos e porosos, objetos desta tese, os métodos mais comumente encontrados são o sol-gel (Potenza et. al., 2007), a pintura com tinta mineral (Valléé, et. al., 2004 e Beeldens, sd.; Diamanti et. al., 2008), a pulverização do semi-condutor após conformação do componente e antes do endurecimento 
(Chen; li, 2007) e pós-tratamento com agentes ligantes orgânicos (Santos, 2004; Santos; Kondo, 2006 e Diamanti et. al., 2008).

Para a área de concretos e argamassas, constata-se que parte das pesquisas adiciona o semi-condutor durante a mistura (Cassar et. al., 2003; Santos \& Kondo, 2006). Nesses casos, o teor de dióxido de titânio utilizado é bastante variado, havendo casos em que foi usada uma concentração de $1 \%$ da massa total e outros com 15\% (Furumura et. al, 2006 e Diamanti et. al., 2008).

Uma grande desvantagem de se adicionar o semicondutor à mistura é que o custo do produto final é bastante elevado, pois o dióxido de titânio nanométrico é muito mais caro do que outros materiais de construção, tais como cimento e agregado. Um exemplo disso é o cimento com propriedades fotocatalíticas que, nos EUA, custam seis vezes mais do que o portlando comum (Katzman, 2006).

Por isso, mesmo nos concretos e pavers, a forma de aplicação mais comum é em dois estágio, onde sobre um substrato não tratado, deposita-se uma camada, com $1,0 \mathrm{~cm}$ de espessura, com propriedades fotocatalíticas, usando o próprio cimento como ligante (Figura 3- 11). Autores como Cassar et. al. (2003), Yu (2003) e Poon; Cheung (2007) apresentam exemplos de sucesso com esse tipo de aplicação sobre concretos e paver, onde o teor de dióxido de titânio, em relação à massa total, variou de $3 \%$ a $10 \%$.

Apesar de ser otimizada, quando comparada à adição em toda a espessura do componente, na aplicação em dois estágio também há um importante parcela do semicondutor também não receberá a incidência de radiação UV e não contribuirá com o efeito fotocatalítico. Por isso, Chen; Poon (2009) propõem que devam ser adicionadas partículas de vidro, UV no corpo do componente, que possibilitam a penetração de radiação e que uma maior parcela do dióxido de titânio seja fotoativado (Figura 3-12).

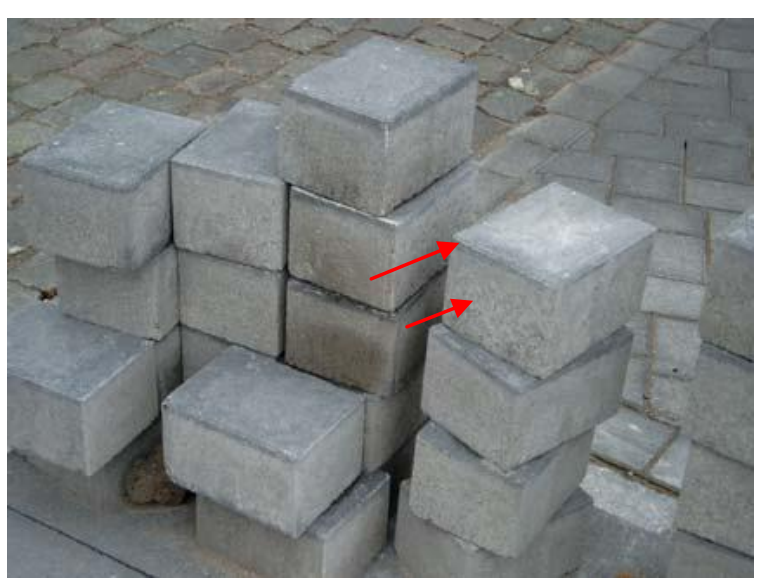

Figura 3- 11: Exemplo da aplicação da camada fotocatalítica em duas camadas sobre paver. Fonte: (beldens, sd)

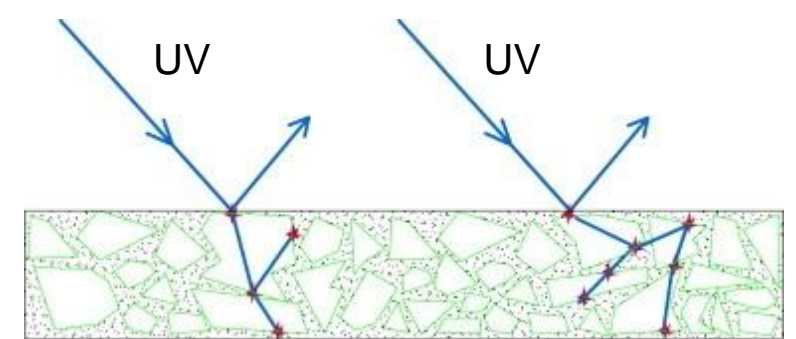

partículas de vidros cimento modificado com $\mathrm{TiO}_{2}$ partículas de $\mathrm{TiO}_{2}$ foto ativadas

Figura 3- 12: Ação das partículas de vidro na fotoativação do semicondutor.Fonte: Chen; Poon (2009)

Mesmo com essas melhoras incrementais, o uso de uma camada espessa não se configura na maneira mais otimizada para a produção de superfície com propriedades fotocatalíticas. Isto porque gera um grande despedício de 
semicondutor que não contribui para a atividadade fotocatalítica, pois não recebe radiação UV; porque altera as propriedades estéticas do substrato (Figura 3-13) e porque fornece uma menor quantidade de partículas, expostas à radiação UV.

Como consequencia, há uma redução da atividade fotocatalítica quando comparada as aplicações com suspensões aquosas sobre substratos inorgânicos (Diamanti et. a., 2007 e Diamanti et. a., 2008).

Apesar disso, um método de pós-tratamento que otimize a exposição de partículas do semicondutor à radiação UV ainda é necessário, uma vez que as suspensões aquosas apresentam baixa aderência e grande desprendimento do semicondutor após pouco tempo de exposição (Diamanti et. a., 2008); e porque as pinturas minerais, com o cimento como ligante só são adequadas quando se deseja coloração branca (Figura 3-14).

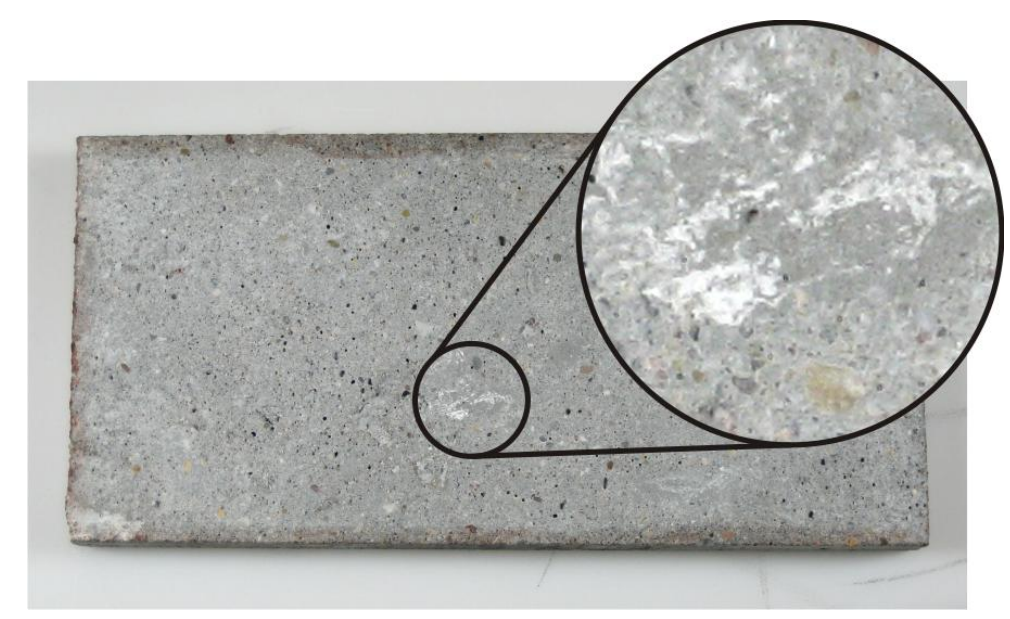

Figura 3- 13: Manchas esbranquiçadas em um paver produzido em dois estágios, cuja superfície mais externa apresenta propriedade fotocatalíticas . Fonte: Husken; Brouwers (2008)
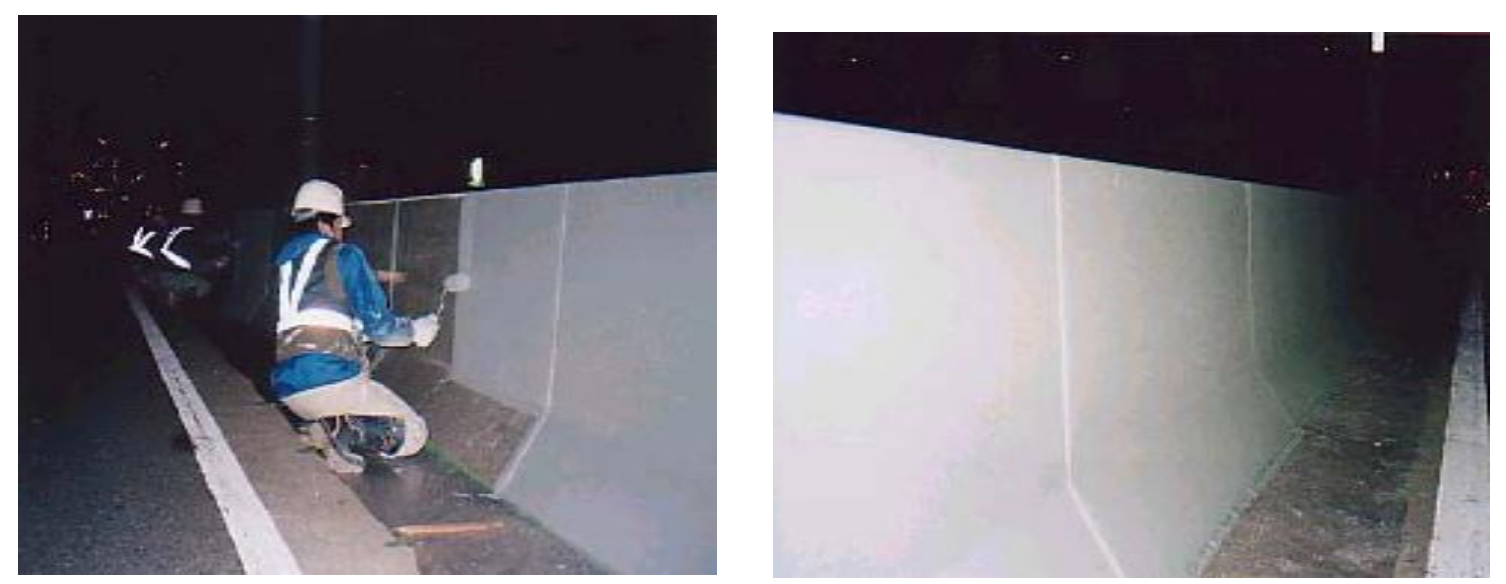

Figura 3- 14: Aplicação do pós-tratamento de concreto com película de $\mathrm{TiO}_{2}$ (Hanehara, 2005). 
Nesse sentido, os hidrofugantes à base de silicone podem ser usados como agente de ligação do semicondutor aos substratos silicosos e porosos, possibilitando o desenvolvimento de um método efetivo para aplicações como pós-tratamentos. Isso porque libera radical silanol durante a sua policondensação e consegue se ligar bem aos substratos silicosos e porosos. Essa é a hipótese fundamental dessa tese e investigada no programa laboratorial apresentado nos capítulos 4 e 5.

Destaca-se, ainda, que não foi encontrado, na literatura pesquisada, qualquer trabalho que tenha utilizado o anatásio em conjunto com produtos hidrofugantes à base de silicone para o tratamento de materiais porosos, objeto desta tese. O único trabalho que uniu o silicone e a fotocatálise utilizou substratos de alumínio (Motohashi; Inukai, 2007).

\subsection{Durabillidade}

Poucos trabalhos publicados apresentam dados quantitativos sobre a durabilidade dos processos fotocatalíticos, sendo este um dos principais gargalos para o maior desenvolvimento dessas técnicas (Gurol, 2006).

Por ser um processo natural, que depende apenas da movimentação de elétrons em escala atômica e posterior liberação da energia da bandgap, é de se esperar que não haja alteração de seu desempenho ao longo do tempo. Autores como Cassar (2004) e Vallée et. al. (2004), com base em estudos em ambiente laboratorial e em escala piloto de produtos cimentícios, confirmam que não há redução da atividade fotocatalítica com o passar do tempo.

Ocorre, porém, que alguns outros trabalhos vêm apresentando resultados contrários.

Para o caso de sistemas de tratamento de água, Rao et. al. (2004) descreve que após quatro semanas de exposição à ambiente agressivo, a lixiviação de partículas de anatásio e a formação de filme de subprodutos dos processos fotocatalíticos são responsáveis pela redução de mais de $50 \%$ de sua eficiência inicial.

Para o caso de pavers, Yu (2003) demostra que após quatro meses de exposição ao tráfego de pedestres nas calçadas de Honk Kong, o poder fotocatalítico foi reduzido de maneira muito significativa, como consequencia da perda de área exposta à radiação UV causada pela adesão de chicletes e óleo. Corpos-de-prova pares, que não foram expostos ao tráfego, não apresentaram qualquer tipo de modificação.

Lackhoff et. al. (2003), baseado em experimentos em escala laboratorial, acrescentam ainda que o processo de carbonatação dos produtos cimentícios hidratados reduz o poder fotocatalítico de concretos (Figura 3- 15). Poon; Cheng (2007) também chegaram a conclusões semelhantes para o caso de pavers.

Apesar de não haver maiores explicações para este fenômeno, acredita-se que ele seja causado pela deposição de portlandita (hidróxido de cálcio) e posterior carbonatação sobre o semicondutor. Isso faz com que a quantidade de partículas fotoativadas seja continuamente reduzida. 
Todos esses trabalhos confirmam que a união entre o cimento portland $\mathrm{e}$ as partículas do semicondutor provoca uma importante perda de atividade fotocatalítica. Portanto, outros ligante devem ser usados.

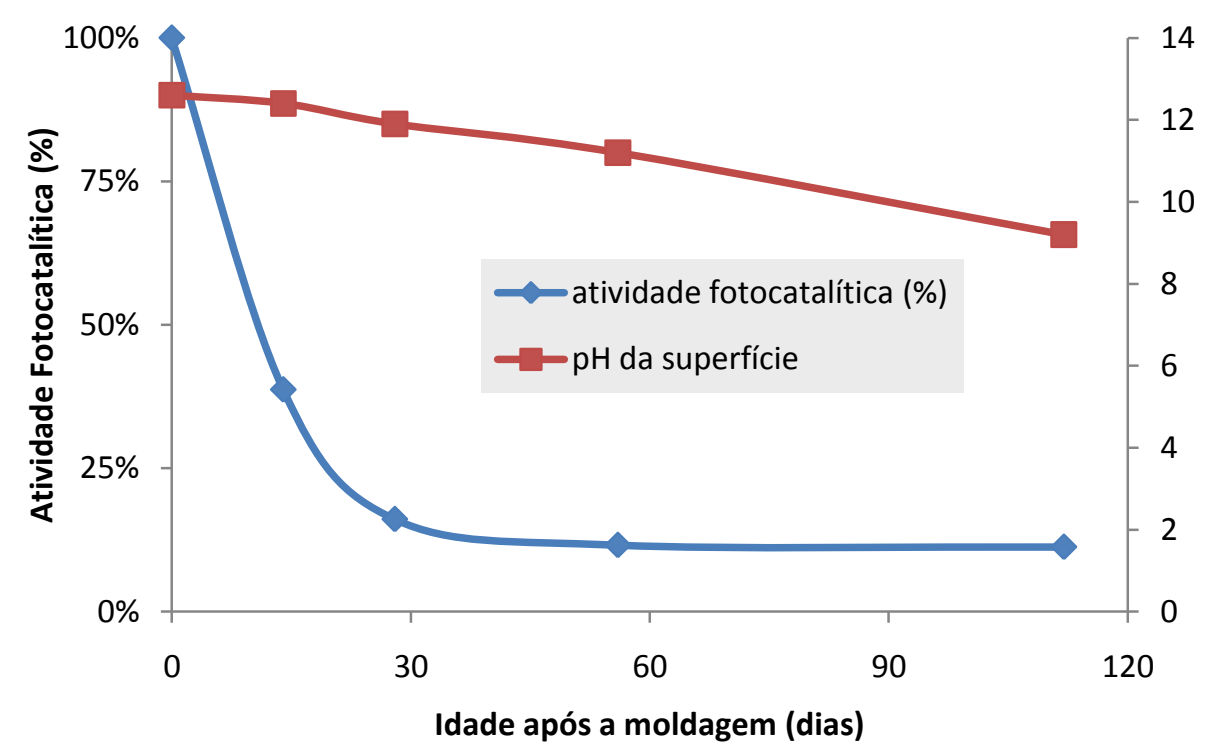

Figura 3- 15: Redução da atividade fotocatalítica após a moldagem de corposde-prova cimentícios. O indicador usado no estudo foi a decomposição de atrazina. Baseado em Lackhoff et. al. (2003).

\subsection{Análise do Capítulo}

Diversas pesquisas e aplicações dos processos fotocatalíticos nos materiais de construção estão sendo desenvolvidas em todo o mundo.

O dióxido de titânio e, em especial, o anatásio é o semicondutor que vem ganhando a maior parte da atenção dos pesquisadores, principalmente porque possui um elevado poder oxidante, por ser encontrado em todo o mundo e não ser tóxico. Esse material quando excitado por uma radiação UV, com comprimento de onda inferior a $385 \mathrm{~nm}$, torna a superfície oxidante e hidrofílica.

Esses dois efeitos, agindo de maneira simultânea, fornecem aos materiais de construção potencial para despoluição do meio ambiente e para transformar a superfície em auto-limpante pela simples ação da chuva e radiação solar.

Ocorre, porém, que a redução do ângulo de contato que a atividade fotocatalítica proporciona provoca um aumento na tensão capilar dos materiais porosos e, consequentemente, pode alterar a cinética de entrada de água e facilitar o desenvolvimento de microorganismos.

Esse fenômeno pôde ser identificado no trabalho de Kurth (2008) onde, com base em ensaios laboratoriais com pinturas cimentícias, identificou-se que as amostras com propriedades fotocatalíticas reduziram em apenas $30 \%$ o crescimento de fungos. Chen et. al (2009) acrescentam, ainda, que, dependendo das condições de umidade, esse efeito pode ser ainda mais reduzido. 
Com base na bibliografia consultada, é possível afirmar que a forma de aplicação mais adequada para os materiais porosos, como granitos, argamassas de revestimento e telhas de fibrocimento sem amianto, objetos de pesquisa desta tese, é o pós-tratamento. Entretanto, apenas com base nas informações colhidas na bibliografia, não é possível estabelecer a concentração ideal de dióxido de titânio nem qual o melhor agente promotor de adesão.

Esses pontos serão abordados na etapa experimental desta tese. 


\section{CAPÍtULO IV}

\section{Avaliação de Alternativas para Obtenção de uma Superfície com Propriedades Fotocatalíticas}

\section{Introduçã̃o}

Conforme destacado nos capítulos anteriores, a produção de uma superfície com propriedades fotocatalíticas nos materiais de construção silicosos e poroso, objeto dessa tese, deve ser realizada como um pós-tratamento com o auxílio de um agente promotor de adesão.

Isto porque, quando adicionado à mistura de materiais cimentícios, provoca um aumento muito significativo no custo, porque o semi-condutor perde poder fotocatalítico à medida que ocorre os fenômenos de hidratação e de carbonatação; e porque quando aplicado como suspensão aquosa apresenta baixa adesão e desprendimento de partículas de dióxido de titânio.

Ocorre, porém, que adesivos orgânicos, como vernizes e acrílicos, são degradados pela atividade fotocatalítica do semi-condutor, gerando fissuras e chalking ao filme polimérico.

Por isso, é necessário criar uma nova forma de criação de superfícies com propriedades fotocatalíticas.

Além disso, em materiais silicosos e porosos aplicados em vedações externas de edifícios, a atividade fotocatalítica não consegue inibir, por completo, o surgimento de manchas porque a cinética de crescimento de fungos é superior à capacidade de degradação desse microorganismo.

Por isso, é necessário que a camada com propriedades fotocatalíticas seja depositada na camada mais externa do material de construção e sob ela seja criada uma superfície com propriedades hidrofóbicas, capaz de reduzir crescimento de microrganismos.

Esta conformação está apresentada na Figura 1- 8 e se constitui na hipótese fundamental desta tese. 


\subsection{Objetivos}

O objetivo deste capítulo é desenvolver um método que forneça à superfície dos materiais de construção silicosos e porosos uma camada com propriedades fotocatalíticas precedidas por uma camada hidrofóbica, utilizando o dióxido de titânio e um hidrofugante à base de silicone.

Para tal, utilizam-se as seguintes premissas:

- ser aplicado como um pós-tratamento: para otimização de dióxido de titânio e porque apenas a camada mais externa é que é foto-ativada pela radiação ultra-violeta

- não necessitar de cura térmica em elevadas temperaturas: para que não cause degradação aos produtos de hidratação, em especial o $\mathrm{CSH}$, que já apresenta degradação a temperaturas abaixo de $100^{\circ} \mathrm{C}$ (Hoppe, 2008) ou ao silicone. Isso possibilita, também, que o produto desenvolvido possa ser aplicado em materiais já em serviço;

- não alterar as características estéticas dos materiais. Isso é relevante porque o dióxido de titânio é um importante pigmento branco;

- apresentar boa aderência ao substrato e suporte processos de abrasão: garantindo durabilidade ao tratamento superficial;

- ser de fácil aplicação: podendo ser aplicado pelo usuário final sem a necessidade de equipamentos e ferramentas especiais.

\subsection{Hipótese Experimental}

Quando disperso em água, o $\mathrm{TiO}_{2}$ apresenta uma hidrólise superficial formando $\mathrm{Ti}(\mathrm{OH})$ de maneira similar à proposta por Chen; Poon (2009) e ilustrado na Figura 41. Isso faz com que uma suspensão aquosa apresente uma adesão fraca se for aplicada diretamente sobre substratos silicosos e porosos. Por isso, é necessário o uso de um agente de ligação para garantir o desempenho a longo prazo.

Por sua vez, os hidrofugantes à base de silicone apresentam bom potencial de se tornarem agentes de ligação, visto que, durante o seu processo de hidrólise geram radicais silanol $(\mathrm{SiOH})$ capazes de se ligar à superfície do dióxido de titânio hidrolisada e aos materiais de construção silicosos e porosos de maneira efetiva. Toda essa seqüência está apresentada de maneira sequencial nas Figura 4- 2 a Figura 4- 4.

Como consequência desse processo, o dióxido de titânio fica ligado a uma matriz de $\mathrm{Si}-\mathrm{O}-\mathrm{Si}$ e sobre os radicais hidrofóbicos, permitindo sua foto-ativação quando incidido por radiação ultravioleta.

Conforme já destacado, o radical silanol já vem sendo com sucesso como agente de ligação das partículas de dióxido de titânio sobre filmes poliméricos, sendo que, nesses casos, sua origem está na sílica coloidal depositada pelo método de sol-gel (Cai et. al., 2006 e Yuranova et. al., 2007). Aqui, sua origem está no hidrofugante. 

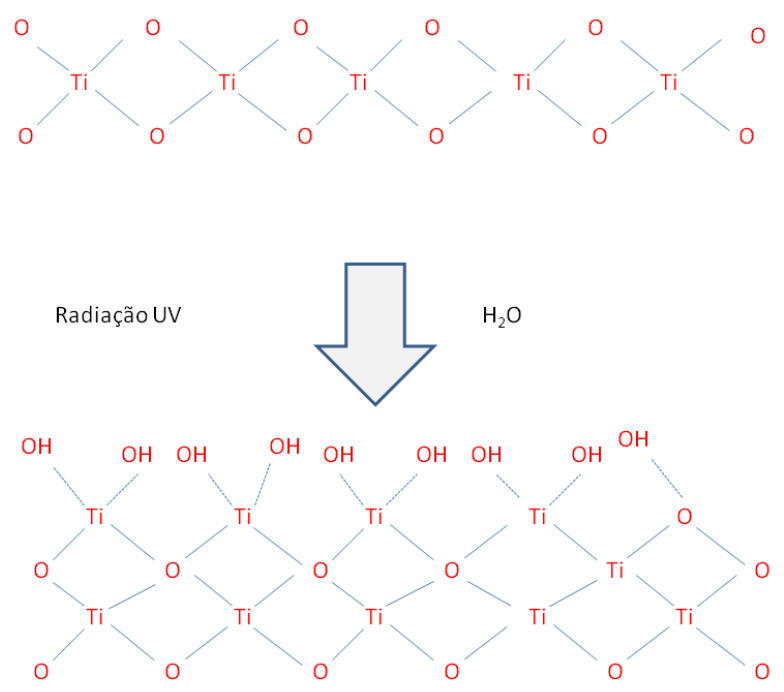

Figura 4- 1: Hidrólise superficial das partículas de dióxido de dióxido de titânio. Baseado em Chen; Ponn (2009).

Esse tipo de superfície atende à hipótese fundamental desta tese, apresentada no item 1.4 do Capítulo 1. Além disso, pode ser generalizado para qualquer material de construção porosos e silicosos porque o mecanismo de adesão do produto à base de silicone é semelhante e porque a ligação entre o dióxido de titânio e o hidrofugante não depende das propriedades da base

1. Passo: hidrólise do hidrofugante

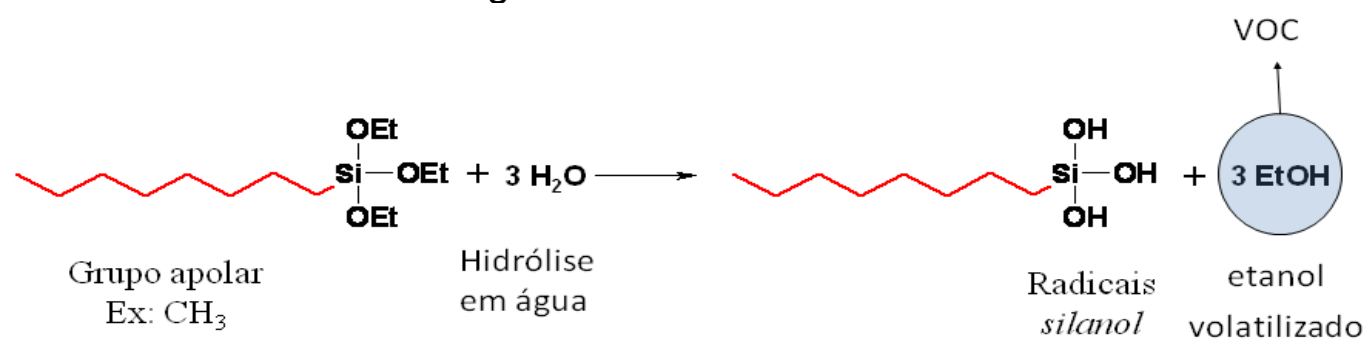

Figura 4- 2: Processo de hidrólise de hidrofugante genérico à base de silicone. 
2. Passo: mecanismo de fixação do hidrofugante à superfície do substrato e o posicionamento dos radicais hidrofóbicos e silanol

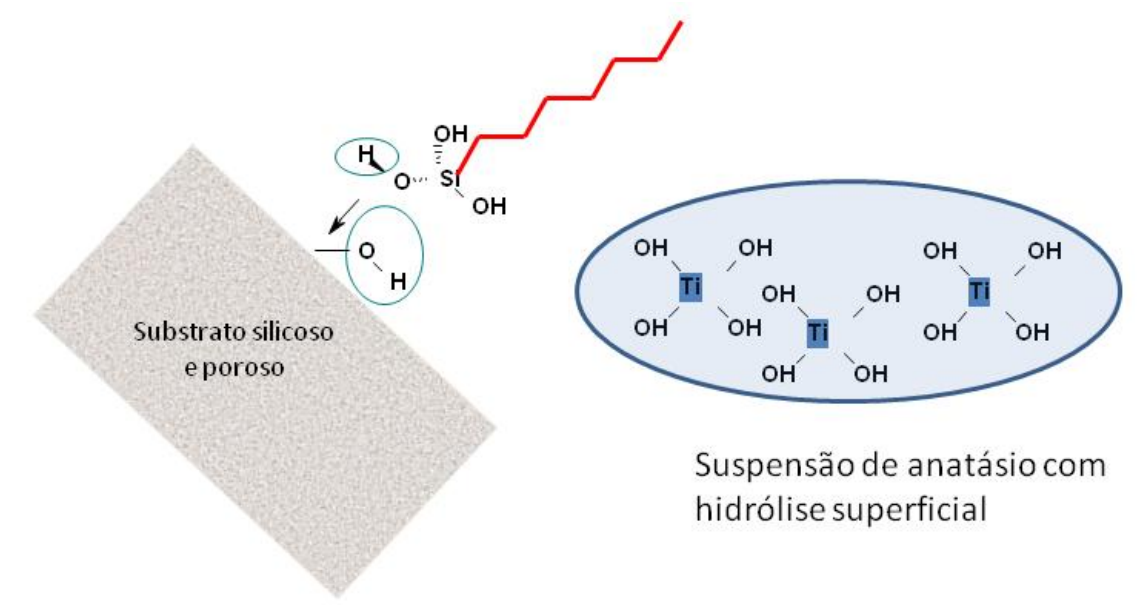

Figura 4- 3: Processo de condensação do hidrofugante à base de silicone e ligação aos substratos silicosos e porosos.

3. Passo: ligação das partículas de dióxido de titânio hidrolisada ao radical silanol com a liberação de água

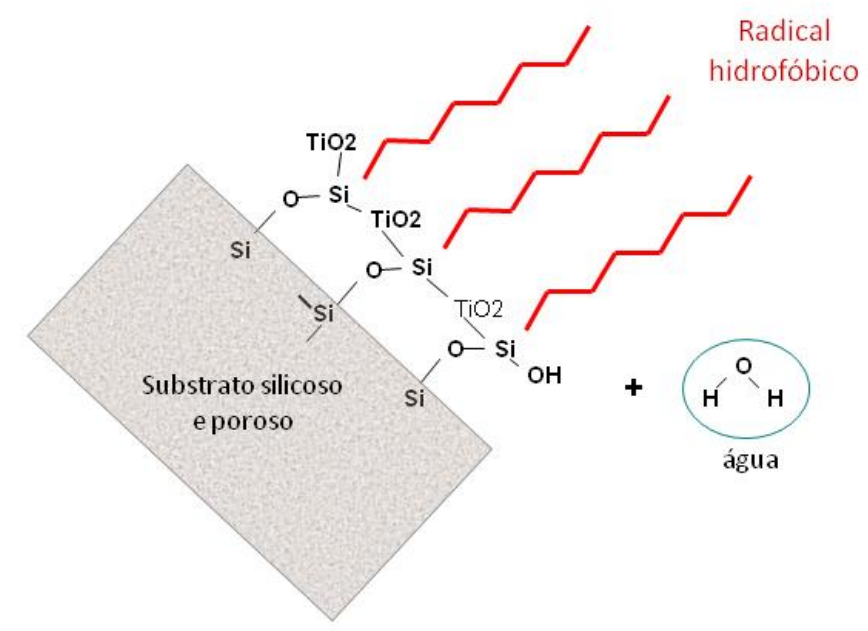

Figura 4- 4: fixação do hidrofugante à base de silicone nos substratos silicosos e porosos na presença de solução de anatásio

\subsection{Planejamento Experimental}

Para testar a hipótese experimental e atender às premissas estabelecidas é utilizado o planejamento experimental descrito na Figura 4- 5, que é dividido em três etapas.

A primeira etapa avalia a concentração máxima que o dióxido de titânio pode ser aplicado, em forma de suspensão aquosa, na superfície de um material de 
construção silicoso e poroso, com os métodos de dispersão e aplicação utilizados nessa tese, de forma que não provoque manchas esbraquiçadas.

A segunda etapa avalia a consequencias da união entre o hidrofugante e o dióxido de titânio na atividade fotocatalítica quando incididos por radiação UV. Isso é feito por meio da medição da cinética do ângulo de contato em substratos de vidro e cerâmicas, antes e depois de ciclos de abrasão. Ressalta-se que a avaliação do ângulo de contato é um método bastante utilizado para avaliação de produtos fotocatalíticos.

A terceira e última etapa avalia a capacidade do silicone ser usado como agente de ligação entre este semicondutor e os substratos silicosos e porosos, por meio de avaliações microestruturais de MEV e de FTIR. Nessa etapa, busca-se identificar a possível ligação química entre o silicone e o titânio (Si-O-TI), como apresentado no item anterior) e o impacto que o uso de silicone provoca na forma deposição do semicondutor e resistência à abrasão do tratamento superficial.

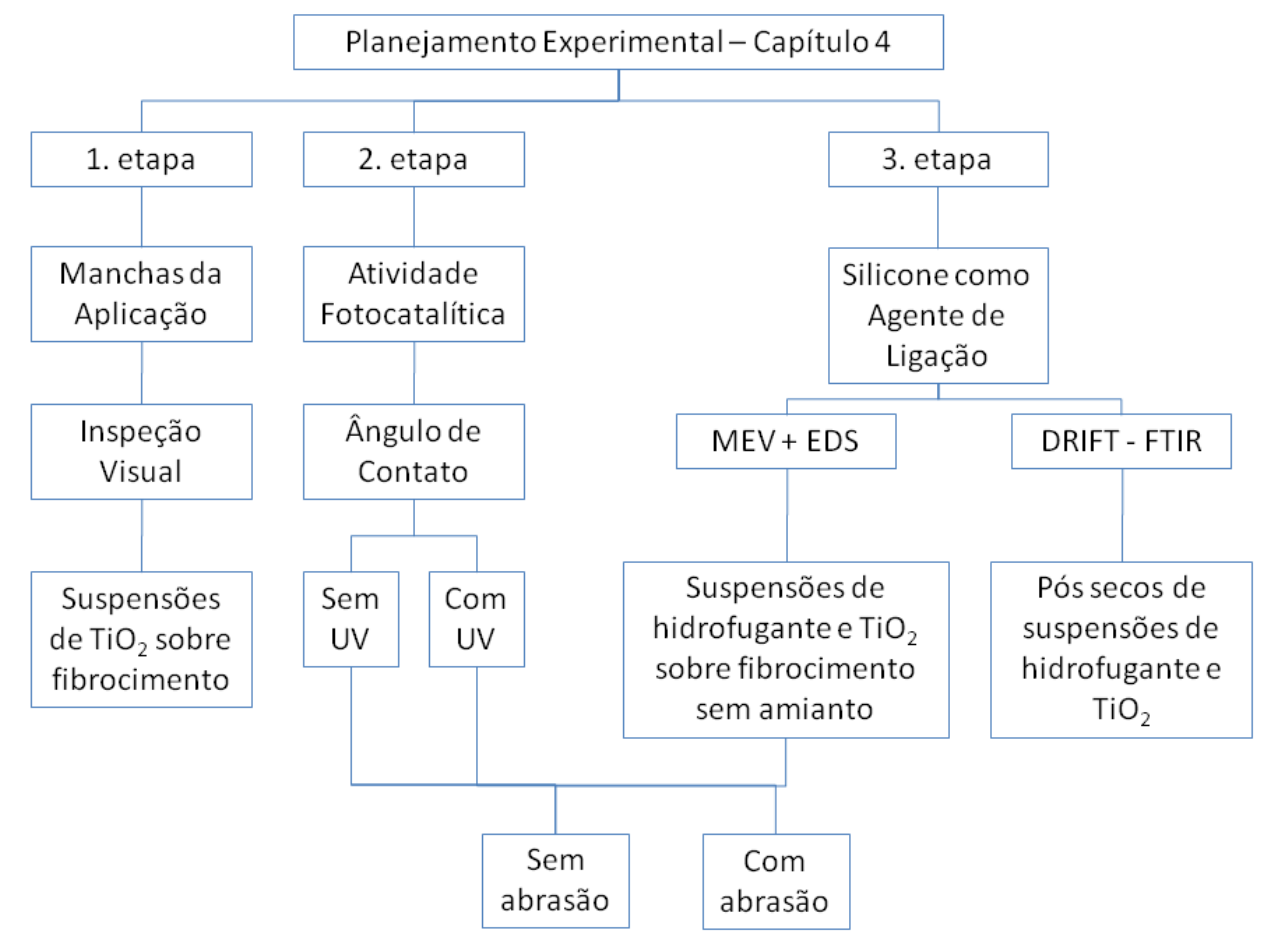

Figura 4- 5: Planejamento experimental para a avaliação de superfícies com propriedades fotocatalíticas.

\subsubsection{Materiais}

Para atingir os objetivos propostos foram utilizados:

- Dióxido de titânio: anatásio P-25 da Evonik, que segundo o fabricante, é constituído por $70 \%$ de anatásio e $30 \%$ de rutilo, e possui uma área superficial BET superior a $55 \pm 15 \mathrm{~m}^{2} / \mathrm{g}$.

A composição mineralógica foi confirmada em caracterização realizada por difratometria de Raios- $X$, realizada no Laboratório de Caracterização Tecnológica do Departamento de Minas e Petróleo da EP-USP (anexo A). 
O tamanho de partícula, porém, apresentou resultados diferentes (Figura 4- 6). O produto avaliado apresentou granulometria mais grosseira com um $D(10)$ de $0,30 \mu \mathrm{m}$ e um $\mathrm{D}(50)$ de $2,69 \mu \mathrm{m}^{10}$. Essa distribuição é semelhante à encontrada por Tan (2004) quando avaliou o mesmo produto.

Duas possíveis explicações para este resultado são: (i) o método de dispersão utilizado foi insuficiente e os valores referem-se a aglomerados de partículas; ou (ii) o produto utilizado é diferente do especificado pelo fabricante.
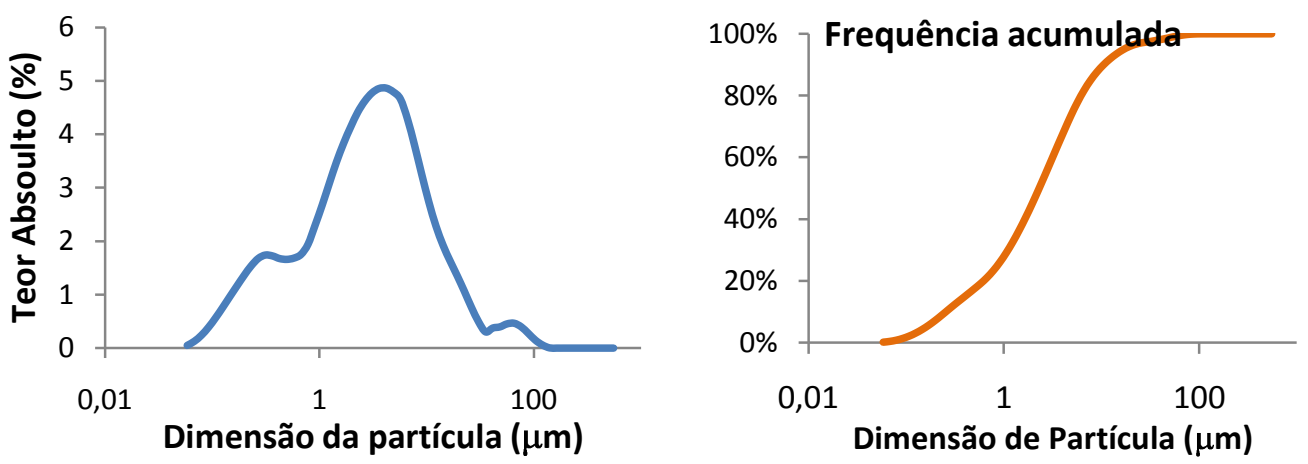

Figura 4- 6: Caracterização do tamanho de partícula da solução do anatásio utilizado no programa laboratorial.

- Substratos: telhas de fibrocimento sem amianto (vinte corpos-de-prova já carbonatados), cerâmica à base de alumina (trinta e seis corpos-de-prova) e placas de vidro (cinco corpos-de-prova).

Este último foi escolhido por ser silicoso e não-poroso, possibilitando o mesmo mecanismo de adesão do silanol e facilitando as medições que são influenciadas pela absorção d'água.

- Hidrofugante: octiltrietoxisilano solúvel em água com uma concentração de $10 \%$, em relação à massa de água. Este produto e essa concentração foram escolhidos após um longo programa de investigação laboratorial em parceria com a empresa Dow Corning Corporation, cujo objetivo foi avaliar o uso de hidrofugantes em fibrocimentos sem amianto.

Como principais resultados é possível afirmar que a concentração de 10\% foi suficiente para reduzir em mais de $60 \%$ a absorção de água após 24 horas de imersão (Figura 4- 7) e que um envelhecimento artificial acelerado, com 150 ciclos de aquecimento e molhagem, não provocaram qualquer tipo de alteração significativa no comportamento.

Maiores informações sobre toda a investigação realizada dos resultados e mesmo sobre esse produto podem ser encontrados em publicações como:

\footnotetext{
${ }^{10}$ Os ensaios foram realizados em um granulômetro a laser da marca Malvern modelo Mastersizer Microplus versão 2.19 e as interpretações dos resultados foram feitas pelo software do próprio equipamento. Anteriormente aos ensaios, as suspensões aquosas passaram por processos de dispersão com o ultrasom do próprio equipamento por 1 minuto. $O$ aprofundamento dessas questões extrapola aos objetivos desta tese.
} 
a) Performance of Silicone Water Repellent for FRC Corrugated Roof Tiles, publicado no 11th International Conference on Durability of Building Materials and Components, Istambul, Turquia, 2008

b) Silicone water repellents for (FRC) Fiber-Cement Boards. Apresentado no 10th International Inorganic Bonded Composite Materials Conference, São Paulo, Brasil 2006.

c) O uso de hidrofugantes em materiais de construção porosos. Revista Techne, dezembro, 2009 (no prelo)

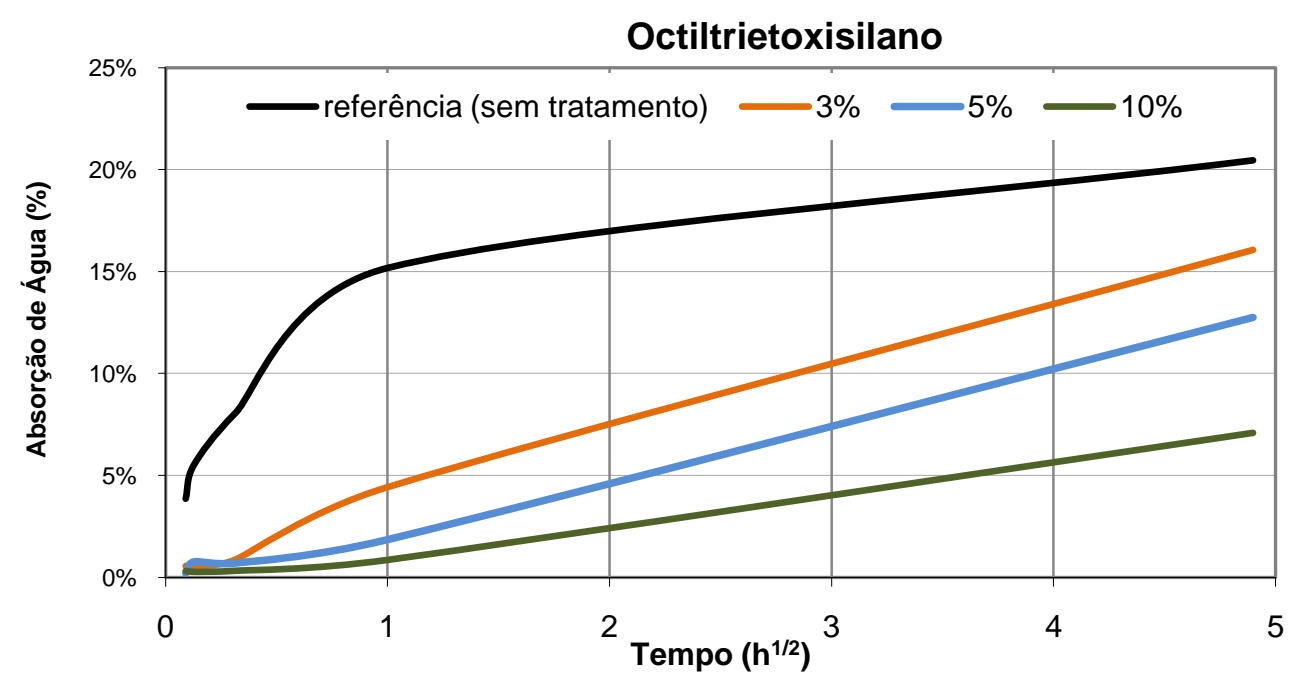

Figura 4- 7: Cinética de absorção d'água para os corpos-de-prova de fibrocimento sem-amieto ao longo de 24 horas de imersão. (Maranhão et.al, 2008).

- Aplicacão dos tratamentos superficiais: os tratamentos superficiais usados na tese foram), suspensão aquosa de dióxido de titânio, solução de hidrofugante, suspensão de dióxido de titânio + hidrofugante. Além desse, foi avaliada as superfícies sem tratamento, que foram usadas como referência.

As soluções e suspensões foram preparadas pela adição dos produtos ativos à água, seguida de mistura manual por 30 minutos.

Todas as aplicações foram realizadas de forma manual com o auxílio de um pincel e sem nenhum tipo de cura posterior. Anteriormente ao tratamento, todas as superfícies foram limpas com um pano umedecido em água apenas para a retirada de impurezas ou pó depositados.

O tratamento composto por dióxido de titânio + hidrofugante foi aplicada de duas maneiras:

- simultânea - onde a solução contendo o agente hidrofugante e o dióxido de titânio foram misturados previamente, e a aplicação aconteceu em uma única etapa. Para sua identificação, nessa tese é utilizada a nomenclatura $\mathrm{WR}+\mathrm{TiO}_{2 \text {-simultâneo; }}$

- sequencial: onde o agente hidrofugante foi aplicado primeiramente e, sobre ele, aplicou-se uma suspensão de dióxido de titânio. O tempo entre as duas aplicações foi de um minuto. Para sua identificação, nessa tese é usada a nomenclatura $\mathrm{WR}+\mathrm{TiO}_{2 \text {-sequencial. }}$ 


\subsubsection{Mếtodos}

Os métodos de avaliação utilizados foram: MEV, ângulo de contato e Espectrofotometria de Infravermelho por Transformada de Fourier, pela técnica de DRIFT e ATR. Cada um deles foi utilizado em uma etapa da pesquisa.

A abrasão superficial foi realizada com o equipamento preconizado pela NBR 15.078 (ABNT, 2005) destinada à avaliação de resistência à abrasão de tintas. O ensaio foi realizado com água e sem abrasivos, e a quantidade de cem ciclos utilizada corresponde ao mínimo especificado para as tintas do tipo látex econômico (Figura 4- 8).
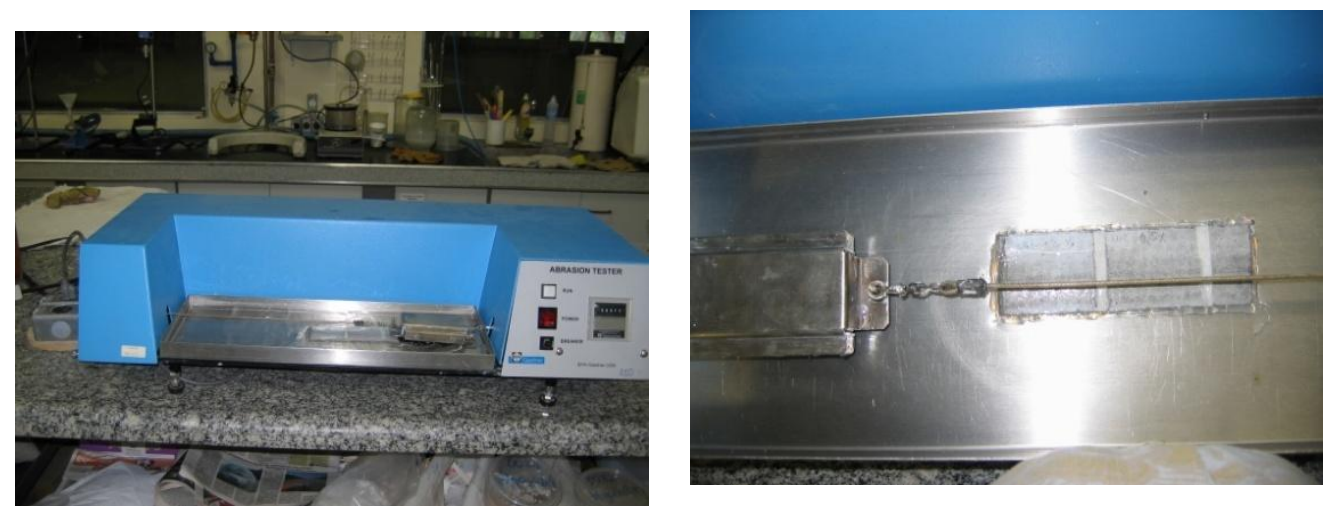

Figura 4- 8: llustração do equipamento utilizado para realizar a ciclos de abrasão dos corpos-de-prova.

\subsubsection{Manchas da Aplicação}

A avaliação das manchas esbranquiçadas causadas pela aplicação do semicondutor sobre substratos porosos e silicosos foi realizada por meio de inspeção visual em placas de fibrocimento sem amianto. Para tal, as concentrações de $\mathrm{TiO}_{2}$ utilizadas foram de $0,10 \%, 0,25 \%, 0,50 \%, 1,0 \%$ e $2,0 \%$, medidos em relação à massa de água.

Após os tratamentos, os corpos-de-prova foram secos em estufa ventilada por duas horas a $40^{\circ} \mathrm{C}, 60^{\circ} \mathrm{C}$ e $100^{\circ} \mathrm{C}$, seguidos de lavagem manual apenas para retirada de excessos, e nova secagem em estufa por mais duas horas.

A aplicação das suspensões foi feita por meio de pinturas manuais com pincel.

\subsubsection{Atividade Fotocatalítica}

A atividade fotocatalítica foi avaliada por meio de análises comparativas entre os resultados do ângulo de contato antes e depois da exposição dos corpos-de-prova à radiação ultravioleta (UV-A). Para tal, foi utilizado um goniômetro da marca Kruss, modelo DSA 100, existente no Laboratório de Microestrutura do Departamento de Construção Civil da EP-USP. O líquido utilizado foi a água deionizada com um volume de gota de $1,0 \mu \mathrm{L}$ e as medições foram realizadas ao longo de 2 minutos, 
contados a partir da sua deposição na superfície dos corpos-de-prova. Para cada amostra foram ensaiadas, pelo menos, dezesseis diferentes gotas (Figura 4- 9).

O tempo entre a deposição da gota e a primeira medição foi de, aproximadamente, três segundos, necessários para ajustes de foco e da linha base. Apesar de ser um equipamento automatizado, a medição propriamente dita é feita de forma manual, razão pela qual não foi possível controlar os tempos de aquisição para todas as amostras.

A radiação ultravioleta consistiu em quatro a cinco dias de exposição a quatro lâmpadas UV-A, com potência de $8 \mathrm{~W}$ e mais de 3000 horas de uso, distantes $10 \mathrm{~cm}$ da face dos corpos-de-prova. Todos os testes foram realizados em ambiente onde a temperatura e umidade são controlados a $23^{\circ} \mathrm{C}$ e $50 \%$, respectivamente.

Os substratos ensaiados foram a cerâmica e placas de vidro. Ambos receberam os seguintes tratamentos superficiais: hidrofugante na concentração de $10 \%$ em massa (WR); suspensão aquosa de dióxido de titânio na concentração de 1,0\% em massa $\left(\mathrm{TiO}_{2}\right)$; e mistura de hidrofugante $(10 \% \mathrm{w} / \mathrm{w})$ e dióxido de titânio $(1,0 \% \mathrm{w} / \mathrm{w})$ aplicada em uma demão e duas demãos $\left(\mathrm{WR}+\mathrm{TiO}_{2}\right.$-simultâneo e $\mathrm{WR}+\mathrm{TiO}_{2 \text {-sequencial, }}$ respectivamente). Todos foram aplicados com o auxílio de um pincel e sem nenhum tipo de cura térmica.

As avaliações foram realizadas em corpos-de-prova antes e depois de sofrerem ciclos de abrasão superficial.

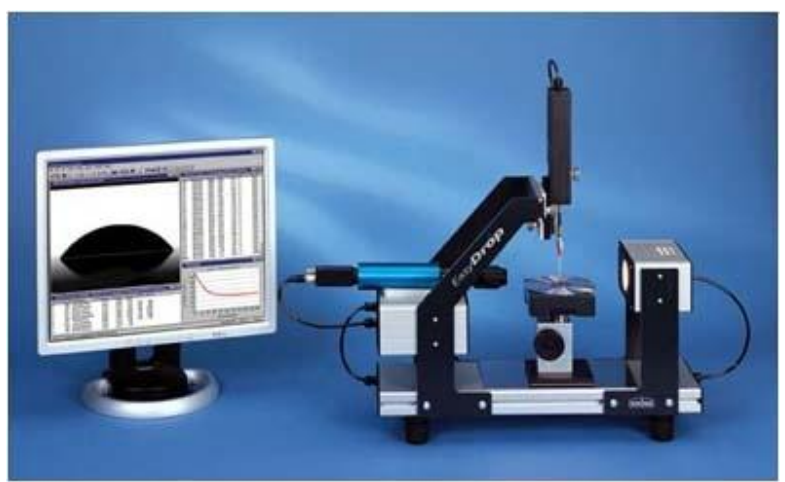

(a)

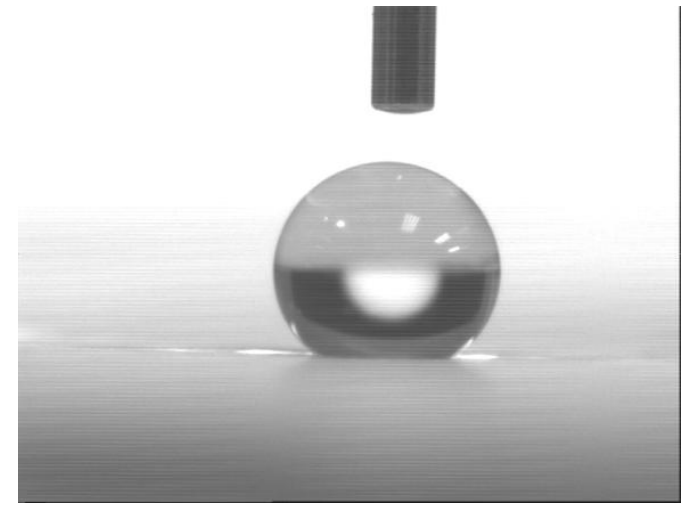

(b)

Figura 4- 9: (a) Goniômetro utilizado para a avaliação do ângulo de contato e (b) Exemplo de resultado obtido na avaliação do ângulo de contato.

\subsubsection{Silicone como Agente de Ligação do Dióxido de Titânio}

A avaliação do impacto do uso de hidrofugantes à base de silicone como agente de ligação entre o substrato silicoso e poroso e o semicondutor foi realizado por meio de Microscopia Eletrônica de Varredura (MEV) e de da Espectroscopia de Infravermelho por Transformada de Fourier (FTIR).

a) FTIR 
O FTIR foi usado para a identificação da possível ligação química entre o dióxido de titânio e o silicone (Ti-O-Si), conforme idealizado na hipótese experimental apresentado no item 4.2 .

Para tal, foi utilizada a técnica de DRIFT da Espectroscopia de Infravermelho por Transformada de Fourier, com um Magna 560 com célula DRIFT da Nicolet Instrument Corporation, existente no Laboratório de Processos Cerâmicos de Departamento de Engenharia de Materiais da EP-USP. A faixa de varredura foi de $400 \mathrm{~cm}^{-1}$ a $4000 \mathrm{~cm}^{-1}$.

As avaliações foram realizadas de maneira comparativa entre amostras em que se variou os teores de dióxido de titânio e de hidrofugantes (Tabela 3). Todas foram preparadas com água deionizada e deixadas em um Becker de vidro por 24 horas para depois secarem em uma estufa ventilada a $60^{\circ} \mathrm{C}$ por 24 horas. Por último, 0 material foi raspado, comuído em um almofariz de ágata e ensaiado.

Tabela 3: Amostras utilizadas nos ensaios de FTIR para a avaliação da ligação química entre o silicone e o dióxido de titânio.

\begin{tabular}{l|c|c} 
Nomenclatura da amostra & Teor de dióxido de titânio na suspensão & Teor de hidrofugante \\
\hline $10,0 \%$ & $10 \%$ & $0 \%$ \\
\hline Wr1 (10\%) & $0 \%$ & $10 \%$ \\
\hline Wr1 (10\%)+ tio2 (5\%) & $5 \%$ & $10 \%$ \\
\hline Wr1 (10\%)+ tio2 (10\%) & $10 \%$ & $10 \%$ \\
\hline Wr1 (10\%)+ tio2 (50\%) & $10 \%$ & $50 \%$
\end{tabular}

Apenas a amostra de silicone sem adição de dióxido de titânio foi avaliada pela técnica de ATR com o mesmo equipamento supracitado. Isso foi necessário porque, durante a etapa exploratória desta tese, o DRIFT não apresentou resultados satisfatórios.

B) MEV

As avaliações microscópicas foram realizadas em um microscópio eletrônico de varredura FEI, modelo Quanta 600 FEG com espectrômetro de dispersão de energia (EDS) da Bruker, com software para microanálise, Sprit, também da Bruker, existente no Laboratório de Caracterização Tecnológica do Departamento de Minas e Petróleo da EPUSP.

Todas as avaliações foram realizadas sobre corpos-de-prova de fibrocimento sem amianto, com os diferentes tratamentos superficiais, com dimensões de $1,0 \mathrm{~cm} x$ $1,0 \mathrm{~cm}$, sendo que em cada um deles, foram realizadas cinco leituras do EDS conforme apresentado na Figura 4- 10. Todas essas leituras foram realizadas com um aumento de 2000X.

As análises semi-quantitativas foram feitas com a intensidade do primeiro pico do titânio identificado no EDS.

As amostras utilizadas estão apresentadas na Tabela 4. 
Tabela 4: Amostras usada na Microscopia Eletrônica da Varredura (MEV).

\begin{tabular}{c|c|c} 
Teor de Hidrofugante & $\begin{array}{c}\text { Teor de dióxido de } \\
\text { titânio na suspensão }\end{array}$ & $\begin{array}{c}\text { Ciclos de } \\
\text { Abrasão }\end{array}$ \\
\hline$O \%$ & $0 \%$ & Não \\
\hline$O \%$ & $0 \%$ & Sim \\
\hline$O \%$ & $0,50 \%$ & Não \\
\hline $0 \%$ & $0,50 \%$ & Sim \\
\hline $10 \%$ & $0,50 \%$ & Não \\
\hline $10 \%$ & $0,50 \%$ & Sim \\
\hline $0 \%$ & $1,0 \%$ & Não \\
\hline$O \%$ & $1,0 \%$ & Sim \\
\hline $10 \%$ & $1,0 \%$ & Não \\
\hline $10 \%$ & $1,0 \%$ & Sim \\
\hline$O \%$ & $2,0 \%$ & Não \\
\hline$O \%$ & $2,0 \%$ & Sim \\
\hline $10 \%$ & $2,0 \%$ & Não \\
\hline $10 \%$ & $2,0 \%$ & Sim
\end{tabular}

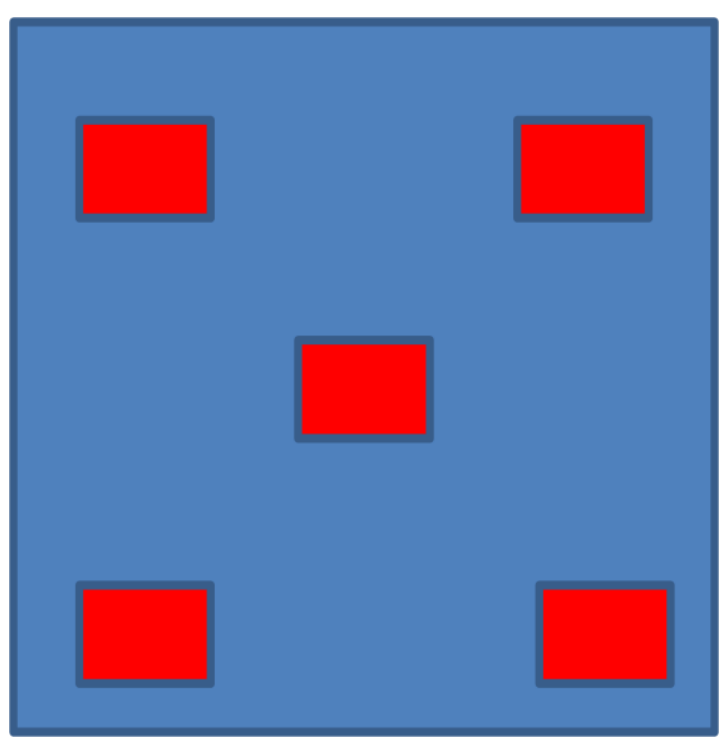

Figura 4- 10: Esquema da rotina de leitura utilizada no MEV.

\subsection{Avaliaçã̃o dos Resultados}

\subsubsection{Manchas da Aplicação}

Na Figura 4- 11 estão apresentados os resultados obtidos em placas de fibrocimento após a aplicação da suspensão de $\mathrm{TiO}_{2}$ como pós-tratamento e secadas a $40^{\circ} \mathrm{C}$, $60^{\circ} \mathrm{C}$ e $100^{\circ} \mathrm{C}$.

Como é possível observar, à medida que a concentração de $\mathrm{TiO}_{2}$ aumenta, percebese a formação de uma camada esbranquiçada na superfície do substrato. Teores inferiores a $0,50 \%$ não provocaram qualquer tipo de influência, e o teor de 2,0\% provocou manchas de elevada intensidade e uniformidade. O teor de $1,0 \%$ provocou 
manchas não uniformes e que foram totalmente retiradas após a lavagem manual (Figura 4- 12).

Essas manchas são causadas, possivelmente, pela deposição não uniforme de aglomerados do semicondutor, que após a lavagem manual desaparecem. Isso é consequência da baixa adesão que uma suspensão de dióxido de titânio apresenta à substratos porosos e silicosos, conforme previamente destacado no item $1.2 \mathrm{e}$ constatado por Diamanti et. al. (2008).

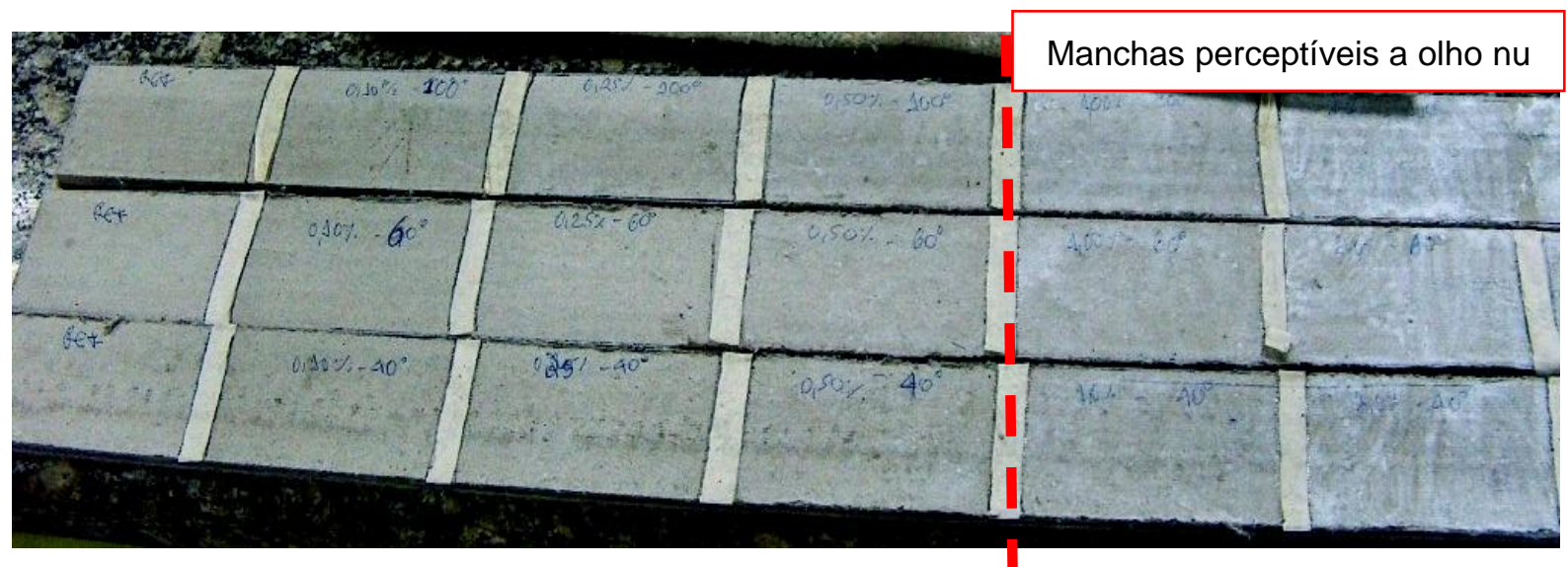

Sem $\mathrm{TiO}_{2} \quad 0,10 \%-\mathrm{TiO}_{2} \quad 0,25 \%-\mathrm{TiO}_{2} \quad 0,50 \%-\mathrm{TiO}_{2} \quad 1,0 \%-\mathrm{TiO}_{2} \quad 2,0 \%-\mathrm{TiO}_{2}$

Consumo

$\begin{array}{llllll}\text { de } \mathrm{TiO}_{2} & 0,61 & 1,52 & 3,05 & 6,1 & 12,2 \\ \left(\mathrm{~g} / \mathrm{m}^{2}\right) & & & & \end{array}$

Figura 4- 11: Aspecto visual de placas de fibrocimento em função do aumento da concentração de $\mathrm{TiO}_{2}$, em relação à massa de água. 


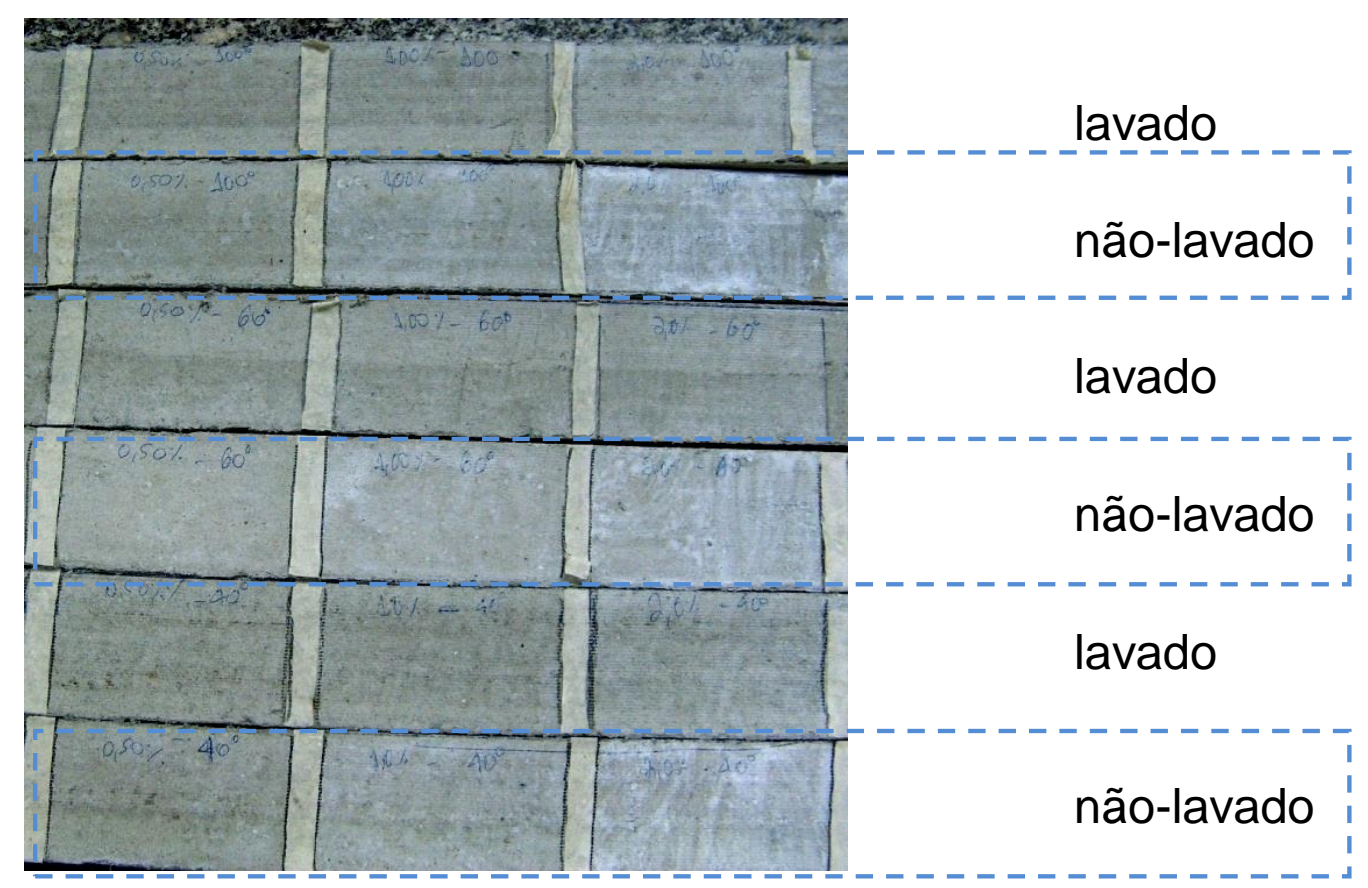

Figura 4- 12: Detalhe do aspecto visual das placas de fibrocimento antes e depois da lavagem manual.

\subsubsection{Atividade fotocatalitica}

Para facilitar o entendimento, os resultados da atividade fotocatalítica, medido pela variação do ângulo de contato, são divididos segundo o tipo de substrato avaliado: primeiramente o vidro e depois a cerâmica.

\section{a) Vidro}

A amostra de referência (sem tratamento) apresentou ângulos de contato inicial médio de $20^{\circ}$, e não foi influenciada pelos ciclos de abrasão e pela a incidência de radiação ultravioleta.

Nas amostras com tratamentos superficiais (Figura 4- 13), a abrasão também exerceu poucas influências nos resultados, sendo que a única diferença importante foi constatada na amostra $\mathrm{TiO}_{2}$, onde o ângulo de contato foi reduzido de $100^{\circ}$ para $16^{\circ}$. A explicação o para elevado ângulo de contato antes da abrasão está ligada, possivelmente, ao procedimento de preparação dos corpos-de-prova que possibilitou uma contaminação com o produto hidrofugante. Após o ciclo de abrasão, o comportamento se tornou semelhante à referência, como é de esperar.

Outro ponto que chama a atenção é que o tratamento com hidrofugante e dióxido de titânio aplicados de maneira sequencial $\left(\mathrm{WR}+\mathrm{TiO}_{2}\right.$-sequencial $)$ apresentou um aumento no ângulo de contato inicial, tanto antes quanto depois do ciclo de abrasão, quando comparado aos demais tratamentos. A explicação para este fenômeno não está clara e foge aos objetivos desta tese; porém, os valores superiores a $140^{\circ}$ dão a entender que uma micro-rugosidade tenha surgido na superfície, de maneira análoga à existente nos super-hidrofugantes e nas folhas de lótus. 

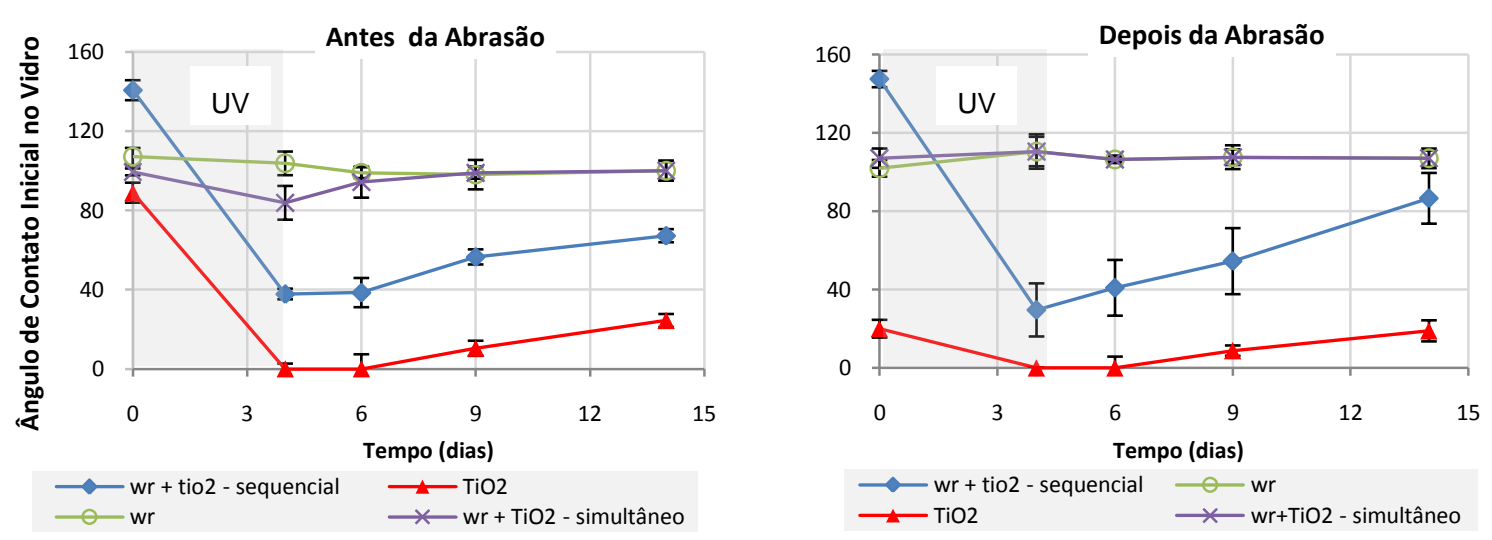

Figura 4- 13: Médias do ângulo de contato inicial antes e depois dos ciclos de abrasão, em substratos de vidros. Para cada ponto foram realizadas, no mínimo, dezesseis medições.

Comparando os resultados anteriores e posteriores à exposição à radiação ultravioleta (tempo zero e quatro dias), percebe-se que apenas as amostras $\mathrm{TiO}_{2}$ e $\mathrm{WR}+\mathrm{TiO}_{2}$-sequencial foram influenciadas. Na primeira, o ultravioleta provocou o surgimento de lâminas d'água com ângulos de contato nulos, enquanto que na segunda houve uma redução de $140^{\circ}$ para valores inferiores a $40^{\circ}$ (Figura 4- 13). Essa última amostra, por sinal, foi a que apresentou a maior dispersão nos resultados, como consequencia de uma deposição não uniforme do semicondutor na superfície do substrato, conforme já constatado no item anteriore.

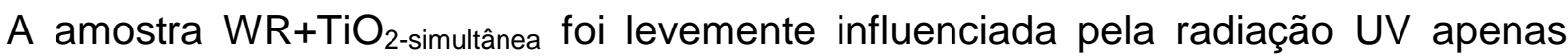
antes da abrasão, caracterizada por uma redução do ângulo de contato de $100^{\circ}$ para $93^{\circ}$. Esse comportamento também pode ser atribuído a uma inadequada deposição do tratamento superficial no substrato, fazendo com que existissem pontos onde o dióxido de titânio não estivesse completamente recoberto pelo hidrofugante, e se tornasse fotoativado.

Dentre todos os tratamentos avaliados, apenas a amostra de $\mathrm{WR}+\mathrm{TiO}_{2 \text {-sequencial }}$ apresentou aumentos significativos no ângulo de contato após a exposição ao UV, sendo, por exemplo, de $30^{\circ}$ para $86^{\circ}$ depois da abrasão. Apesar disso, mesmo após dez dias os corpos-de-prova ainda apresentavam características hidrofílicas, com ângulos de contato inferiores a $90^{\circ}$.

Um ponto que chama a atenção é esse progressivo retorno da hidrofobicidade não se dá de maneira uniforme. Umm exemplo disso, é o resultado após 120horas, onde alguns pontos apresentam a ângulo de contato inferiores a $90^{\circ} \mathrm{e}$ outros superiores a $90^{\circ}$. Apesar de não haver uma prova clara, esse tipo de comportamento pode ser atribuído a um recobrimento parcial das partículas de dióxido de titânio.

Por não ser um material poroso, o vidro não apresentou alteração do ângulo de contato ao longo dos dois minutos de ensaio em todas as amostras avaliadas (Figura 4- 14). 


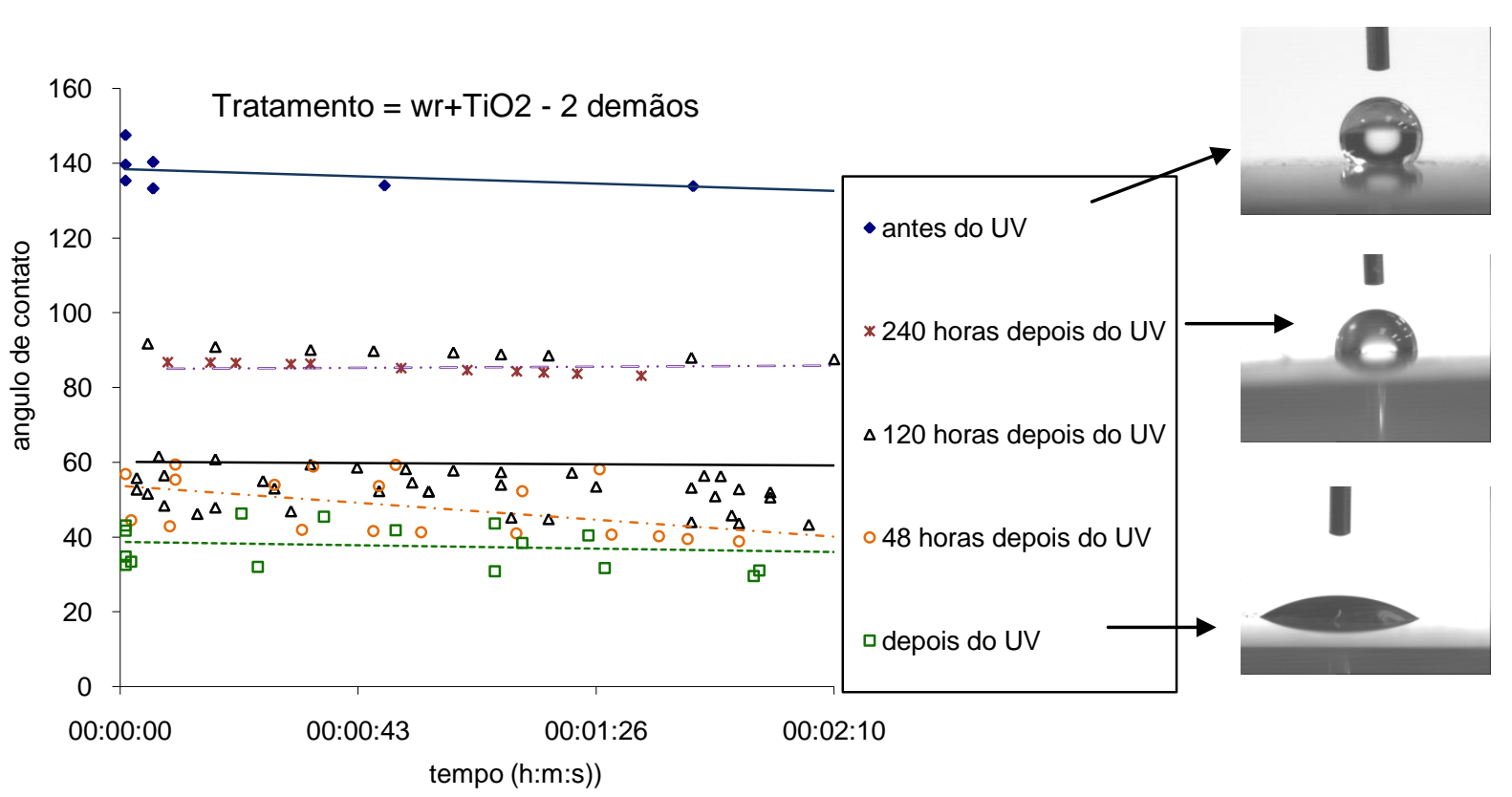

Figura 4- 14: Variação característica do ângulo de contato de um corpo-de-prova no

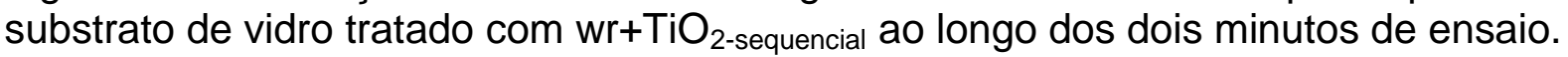

\section{b) Cerâmica}

A amostra de referência (sem nenhum tipo de tratamento) apresentou ângulos de contato inicial máximos de $24^{\circ}$, seguidos de uma rápida redução logo nos primeiros segundos. Não se identificou qualquer tipo de alteração nesse comportamento causada pelos ciclos de abrasão e pela exposição à radiação UV.

O tratamento superficial com apenas uma suspensão aquosa de dióxido de titânio (aqui denominado por $\mathrm{TiO}_{2}$ ) foi fortemente influenciada pela incidência da radiação ultravioleta (Figura 4- 15), fazendo com que o ângulo de contato inicial fosse reduzido de $40^{\circ}$ para zero. Este comportamento foi observado tanto antes quanto depois dos ciclos de abrasão, e pode ser atribuído à foto-ativação do semicondutor e ao aumento da sua hidrofilicidade (Irie;Hashimoto, 2005).

Os corpos-de-prova tratados com hidrofugante (denominado por WR) e a união do hidrofugante e dióxido de titânio, aplicados em uma única demão ( $\left.\mathrm{WR}+\mathrm{TiO}_{2 \text {-simultâneo }}\right)$, apresentaram comportamentos semelhantes (Figura 4- 15), tanto antes como depois dos ciclos de abrasão. Todos os resultados foram superiores a $100^{\circ}$ e a incidência de radiação ultravioleta não provocou alteração. Esses resultados são semelhantes aos obtidos com o vidro, e confirmam que não há foto-ativação nesses tratamentos.

Já quando o hidrofugante e dióxido de titânio são aplicados separadamente $\left(\mathrm{WR}+\mathrm{TiO}_{2 \text {-sequencial }}\right)$, observou-se um comportamento diferente: anteriormente à incidência de radiação ultravioleta o ângulo de contato inicial foi superior a $115^{\circ} \mathrm{e}$ depois inferior a $60^{\circ}$, tanto antes como depois dos ciclos de abrasão.

Isso comprova que esse tipo de tratamento foi fortemente influenciado pela incidência de radiação ultravioleta, provocando reduções superiores a $50 \%$ no valor do ângulo de contato inicial (imediatamente após à exposição à radiação UV). Os 
resultados aqui apresentados estão concordantes com Diamanti et. al. (2008), quando se utilizaram substratos de argamassa aditivados com $\mathrm{TiO}_{2}$ durante a mistura, e tempo de exposição à radiação ultravioleta semelhante.
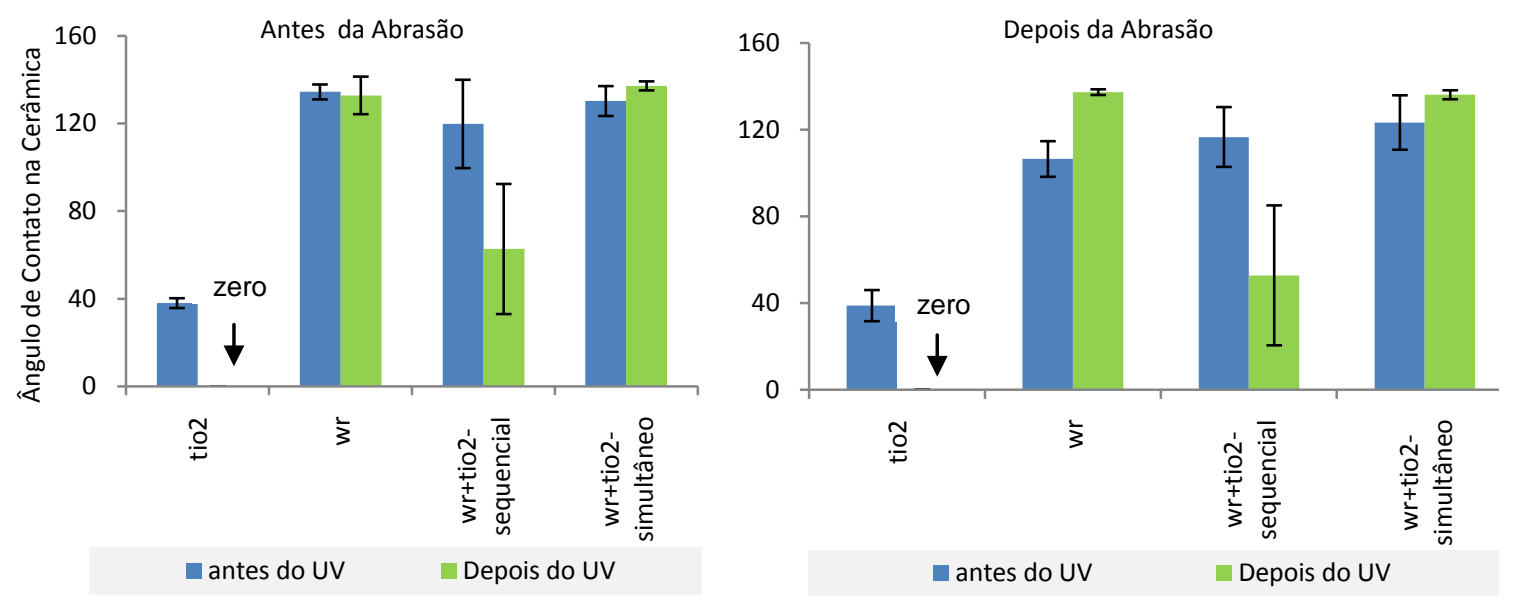

Figura 4- 15: Resultados do ângulo de contato inicial medido antes e imediatamente após a exposição à radiação ultravioleta por 4 dias, para as amostras antes e depois dos ciclos de abrasão.

Um ponto que merece destaque é que o tratamento com hidrofugante e dióxido de titânio aplicados separadamente $\left(\mathrm{WR}+\mathrm{TiO}_{2 \text {-sequencial }}\right)$ apresentou uma maior dispersão dos resultados quando comparados aos demais. Este fenômeno pode ser atribuído à falta de homogeneidade da superfície, possibilitando que apenas algumas áreas se tornem hidrofílicas. Após os ciclos de abrasão, observa-se uma leve redução dessa dispersão e as tendências ficam, ainda, mais nítidas (Figura 416). Conclusões semelhantes foram encontradas no substrato de vidro.

Na Figura 4- 21 encontram-se algumas fotos obtidas ao longo desses ensaios.
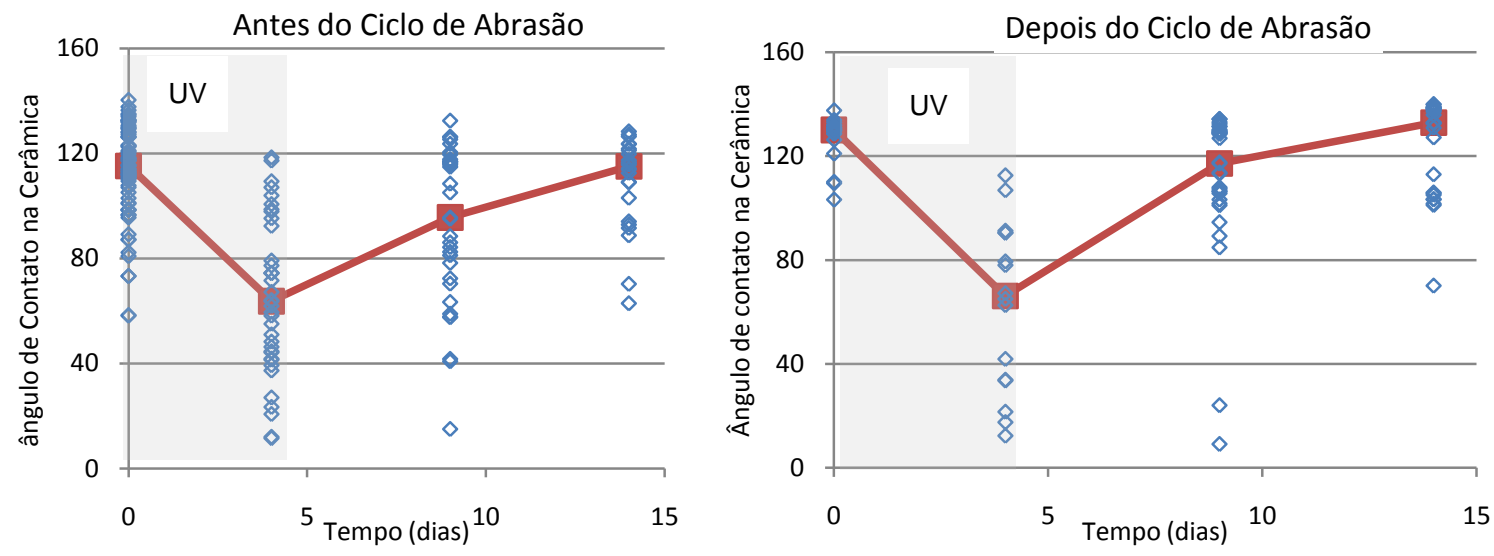

Figura 4- 16: Dispersão de resultados de ângulo de contato inicial no substrato de cerâmica ao longo dos ensaios da amostra $\mathrm{WR}+\mathrm{TiO}_{2}$-sequencial. $\mathrm{A}$ linha refere-se à mediana dos resultados. 
Além do valor inicial, a cinética de redução do ângulo de contato ao longo dos dois minutos de ensaio é outra importante fonte de informação das propriedades fotocatalíticas.

Avaliando apenas os resultados dos tratamentos com hidrofugante e a união entre o hidrofugante e o dióxido de titânio quando aplicado juntos $\left(\mathrm{WR}+\mathrm{TiO}_{2 \text {-simultâneo }}\right)$, Tabela 5 , respectivamente, constata-se que, ao longo dos dois minutos avaliados, houve pequenas alterações nos resultados e que a exposição ao UV não exerceu influência significativa.

Avaliando a aplicação do dióxido de titânio e hidrofugantes aplicados de maneira sequencial (Tabela 5) é possível constatar que a exposição à radiação ultravioleta foi responsável por uma redução muito significativa no valor mínimo do ângulo de contato. Apesar disso, persistem pontos onde o ângulo de contato inicial é alto, confirmando que a dispersão do semicondutor não é uniforme.

Além disso, constata-se que após os dois minutos de ensaio, em todas as medições realizadas as gotas se transformam em lâminas com ângulos de contato inferiores à capacidade de medição do equipamento. Esse tipo de comportamento é identificado mesmo nos locais em que o ângulo de contato inicial foi maior do que noventa graus, confirmando o elevado poder que as partículas de dióxido em transformar a superfície em hidrofílica.

Nas Figura 4- 17, Figura 4- 18 e Figura 4- 19 estão apresentados alguns resultados da cinética de redução do ângulo de contato ao longo dos dez dias de ensaios. Em todos os casos há uma contínua queda no valor do ângulo de contato medido.

Comparando as três figuras, conclui-se que quanto maior o tempo após a exposição à radiação UV maior o tempo necessário para redução do ângulo de contato a valores inferiores aos dez graus (Figura 4-20).

Os resultados obtidos imediatamente após a retirada do UV confirmam que o semicondutor encontra-se em elevado estado de excitação e com um comportamento hidrofílico de elevada intensidade, tendo sido necessário, no máximo 30 segundos para que todos os pontos atingissem ângulos de contato inferiores a dez graus (Figura 4- 17).

Dez dias após a retirada do UV, por sua vez, constata-se uma grande dispersão de resultados, com pontos ainda fotoativados e hidrofílicos e outros com comportamento hidrofóbico. Esse comportamento pode ser atribuído a um recobrimento parcial do semicondutor pelos radicais hidrofóbicos do silicone, onde apenas nos locais em que as partículas de dióxido de titânio ainda estão expostas há uma rápida redução do ângulo de contato. Nos demais a cinética é semelhante ao tratamento apenas com hidrofugante e não há redução do ângulo de contato ao longo do tempo de ensaio realizado (Figura 4- 19). Conclusão semelhante foi retirada dos resultados em substratos de vidro.

No tratamento apenas com a dispersão aquosa de dióxido de titânio a exposição à radiação ultravioleta só perdeu efeito e possibilitou a medição após 10 dias (240 horas). Isso comprova que uma parcela do semicondutor continua presente na superfície da cerâmica, mesmo após os ciclos de abrasão, que são responsáveis por conferir esse intenso comportamento hidrofílico. 
Dos dados aqui apresentados, é possível concluir que o uso do silicone como agente de ligação do dióxido de titânio aos substratos porosos e silicosos é efetivo, desde que sejam aplicados separadamente, ou seja, primeiramente o hidrofugante à base de silicone e depois o produto foto-ativado.

Quando aplicados juntos, percebe-se que a incidência de UV não provoca a fotoativação do semicondutor, o que leva a crer que as partículas de dióxido de titânio estejam recobertas pelos radicais orgânicos do hidrofugante que possuem menor tensão superficial.

De toda a bibliografia consultada, a única que faz referência a resultados sobre alteração de comportamento hidrofóbico para hidrofílico foi Irie; Hashimoto (2005), onde 1.800 horas de exposição à radiação UV, com tratamento contendo de $2,0 \%$ de dióxido de titânio, provocou uma redução no ângulo de contato de $150^{\circ}$ para $89^{\circ}$. Não há maiores descrições do experimento.

Tabela 5: Valores mínimos e máximo do ângulo de contato para os diferentes tratamentos superficiais em substratos de cerâmica após abrasão. Valores em graus.

\begin{tabular}{|c|c|c|c|c|c|}
\hline & \multicolumn{4}{|c|}{ Tempo de deposição da gota de água } \\
\hline & & \multicolumn{2}{|c|}{0 segundos } & \multicolumn{2}{|c|}{120 segundos } \\
\hline & & máximo & mínimo & máximo & mínimo \\
\hline \multirow{3}{*}{ Hidrofugante } & Antes do UV & 138,1 & 102,4 & 122,8 & 94,2 \\
\hline & Depois do UV & 140,6 & 124 & 139,9 & 122 \\
\hline & 120 horas depois do UV & 124,7 & 104,6 & 123,8 & 91,4 \\
\hline \multirow{3}{*}{$\begin{array}{l}\mathrm{wr}+\mathrm{TiO}_{2}- \\
\text { simultâneo }\end{array}$} & Antes do UV & 139,2 & 110,7 & 132,1 & 90,2 \\
\hline & Depois do UV & 141,3 & 133,9 & 138,8 & 133,3 \\
\hline & 120 horas depois do UV & 138,3 & 137,8 & 133,4 & 115,9 \\
\hline \multirow{4}{*}{$\begin{array}{l}\mathrm{wr}+\mathrm{TiO}_{2}- \\
\text { sequencial }\end{array}$} & Antes do UV & 140,4 & 88,6 & 129,6 & 24,1 \\
\hline & Depois do UV & 118,5 & 12,4 & 0 & 0 \\
\hline & 120 horas depois do UV & 134,2 & 17,8 & 128,7 & 0 \\
\hline & 240 horas depois do UV & 138,5 & 53 & 137,9 & 0 \\
\hline \multirow{4}{*}{$\mathrm{TiO}_{2}$} & Antes do UV & 45,8 & 33,6 & 0 & 0 \\
\hline & Depois do UV & 0 & 0 & 0 & 0 \\
\hline & 120 horas depois do UV & 0 & 0 & 0 & 0 \\
\hline & 240 horas depois do UV & 73,2 & 12,4 & 33,5 & 0 \\
\hline
\end{tabular}




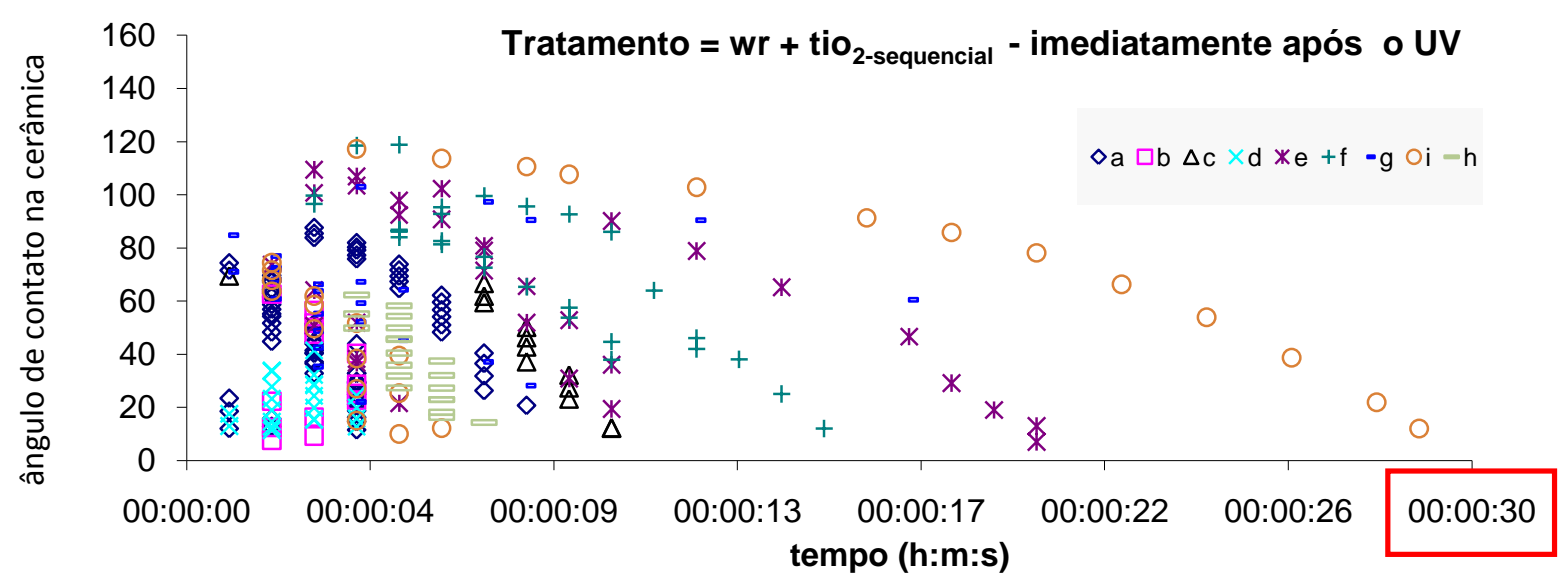

Figura 4- 17: Cinética da queda do ângulo de contato imediatamente após a exposição à radiação UV de corpo-de-prova de cerâmica tratadas com $\mathrm{WR}+\mathrm{TiO}_{2}$ sequencial.

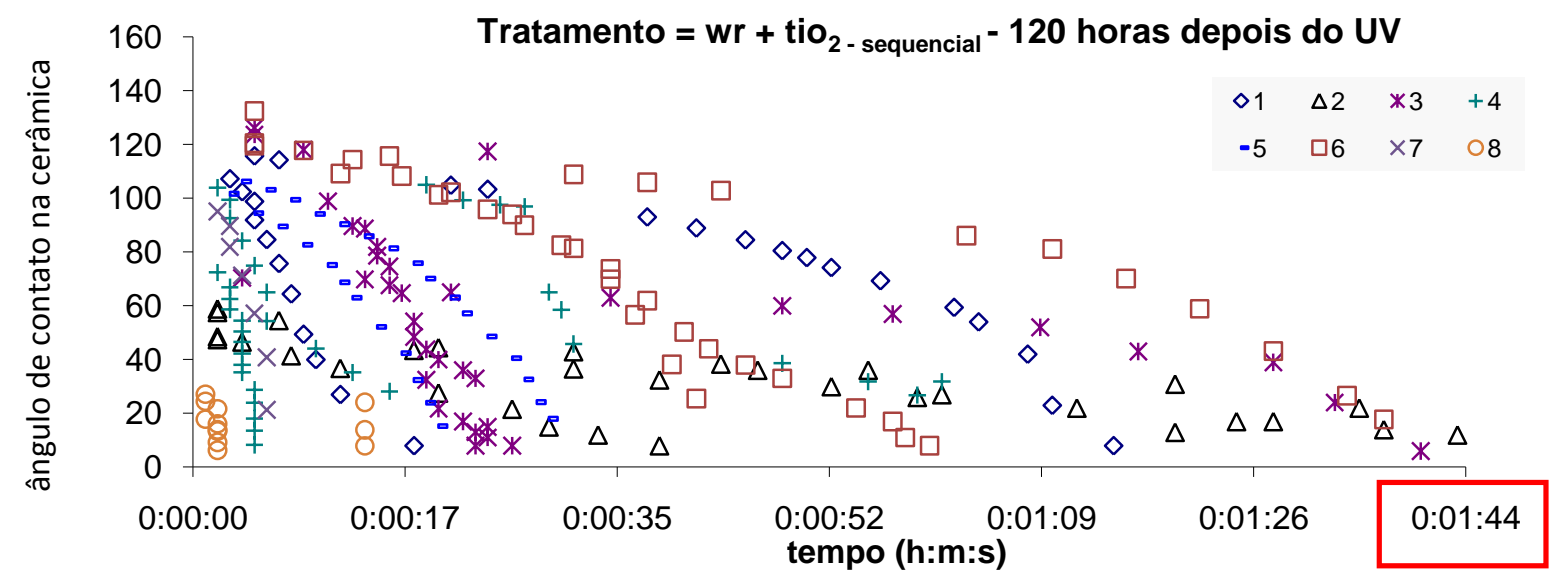

Figura 4- 18: Cinética da queda do ângulo de contato após cento e vinte horas após a exposição à radiação UV de corpo-de-prova de cerâmica tratadas com $\mathrm{WR}+\mathrm{TiO}_{2}$ - sequencial.

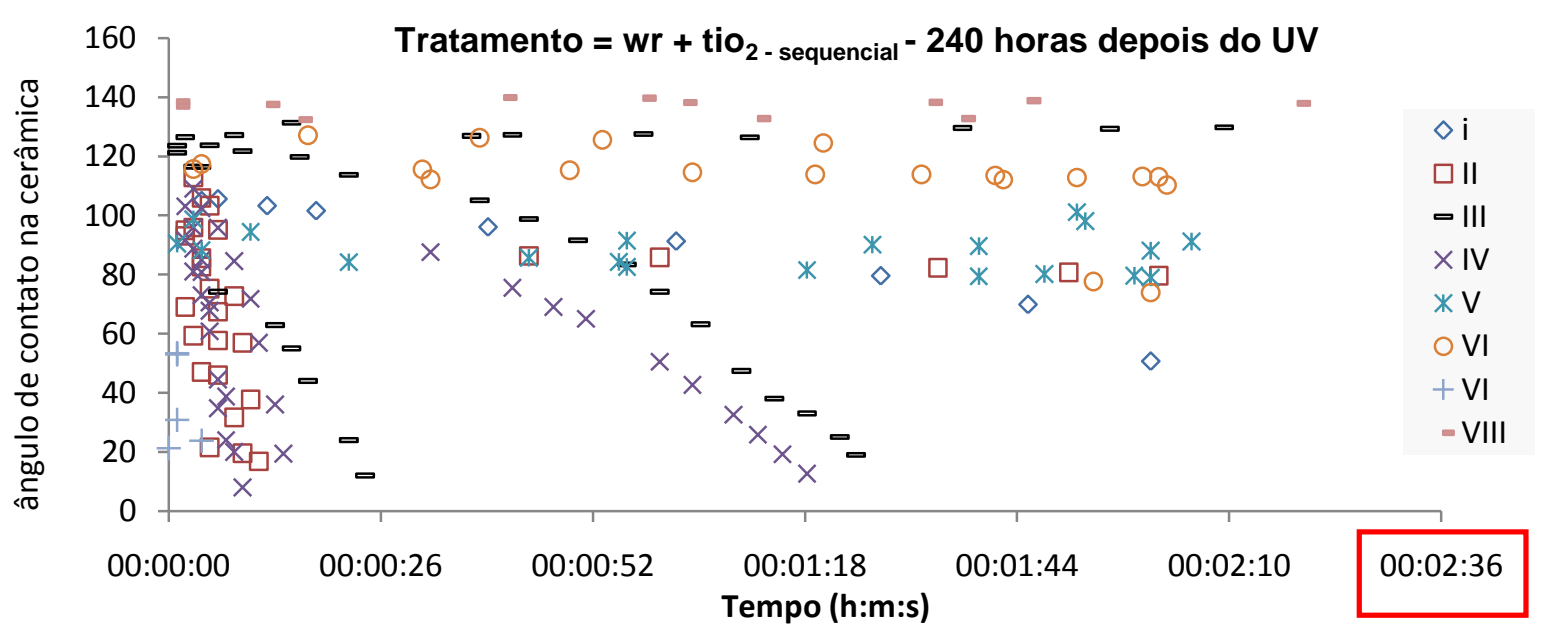

Figura 4- 19: Cinética da queda do ângulo de contato após duzentos e quarenta horas da exposição à radiação UV de corpo-de-prova de cerâmica tratadas com $\mathrm{WR}+\mathrm{TiO}_{2}$ - sequencial. 
Tempo para atingir ângulo de contato menor que $10^{\circ}$

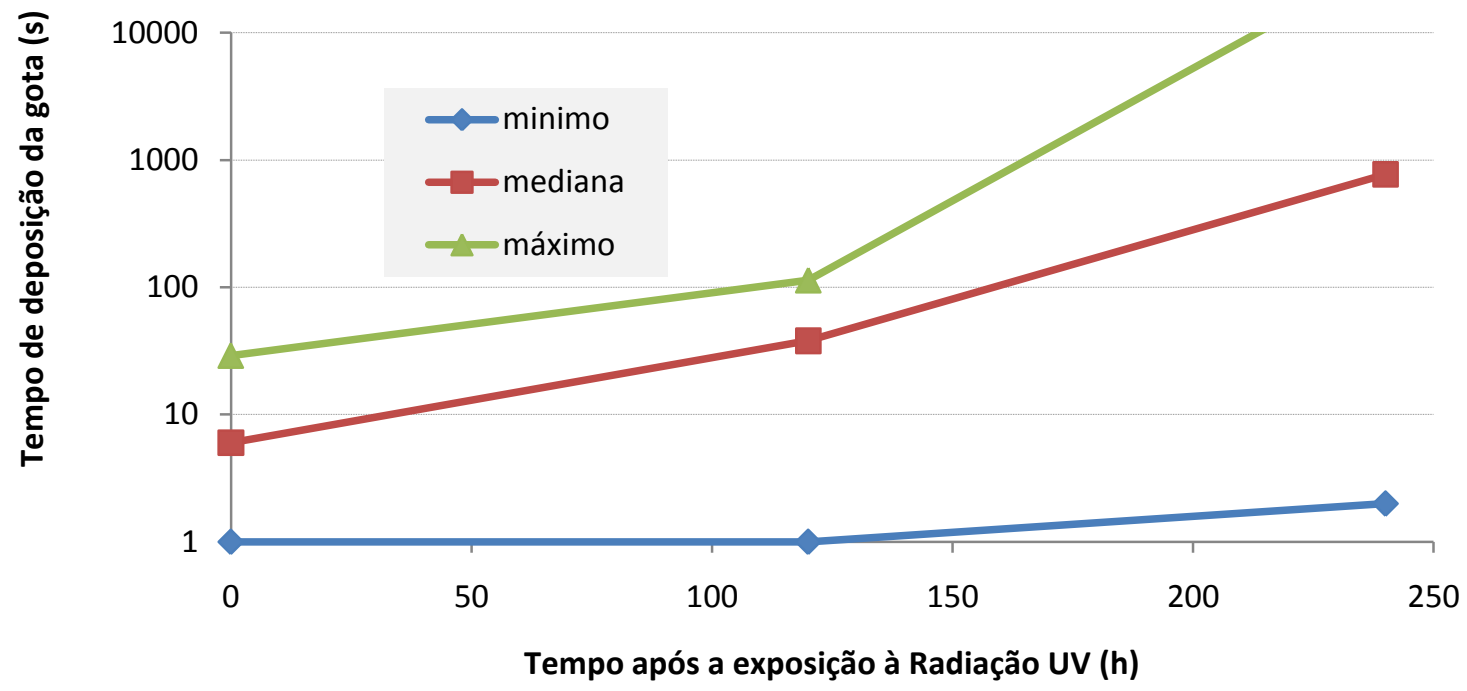

Figura 4- 20: Comparação do tempo de deposição da gota necessário para atingir valores inferiores a dez graus em substratos de cerâmica tratadas com $\mathrm{WR}+\mathrm{TiO}_{2}$ sequencial.

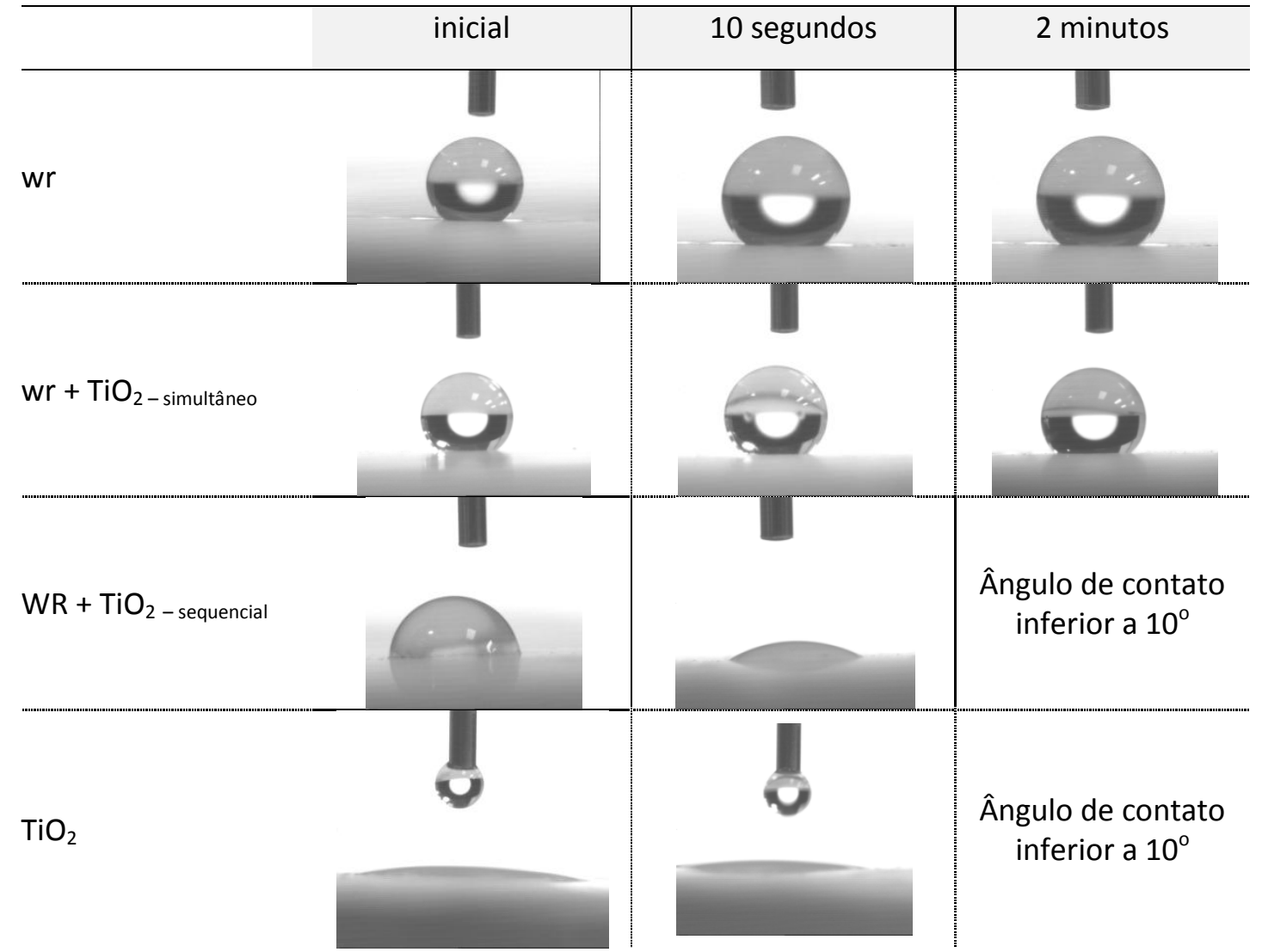

Figura 4- 21: Ilustração da variação do ângulo de contato depois da exposição à radiação UV. 


\title{
4.2.35ilicone como Agente de Ligaçã̃o do Diốxido de Titânio
}

\author{
a) FTIR
}

A união entre o dióxido de titânio e o hidrofugante à base de silicone provoca o surgimento de alterações importantes no perfil das curvas dos resultados de FTIR (Figura 4- 22).

A primeira e mais importante alteração está no surgimento de pequenos picos na faixa dos $920 \mathrm{~cm}^{-1}$ a $950 \mathrm{~cm}^{-1}$ que referem-se às ligações Ti-O-Si (Cheng et. al., 2003; Guan, 2003; Sayilkan et. al., 2007 e Prasad et. al., sd). Além disso, percebe-se uma grande intensidade de pico na faixa dos $910 \mathrm{~cm}^{-1}$ correspondente a radicais hidroxilas ligados ao titânio e ao silício (Prasad et. al., sd).

A fraca intensidade dos picos correspondente à ligação entre o silício e o titânio já foi previamente destacada, sendo que, para Cheng et. al.(2003), a presença de um pico na faixa dos $920 \mathrm{~cm}^{-1}$ é uma prova inequívoca do surgimento dessas ligações.

Além dessa alteração, outras importantes podem ser identificadas: (i) o surgimento de um pico na faixa dos $1450 \mathrm{~cm}^{-1}$; (ii) o surgimento de um pico na faixa dos 1040 $\mathrm{cm}^{-1}$; e (iii) uma redução da vibração na faixa dos $1260 \mathrm{~cm}^{-1}$ e $3600-4000 \mathrm{~cm}^{-1}$.

A primeira pode ser atribuída à vibração do radical hidrofóbico do hidrofugante (Prasad et. al., sd); a segunda pode ser atribuída ao surgimento da matriz Si-O-Si que é resultado do processo de poli-condensação dos hidrofugantes à base de silicone (Chu et. al., 2009), conforme apresentado no Capítulo 2; e a terceira é atribuída à volatização da água que estava quimicamente ligada durante a polimerização do silicone. Lembra-se que a temperatura utilizada para a secagem das amostras foi de $60^{\circ} \mathrm{C}$.

Um ponto que merece ser destacado é que os resultados apresentaram boa repetibilidade (Figura 4- 23). 


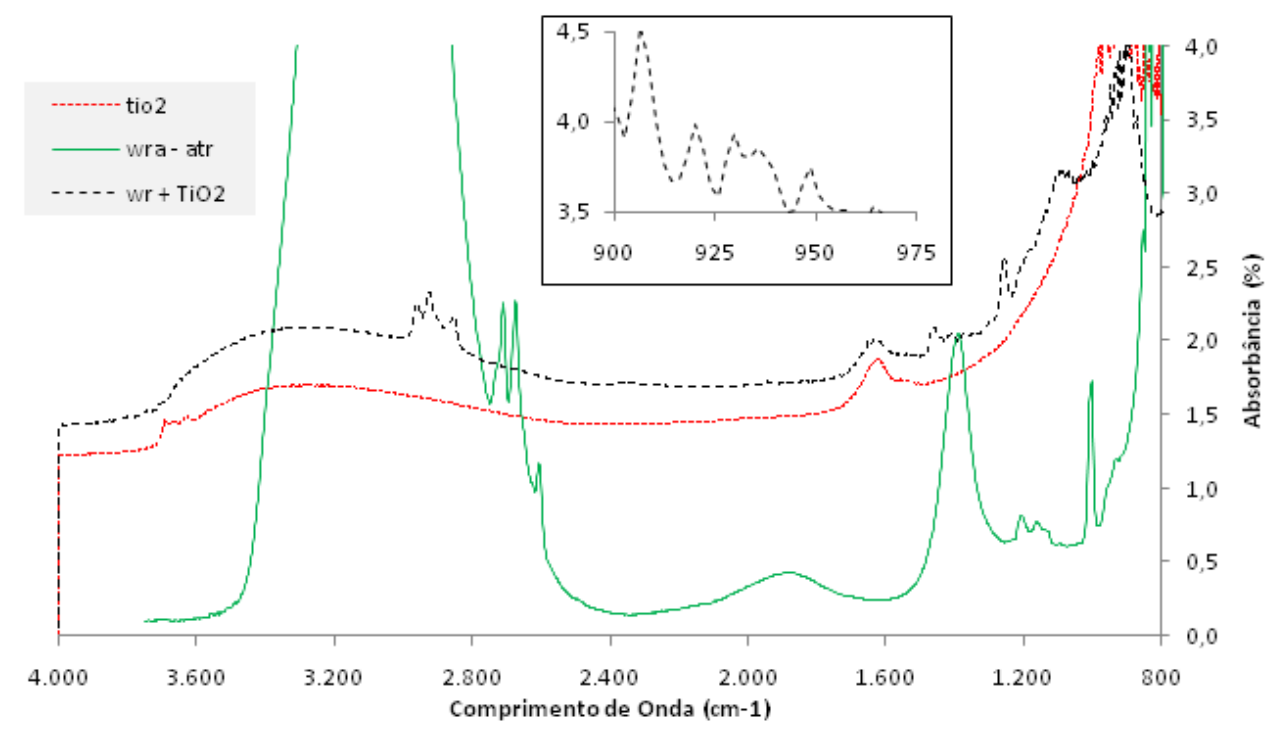

Figura 4- 22: Resultados do FTIR mostrando a ligação entre o dióxido de titânio e o hidrofugante.

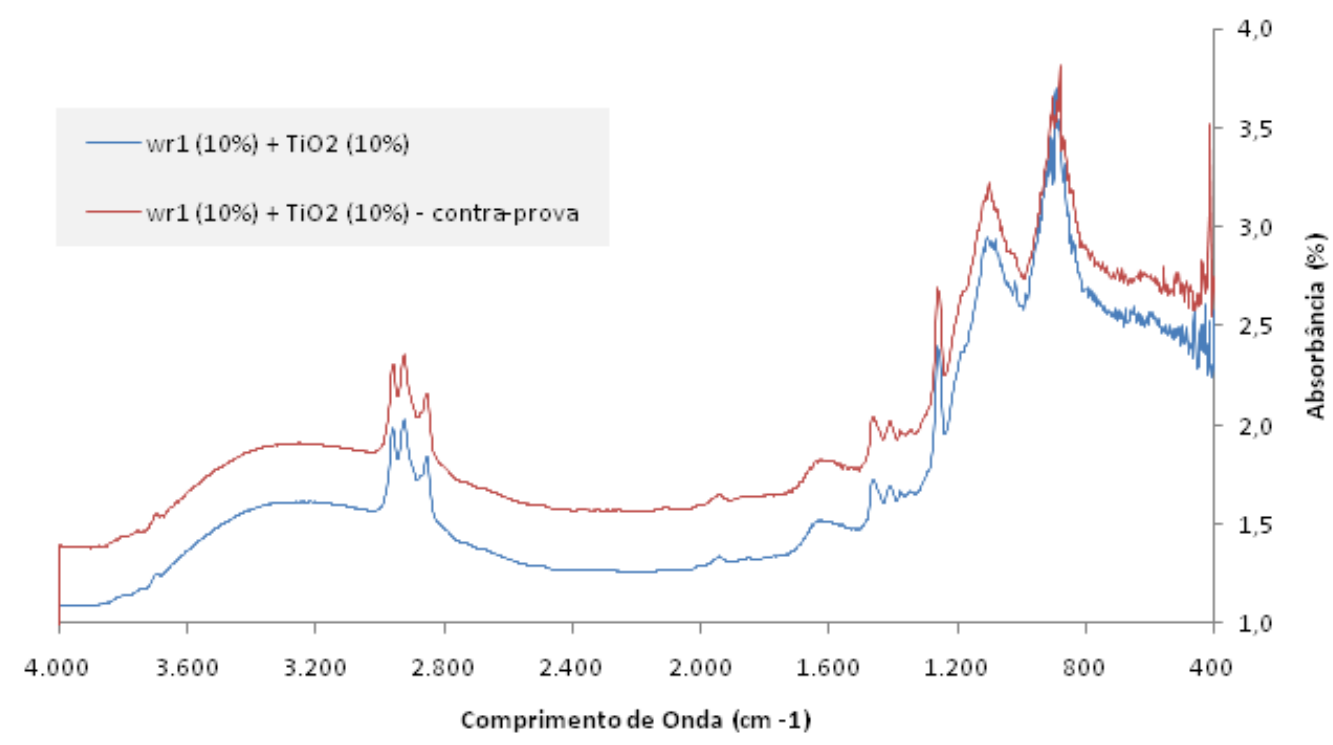

Figura 4- 23: Repetibilidade dos resultados para dois corpos-de-prova da amostras de $\mathrm{Wr}+\mathrm{TiO}_{2 \text {-sequencial. }}$

Além desses pontos, uma importante alteração no perfil das curvas é identificada em três picos na faixa dos $2850 \mathrm{~cm}^{-1}, 2930 \mathrm{~cm}^{-1}$ e $2960 \mathrm{~cm}^{-1}$ (Figura 4- 24). Segundo Coronado et. al. (2001), esses picos podem ser atribuídos a ligações dos radicais orgânicos, porém é de se destacar que quanto maior é o teor de dióxido de titânio na suspensão mais evidentes e intensos ficam os picos.

Uma possibilidade para explicar tal comportamento é que o surgimento das ligações Ti-O-Si pode ter causado uma perturbação no hidrofugante, fazendo com que haja 
um descolamento dos três picos originalmente identificados nas faixas $2600 \mathrm{~cm}^{-1}$, $2670 \mathrm{~cm}^{-1}$ e $2700 \mathrm{~cm}^{-1}$ (Figura 4- 22).

Acrescenta-se ainda que a presença de pequenos picos na amostra de $\mathrm{TiO}_{2}$ indica que o produto P25 já possui um recobrimento com partículas de sílica. Esse processo é bem conhecido na área de pigmentos brancos, e tem a função de reduzir a aglomeração das partículas quando em forma de pó (Tan, 2004).

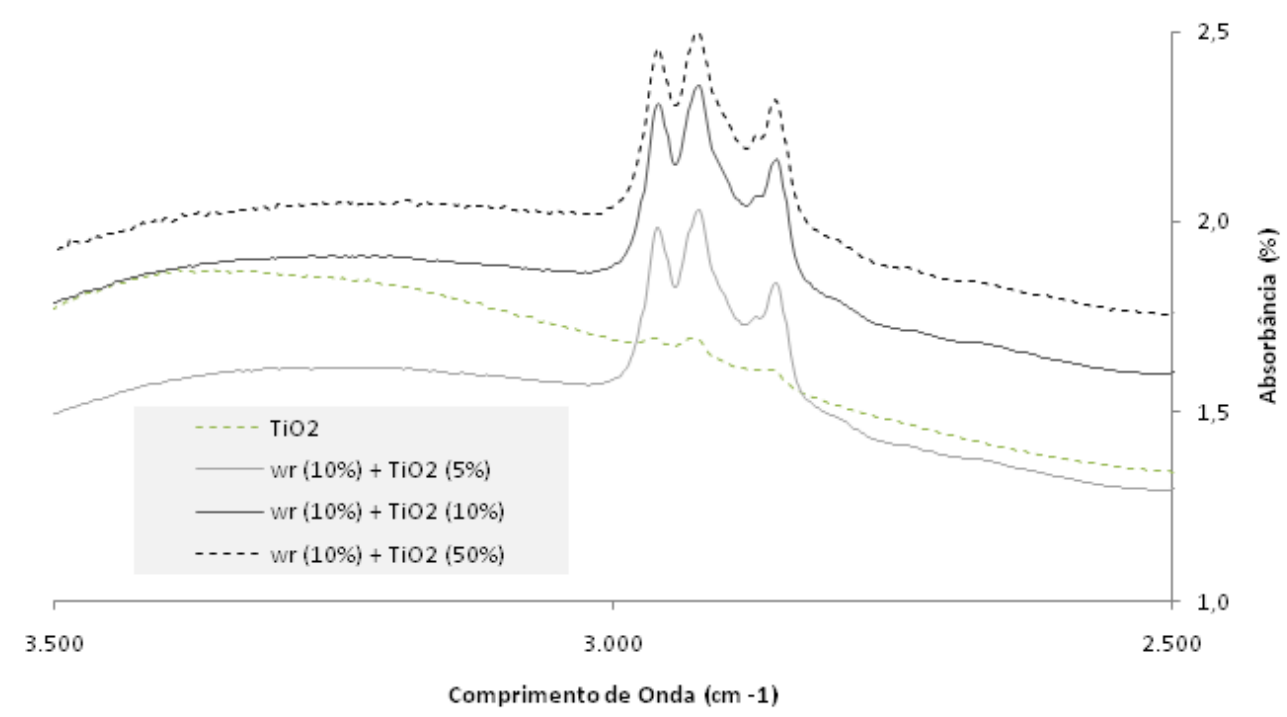

Figura 4- 24: Influência do teor de dióxido de titânio nos resultados de FTIR.

b) MEV

Na Figura 4- 25 estão apresentados os resultados do MEV para a referência. Percebe-se que a presença de titânio é muito pequena em todos os cinco pontos medidos na microssonda e que o substrato é formado, basicamente, por cálcio, silício, oxigênio e carbono. Esse resultado é de se esperar uma vez que as análises foram realizadas sobre placas de fibrocimento. 


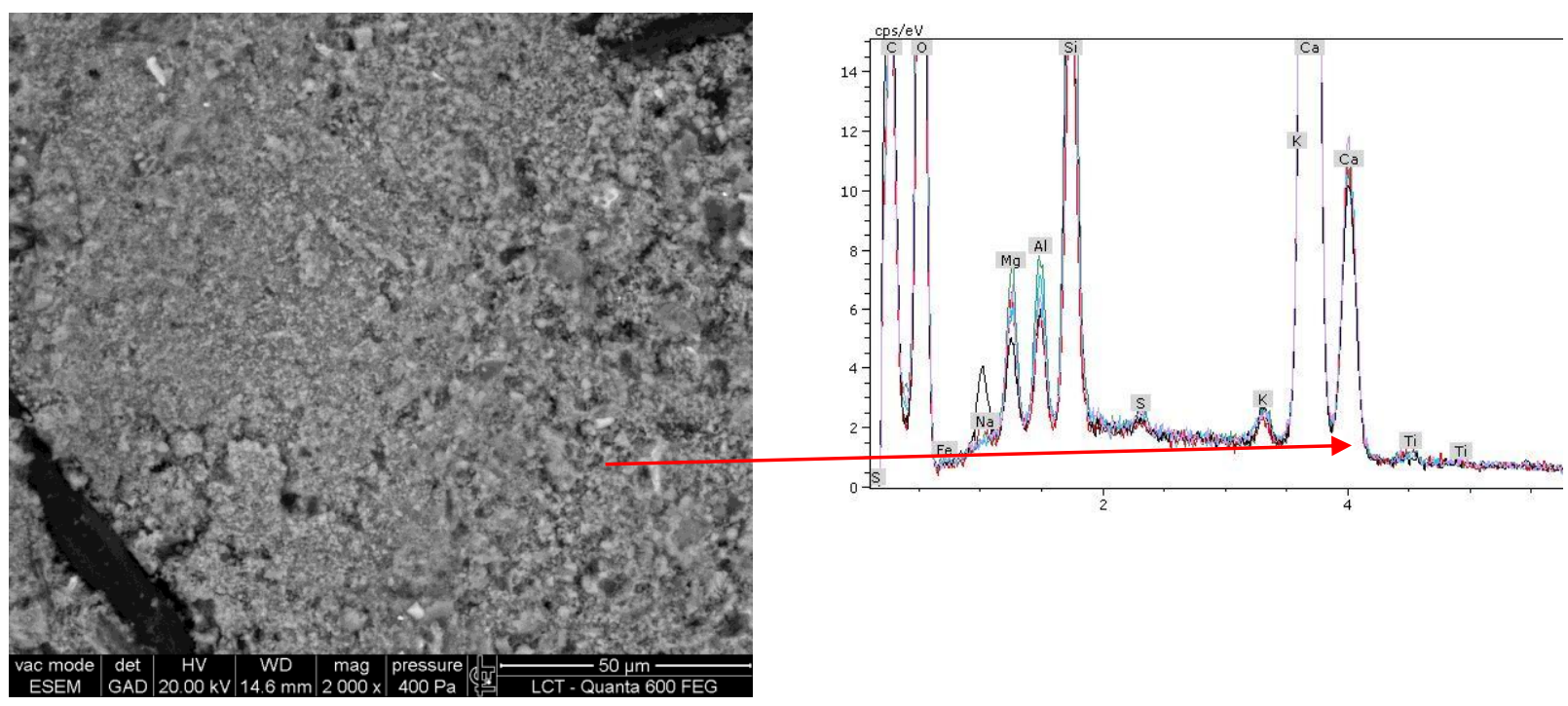

Figura 4- 25: Resultado da Microscopia Eletrônica de Varredura sobre a amostra de referência. Notar pequena presença do titânio.

Nas amostras que foram submetidas a tratamentos superficiais com suspensão aquosa de dióxido de titânio, percebe-se um contínuo aumento dos picos de titânio à medida que se aumenta a concentração do semicondutor na suspensão (Figura 426 e Figura 4- 27).

Ocorre, porém, que os resultados apresentam uma elevada variabilidade na intensidade dos picos de titânio em um mesmo corpo-de-prova. Isso pode ser atribuído a uma inadequada dispersão do semicondutor na superfície do substrato, fazendo com que sejam percebidas regiões com grandes diferenças de brilho e coloração. Nas mais claras, há maior intensidade de pico de titânio (Figura 4- 28).

Apesar disso, é possível afirmar que, anteriormente aos procedimentos de abrasão, a intensidade de pico titânio está diretamente relacionada com a concentração de $\mathrm{TiO}_{2}$ utilizada nas suspensões (Figura 4- 29).

Por outro lado, quando se usa o hidrofugante à base de silicone como agente de ligação constata-se um comportamento diferente, para todas as concentrações avaliadas (Figura 4- 30 e Figura 4- 31). Nesse caso há uma importante redução na intensidade de pico média do titânio, medido no EDS, que pode ser atribuído a um recobrimento das partículas do semicondutor pelos produtos à base de silicone, que impedem sua detecção pela microssonda (Figura 4- 29 e Tabela 6). 


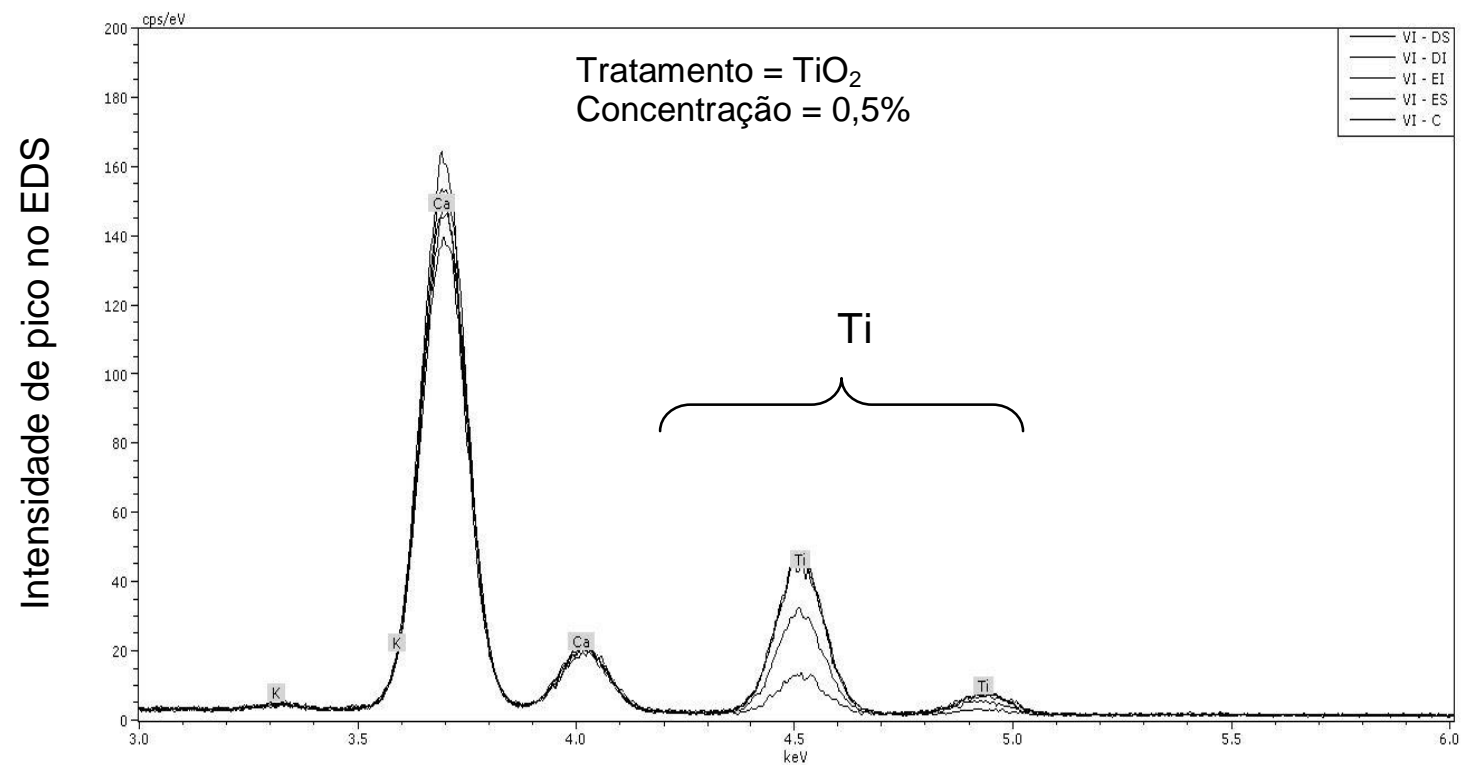

Figura 4- 26: Espectros dos cinco pontos obtidos no EDS da amostra tratadas com suspensão aquosa de dióxido de titânio com concentração de 2,00\% de $\mathrm{TiO}_{2}$ antes da abrasão.

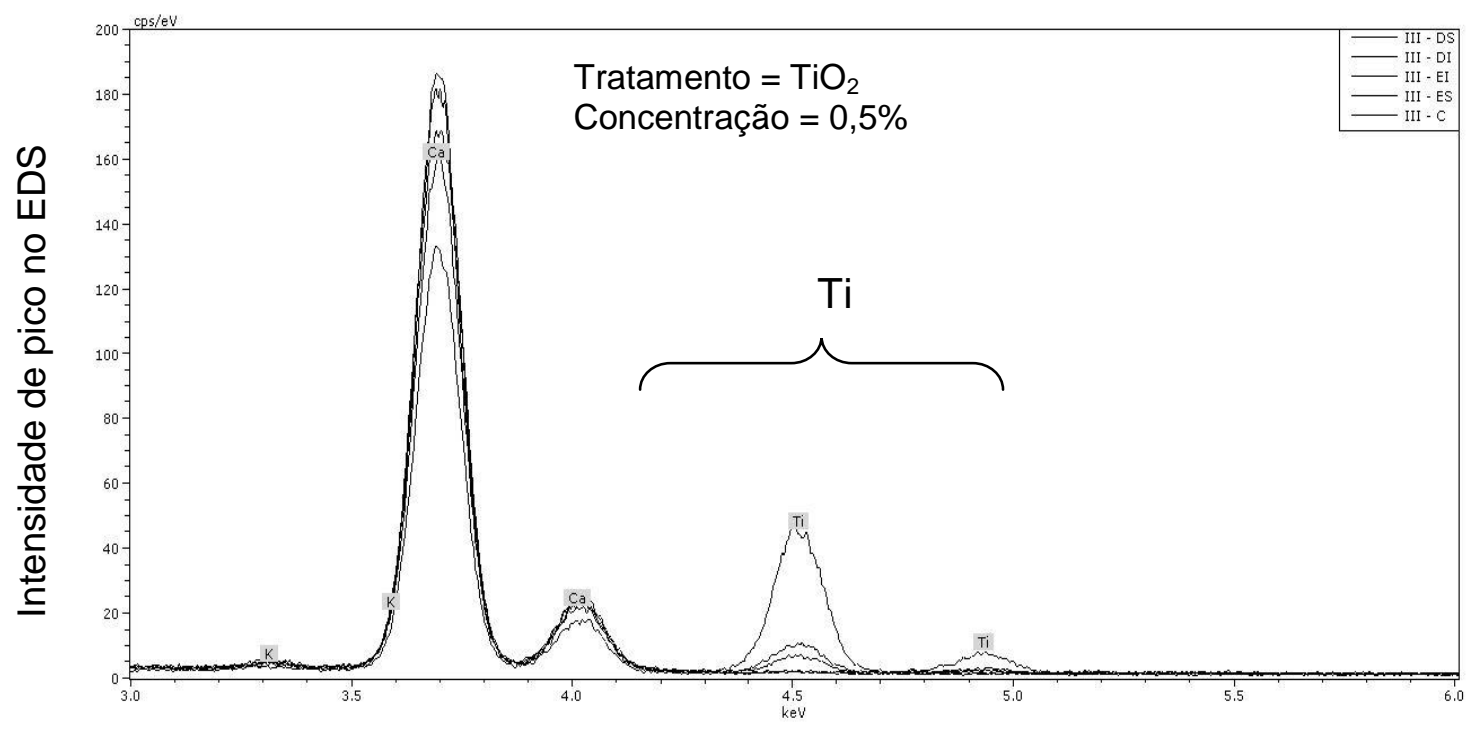

Figura 4- 27: Espectros dos cinco pontos obtidos no EDS da amostra tratadas com suspensão aquosa de dióxido de titânio com concentração de 0,50\% de $\mathrm{TiO}_{2}$ antes da abrasão. 


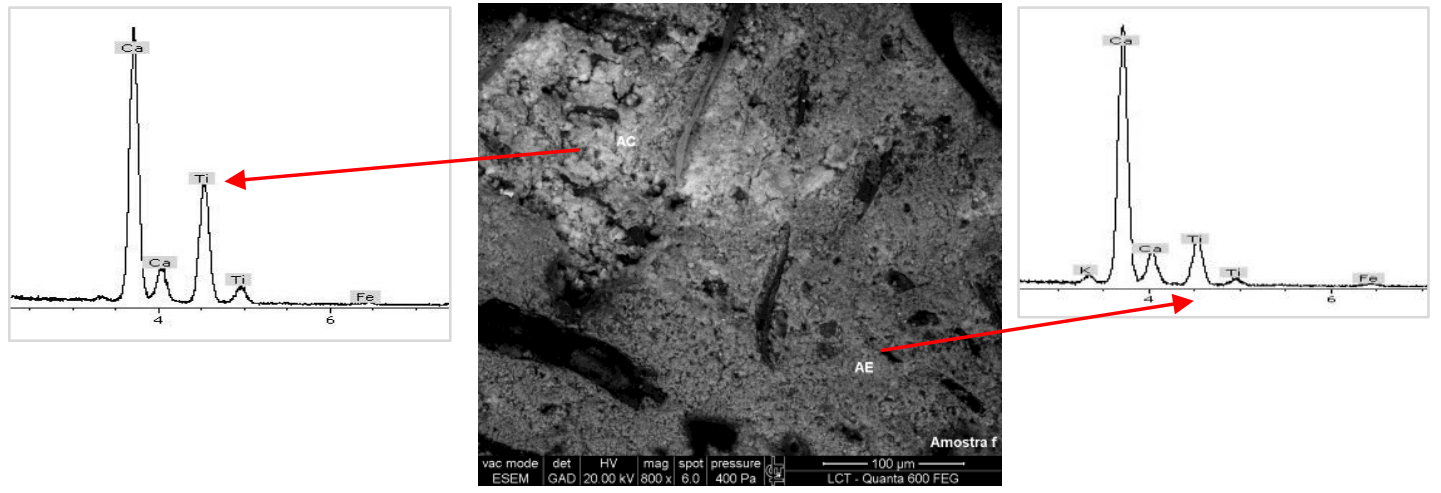

Figura 4- 28: Diferença entre a intensidade de picos referente ao titânio no EDS em áreas claras e escuras de um mesmo corpo-de-prova. Aumento de 800X.
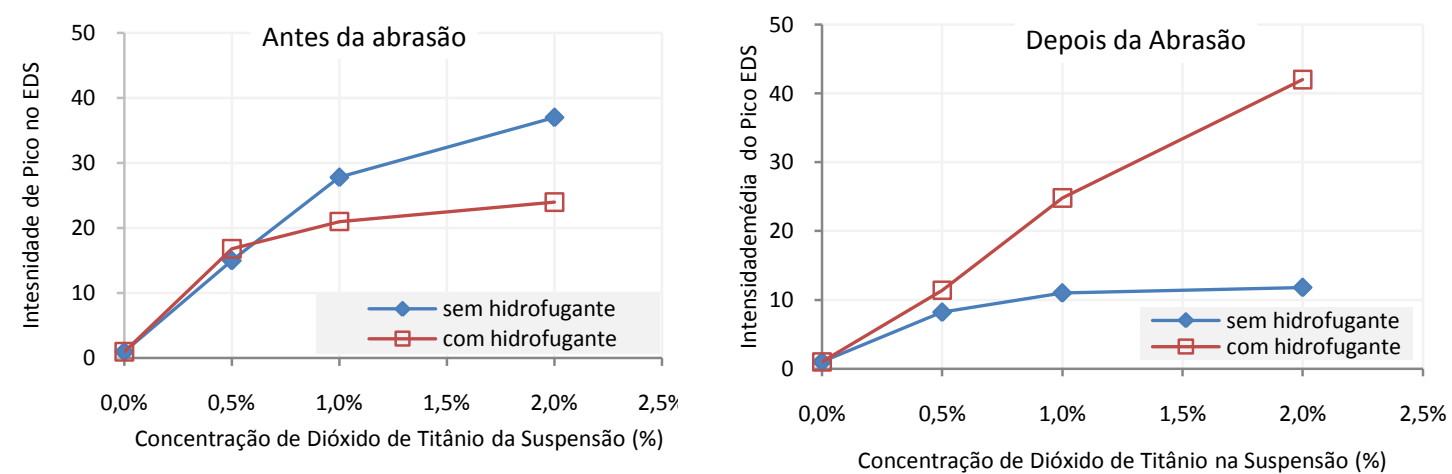

Figura 4- 29: Influência do teor de dióxido de titânio na intensidade de pico média do titânio no EDS. Cada ponto refere-se a cinco medições.

Tabela 6: resultados da intensidade de pico de titânio medido pela microssonda.

\begin{tabular}{|r|l|l|c|c|c|c|}
\hline $\begin{array}{r}\text { Concentração } \\
\text { de } \mathrm{TiO}_{2}\end{array}$ & Abrasão & $\begin{array}{l}\text { Uso de } \\
\text { hidrofugante }\end{array}$ & media & mediana & máximo & mínimo \\
\hline $0 \%$ & não & não & 1 & 1 & 1 & 1 \\
\hline $0 \%$ & $\operatorname{sim}$ & $\operatorname{sim}$ & 1 & 1 & 1 & 1 \\
\hline $0,50 \%$ & não & não & 15 & 10 & 50 & 1 \\
\hline $0,50 \%$ & $\operatorname{sim}$ & $\operatorname{sim}$ & 17 & 10 & 17 & 1 \\
\hline $0,50 \%$ & não & não & 11 & 10 & 20 & 6 \\
\hline $0,50 \%$ & $\operatorname{sim}$ & $\operatorname{sim}$ & 28 & 27 & 42 & 15 \\
\hline $1,00 \%$ & não & não & 11 & 12 & 20 & 3 \\
\hline $1,00 \%$ & $\operatorname{sim}$ & $\operatorname{sim}$ & 21 & 25 & 45 & 1 \\
\hline $1,00 \%$ & não & não & 25 & 16 & 48 & 12 \\
\hline $1,00 \%$ & $\operatorname{sim}$ & $\operatorname{sim}$ & 37 & 43 & 47 & 15 \\
\hline $2,00 \%$ & não & não & 12 & 10 & 20 & 5 \\
\hline $2,00 \%$ & sim & sim & 24 & 15 & 60 & 10 \\
\hline $2,00 \%$ & não & não & 42 & 35 & 65 & 25 \\
\hline $2,00 \%$ & sim & sim & & & 7 \\
\hline
\end{tabular}




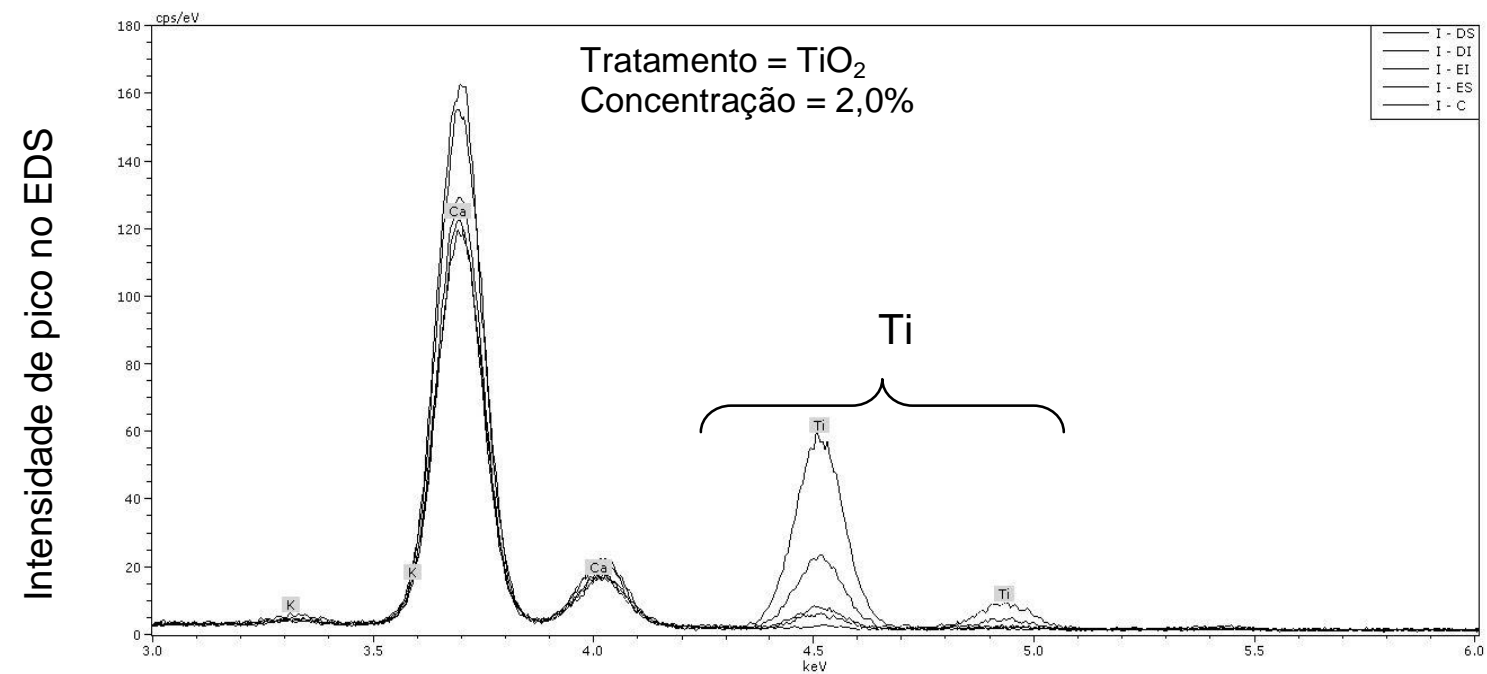

Figura 4- 30: Espectros dos cinco pontos obtidos no EDS da amostra tratadas com hidrofugante à base de silicone e dióxido de tit6Anio aplicados de maneira sequencial com concentração de $2,0 \%$ de $\mathrm{TiO}_{2}$ antes da abrasão.

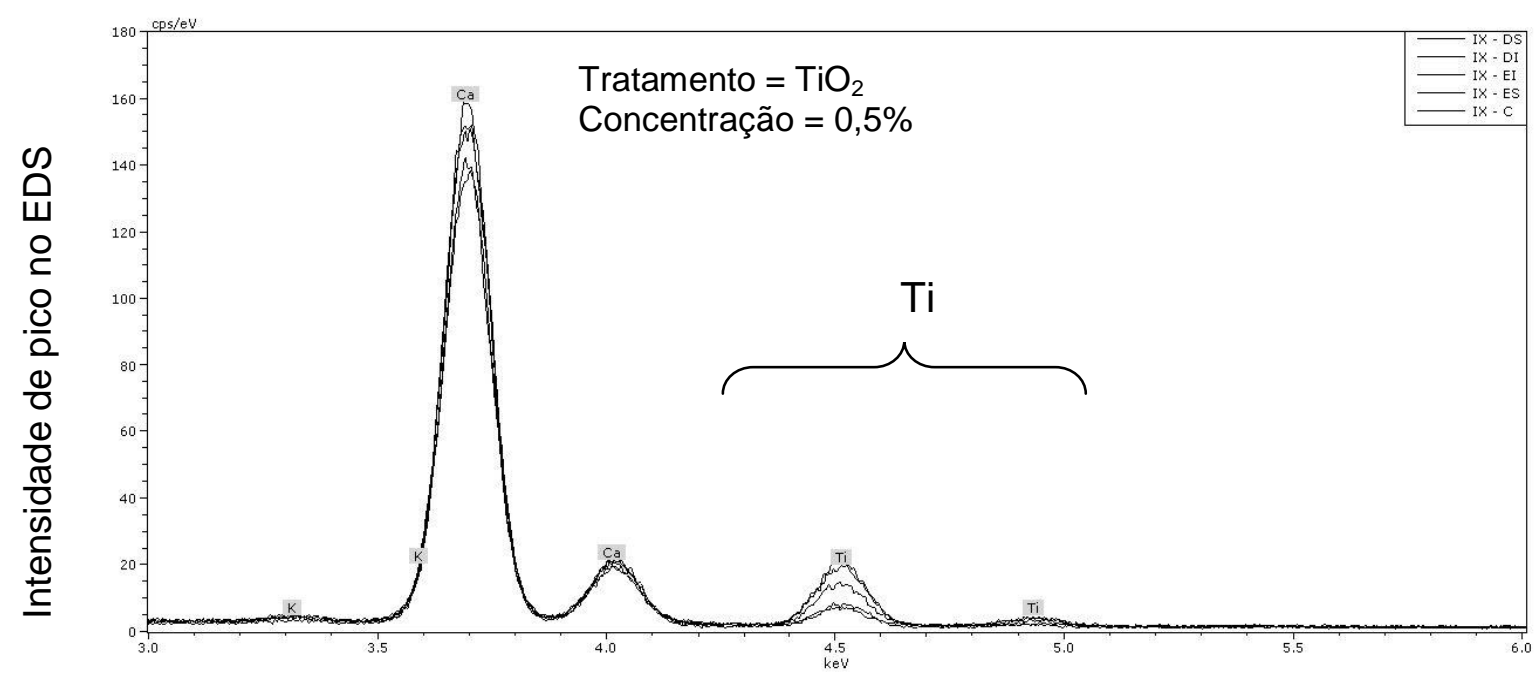

Figura 4- 31: Espectros dos cinco pontos obtidos no EDS da amostra tratadas com suspensão aquosa de dióxido de titânio com concentração de $0,5 \%$ de $\mathrm{TiO}_{2}$ antes da abrasão.

Após a abrasão, a ação do hidrofugante como agente de ligação fica mais evidente (Figura 4- 29). Aqui a intensidade média dos picos foi consideravelmente superior às medidas nas amostras sem silicone, como consequencia direta do aumento da resistência à abrasão provocada pela ligação química Si-O-Ti identificada no FTIR.

Quando comparado com os resultados antes da abrasão consta-se que onde houve a união do $\mathrm{TiO}_{2}$ e o hidrofugante há um contínuo aumento na intensidade média dos picos como consequência de uma maior homogeneização da superfície, da lixiviação de partículas pouco aderidas e de uma maior exposição do semi-condutor. As micrografias na Figura 4- 32 ilustram bem essas mudanças na textura superficial dos corpos-de-prova antes 
e depois da abrasão.

Contudo, quando o hidrofugante não foi utilizado, observam-se reduções de $45 \%$ e $70 \%$ na intensidade de pico do titânio, para as concentrações de $0,5 \%$ e $2,0 \%$, respectivamente, quando comparados com os valores anteriores à abrasão. Nesse caso, o valor final mostrou-se pouco dependente da concentração de $\mathrm{TiO}_{2}$ utilizado na suspensão para o tratamento.

Desta forma, é possível concluir que os cem ciclos de abrasão executados forma insuficientes para retirar todo a dióxido de titânio depositado na superfícies dos corpos-de-prova, e que a quantidade restante é suficiente para conferir atividade fotocatalítica quando incididos por radiação ultravioleta.

Mas quando se usa o hidrofugante à base de silicone como agente de ligação, há um nítido aumento da resistência à abrasão das tintas, fazendo com que uma maior quantidade de partículas do semicondutor permaneça na superfície após os ciclos de abrasão.

Por último, as avaliações microscópicas confirmam que o tamanho de partícula do semicondutor utilizado é consideravelmente inferior à identificada na etapa de caracterização usando o granulômetro a laser (no item 4.1.1). Os resultados confirmam que as partículas possuem dimensões nanométricas (em torno de $30 \mathrm{~nm})$, mas que se encontram aglomeradas na superfície do fibrocimento (Figura 4- 33). Portanto, é necessário aprimorar o processo de dispersão das partículas de dióxido de titânio para uma maior otimização deste método.

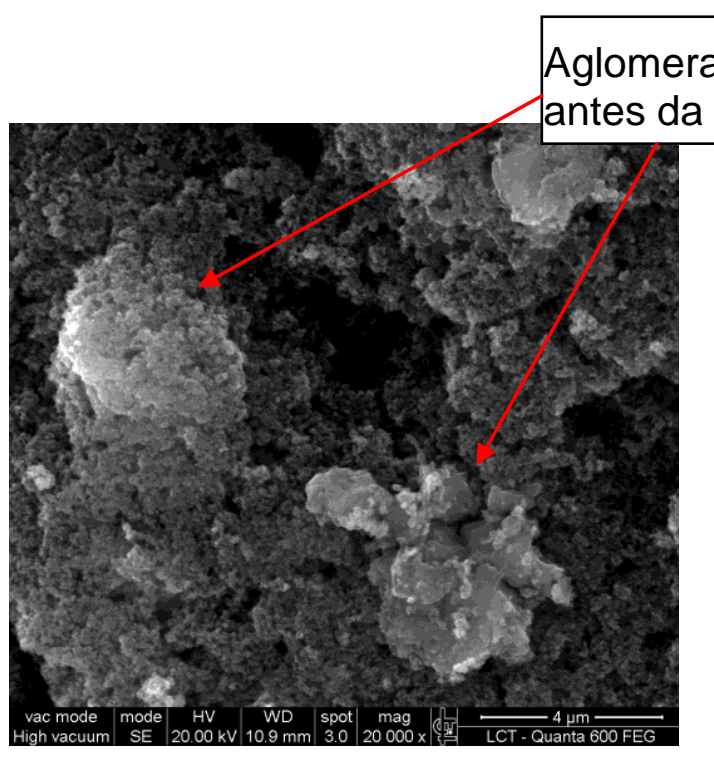

(a)

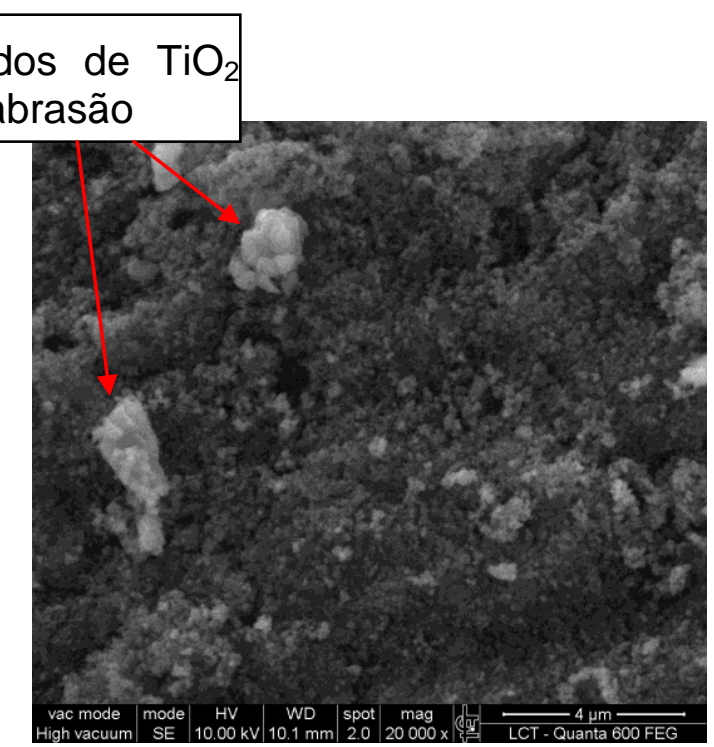

(b)

Figura 4- 32: Superfície de amostras com 2,0\% de dióxido de titânio sem agente de ligação antes (a) e depois da abrasão (b). Notar a menor presença de aglomerados na superfície do substrato após abrasão. Aumento de 20.000X 


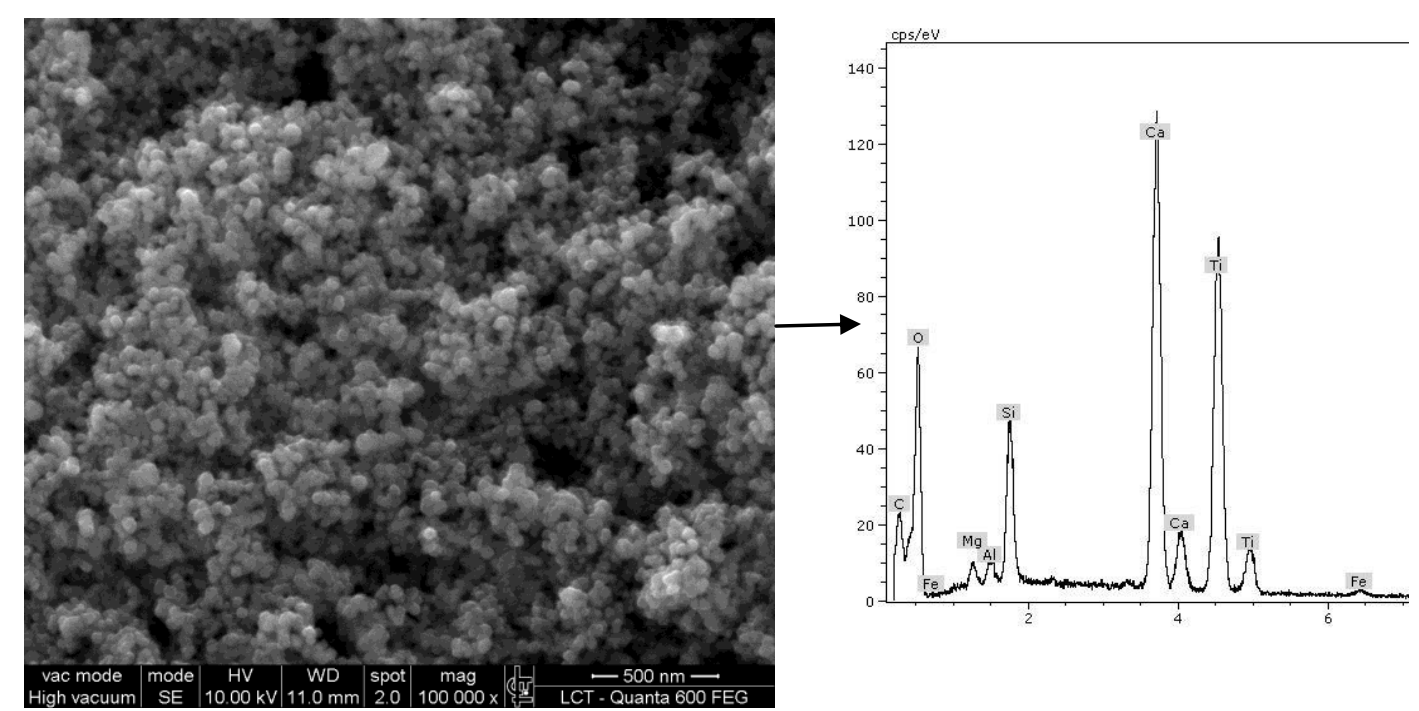

Figura 4- 33: Ilustração de um aglomerado de $\mathrm{TiO}_{2}$ depositado na superfície de um corpo-de-prova. Aumento de 100.000X

\subsection{Conclusốes do Capítulo}

Para se obter uma superfície com propriedades fotocatalíticas nos materiais de construção porosos e silicosos, utilizando-se do dióxido de titânio é necessário empregar um promotor de adesão.

Os resultados aqui apresentados comprovam que os hidrofugantes à base de silicone se mostram eficientes agentes de ligação, por possibilitarem a formação de ligações químicas ao substrato e ao semicondutor, capazes de suportar ciclos de abrasão. Isso porque os $\mathrm{Si}(\mathrm{OH})$ liberados durante o seu processo de hidrólise e policondensação conseguem reagir com a superfície hidrolisada do dióxido de titânio, formando as ligações $\mathrm{Si}-\mathrm{O}-\mathrm{Ti}$ e com o substrato. Esses resultados comprovam a hipótese experimental estabelecida para esta etapa da pesquisa.

Ocorre, porém, que para permitir a fotoativação pela exposição à radiação UV, fazse necessário que o hidrofugante e o semicondutor sejam aplicados em momentos diferentes (aqui, foi testada de maneira sequencial, com defasagem de um minuto). Primeiramente o hidrofugante e sobre ele a suspensão de dióxido de titânio. Caso contrário, os radicais hidrofóbicos do hidrofugante, que têm menor tensão superficial, recobrem a superfície do dióxido de titânio e criam uma barreia ao UV que impedem os efeitos fotocatalíticos.

A aplicação de forma sequencial faz com que as superfícies, quando incididas por radiação ultravioleta, tornem-se hidrofílicas caracterizadas por ângulos de contato próximos a zero. Este fenômeno é benéfico para a criação de superfícies autolimpantes, pois, a lâmina de água criada auxilia no processo de arraste das partículas aderidas (Figura 4- 34).

Os resultados comprovaram, também, que o teor máximo de dióxido de titânio, com o método de dispersão e os aglomerados de dimensão micrométrica utilizados, que pode ser aplicada sem que provoque alterações nas propriedades estéticas do 
substrato é de 1,0\%. Este teor mostrou-se adequado para provocar atividade fotocatalítica, que aqui foi caracterizada pela redução do ângulo de contato inicial e por uma aceleração na sua cinética.

Por último, é possível concluir que a metodologia aqui utilizada mostrou-se efetiva para se alcançar as conclusões aqui destacadas, com a confiabilidade necessária para uma tese de doutorado.

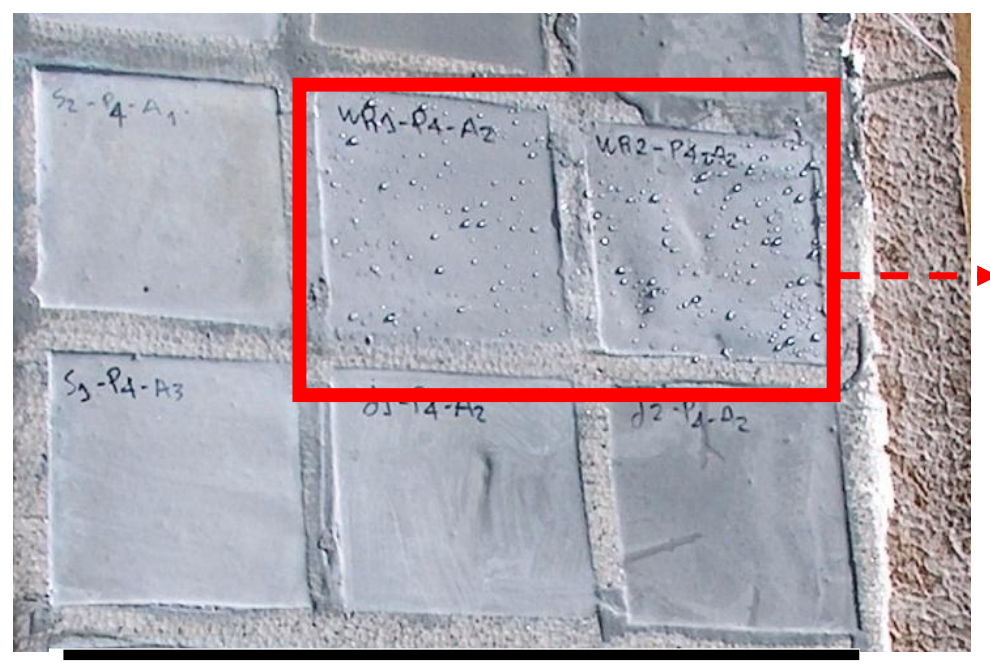

Nos locais onde houve tratamento apenas com hidrofugante, a chuva se deposita na forma de gotas, como consequencia do elevado ângulo de contato formado.

Nos locais onde houve a união entre o hidrofugante e o dióxido de titânio a água se espalha na forma de lâmina, como consequência do baixo ângulo de contato, não deixando resíduos.

$60 \mathrm{~cm}$

Figura 4- 34: Comparação entre a forma de deposição da chuva e a superfície de corpos-de-prova de argamassa expostos em estação de envelhecimento natural na cidade de São Paulo. Fonte: Arquivo pessoal do autor. 


\section{CAPÍTULO V}

\section{Avaliação da Eficiência do} Método Proposto na Prevenção de Manchas

\section{Introduçăo}

O tratamento superficial dos materiais de construção com semicondutores fotoativado contribui, potencialmente, para a criação de superfícies autolimpantes, uma vez que conseguem oxidar às partículas de poluição que encontrem-se aderidas à sua superfície e porque sua elevada hidrofilia facilita arraste dessas partículas.

Ocorre, porém, que, como comentado no capítulo 3, essa redução do ângulo de contato aumenta as forças capilares e, pode vir a facilitar o desenvolvimento de microorganismos, quando em condições de serviço. Trabalho como os de Kurth (2008) e Chen et. al (2009), identificaram crescimento de microorganismoe em argamassa e madeira tratadas $c 0 m \mathrm{TiO}_{2}$, respectivamente, com base em ensaios em escala laboratorial.

Além disso, a união do hidrofugante e do dióxido de titânio aplicadas de maneira sequencial, conforme desenvolvido no capítulo, procura evolui neste sentido, uma vez que confere propriedades hidrofóbicas aos materiais de construção, mas que sob ação do UV comportam-se como hidrofílicos, com ângulo de contato muito baixo.

Essa configuração é, potencialmente, mais benéfica para as vedações externas dos edifícios pois se beneficia tanto da hidrofobia quanto dos processos fotocatalíticos, com conseqüentes reduções da deposição de partículas de poluição quanto da minimização do crescimento de microrganismos. Desta forma, o objetivo desse capítulo é investigar essa hipótese.

\subsection{Objetivo}

O objetivo deste capítulo é avaliar eficiência do tratamento superficial com hidrofugantes e partículas fotoativadas aplicado de maneira sequencial, conforme 
proposto no Capítulo 4, na inibição do surgimento de manchas dos materiais de construção silicosos e porosos destinados às vedações externas de edificações.

Além disso, busca avaliar as consequências do tratamento proposto na cinética de absorção d'água, uma vez que a redução do ângulo de contato causada pelos processos fotocatalíticos pode aumentar as forças capilares e, consequentemente, 0 teor de umidade dos materiais tratados.

\subsection{Planejamento Experimental}

A Figura 5- 1 apresenta o planejamento experimental utilizado para o desenvolvimento deste capítulo. Todo ele foi desenvolvido em escala laboratorial, sendo que as avaliações foram feitas de maneira comparativa entre amostras com diferentes tratamentos superficiais:

- sem tratamento superficial: referência;

- dióxido de titânio $\left(\mathrm{TiO}_{2}\right)$ : suspensão aquosa de dióxido de titânio, com uma concentração de $1,0 \%$ em relação à massa de água. Esse teor foi escolhido com base nos resultados do Capítulo 4;

- hidrofugante (WR): octiltrietoxisilano solúvel em água, com uma concentração de $10 \%$ em relação à massa de água, e o mesmo utilizado no Capítulo 4;

- hidrofugante e dióxido de titânio aplicados separadamente $\left(\mathrm{WR}+\mathrm{TiO}_{2}\right.$ sequencial): primeiro aplicou-se o hidrofugante e, depois de um minuto, a suspensão de dióxido de titânio. Este método se configura na hipótese fundamental da tese e está baseado nos resultados do Capítulo 4.

Todos os tratamentos superficiais foram aplicados de forma manual com o auxílio de um pincel e sem nenhum tipo de cura posterior. Anteriormente ao tratamento, todas as superfícies foram limpas com um pano umedecido por água, apenas para a retirada de impurezas presentes na superfície.

Em cada etapa deste programa experimental, utilizou-se um ou mais tipos de substratos, sempre tentando mesclar um com alta porosidade e outro com baixa. Isso é possível porque a adesão do hidrofugante à base de silicone ocorre de maneira similar em todos os substratos porosos e silicosos, e porque a adesão do dióxido de titânio ao hidrofugante independe do tipo da base.

$A$ exposição à radiação ultravioleta foi realizada em ambiente com temperatura $e$ umidade controlados a $25^{\circ} \mathrm{C}$ e $100 \%$, respectivamente. A fonte de radiação consistiu de quatro lâmpadas com espectro UV-A, cada qual com potência de $8 \mathrm{~W}$ e 3000 horas de uso, distantes $10 \mathrm{~cm}$ da face dos corpos-de-prova. 


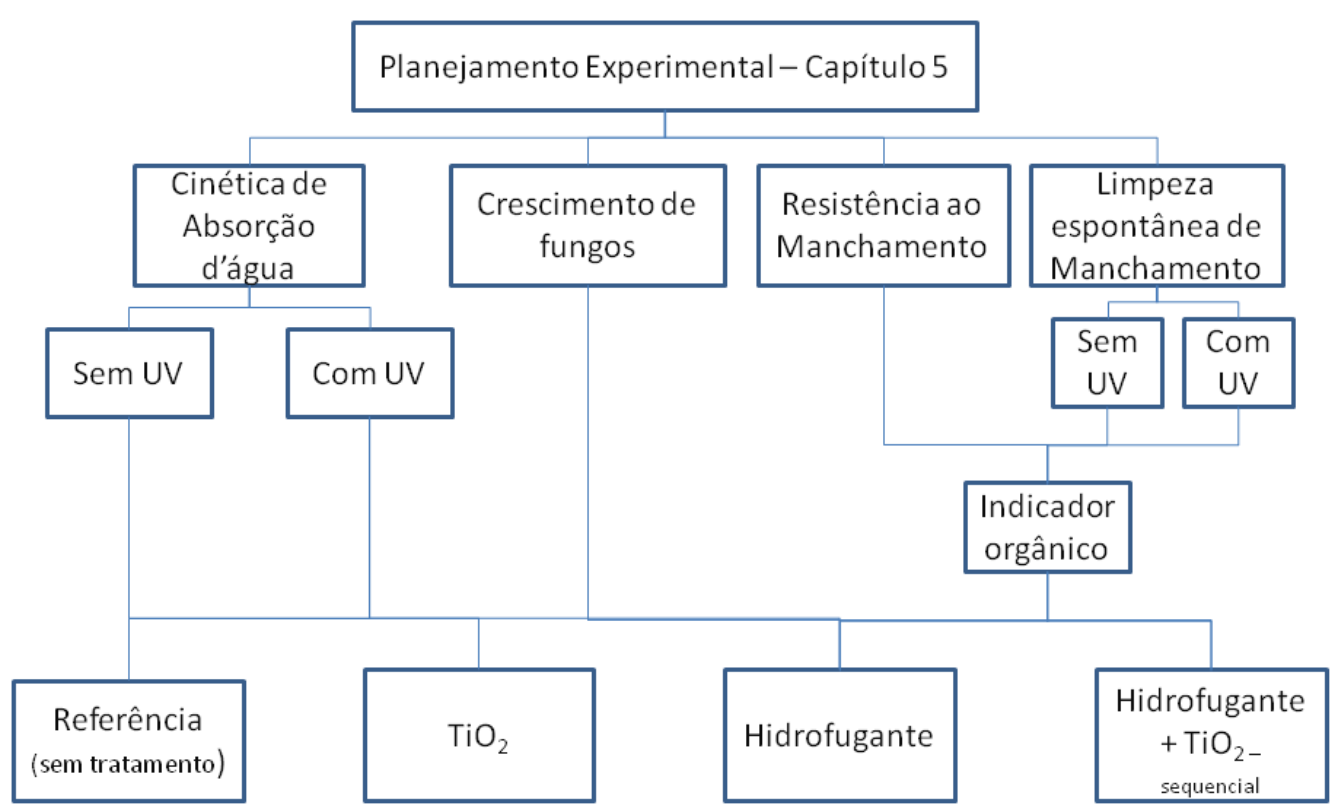

Figura 5- 1: Planejamento Experimental do capítulo 5.

\subsection{Materiais e Métodos}

O dióxido de titânio e o hidrofugante utilizados neste capítulo são os mesmos já caracterizados no Capítulo 4. Não será, portanto, repetido.

Os substratos utilizados nos experimentos foram: fibrocimento sem amianto cortados de telhas comerciais, granito polido proveniente do estado do Ceará e com nome comercial de Branco São Paulo, e duas argamassas.

As placas de fibrocimento tinham dimensões de $3,0 \mathrm{~cm} \times 7,0 \mathrm{~cm} \times 0,4 \mathrm{~cm}$ e uma absorção d'água total de 16,8\%; e as de granito tinham dimensões de $5,0 \mathrm{~cm} \times 5,0 \mathrm{~cm}$ x 2,0m, com uma absorção d'água total é de $0,30 \%$.

Uma das argamassas possui coloração branca, é comercializada pronta para uso e vem sendo aplicada como revestimento de fachada de edifícios (argamassa 1). A outra foi confeccionada, especialmente para esta tese, com cimento CPIII e areia, na proporção de 1:3 (em unidades de massa), um teor de água de $20 \%$ em relação à massa de materiais secos, $1,0 \%$ de aditivo dispersante à base de policarboxilato, e $0,4 \%$ de retentor de água à base MHEC (argamassa 2).

As moldagens das argamassas foram realizadas em fôrmas de isopor não absorvente e com um formato circular de $5,0 \mathrm{~cm}$ de diâmetro. A cura foi realizada em ambiente de laboratório, sem temperatura e umidade controlados, até completarem 28 dias. Depois disso, foram colocados em estufa ventilada por 48 horas a $50^{\circ} \mathrm{C}$ para, só então, receberem os tratamentos superficiais. Depois, voltaram para a estufa ventilada, onde permaneceram por 72 horas na mesma temperatura e umidade supracitada.

Ao término de todo este procedimento foi possível dar início aos ensaios. 


\subsubsection{Cinética de absorção d’ảgua}

Neste ensaio, corpos-de-prova com os diferentes tratamentos superficiais foram imersos em água por um período de dez dias e medidas as variações de massa nos seguintes tempos: 1 minuto, 10 minutos, 1 hora, 24 horas, 72 horas, 240 horas, utilizando uma balança com precisão de 0,01g. A imersão foi realizada em Becker de plástico com uma lâmina d'água, da ordem, de $10 \mathrm{~cm}$.

Para avaliar a influência dos processos fotocatalíticos na cinética de absorção d'água, foram realizados ensaios antes e depois da exposição à radiação ultravioleta com os mesmos corpos-de-prova, sendo que, primeiramente, foram realizados os ensaios antes do UV. Nesse caso, os corpos-de-prova tinham suas laterais seladas com duas demãos de pintura epóxi, obrigando que a penetração da água se dê pelas superfícies

Como substratos, foram utilizados o granito e as duas argamassas. Em ambos, um mínimo de cinco corpos-de-prova de cada tratamento superficial foi ensaiado.

\subsubsection{Crescimento de fungos}

O crescimento de fungos foi avaliado em uma câmara tropical existente na empresa Clariant ${ }^{\circledR}$, seguindo os procedimentos da norma NBR 15301 (ABNT, 2005). Para tal, dois corpos-de-prova de granito e dois fibrocimento de cada tratamento superficial permaneceram a uma temperatura de $28^{\circ} \mathrm{C}$ e uma umidade relativa de $100 \%$ por cerca de 35 dias. Ao longo desse período, a iluminação permaneceu apagada até que se completasse os primeiros 28 dias de teste (Figura 5- 2). As bordas dos corpos-de-prova foram seladas com duas demãos de pintura Epoxi.

A avaliação do crescimento de microorganismos foi realizada pela contagem da área recoberta pelo biofilme, aos 7, 14, 21, 28 e 35 dias.

Anteriormente ao início dos ensaios as superfícies dos corpos-de-prova foram limpas com álcool 70\%, para descontaminação.

Durante o tempo de ensaios, os corpos-de-prova permanecem penduradas em hastes metálicas $75 \mathrm{~mm}$ acima de uma lâmina d'água e distante $50 \mathrm{~mm}$ entre eles. A forma de inoculação foi por aspersão e os tipos de cepas utilizado nos experimentos seguiu as instruções das referida norma, tendo sido usados:

- Aspergillus niger

- Penicillium funiculosum

- Aereobasidium pullulans

- Alternaria alternata

- Cladosporium cladosporioides
ATCC 6275

ATCC 11797

ATCC 9348

ATCC 20084

IMI 178517

Este método de avaliação de fungos recebe duras críticas por ser muito severo e induzir a criação de biofilmes em todos os materiais, não conseguindo avaliar tratamentos superficiais. Isso porque a umidade é mantida muito alta

Apesar disso é um dos métodos mais utilizados em escala laboratorial (Zungo; Hurlow, 2005) e já se mostrou adequado para avaliações de superfícies com 
propriedades fotocatalíticas (Chen et. el., 2009). Além disso, é normalizado no Brasil pela NBR 15301 (ABNT, 2006).
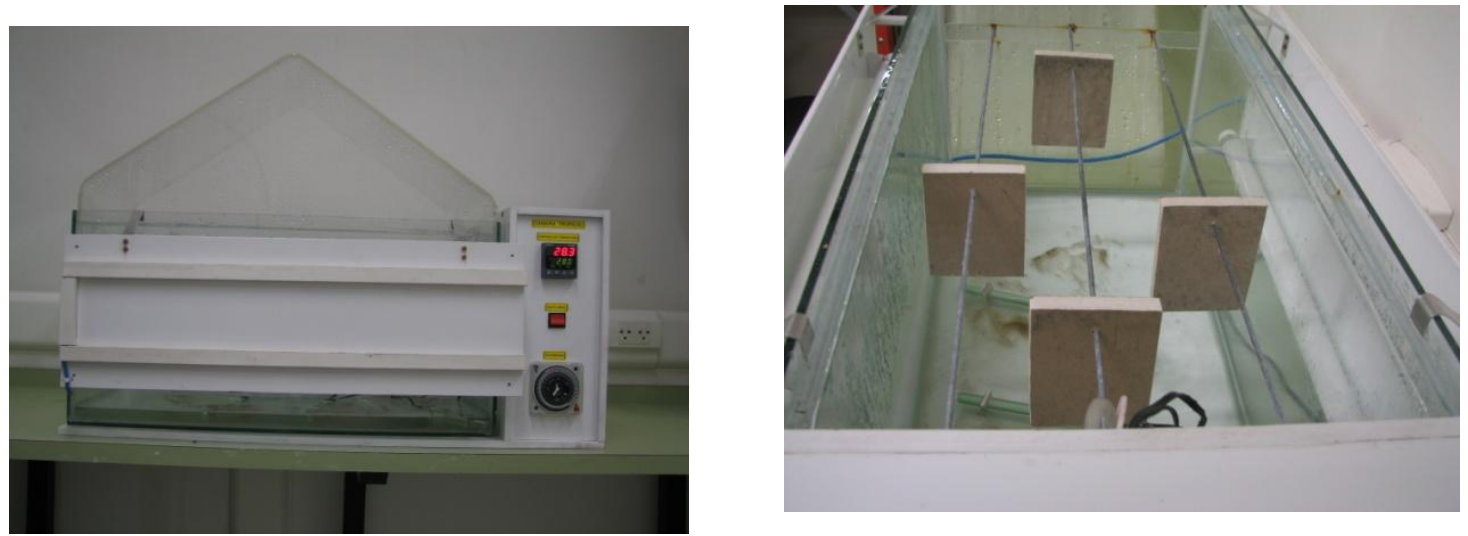

Figura 5- 2: Ilustração da câmara tropical utilizada no programa de avaliação do crescimento de microorganismos.

\subsubsection{Resistência ao Manchamento}

A avaliação da resistência ao manchamento foi realizada por meio do pingamento manual de uma gota com, aproximadamente, $1,0 \mathrm{ml}$ de azul de metileno e anilina vermelha, seguido de uma lavagem com água corrente por cerca de 5 minutos. As avaliações foram realizadas por meio de inspeção visual da área e da intensidade das manchas criadas na superfície dos corpos-de-prova, de forma comparativa entre os diferentes tipos de tratamentos superficiais.

Os dois indicadores orgânicos foram escolhidos por possuírem um caráter apolar (semelhante às partículas de poluição), e apresentarem um elevado contraste de cor com os substratos utilizados nesta fase da pesquisa. Além disso, já são utilizadas para a avaliação da atividade fotocatalítica (Lakshmi et. al.,1995 e Zhang et. al.,2001)

As duas argamassas foram utilizadas como substratos com, no mínimo, dois corpos de prova para cada tratamento superficial.

\subsubsection{Limpeza espontânea de manchamento}

A avaliação da capacidade de limpeza espontânea de manchamentos em substratos porosos e silicosos foi avaliada por meio da alteração de cor de corpos-de-prova da argamassa 1, submetidos à radiação UV, após dois meses de imersão em solução de azul de metileno. Em seguida, os corpos-de-prova foram lavados com água corrente e manualmente esfregados apenas para a retirada de crostas depositadas superficialmente.

A exposição à radiação ultravioleta foi realizada por cerca de dez dias, nas mesmas condições já apresentadas no item 5.2. Ao longo deste período, todos os corpos-deprova tiveram suas superfícies lavadas com água corrente por cerca de 10 segundos pelo menos uma vez ao dia, com o objetivo de retirar partículas degradas pelos processos de oxidação dos agentes manchantes e possibilitar novos processos fotocatalíticos. 


\subsection{Análise dos Resultados}

\subsubsection{Cinética de Absorção D'àgua}

Na Tabela 7 estão apresentados os resultados da absorção total de água após 240 horas de imersão para os três materiais avaliados; já nas Figura 5- 3 e Figura 5- 4 estão os resultados da cinética de absorção d'água da argamassa 1 e do granito, respectivamente. Como as duas argamassas apresentaram uma cinética muito semelhante, apresentam-se apenas os resultados da número 1.

As referências e os tratamentos com suspensão aquosa de $\mathrm{TiO}_{2}$ apresentam um comportamento semelhante: maior absorção total d'água e uma cinética caracterizada por grande ganho de massa logo nas primeiras horas, onde mais de $75 \%$ do total é identificado na primeira hora.

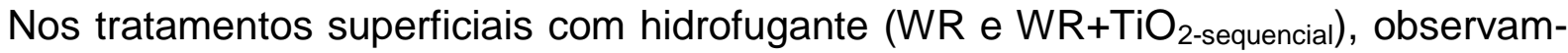
se importantes reduções na absorção total de água dos três materiais avaliados. Nas argamassas, o seu efeito foi menos importante, possibilitando reduções entre $8 \%$ e $21 \%$, se comparado à referência, enquanto que nos granitos essas reduções chegaram a 40\%. Os dois tratamentos apresentaram cinéticas semelhantes.

A exposição à radiação ultravioleta não causou efeito significativo. As diferenças identificadas podem ser atribuídas ao método de ensaio adotado (diferença de massa) e, especificamente para as argamassas, à redução da porosidade da hidratação da matriz cimentícia, uma vez que foram utilizados os mesmos corposde-prova nos testes antes e depois da exposição ao UV.

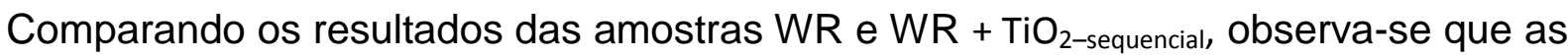
maiores diferenças encontradas no perfil das curvas estão concentradas na primeira hora de imersão em água, onde a exposição à radiação ultravioleta produziu uma aceleração do ganho de massa nas amostras tratadas com hidrofugante e dióxido de titânio (Figura 5- 5).

Este comportamento pode ser atribuído a uma redução do ângulo de contato causada pelos processos fotocatalíticos do semicondutor, com consequente aumento da tensão superficial. Além disso, seu efeito apenas na primeira hora comprova que o tratamento superficial $\mathrm{WR}+\mathrm{TiO}_{2}$ - sequencial exerce influência apenas na camada mais externa do substrato, e que o uso de titânio não modifica o comportamento do hidrofugante que revestem os poros no corpo dos materiais silicosos e porosos.

Não foram encontradas outras referências que sirvam de comparação aos resultados encontrados nesta tese. 
Tabela 7: Valores de absorção total de água após o término dos ensaios.

\begin{tabular}{|c|c|c|c|c|c|c|c|}
\hline \multicolumn{8}{|c|}{ Absorção Total D'água por Imersão } \\
\hline & & \multicolumn{2}{|c|}{ Granito } & \multicolumn{2}{|c|}{ Argamassa 1} & \multicolumn{2}{|c|}{ Argamassa 2} \\
\hline & & $\begin{array}{l}\text { Antes } \\
\text { do UV }\end{array}$ & $\begin{array}{l}\text { Depois } \\
\text { do UV }\end{array}$ & $\begin{array}{l}\text { Antes } \\
\text { do UV }\end{array}$ & $\begin{array}{l}\text { Depois } \\
\text { do UV }\end{array}$ & $\begin{array}{l}\text { Antes } \\
\text { do UV }\end{array}$ & $\begin{array}{l}\text { Depois } \\
\text { do UV }\end{array}$ \\
\hline \multirow[b]{2}{*}{ Referência } & média & $0,25 \%$ & $0,22 \%$ & $16,1 \%$ & $15,5 \%$ & $15,5 \%$ & $15,3 \%$ \\
\hline & desvio padrão & $0,07 \%$ & $0,08 \%$ & $0,9 \%$ & $0,9 \%$ & $0,3 \%$ & $0,5 \%$ \\
\hline \multirow[b]{2}{*}{$\mathrm{TiO}_{2}$} & média & $0,24 \%$ & $0,23 \%$ & $16,7 \%$ & $15,4 \%$ & $14,5 \%$ & $14,5 \%$ \\
\hline & desvio padrão & $0,02 \%$ & $0,02 \%$ & $0,70 \%$ & $1,0 \%$ & $0,7 \%$ & $1,3 \%$ \\
\hline \multirow[b]{2}{*}{ WR } & média & $0,15 \%$ & $0,17 \%$ & $11,1 \%$ & $10,5 \%$ & $12,6 \%$ & $12,7 \%$ \\
\hline & desvio padrão & $0,03 \%$ & $0,01 \%$ & $2,1 \%$ & $1,1 \%$ & $0,9 \%$ & $1,2 \%$ \\
\hline \multirow{2}{*}{$\begin{array}{l}\mathrm{WR}+\mathrm{TiO}_{2} \\
\text { sequencial }\end{array}$} & média & $0,22 \%$ & $0,16 \%$ & $13,3 \%$ & $12,2 \%$ & $14,3 \%$ & $12,8 \%$ \\
\hline & desvio padrão & $0,01 \%$ & $0,03 \%$ & $2,1 \%$ & $1,6 \%$ & $0,8 \%$ & $0,7 \%$ \\
\hline
\end{tabular}
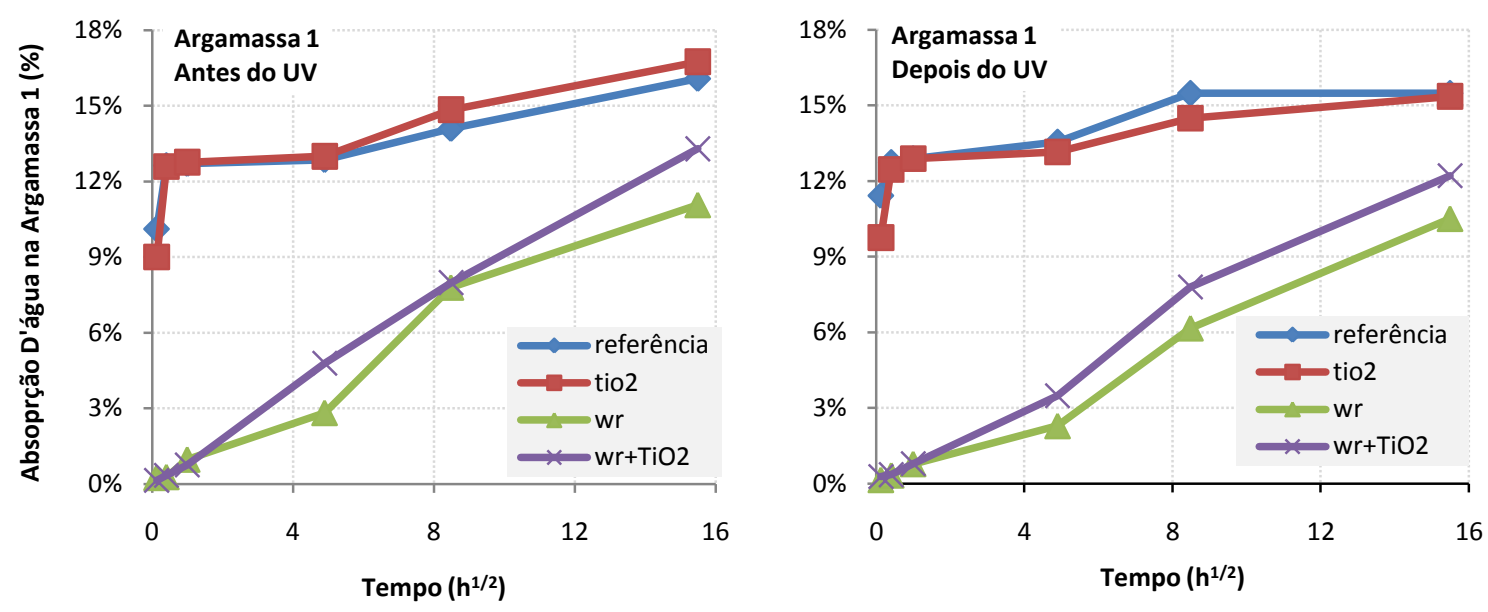

Figura 5- 3: Resultados de absorção de água no substrato da argmassa 1.
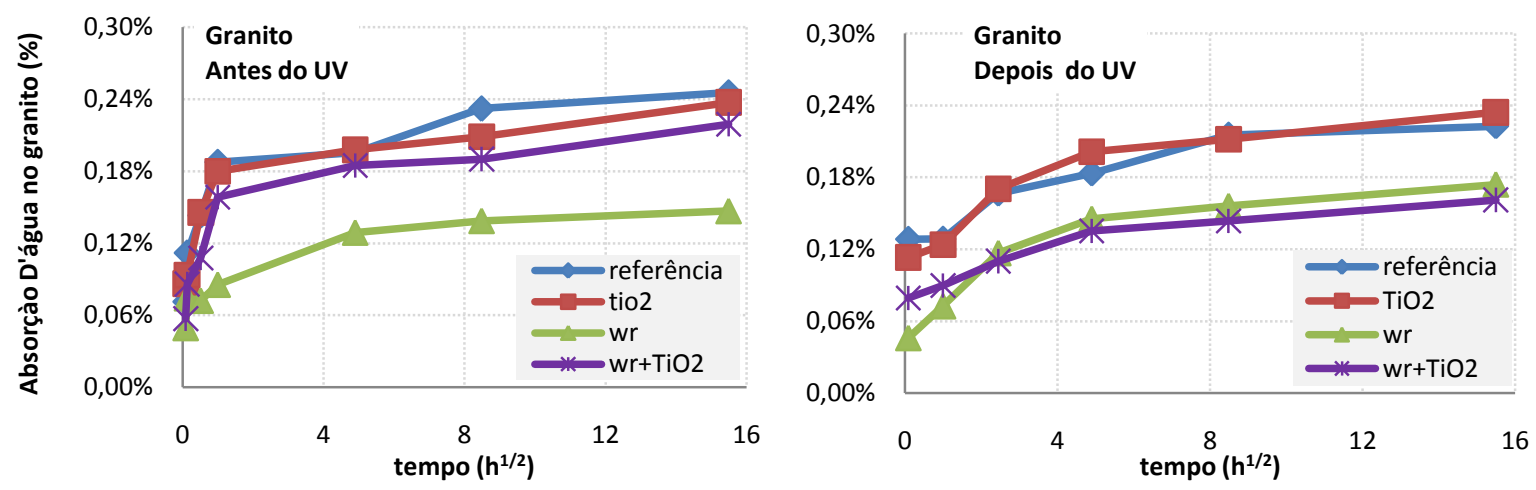

Figura 5- 4: Resultados de absorção de água no substrato no granito. 


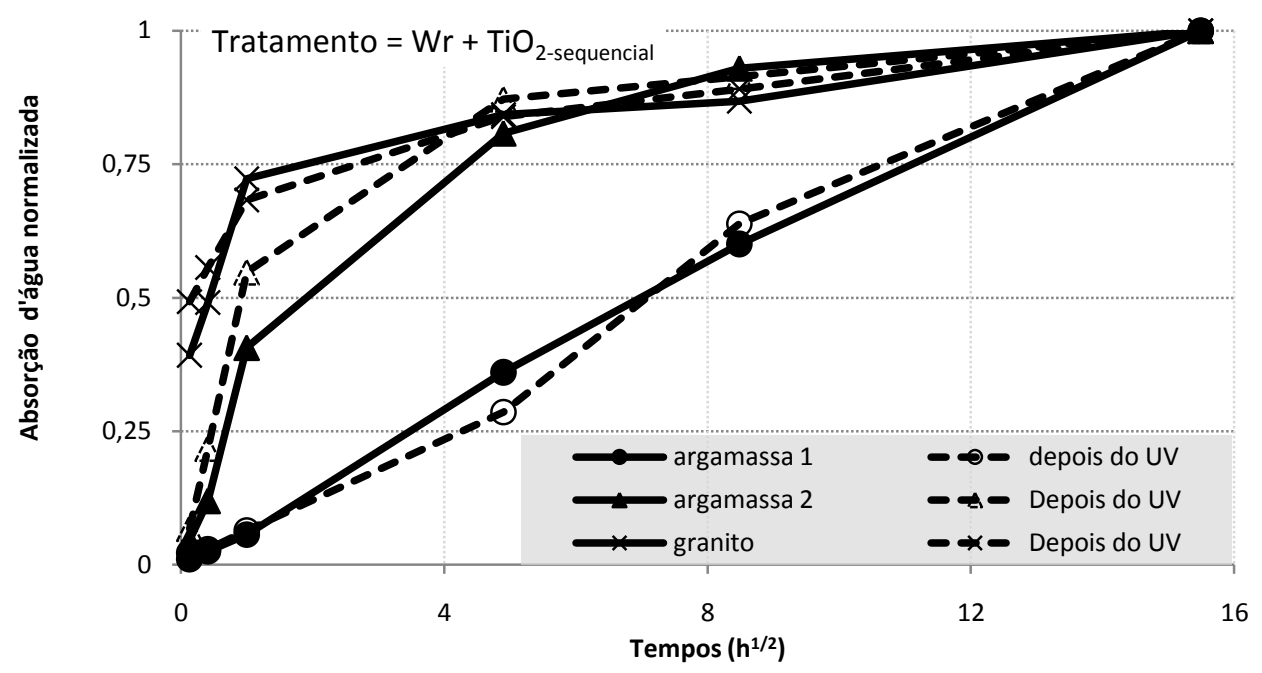

Figura 5- 5: Absorção percentual de água para a amostra $\mathrm{WR}+\mathrm{TiO}_{2 \text {-sequencial. }}$

\subsubsection{Crescimento de Fungos}

$\mathrm{Na}$ Tabela 8 estão apresentados os resultados da proliferação acelerada de microorganismos.

Os resultados indicam que as amostras de granito e fibrocimento sem tratamento superficial apresentam as maiores áreas recobertas pelo biofilme após os trinta e cinco dias de ensaio (entre $10 \%$ e $25 \%$ da superfície), enquanto que, onde houve a união entre o hidrofugante e o dióxido de titânio, não se constatou qualquer tipo de crescimento. Os outros tratamentos apresentam resultados intermediários.

Os resultados aqui encontrados confirmam que em substratos porosos, o simples tratamento superficial com uma suspensão aquosa de $\mathrm{TiO}_{2}$ fotoativado é insuficiente para barrar o crescimento de microorganismos em escala laboratorial, uma vez que a velocidade de crescimento de fungos é superior à capacidade de oxidação das superfícies fotoativadas. Resultados semelhantes com suspensões de dióxido de titânio foram previamente encontrados por Chen et. al., 2009, em substratos de madeira, e por Kurth (2008), para o caso de argamassas. Os autores citados não avaliaram união entre hidrofugantes e o semicondutor. 
Tabela 8: Resultados do crescimento acelerado de microorganismos na câmara tropical. Cada número se refere a um corpo-de-prova.

\begin{tabular}{|c|c|c|c|c|c|c|}
\hline \multicolumn{2}{|l|}{ Amostra } & 7 dias & 14 dias & 21 dias & 28 dias & 35 dias \\
\hline \multirow{4}{*}{ Granito } & Sem Tratamento & $0 / 0$ & $0 / 0$ & $0 / 0$ & $0 / 0$ & $2 / 2$ \\
\hline & WR & $0 / 0$ & $0 / 0$ & $0 / 0$ & $0 / 0$ & $0 / 1$ \\
\hline & $\mathrm{TiO}_{2}$ & $0 / 0$ & $0 / 0$ & $0 / 0$ & $0 / 0$ & $0 / 1$ \\
\hline & $\mathrm{WR}+\mathrm{TiO}_{2}$ & $0 / 0$ & $0 / 0$ & $0 / 0$ & $0 / 0$ & $0 / 0$ \\
\hline \multirow{4}{*}{ Fibrocimento } & Sem Tratamento & $0 / 0$ & $0 / 0$ & $0 / 0$ & $0 / 0$ & $1 / 2$ \\
\hline & WR & $0 / 0$ & $0 / 0$ & $1 / 0$ & $1 / 1$ & $1 / 1$ \\
\hline & $\mathrm{TiO}_{2}$ & $0 / 0$ & $0 / 0$ & $0 / 0$ & $0 / 1$ & $0 / 1$ \\
\hline & $\mathrm{WR}+\mathrm{TiO}_{2}$ & $0 / 0$ & $0 / 0$ & $0 / 0$ & $0 / 0$ & $0 / 0$ \\
\hline
\end{tabular}

0 : Crescimento de fungo não detectado;

1: Crescimento de fungo em até $10 \%$ da superfície do corpo-de-prova;

2: Crescimento de fungo entre $10 \%$ e $25 \%$ da superfície do corpo-de-prova;

3: Crescimento de fungo entre $25 \%$ e $50 \%$ da superfície do corpo-de-prova;

4: Crescimento de fungo entre $50 \%$ e $75 \%$ da superfície do corpo-de-prova;

5: Crescimento de fungo superior a $75 \%$ da superfície do corpo-de-prova.

\subsubsection{Resistência ao Manchamento}

Nas Tabela 9 e na Tabela 10 estão apresentados os manchamentos característicos na argamassa 1 e argamassa 2, respectivamente, causados pela deposição de azul de metileno e anilina vermelha, em três momentos do ensaio: inicial, um minuto depois do pingamento do agente manchante e após a lavagem com água corrente.

Os resultados mostram que as duas argamassas apresentam comportamentos semelhantes. Os tratamentos que contém hidrofugante à base de silicone (WR e WR $+\mathrm{TiO}_{2 \text {-sequencial }}$ ) apresentam uma maior resistência ao manchamento e possibilitam que a lavagem em água corrente por 5 minutos retire, quase por completo, o agente manchante. Ao término deste procedimento restam, apenas, pequenos resquícios em pontos isolados.

Por outro lado, na referência e onde houve tratamento com suspensão de $\mathrm{TiO}_{2}$, observa-se um grande espalhamento e absorção do agente manchante, fazendo com que a lavagem com água corrente não consiga eliminar a mancha. Ao término dos ensaios restam manchas de coloração intensa que recobrem mais de $70 \%$ da superfície das argamassas. 
Tabela 9: Resltados característicos de resistência ao manchamento na Argamassa 1 - comprada pronta para o uso.

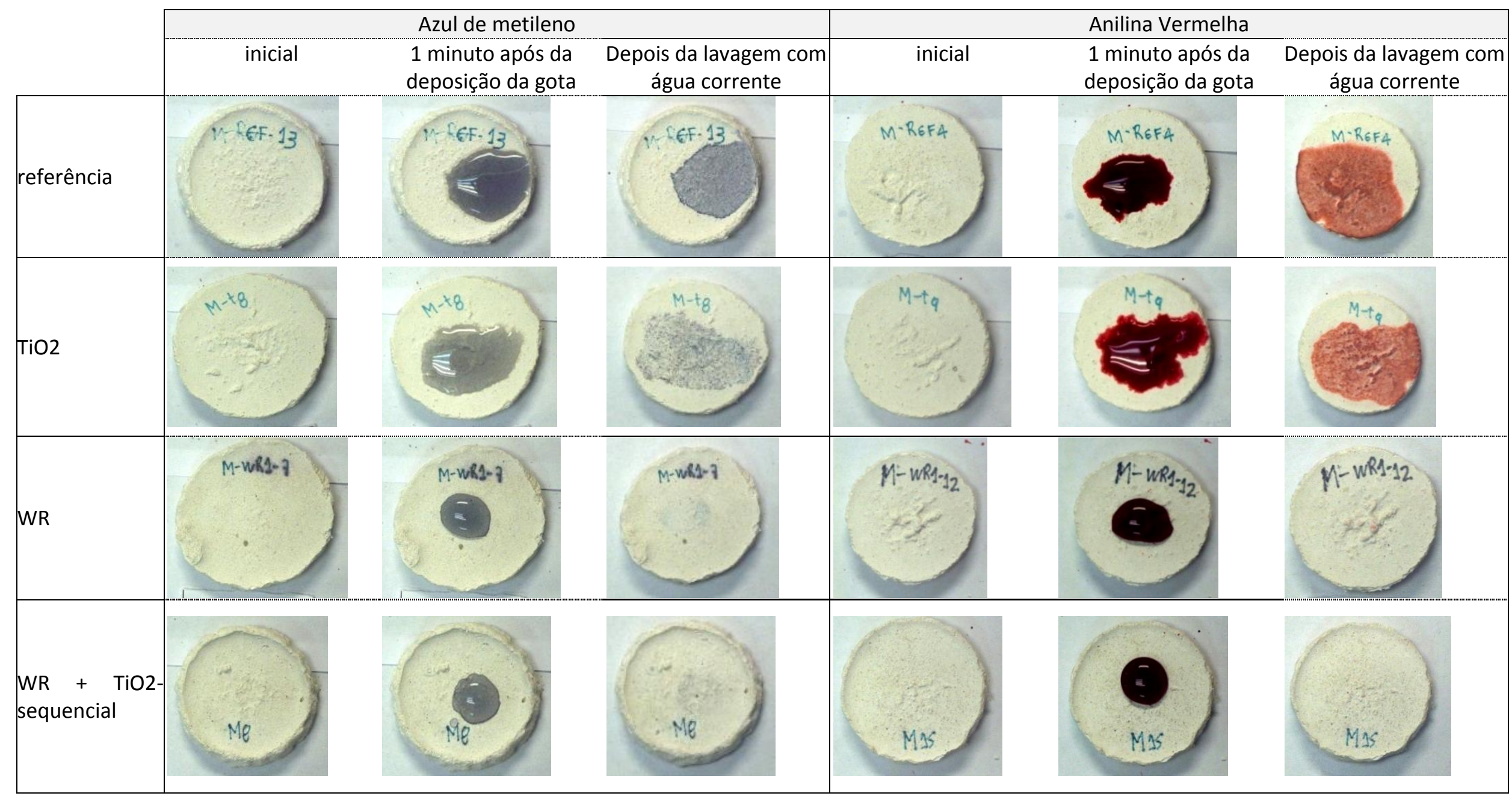


Tabela 10: Resultados característicos de resistência ao manchamento na Argamassa 2 - dosada especificamente para a tese.

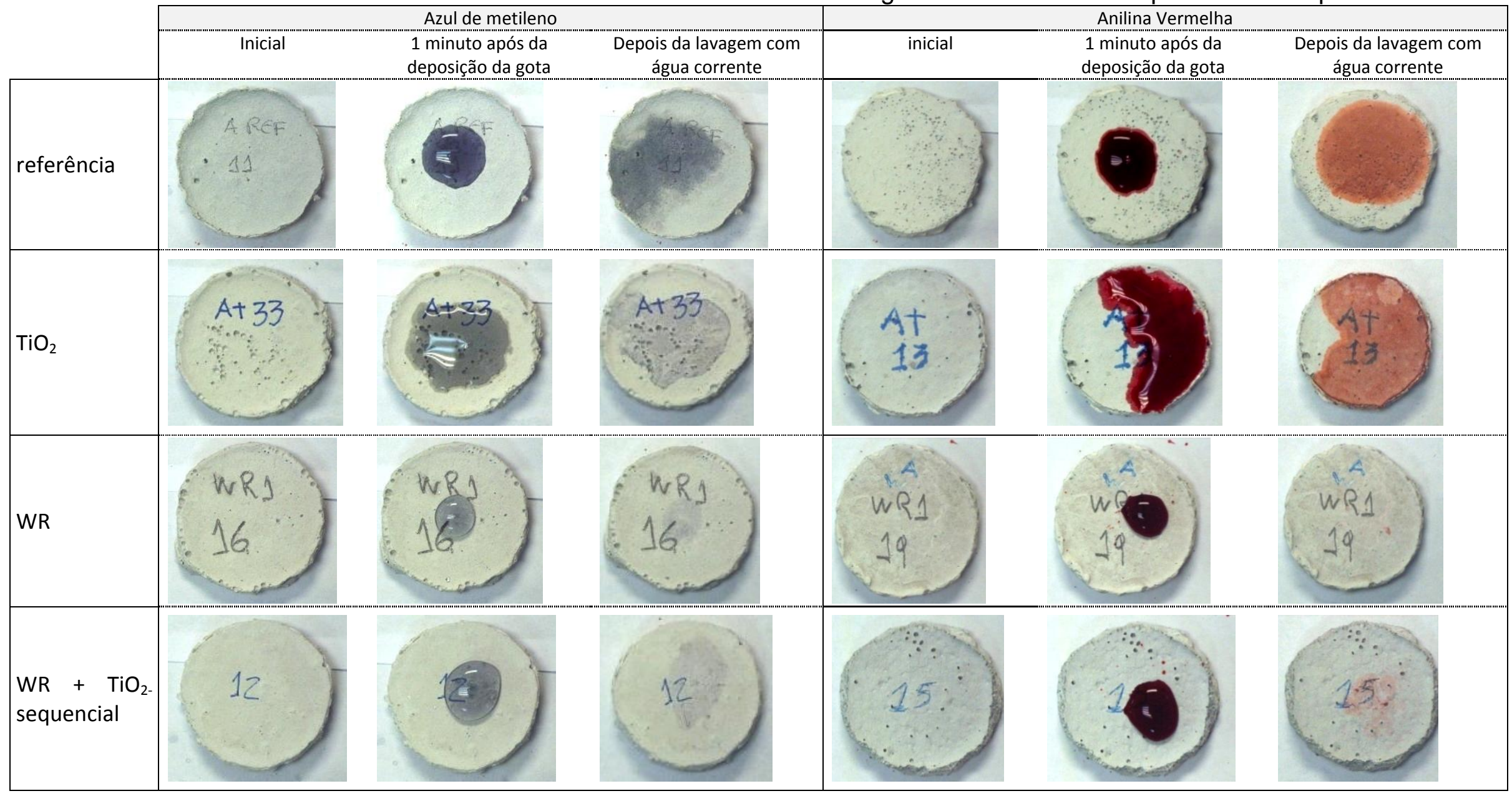




\subsubsection{Limpeza Espontânea do Manchamento}

Após dois meses de imersão em solução de azul de metileno todos os corpos-deprova apresentaram importante manchamento superficial, sendo que os menos intensos são verificados na amostra $\mathrm{WR}+\mathrm{TiO}_{2 \text {-sequencial }}$ (Tabela 11). Além disso, a lavagem com água corrente, seguida da exposição à radiação ultravioleta por dez dias, foi responsável por importantes reduções na área e na intensidade das manchas em todas as amostras.

A amostra de referência e a amostra tratada apenas com hidrofugante são as menos influenciadas pela exposição à radiação ultravioleta. Em ambas, o tempo de ensaio foi insuficiente para degradar o agente manchante e, após o término dos ensaios, persistem grandes áreas com manchas azuladas de intensidade forte.

Por sua vez, nas amostras em que há dióxido de titânio no tratamento superficial

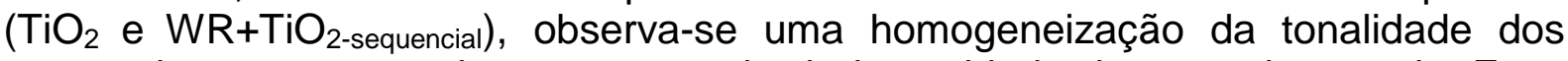
corpos-de-prova e uma importante perda de intensidade das manchas azuis. Esse efeito pode ser atribuído à atividade fotocatalítica do semicondutor que acelera a degradação do agente manchante, e tem seus resíduos lixiviados pela água corrente aplicada diariamente.

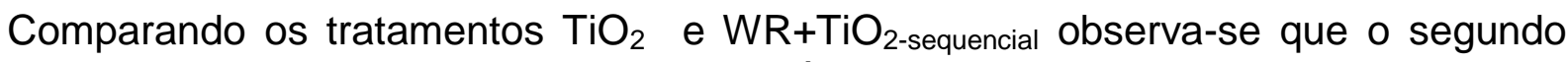
apresentou uma melhor limpeza espontânea do agente manchante, porque a presença do hidrofugante reduz a sua penetração nos poros da argamassa, e o semi-condutor consegue ser foto-ativado pela incidência de radiação UV. Isso confirma os resultados de absorção d'água e atividade fotocatalítica, já apresentados nesta tese.

Como consequência, após os dez dias de ensaio a superfície dos corpos-de-prova estão, praticamente, retornando à sua coloração original. Restam apenas manchas pontuais localizadas nas fissuras superficiais onde, possivelmente, não há o tratamento superficial.

Esses resultados estão concordantes com diversos outros já publicados como Yurunova et. al. (2007). 
Tabela 11: Resultados característicos dos ensaios de limpeza espontânea de manchamento após a exposição radiação UV.

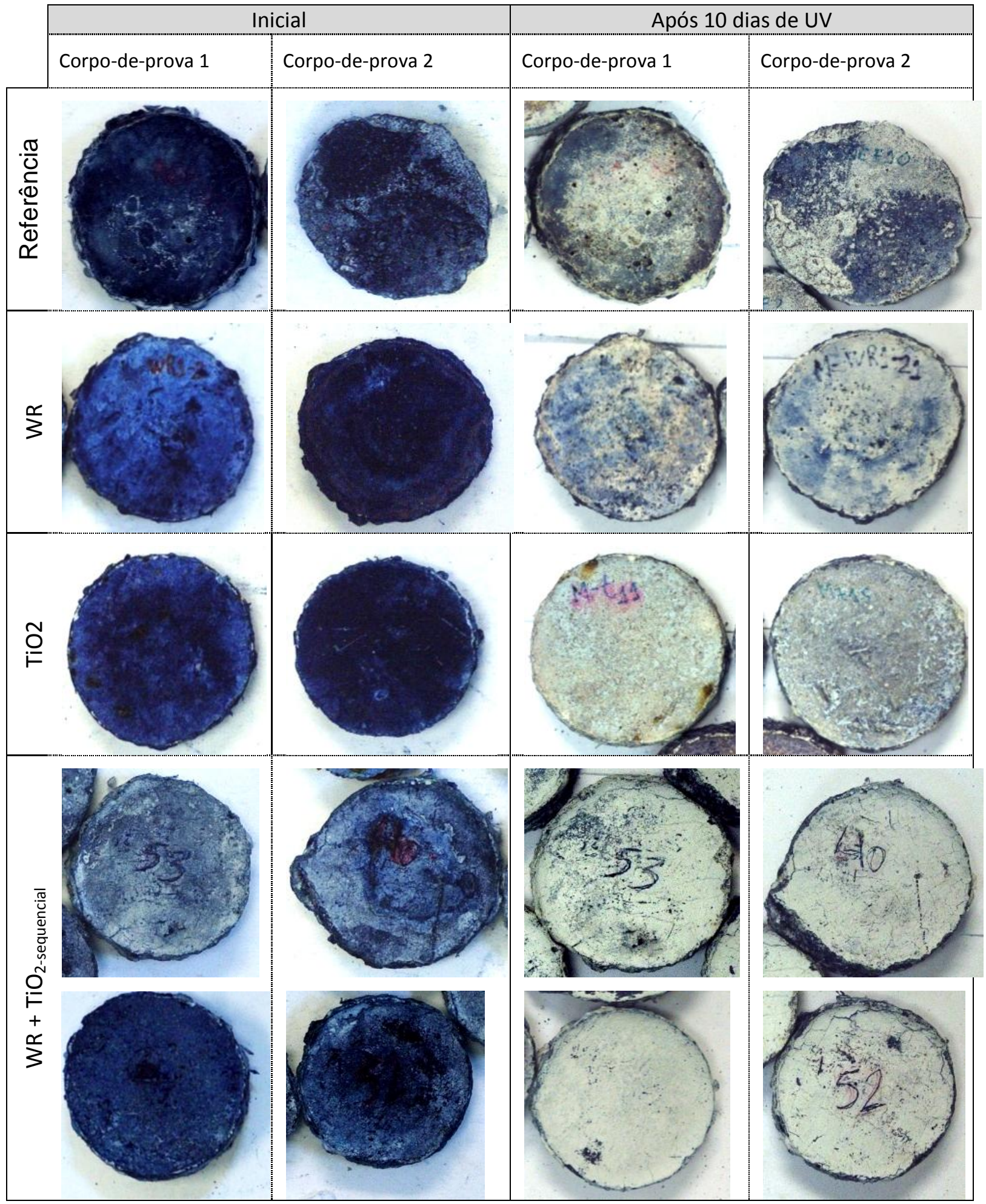




\subsection{Conclusões do Capitulo}

O tratamento superficial dos materiais de construção porosos e silicosos com um hidrofugante à base de silicone e dióxido de titânio, aplicados de maneira sequencial, apresenta uma elevada resistência à adesão de agentes manchantes apolares e uma elevada capacidade de limpeza espontânea, pela simples presença de radiação ultravioleta e água.

Além disso, esse método mostrou-se efetivo na redução do teor de umidade dos materiais de construção, fazendo com que sua cinética seja semelhante à dos materiais tratados apenas com hidrofugante. A única diferença significativa está concentrada na primeira hora de imersão onde a redução do ângulo de contato, confirmada no Capítulo 5, aumenta as forcas dos capilares superficiais e aceleram a entrada de água na forma líquida.

Como consequencia, o tratamento superficial com dióxido de titânio e hidrofugante inibiu a proliferação de microorganismos em escala laboratorial, tanto para os substratos de granito quanto para o fibrocimento sem amianto.

Extrapolando esses resultados para a escala das vedações externos dos edifícios, é de se esperar uma redução no surgimento redução de manchas causadas pela deposição de partículas de poluição, que também são apolares nos grandes centros urbanos, e pela proliferação de microorganismos, que está diretamente relacionada com a ação da água na forma líquida. 


\section{CAPÍtULO VI}

\section{Conclusões}

A alteração de cor na superfície das edificações causa importante degradação no ambiente construído e exige grandes esforços de recuperação, por parte dos usuários e da sociedade como um todo. Por isso, a demanda por alternativas que modifiquem este ciclo e consigam reduzir a freqüência e a intensidade das atividades de manutenção é cada vez maior.

Neste sentido, desenvolveu-se esta tese de doutoramento cujo objetivo principal foi criar um método capaz de barrar a proliferação de microorganismos e a deposição de partículas de poluição, que, juntos, formam as manchas nas vedações externas. Isso se mostrou necessário porque as alternativas, atualmente disponíveis para os materiais de construção silicosos e porosos, não vêm apresentando um desempenho satisfatório; seja porque não barram a deposição de partículas de poluição, caso da hidrofugação; seja porque não consegue inibir a crescimento de microorganismos, como a fotocatálise e os pigmentos frios.

Esse novo método deveria, ainda, atender aos seguintes pré-requisitos, para que seja mais fácil e rapidamente aplicabilidade na construção civil: (i) ser aplicado como um pós-tratamento; (ii) não necessitar de cura especial após sua aplicação; (iii) ser transparente; (iv) apresentar boa aderência ao substrato e suporte processos de abrasão; e (v) inibir/prevenir, efetivamente, o surgimento de manchas.

Para atender a todas essas demandas, partiu-se da hipótese de que uma maneira eficiente para se evitar/reduzir as manchas nas vedações externas dos edifícios é produzir superfícies que apresentem um comportamento hidrofóbico, mas com propriedades fotocatalíticas, quando incididos por radiação ultravioleta.

Essa hipótese apresenta uma característica inovadoras, necessárias à uma tese de doutorado, uma vez que, não se tem conhecimento de materiais de construção com essas propriedades. Principalmente nos materiais silicosos e porosos, que são os mais utilizados para a produção de vedações externas nos edifícios brasileiros.

Para testar o método proposto, foi utilizada uma metodologia sequencial de ensaios laboratoriais, onde a resposta de uma etapa já serve de subsídio para a fase seguinte. Apesar de não convencional, essa metodologia está baseada na pesquisaação, que já tem longa tradição na área de ciências sociais e de administração; e possui como grande vantagem, a possibilidade de manipulação de diversas variáveis simultaneamente dando peso, também, aos resultados qualitativos que são obtidos ao longo da pesquisa.

Isto tudo permitiu desenvolver um método que se baseia na sobreposição de camadas. Na parte mais externa ficam depositados semicondutores à base de dióxido de titânio e no corpo do material poroso está depositado o hidrofugante à base de silicone. A ligação entre essas duas camadas é feita pela liberação do 
radical silanol $(\mathrm{SiOH})$ do hidrofugante durante 0 seu processo de hidrólise/condensação e posterior ligação à superfície do dióxido de titânio hidrolisada. Esse mesmo radical já vem sendo com o mesmo fim na área de filmes poliméricos, sendo que nesses casos sua origem é a sílica coloidal.

Ocorre, porém, que para que ocorra um adequado funcionamento do método proposto, é necessário aplicar os dois produtos de maneira separada (denominada na tese por sequencial). Isto induz que as partículas do semicondutor sejam depositadas sobre os radicais apolares do hidrofugante permitindo que a fotoativação aconteça quando há incidência de radiação UV.

Assim, o método proposto nessa tese apresenta, comprovadamente, os seguintes benefícios:

- redução de manchas causadas pela adesão de partículas com características apolares, similares às partículas de poluição dos grandes centros urbanos;

- limpeza espontânea de certos tipos de manchas, decorrentes dos processos fotocatalíticos que promovem a oxidação/redução de matéria orgânica;

- inibição do crescimento de microrganismo em escala laboratorial;

- redução da absorção total de água e, principalmente, da cinética do ganho de massa.

Conclui-se, então, que o método desenvolvido nesta tese conseguiu barrar ou, no mínimo, reduzir o surgimento de manchas nos materiais de construção porosos e silicosos e, com isso, atender ao objetivo principal e a hipótese traçados inicialmente.

Apesar disso, algumas dificuldades intrínsecas do método proposto ficam latentes e precisam ser resolvidas para que possa ser aplicado nas vedações externas de um edifício.

A primeira está ligada à escala dos ensaios realizados na pesquisa. Como todo o desenvolvimento da tese foi realizado em escala laboratorial, não se pode afirmar que haverá uma reprodutibilidade exata dos bons resultados aqui encontrados quando o método for aplicado na escala do edifício. Variações são esperadas e precisam ser compreendidas anteriormente à disseminação do método.

A segunda está ligada à durabilidade. Conforme destacado no capítulo 3 , um dos grandes problemas da fotocatálise, atualmente, reside nas incertezas quanto à sua durabilidade quando em condições de serviço. Esta tese pouco contribuiu neste sentido, uma vez que as avaliações realizadas foram todas de curta duração.

Até se tentou evoluir neste tema e realizou-se a exposição de corpos-de-prova de fibrocimento, argamassa, cerâmica e granito, ao envelhecimento natural por seis meses na cidade de São Paulo. Ocorre, porém, que as diferenças obtidas até o momento da finalização da tese, entre os tratamentos superficiais avaliados, ainda não são conclusivas e, portanto, não puderam ser incorporadas nesse documento.

Apesar disso, é de se destacar que os corpos-de-prova que ficaram em ambiente protegido da incidência direta de radiação solar apresentaram as maiores taxas de manchamento, causados, principalmente, pelo crescimento de microrganismo de cor verde. Neste caso, os corpos-de-prova tratados com hidrofugante e dióxido de titânio

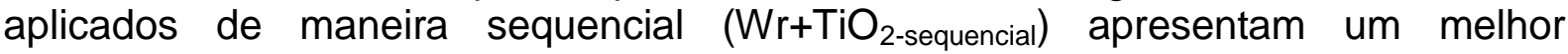


desempenho quando comparado à referência e ao tratamento com suspensão aquosa de $\mathrm{TiO}_{2}$ (Figura 6- 1).

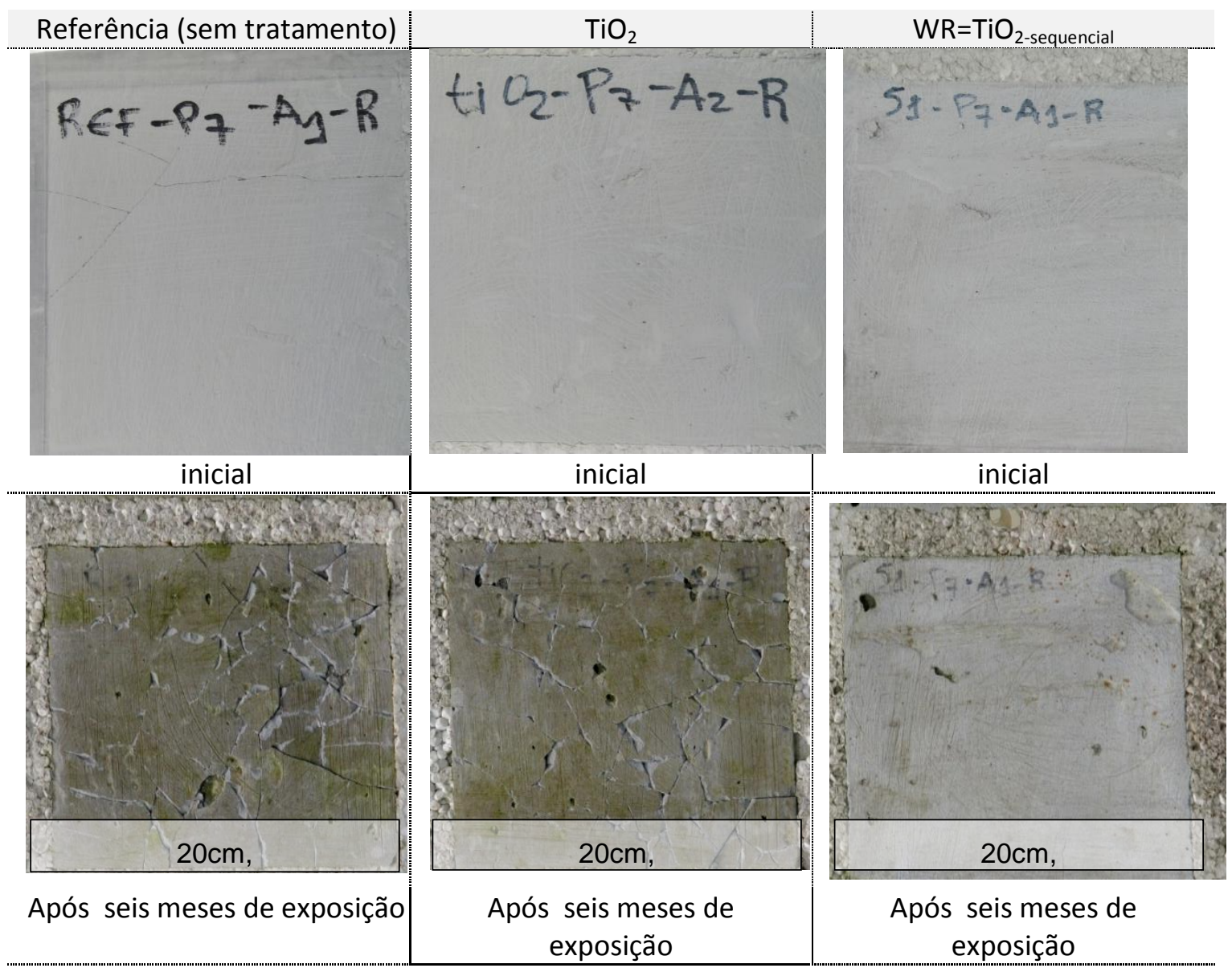

Figura 6- 1: Comparação entre o manchamento superficial de corpos-de-prova de argamassa após seis meses de exposição na cidade de São Paulo. Notar que as áreas verdes na referência e no $\mathrm{TiO}_{2}$ representam microrganismos. As quebras foram causadas por chuva de granizo ocorrida durante 0 ensaio.

A terceira limitação está ligada ao hidrofugante. Como foi utilizado apenas um produto, com uma única concentração fica difícil extrapolar o comportamento observado para outros produtos. Além disso, trata-se de um produto comercial onde alterações na sua formulação, pelo próprio fabricante, pode vir a modificar seu comportamento.

A quarta limitação está ligada ao dióxido de titânio. Como o teor utilizado nos experimentos $(1,0 \% \mathrm{w} / \mathrm{w})$ está baseado na deposição de aglomerados, com tamanho de partícula centenas de vezes superior ao original, conforme comprovado no capítulo 4, é de se esperar que se possa utilizar concentrações superiores sem que surjam manchas de aplicação na superfície dos materiais de construção. Apesar disso, o método de dispersão aqui usado possibilitou a obtenção de superfícies com propriedades fotocatalíticas suficientes para barrar as manchas.

A quinta, e última, limitação está ligada ao método desenvolvido, propriamente dito. A defasagem de um minuto entre a aplicação do hidrofugante e do semicondutor é 
difícil de ser reproduzida em campo e, nessa tese, não foi avaliado o impacto de se utilizar períodos de tempo diferentes. O que se pode afirmar, é que só ocorrerão as ligações químicas e a sobreposição, efetiva, de camadas aqui conseguidas, enquanto houver radicais silanol livres durante o processo de policondensação do hidrofugante. Esse tempo é menor para os silanos e maior para os siloxanos.

Apesar de todas essas limitações, o método proposto na tese se constitui em uma importante via de transformação das edificações, no sentido de contribuir, efetivamente, para a sustentabilidade do ambiente construído.

Isto porque, segundo toda a bibliografia consultada, a fotocatálise vem sendo largamente pesquisada para despoluição de grandes centros urbanos e o método aqui proposto, comprovadamente, apresenta atividade fotocatalítica quando incidido por radiação UV. Desta forma, é de se esperar que um material cuja superfície apresente as propriedades do método proposto consiga se tornar um agente de despoluição ambiental efetivo e reduza a concentração de $\mathrm{SO}_{x}$ e $\mathrm{NO}_{x}$ da atmosfera das grandes cidades.

Além disso, a redução de escurecimento das vedações externas e da absorção d'água, permite uma redução dos gastos nas atividades de manutenção e no consumo de energia das edificações.

Desta forma, é de se esperar que edificações que usem materiais de construção em suas vedações externas, tratadas superficialmente com o método proposto, tornemse células ativas para a sustentabilidade do ambiente construído: reduzindo o consumo de energia, reduzindo os custos de manutenção e despoluindo a atmosfera.

Apesar de ter sido vencida esta etapa, a alteração das propriedades superficiais dos materiais de construção pode ser, ainda, bastante melhorada. Principalmente se forem incorporados os conceitos de tribologia e química de superfície, de modo que haja uma rugosidade superficial semelhante à da folha de lótus, e seja introduzida uma nova camada constituída de partículas com elevada refletividade de radiação infra-vermelho (Figura 6- 2).

Uma superfície com estas características, potencialmente, vai se tornar ainda mais efetiva na redução de manchas, visto que tem atuação tanto com ultravioleta, por conta da fotocatálise, quanto sem, por conta do efeito lótus. Além disso, irá absorver menos calor durante o dia e, com isso, reduzir os riscos de condensação. 


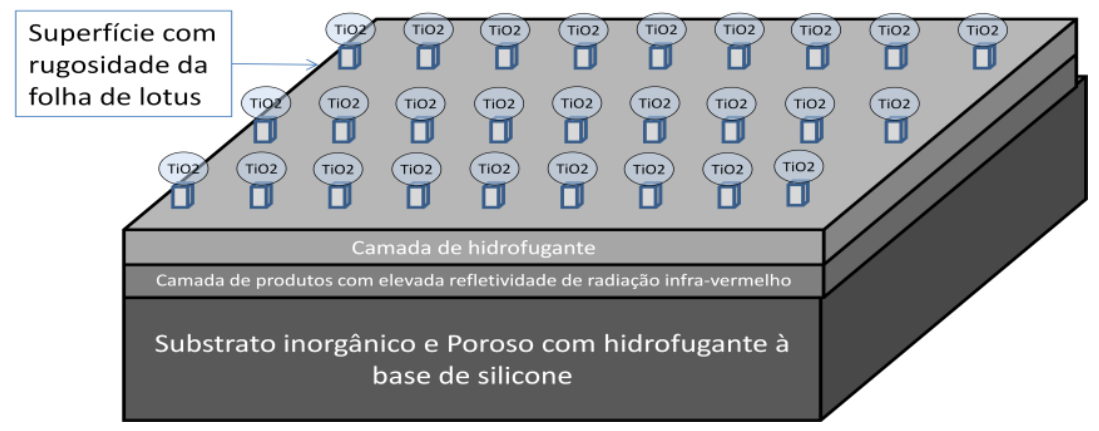

Figura 6- 2: Sugestão de superfície que une a fotocatálise, super-hidrofugação com o efeito lótus e pigmentos frios.

\subsection{Sugestốes para Traballhos Futuros}

Por existirem poucos estudos sobre o tema de prevenção de manchas nas vedações externas dos edifícios existem muitas áreas ainda inexploradas, e que guardam um grande potencial de desenvolvimento. Dentre elas acredita-se que os temas a seguir apresentados sejam de grande importância para a evolução tecnológica dessa área de conhecimento.

Muitas das sugestões aqui apresentadas buscam responder às limitações destacadas no item anterior. Outras extrapolam o tema, propriamente dito, e visam novas aplicações.

Os principais temas sugeridos são:

- investigar a durabilidade do método proposto quando exposto às condições normais de serviço. Para tal, deve ser prevista a aplicação em escala piloto onde é possível realização avaliações periódicas;

- desenvolver o micro-encapsulamento do semicondutor e do hidrofugante, viabilizando a aplicação dos materiais em uma única etapa, mas mantendo a sobreposição das camadas;

- investigar o uso de novos semicondutores e da dopagem;

- Investigar o uso de novos hidrofugantes que consigam fornecer propriedades semelhantes às obtidas pelo octil-silicone usado nessa tese;

- investigar o uso da fotocatálise como instrumento de saúde pública. Como existe uma correlação direta entre a concentração de poluição na atmosfera e a taxa de internamento hospitalar por problemas respiratórios nas grandes cidades, já comprovados em São Paulo ${ }^{11}$, e como a fotocatálise consegue reduzir a taxa de óxidos de enxofre e nitrogênio da atmosfera, é de se esperar a aplicações em larga escala do método possibilite, efetivamente, para a melhoria da qualidade do ar;

- investigar nos métodos de dispersão do semicondutor, com o objetivo de reduzir a formação e deposição de aglomerados;

- desenvolver o método proposto para que se torne, efetivamente, antipichação. Isto porque as alternativas hoje disponíveis para a prevenção de

\footnotetext{
11 http://www.agencia.fapesp.br/materia/11125/peso-da-poluicao.htm, acessado no dia 28 de setembro de 2009
} 
pichação baseiam-se na criação de películas impermeáveis que, comprovadamente, não apresentam boa durabilidade quando aplicada a materiais porosos. 


\section{REFERÊNCIAS BIBLIOGRÁFICAS}

ABADIE, M.; LIMAM, K.; ALLARD, F.. Indoor particle pollution: effect of wall texture on particle deposition. BUILDING AND ENVIRONMENT 36 (2001): 821817.

ASSOCIAÇÃO BRASILEIRA DE NORMAS TÉCNICAS - Método para avaliação de desempenho de tintas para edificações não industriais - Determinação da resistência de tintas e complementos ao crescimento de fungos em câmara tropical NBR 15301, Rio de Janeiro 2005.

AKBARI, H.; LEVINSON, R.; BERDAHL, P. A review of methods for the manufacture of residential roofing materials. Report Prepared by Lawrence Berkeley National Laboratory, 2003. 28p.

ALLEN, N.S.; EDGE, M.; VERRAN, J.; STRATTON, J.; MALTBY, J.; BYGOTT, C.. Photocatalytic titania based surfaces: environmental benefits. POLYMER DEGRADATION AND STABILITY 93 (2008) 1632-1646.

AMBRÓSIO JUNIOR, J.. Processos Oxidativos avançados (POA). Acessado em janeiro de 2008. www.iq.unesp.br/pet/poa.pps, acessado em janeiro de 2008

AMOROSO, G; FASSINA, V. Stone decay and conservation - atmosferic pollution, cleaning, consolidation and protection. ELSEVIER, Amsterdam, 1983, 453p.

BALLESTER, M; GONZALEZ, R. Basic methodology for the assessment and selection of water-repellent treatments applied on carbonatic materials. PROGRESS IN ORGANIC COATINGS 43 (4): 258-266 DEC 2001.

BASHEER, P.; LONG, A. Protective qualities of surface treatments for concrete. Proc. Instn Civ. Engrs Structs \& Bldgs, 1997, 122, Aug., 339 - 346.

BECKER, R. Patterned staining of rendered facades: hygro-thermal analysis as means for diagnosis. JOURNAL OF THERMAL ENVIRONMNET \& BUILDING SCIENCE. V. 26, n.4, april 2003. p.321-341.

BELDENS, Anne. An environment friendly solution for air purification and selfCleaning effect: the application of $\mathrm{TiO}_{2}$ as photocatalyst in concrete. Disponível em http://www.brrc.be/pdf/tra/tra_beeldens_txt.pdf, acessado em janeiro de 2008.

BELLAN, L; SALMON, L; CASS, G. A study on the human ability to detect soot deposition onto works of art. ENVIRONMENTAL SCIENCE \& TECHNOLOGY 34 (10): 1946-1952 MAY 152000 
BELLARDITA, M; ADDAMO, M; DI PAOLA, A; PALMISANO, L. Characterization of $\mathrm{TiO}_{2}$ thin films for photocatalytic application. International SYMPOSIUM ON PHOTOCATALYSIS, ENVIRONMENT AND CONSTRUCTION MATERIAIS, October 2007, Florence, Italy

BIRON, M. Understanding hydrophobic, liquid-repellent, lipophilic polymers (Lotus-effect). 2004. Disponível em www.specialchem4polymers.com, acessado em janeiro de 2008

BRIMBLECOMBE, P; GROSSI, C. Aesthetic thresholds and blackening of stone buildings. SCIENCE OF TOTAL ENVIRONMENT (2005) 15;349(1-3):175-89

CAI, CR.; VAN, G.M., AW, P.K., ITOH, K. Solar-driven self-cleaning coating for painted surface. C.R. CHIMIES 9 (2006), p. 829-835

CASSAR, L.; PEPE, C.; TOGNON , G.; GUERRINI, G.; AMADELLI, R. White cement for architectural concrete, possessing photocatalytic properties. Proceeding OF INTERNATIONAL CONGRESS ON THE CHEMISTRY OF CEMENT, 11, Durban, 2003.

CASSAR, L. Photocatalysis of cimentitious materials: clean building and clean air. MRS Bulletin/ May 2004. P.1-4.

CALDAS E SILVA, A. Durabilidade de compositos reforçados com fibras de celulose. Dissertação(mestrado), Universidade de São Paulo. 2002.

CHAROLA, E. Water-repellent treatments for building stones: a practical overview. APT BULLETIN, Vol. 26, No. 2/3. (1995), pp. 10-17.

CHEN, D.; LI, K. Photocatalytic coating on road pavement/structure for $\mathrm{NO}_{\mathbf{x}}$ abatement. Annual Report Submited to Houston Advanced Research Center and Office of Air Quality Planning and Standards. 2007, p.17.

CHEN, F.; YANG, X.; WU, Q. Antifungal capability of TiO2 coated film on moist Wood. BUILDING AND ENVIRONMENT 44 (2009) 1088-1093.

CHEN, J.; POON, C. Photocatalytic construction and building materials: from fundamentals to applications. BUILDING AND ENVIRONMENT 44 (2009) 18991906

CHENG, P.; ZHENG, M.; HUANG, Q.; JIN, Y.; GU, M. Enhanced photoactivity of silica-titania binary oxides prepared by sol-gel method. JOURNAL OF MATERIALS SCIENCE LETTERS 22, 2003, 1165 - 1168

CHENG, Y.; RODAK, D.; WONG, C.; HAYDEN, C.. Effects of micro- and nanostructures on the self-cleaning behaviour of lotus leaves. NANOTECHNOLOGY 17 (2006) 1359-1362.

CHEW, M.; TAN, $P$. Façade staining arising from design features. CONSTRUCTION AND BUILDING MATERIALS, v 17 (2003), p.181-187 
CHIOVITTI, D.; GONÇALVES, M.; RENZULLO, A. Performance evaluation of water repellents for above grade mansory. DURABILITY OF BUILDING MATERIALS AND COMPONENTS, 8. Canada. 1999. p.561-570.

CHU, H.; LIN, L.; LIU, H.; CHEN, H.; LIU, H.; CHEN, K. Photocatalytic properties of silicone polyesters using calcium phosphate/titanium dioxide. JOURNAL OF APPLIED POLYMER SCIENCE, Vol. 114, 413-419 (2009).

CLARKE, J.; JOHNSTONE, C. ; KELLY, N.; MCLEAN, R.; ANDERSON, J.; ROWAN, N.; SMITH, J. A Technique for the prediction of the conditions leading to mould growth in buildings BUILDING AND ENVIRONMENT, V. 34, ISSUE 4, 1 July 1999, Pages 515-521

CORONADO, J.; JAVIER, A. CONESA, J.; YEUNG, K.; AUGUGLIARO, V.; SORIA, J.. EPR Study of the surface characteristics of nanostructured TiO2 under UV irradiation LANGMUIR, 2001, 17 (17), 5368-5374.

DAVIDSON, CLIFF; TANG, WEI; FINGER, SUSAN; ETYEMEZIAN, VICKEN; STRUNEGEL, MARY; SHERWOOD, SUSAN. Soiling patterns on a tall limestone building: change over 60 years. ENVIRONMENTAL SCIENCE \& TECHNOLOGY 34 (4), p.560-565, 2000.

DIAMANTI, M.V.; BRUNELLA, M.F.; PEDEFERRI, MP.; PIROTTA, C.; MANZOCCHI, $P .$, CURTONI, S. Self-cleaning and antipolluting properties of Tio2-containing cementitious materials. CLEANTECH 07. 23-24 may 2007

DIAMANTI, M.V.; ORMELLESE, M.; PEDEFERRI, MP. Characterization of photocatalytic and superhydrophilic properties of mortars. CEMENT AND CONCRETE RESEARCH 38 (2008) 1349-1353

DORSEY, J.; PEDERSEN, H.; HARRAHAN, P. Flow and changes in appearance. International Conference on Computer Graphics and Interactive Techniques, 2996, p. 411-420

DOULOS, L.; SANTAMOURIS, M.; LIVADA, I. Passive cooling of outdoor urban spaces. The role of Materials. SOLAR ENERGY 77 (2004) 231-249.

DOW CORNING. Silicone chemistry overview. Disponível em http://www.dowcorning.com/content/publishedlit/51-960A-01.pdf. acessado em agosto de 2007.

ESBERT, R.; SANCHES, J.. Hidrofugación de rocas carbonatadas porosas: propriedades que controlan su eficácia. MATERIALES DE CONSTRUCCIÓN. V. 45, n.237, 1995. p.15-30.

FERNANDES, C. F. Estudo dos processos de condensação e migração de umidade em meios porosos consolidados. análise experimental de uma argamassa de cal e cimento. Dissertação (mestrado). Universidade Federal de Santa Catarina, Florianópolis, 1990. 135p. 
FERREIRA, A.P. Conservação de pedras graníticas- estudo da acção de Hidrófugos. Lisboa, 1993, 193p. Dissertação (mestrado) - Instituto Superior Técnico, Universidade de Lisboa

FLORES, M. Estratégia de manutenção: elementos da envolvente de edifícios correntes. Dissertação (mestrado), - Instituto Superior Técnico, Universidade de Lisboa, 2002.

FUJISHIMA, AKIRA; RAO, T.; TRYK, D. Titanium dioxide photocatalysis. Journal of Photochemistry and Photobiology C: Photochemistry Reviews 1 (2000) 1-21

FURUMURA, T.; TOKUSHIGE, H.; KAWAKAMI, M. Physical properties and $\mathrm{NO}_{\mathbf{x}}$ remediation of cement mortar incorporating titanium dioxide powder. JOURNAL OF THE SOCIETY OF MATERIALS SCIENCE, Japan, vol. 55, n. 10, pp. 923-928, 2006

GASPAR, P.; BRITO, J. Mapping defect sensitivity in external mortar renders. CONSTRUCTION AND BUILDING MATERIALS. 2005 - in press.

GERDES; A.; MEIER, S.; WITTMANN, F.. A new application technology for water repellent surface treatment. Proceeding of HYDROPHOBE II, Zürich, September 1998, Aedifico Publisher pp. 217-230

GRUNEWALD, J. Building environmental modeling and simulations. Notas de aula da Universidade de Syracuse e disponível em http://bauklimatikdresden.de/downloads/courses/2_Material_Properties.ppt

GROSSI, C.; ESBERT, R.; DAZ-PACHE, F.; ALONSO, F.J. Soiling of building stones in urban environments. BUILDING AND ENVIRONMENT 38(2003) 147159.

GUAN, K.; Lu, B.; YIN, Y. Enhanced effect and mechanism of SiO2 addition in superhydrophilic property of TiO2 films. SURFACE AND COATINGS TECHNOLOGY 173 (2003) 219-223

GUAN, K. Relationship between photocatalytic activity, hydrophilicity and selfcleaning effect of TiO2/SiO2 films. SURFACE AND COATINGS TECHNOLOGY 173 (2005) 219-223.

HABIBI, MH.; NASR-ESFAHANI, M. Preparation, characterization and photocatalytic activity of $\mathrm{TiO}_{2} /$ methylcellulose nanocomposite film derived from nanopowder $\mathrm{TiO}_{2}$ and Modified sol-gel Titania. J. MATER SCI (2007) 42: 6027-6035.

HAMILTON, R.S.; REVITT, D.M.; VINCET, K.J.; BITLIN, R.N. Sulphur and nitrogen particles polluant deposition on to building Surface. THE SCIENCE OF TOTAL ENVIRONMENT 167, 1995, p.57-66.

HANEHARA, S. Eco-cement and eco-Concrete. Apresentado em COE Workshop on "Material Science in 21st Century for the Construction Industry - Durability, Repair 
and Recycling of Concrete Structures. http://www.eng.hokudai.ac.jp/COEarea/workshop/pdf/05aug11 hanehara.pdf, acessado em janeiro de 2009.

HASHIMOTO, H.; TERAJI, T.; ITO, T. Impact ionization phenomenon in singlecrystalline rutile TiO2. Applied Surface Science, Volume 244, Issues 1-4, 15 May 2005, Pages 394-398

HERRMANN, J.; PÉRUCHON, L.; PUZENA, E.; GUILLARD, C. Photocatalysis: from fundamentals to self-cleaning glass applications. International Symposium on Photocatalysis, Environment and Construction Materiais, 8-9 Actober 2007, Florence, Italy.

HSIEH, C; CHEN, J; KUO, R; LIN, T; WU, C. Influence of surface roughness on water- and oil-repellent surface coated with nanoparticles. APPLIED SURFACE SCIENCE. 240 (2005) p.318-326.

HUSKEN, G.; BROUWERS, H.J.H. Air purification by cementitious materials:

Evaluation of air purifying properties. ICCBT2008, p263-274

HUSKEN, G.; HUNGER, M.; BROUWERS, H.J.H. Experimental study of photocatalytic concrete products for air purification. BUILDING AND ENVIRONMENT, Volume 44, Issue 12, 2009, p. 2463-2474

IRIE, H.; HASHIMOTO, K. Photocatalytic active surfaces and photo-induced high hydrophilicity/high hydrophobicity. ENV CHEM Vol. 2, Part M (2005): 425-450.

JANG, H.D.; KIM, S.; KIM, S. Effect of Particle Size and phase composition of titanium dioxide on photocatalytic properties. JOURNAL OF NANOPARTICLES RESEARCH 3: 141-147, 2001.

JANZ, M; JOHANNNESSON, B. Measurement of the moisture storage capacity using sorption balance and pressure extractors. JOURNAL OF THERMAL ENV. \& BLDG. SCI., Vol. 24-April 2001

JOHANSSON, A. Impregnation of concrete structures - transportation and fixation of moisture in water repellent treated concrete. Tese (doutorado). 2006.

JUNGHOON L., BO H.; PATANKAR, N. Contact angle hysteresis on rough hydrophobic surface. COLLOIDS AND SURFACES A: Physicochem Eng. 248 (2004), p.101-104.

KATZMAN, L. Building toward a cleaner environment: a new role for an existing product, TiO2. Sasazi Associates Inc. disponível no sítio http://ideas.sasaki.com/files/attachments/user370/cleaner\%20environment.pdf, acessado no dia 26 de setembro de 2009.

KOCI, K. ; OBALOVA, L.; MATEJOVA, L.; PLACHA, D.; LACNY, Z.; JIRKOVSKY, J.; SOLCOVA, O. Effect of TiO2 particle size on the photocatalytic reduction of CO2. Applied Catalysis B: Environmental 89 (2009) 494-502

KUNZEL, H.M.; KIEBL, K. Drying of brick walls after impregnation. Bauinstandetzens (1996) pp. 87-100. Disponível no sitio 
http://www.hoki.ibp.fraunhofer.de/ibp/publikationen/fachzeitschriften/drying_of_brick_ walls.pdf, acessado no dia 26 de setembro de 2007.

KUNZEL, H.; SEDLBAUER, K. Biologial growth on stucco. Buildings VIII / Wall Durability - Practices, Dec. 2001. http://www.ibp.fraunhofer.de/HT/pub/fachpub e/. Acessado em maio de 2005.

KUNZEL,H. SCHIMIDT, TH,; HOLM, A. Exterior surface temperature of different wall constructions comparison of numerical simulation and experiment. SYMPOSIUM FOR BUILDING PHYSICS, 11. 2002, p.441-449.

KURTH, J. Mitigation biofilm growth through the modification of concrete design and practice. Dissertação (mestrado). Georgia Institute of Technology, 2008. 160P.

KUS, H. Long-term performance of water-repellants on rendered autoclaved aerated concrete. Ganvle, 2002, 46p. tese (doutorado) - Centre for Built Environment, University of Gavle, Suecia

LACKHOFF, M.; PRIETO, X.; NESTLE, N.; DEHN, F.; NIESSNER, R. Photocatalytic activity of semicondutor-modified cement - influence of semiocondutor type and cement ageing. APPLIED CATALYSIS B: ENVIRONMENTAL 43 (2003), 205-216.

LAKSHMI, S.; RENGANATHAN, R.; FUJITA, S. Study on TiO2-mediated photocatalytic degradation of methylene blue. J. PHOTOCHEM A. CHEM. 88 (1995), 163-167.

LEWIS, M.; MCDONALD, W. Assuring the durability of stone facades in new construction. degradation of natural building stone. Mineapolis, Minessota, 1997, Proceedings of American Society of Civil Engeneering.p.116-137

LOCKINGTON, D.; PARLANGE, J.; BARRY, D.; LEECH, C. Drying of porous building material: hydraulic diffusivity and front propagation. MATERIALS AND STRUCTURE, Vol. 36, Augustu-September, 2003, pp.448-452

LORK, A. Silicone resin emultion paint: the perfect all-round façade protection. SLF Congress. 2003. disponível no sitio http://www.siliconharzfarben.com/online pdf/42.pdf. acessado em 01 de junho de 2005.

LU Z; ZHOU X; ZHANG J. Study on the performance of a new type of waterrepellent admixture for cement mortar. CEMENT AND CONCRETE RESEARCH 34 (11): 2015-2019 NOV 2004

LUNK; WITTMANN. The behavior of cracks in water repellent concretes structures with respect to capillarity water transport. Proceeding of HYDROPHOBE II, Zürich, September 1998, Aedifico Publisher pp. 63-76

LUIZ, A. P.; RIBEIRO, S; PANDOLFELLI, V. Artigo revisão: Uso da molhabilidade na investigação do comportamento de corrosão de materiais refratários. CERÂMICA 54 (2008) 174-183 
MÄÄTTÄ, J.; PIISPANEN, M.; KYMÄLÄINEM, H-R.; UUSI-RAUVA, A.; HURME, K. -R.; AREVA, S.; SJÖBERG, A. -M.; HUPA, L. Effects of UV-radiation on the Cleanability of Titanium Dioxide-coated glazed ceramic tiles. JOURNAL OF THE CERAMIC SOCIETY (2007), 27, 4569-4574.

MAGGOS, TH.; PLASSAIS, A.; BARTZIS, J.G.; VASILAKOS, CH.; MOUSSIOPOULUS, N.; BONAFAUOS, L. Photocatalytic degradation of $\mathrm{NO}_{\mathbf{x}}$ in a pilot street canyon configuration using $\mathrm{TIO}_{2}$-mortar panels. ENVIRONMENT MONIT. ASSESSMENT (2008), 136, 35-44

MARANHÃO, F.; BARROS, M. Fachada com placas de rocha na cidade de recife. CONGRESSO INTERNACIONAL DE ROCHAS ORNAMENTAIS, Guarapari/ES. 2005.

MARANHÃO, F.L.; JOHN, V.M.; CINCOTTO, M.A.; PILEGGI, R. J. Influência do tipo de cimento nas propriedades no estado fresco e endurecido das argamassas hidrofugadas com produtos à base de silicone. CONGRESSO DE ARGAMASSAS DE PORTUGAL, 2007.

MARANHÃO, F. L. ; JOHN, V. M. ; LOH, K. ; PILEGGI, R. G. . The influence of silicone-base water repellent as admixtures in the rheological properties of cement slurry. In: 5th INTERNATIONAL CONFERENCE ON WATER REPELLENT TREATMENT OF BUILDING MATERIALS, 2008. Proceedings of 5th International Conference on Water Repellent Treatment of Building Materials, 2008.

MARANHÃO, F.; SELLEY, D.; LOH, K.; JOHN, V. Performance of silicone water repellent for FRC corrugated roof tiles, INTERNATIONAL CONFERENCE ON DURABILITY OF BUILDING MATERIALS AND COMPONENTS, 11th, Istambul, Turquia, 2008

MAYERS, $H$. The chemistry and properties of silicone resins: network formers (in paints and renders) PIGMENT \& RESIN TECHNOLOGY Volume $27 \cdot$ Number 6 $1998 \cdot$ pp. 364-373

MCGETTIGAN, E Factors affecting the selection of water-repellent treatments. APT Bulletin, Vol. 26, No. 4, PRESERVATION OF HISTORIC MASONRY. (1995), pp. 22-26.

MELO MJ, BRACCI S, CAMAITI M. Photodegradation of acrylic resins used in the conservation of stone. POLYMER DEGRADATION AND STABILITY 66 (1): 23-30 1999.

MENDES, N. Desenvolvimento de um código genérico para a análise da transferência de calor e umidade em elementos porosos de edificações. Tese(Doutorado). Universidade Federal de Santa Catarina, Florianópolis, 1997. $225 p$.

MEROUANI, L. Phénomènes de sorption et de transfert d'humidité dans des matériaux du bâtiment - étude expérimntale comparative d'um mortier de 
ciment et d'um enduit de façade. Tese (doutorado). L'Institut National polytechnique de Grenoble. L'Intitut de mécanique de Grenoble. 1987, 180p.

MILLS, A; LEE, S. A web-based overview of semiconductor photochemistrybased current commercial applications. JOURNAL OF PHOTOCHEMISTRY AND PHOTOBIOLOGY A: CHEMISTRY, 152 (2002), 233-247

MILLS, A; WANG, J; MCGRADY, M. Method of rapid assessment of photocatalytic Activities of Self-Cleaning Films. J. PHYS, CHEM. B. (2006), 110, 18324-18331.

MILLS, A; WANG, J; MCGRADY, M. Photocatalytic oxidation of soot by P25 $\mathrm{TIO}_{2}$ films. CHEMOSPHERE (2006), 64, 1032-1035.

MOLLER. E. Dirt on exterior surface of building envelope. PROCEEDINGS BUILDING PHYSICS, $6^{\mathrm{TH}}$ NORDIC SYMPOSIUM. Disponível em http://www.gensnano.com/articles/dirt on exterior surfaces.pdf, acessado em maio de 2008.

MOLLER, E. Hygrothermal performance and soiling of exterior building surface. Denmark, 2003, 229p. Tese (doutorado) - Departament of Civil Engeneering, technical University of Denmark.

MOTOHASHI, K; INUKAI, T. Self-cleaning performance evaluation of commercial coatings throught 5 years outdoor exposure. International Symposium on Photocatalysis, Environment and Construction Materiais, 8-9 Actober 2007, Florence, Italy.

MUGGLI, D.; DING, L. Photocatalytic performance of sulfated $\mathrm{TiO}_{2}$ and Degussa P-25 $\mathrm{TiO}_{2}$ during oxidation of organics. APPLIED CATALYSIS B: ENVIRONMENTAL 32 (2001). p. 181-194.

NOGUEIRA, R; JARDIM, W F. A Fotocatálise heterogênea e sua aplicação ambiental. QUÍMICA NOVA, 21(1) (1998)

NORVAISIENÉ, R.; MINIOTAITÉ, R.; STAKEVICIUS. Climatic and air effetcs on building façade. MATERIALES SCIENCE (MEDZIAGOTYRA). V. 9, n. 1, 2003. 12105.

O'LENICK, A. Silicones - basic chemistry and selected applications. JOURNAL OF SURFACTANTS AND DETERGENTS, Vol. 3, No. 2 (April 2000), PP.387-393

OLIVEIRA, A. Revisão da indústria mineral de titânio. Dissertação (Mestrado), Universidade de São Paulo, 1997, 89p.

PARKIN, I.; PALGRAVE, R. Self-cleaning coatnings. Journal of Materials Chemistry2005, 15, 1689-1695

PEPE, C.; AMANDELLI, R.; PIMPINELLI, N.; CASSAR, L. Doped-TiO2/cemet Matrices Photoactive Materials. Proc. Of the RILEM Int. Symp. On environmentconscious materials and system sustainable development (Koriyama 6-7, Sept. 
2004. http://www.italcementi.it/newsite/tx millennium/files/pubblicazioni/AmadelliKoriyama2004.pdf

PEL, L.; LANDMAN, K. A sharp drying front model. DRYING TECHNOLOGY Vol. 22, No. 4, pp. 637-647, 2004

PEREZ, A.R. Umidade nas edificações. São Paulo, 1986, 271p. Dissertação (mestrado) - Escola Politécnica, Universidade de São Paulo.

PESAVA, P.; AKSU,R.; TOPRAK, S.; HORVATH, H.; SEIDL, S. Dry deposition of particles to building surface and soiling. THE SCIENCE OF THE TOTAL ENVIRONMENT 235, p.25-35, 1999.

PIO, C.A.; RAMOS, M.M.; DUARTE, A.C. Atmospheric aerosol and soiling of external surfaces in an irban environment. ATMOSFERIC ENVERONMENT V.32, N.11 pp.1979-1989, 1998

PRASAD, R.; DANIELS, S.CAMERON, D.C.; TULLY. E.. KENNEDY, R.O. Biocompatible coatings with silicone and titanium oxides deposited be PECVD. Disponível em www.miics.net/2006/download/63prasa.pdf, acessado em agosto de 2009.

POON, C.S.; CHENG, E. NO removal efficiency of photocatalytic paving blocks prepared with recycled materials. CONSTRUCTION AND BUILDING MATERIALS, 21 (2007) 1746-1753

POTENZA, G.; LICCUILLI, A.; DISO, D.; FRANZA, S.; CATIA, A.; LETTIERI, M.; CICCARELLA, G. Surface engeneeruing on natural stone through $\mathrm{TiO}_{2}$ photocatalytic coatings. INTERNATIONAL SYMPOSIUM ON PHOTOCATALYSIS, ENVIRONMENT AND CONSTRUCTION MATERIAIS, October 2007, Florence, Italy

RABL, A. Air pollution and buildings: an estimation of demage cost in France. ENVIRONMENT IMPECT ASSESSMENT REVIEW, 19(1997) 361-385, disponível no sitio http://www-cep.ensmp.fr/francais/themes/impact/pdf/Rabl1999a.pdf.

RAO, V.; SUBRAHMANYAM, M.; BOULE, P. Immobilized $\mathrm{TiO}_{2}$ photocatalytuc during long-term use: decrease in Activity. APPLIED CATALYSIS B: ENVIRONMENTAL 49 (2004), 239-249.

RIVAS, T.; PRIETO, B.; SILVA, B. Permeability to water vapour in granitic rocks. application to the study of deleterious effects of conservation. BUILDING AND ENVIRONMENT, V. 36, Issue 2 , February 2001, p.239-246

RUOT, B. PLASSAIS, A.; OLIVE, F.; GUILLOT, L.; BONAFOUS, L. TiO2-containing cement pastes and mortars: Measurements of the photocatalytic efficiency using a rhodamine B-based colourimetric test. SOLAR ENERGY, vol. 83, issue 10, October 2009, Pages 1794-1801.

SADAUSKIENE, J.; RAMANAUSKAS, J.; STANKEVICIUS, V. Effect of hydrophobic materials on water impermeability and drying of finish brick masonry. MATERIALS SCIENCE, Vol. 9, N. 1, 2003. Pp. 94-98 
SANDIN, K. Mansory water repellents. Proceedings of 7th INTERNATIONAL CONFERENCE ON DURABILITY OF BUILDING MATERIALS AND COMPONENTS, 7DBMC. Stocolmo, Suecia, Maio, 1996. 553-561p.

SANTOS.V. Imobilização de TiO2 em concreto. 2004. Dissertação (Mestrado) Universidade Federal de Itajubá. 103 p.

SANTOS, V.; KONDO, M. Imobilização de $\mathrm{TiO}_{2}$ em concretos: fotodegradação de Clorofórmio e Fenol. QUÍMICA NOVA, 29, N. 2, 251-255, 2006.

SATO, N. Análise da porosidade e das propriedades de transporte de massa de concretos com vista à avaliação de suas durabilidades. São Paulo, 1998, 172p. Tese (doutorado)- Escola Politécnica da Universidade de São Paulo

SATO, N; UEMOTO, KAI L; SUIRAKAWA, M; SHADE, R. Condensação de vapor de água e desenvolvimento de microorganismos em fachadas de edifícios: estudo de caso. ENCONTRO NACIONAL DE TECNOLOGIA DO AMBIENTE CONSTRUÍDO, 9. 2002, p.1191-1198.

SAYILKAN, F.; ASILTURKM, M.; SENER, S.; ERDEMOGLU, S; ERDEMOGLU, M.; SAYILKAN, H. Hydrothermal synthesis, characterization and photocatalytic activity of Nanosized TiO2 Based Catalysts for Rhodamine B Degradation. TURK J CHEM 31 (2007) , 211 - 221.

SCHUEREMANS, L.; VAN GEMERT, D.; FRIEDEL, M.; GIESSLER-BLANK, S. Durability of hydrophobic agents applied in a marine environment. 5th International Conference on Water Repellent Treatment of Building Materials Aedificatio Publishers, 1- 11 (2007).

SEDLBAUER, K. The prediction of mould fungus formation on and inside building elements. Stutgard, 2001, 155p. tese (doutorado) - Fraunhofer Institute for Building Physics, University of Stutgard.

SELLEY, D. Silicone chemistry. 2006. Apresentação enviada por correio eletrônico.

SELLEY, D.; MARANHÃO, F.; LOH, K.; JOHN, V. Silicone water repellents for (FRC) Fibre-Cement Boards. In: 10th INTERNATIONAL INORGANIC-BONDED FIBER COMPOSITES CONFERENCE, 2006, São Paulo. Proceedings of the IIBCC 2006. São Paulo : Universidade de São Paulo \& University of Idaho, 2006. v. 1. p. 14-24.

SENG, C.; LIN, T.; TAN, S. Paint material durability - PSB's experience. MASTEC, 2006, disponível em http://www.hkpc.org/hkiemat/mastec03 notes/07.pdf, acessado em janeiro de 2007

SHAHIDZADEJ-BONN, N.; AZOUNI, A.; COUSSOT, P. Effect of wetting properties on the kinetics of drying of porous media. JOURNAL OF PHYSICS: CONDESED MATTER, n. 19, 112101, 2007. 7pp. 
SHIRAKAWA, M. A. ; GAMBALE, W. ; GAYLARDE, C. C. ; Peter Gaylarde ; Neide Sato ; JOHN, V. M. . Acompanhamento da colonização de fungos em pinturas de fachadas durante 22 meses em São Paulo. In: 80 Congresso Internacional de Tintas, 2003, Sao Paulo. Anais do 80 Congresso Internacional de Tintas, 2003

SHIRAKAWA, M; JOHN, V.; GAYLARDE, C. Mould and phototroph growth on masonry facades after repainting. MATERIALS AND STRUCTURES 37 (271): 472-479 AUG-SEP 2004

SHOHET, I.; PACIUK, M. Service life prediction of exterior cladding components under standard conditions. CONSTRUCTION MANAGEMENT AND ECONOMICS 22 : 1081-1090 DECEMBER 2004

SILVA B, RIVAS T, PRIETO B. Consolidating and water repellent treatments applied to wet and salt contaminated granite. MATERIALES DE CONSTRUCCION 50 (257): 15-31 JAN-MAR 2000

SOUZA, A. Imobilização de $\mathrm{TiO}_{2}$ para tratamentos de efluentes líquidos. Dissertação (mestrado), Universidade Federal de Itajuba, 2003, 105p.

SYNNEFA, A.; SANTAMOURIS, M.; APOSTOLAKIS, K. On the development, optical properties and thermal performance of cool colored coatings for the urban environment. SOLAR ENERGY (2006)

TAN, C. Photocatalytic performance of titanium dioxide in coating formulation. Monografia (conclusão de curso). Faculty of Engineering, Physical Sciences and Architecture, Univeristy of Queensland, 2004. 66p.

TANAKA, K.; CAPULE, M.; HISANAGA, T. Effect of crystallinity of Ti02 on its photocatalytic action. CHEMICAL PHYSICS LETTERS, v. 187, Issues 1-2, 29 November 1991, Pages 73-76.

TITTARELLI, F.; MORICONI, G.; FRATESI, R. Influence of silane-based hydrophobic admixture on oxygen diffusion through concrete cement matrix. Proceedings of Sixth Int. Conference CANMET/ACI 2000, Nice, 2000, pp. 431-445.

TONOLI, G. H. D. ; SANTOS, S. F. ; JOAQUIM, A. P. ; SAVASTANO JR, H. . Accelerated carbonation on vegetable fibre reinforced Cimentitious roofing tiles. In: 10th INTERNATIONAL INORGANIC-BONDED FIBER COMPOSITES CONFERENCE, 2006, São Paulo, 2006. v. 1. p. 14-24.

TURKINGTON, AV; MARTIN, E; VILES, HA; SMITH, BJ. Surface change and decay os sandstone samples exposed to a polluted urban atmosphere over sixyears period: Belfast northern Ireland. BUILDING AND ENVIRONMENT 28 (2003), 1205-1216

URZI, C.; De LEO. Evaluation of the efficiency of water-repellent and biocide compounds against microbial colonization of mortars. INTERNATIONAL BIODETERIORATION \& BIODEGRADATION 60 (2007) P.25-34.

VALLÉE, F.; Ruot, B.; Bonafous, L.; Guillot, L.; Pimpinelli, N.; Cassar, L.; Strini, A.; Mapelli, L.; Schiavi, L.; Gobin, C.; André, H.; Moussipoulos, N.; Papadopoulos, A.; 
Bartzis, J.; Moggos, T.; McIntyre, R>; Lehaut-Burnouf, C.; Hentichsen, A.; Laugesen, P. Amandelli, R.; Kotzias, D.; Pichat, P. Innovative Self-cleaning and de-pollution Façade Surface. CIB World Congress 2004. www.italcementi.it/newsite/tx millennium/files/pubblicazioni/CIB-2004final-

submission130204.pdf acessado em janeiro de 2007

VERHOEF. Soiling and Cleaning of Building Facades. Taylor \& Francis 2007. 200p.

WADE, J.. An investigation of $\mathrm{TiO}_{2}-\mathrm{ZnFe}_{2} \mathrm{O}_{4}$ Nanocomposities for visible light photocatalysis. Dissertação (mestrado). University of South Florida, Department of Electrical Engenheering. 108p. March 2005.

WATKISS, P.; EYRE, N.; HOLLAND, M.; RABL, A.; SHORT, N. Impacts of air

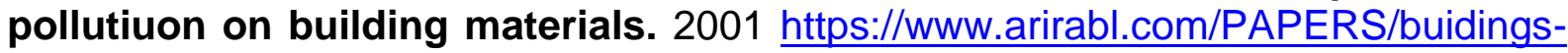
PollAtmos.pdf. acessado em Janeiro de 2006.

WINKLER, E. M. Stone: Properties, Durability on Man's Environment. SPRIGERVERLAG, New York, 1973

YAN, L; WANG, K; YE, L. Super Hydrophobic Property of PVDC/CaCO3 nancomposities coatings. JOURNAL OF MATERIALS SCIENCE LETTER 22, 2003, P.1713-1717.

YAN, X.; OHNO, T.; NISHIJIMA, K.; ABE, R.; OHTANI, B. Is Methylene Blue an Appropriate Substrato for a Photocatalytic Test? A Study with Visible-Light Responsive Titania. CHEMICAL PHYSICS LETTERS, 429 (4-6): 606-610

YOKOTA, H.; AKIRA, Y.; KATO, E.; DAÍ, J. CHORIDE Ingress in Cracked Concrete with Water Repellent Treatment. The 3rd ACF INTERNATIONAL CONFERENCE-ACF/VCA 2008

YU, J. Deactivation and Regeneration of Environmentally Exposed Titanium Dioxide $\left(\mathrm{TiO}_{2}\right)$ Based Products. Acessado no dia 22 de janeiro de 2008 http://www.epd.gov.hk/epd/english/environmentinhk/air/studyrpts/files/reportupdatedcb paving blocks 2003.pdf

YURANOVA, T.; SARRIA, V.; JARDIM, W.; RENGIFO, J.; PULGARIN, C.; TRABESINGER, G.; KIWI, J. Photocatalytic discoloration of Organic Compounds on Outdoor Building Cement Panels Modified by Photoactive Coatings. Journal of Photochemistry and Photobiology A: Chemistry, 188 (2007), 334-341

ZAN, L.; PENG, S.; XIA, Y.; HUANH, L.. Novel route to prepare $\mathrm{TiO}_{2}$-coated ceramic and its photocatalutic Function. Journal of Materials Seince 39 (2004) 761-763.

ZHANG, T. ET AL., Photooxidative N-demethylation of methylene blue in aqueous TiO2 dispersions under UV irradiation. JOURNAL OF PHOTOCHEMISTRY AND PHOTOBIOLOGY A: CHEMISTRY 140 (2001) 163-172

ZHAO, Q.; LIU, Y.; WANG, C.; WANG. S.; MÜLLER-STEINHAGEN, H. Effect of surface free energy on the adhesion of biofouling and crystalline fouling. 
CHEMICAL ENGINEERING SCIENCE Volume 60, Issue 17, September 2005, Pages 4858-4865

ZUGNO, L.A; HURLOW, E. Métodos de monitoramento para controle Efetivo de Microorganismos. XVII ENCUENTRO NACIONAL DE QTIC, BRASIL 2005. 
Anexo A: Difratometria de raios- $X$ do semiconductor utilizado 
Escola Politécnica da Universidade de São Paulo Departamento de Engenharia de Minas e de Petróleo

Laboratório de Caracterização Tecnológica - LCT

Av. Prot. Melo Moraes, 2373 - CEP 05508-030 Săo Paulo-SP emal: Ictelct.poll.usp.br

TEL: ( OXX11 ) 3091-5151

FAX ( OXX11) 3091-6037

mursulatipolluspor

\section{RESULTADO DE IDENTIFICAÇÃO DE FASES POR DIFRATOMETRIA DE RAIOS X}

CERTIFICADO: $435 / 09$

DATA: $31 / 08 / 2009$

CLIENTE: VANDERLEY MOACYR JOHN

AMOSTRA: Dióxido de titânio

IDENT. LCT: $369-1689 . \mathrm{HPF}$

\section{MÉTODO}

O estudo foi efetuado através do método do pó, mediante o emprego de difratômetro de raios X, marca PANalytical, modelo X'Pert PRO com detector X'Celerator.

A identificação das fases cristalinas, abaixo discriminadas, foi obtida por comparação do difratograma da amostra com os bancos de dados PDF2 do ICDD - International Centre for Diffraction Data (2003) e PAN-ICSD - PANalytical Inorganic Crystal Structure Database (2007).

\section{RESULTADOS}

Os resultados obtidos estão listados na tabela abaixo:

\begin{tabular}{cllll}
\hline ICDD & Nome do Composto & Fórmula Química & Mineral & Obs \\
\hline 01-073-1764 & Anatásio & $\mathrm{TiO}_{2}$ & Anatásio \\
01-087-0710 Rutilo & $\mathrm{TiO}_{2}$ & Rutilo \\
\hline
\end{tabular}

Nota: $p p=$ possivel presença

Em anexo é apresentado o difratograma obtido (cor vermelha), onde são assinaladas as linhas de difração correspondente(s) à(s) fase(s) identificada(s) (cada fase em uma cor distinta).

Juliana Livi Antoniassi Pesquisadora do LCT - EPUSP
Dra. Maria Manuela Lé Tassinari Pesquisadora do LCT - EPUSP
Prof. Dr. Henrique Kahn Coordenador do LCT 


\section{DIFRATOGRAMA DE RAIOS $\mathrm{X}$}

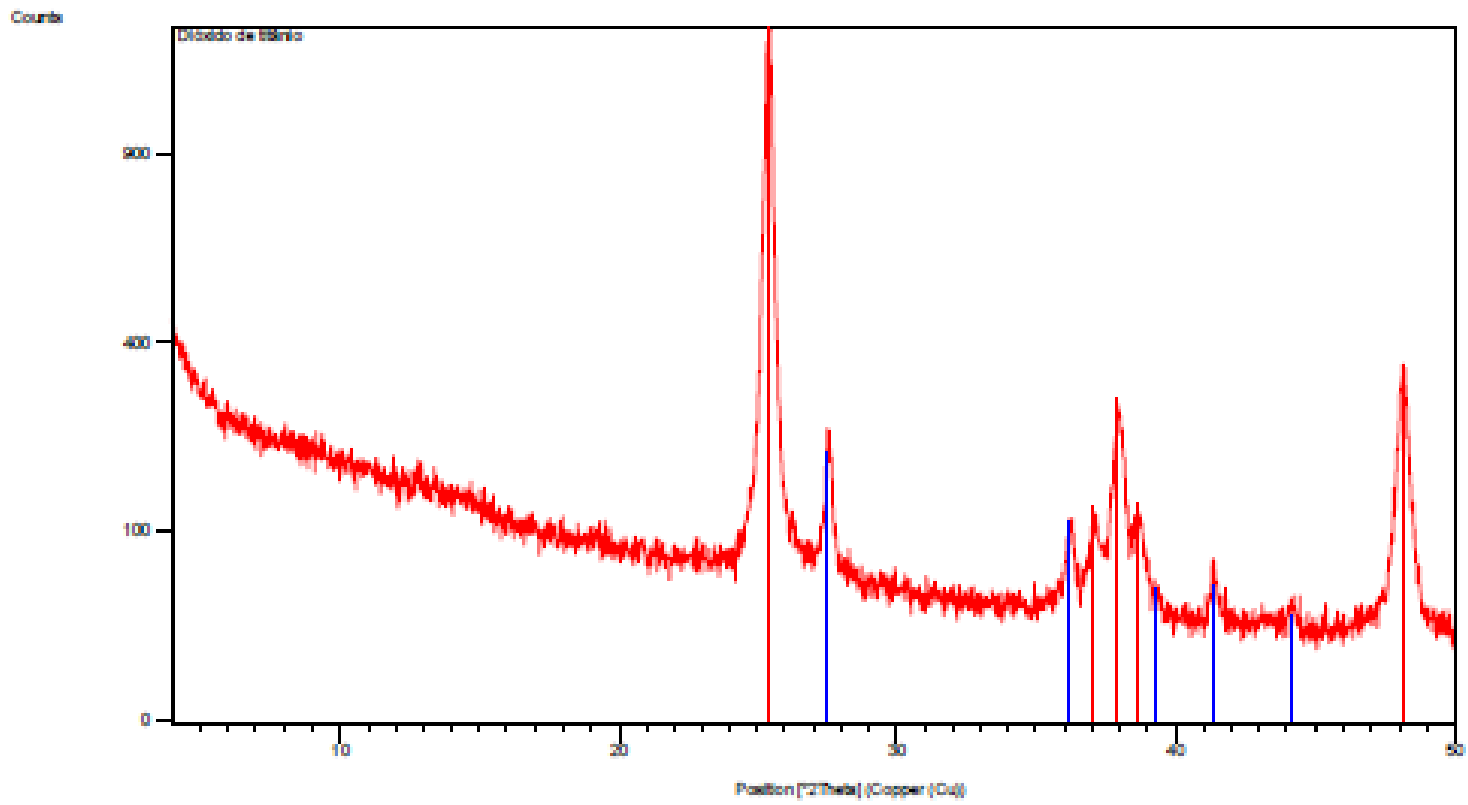

FASES IDENTIFICADAS

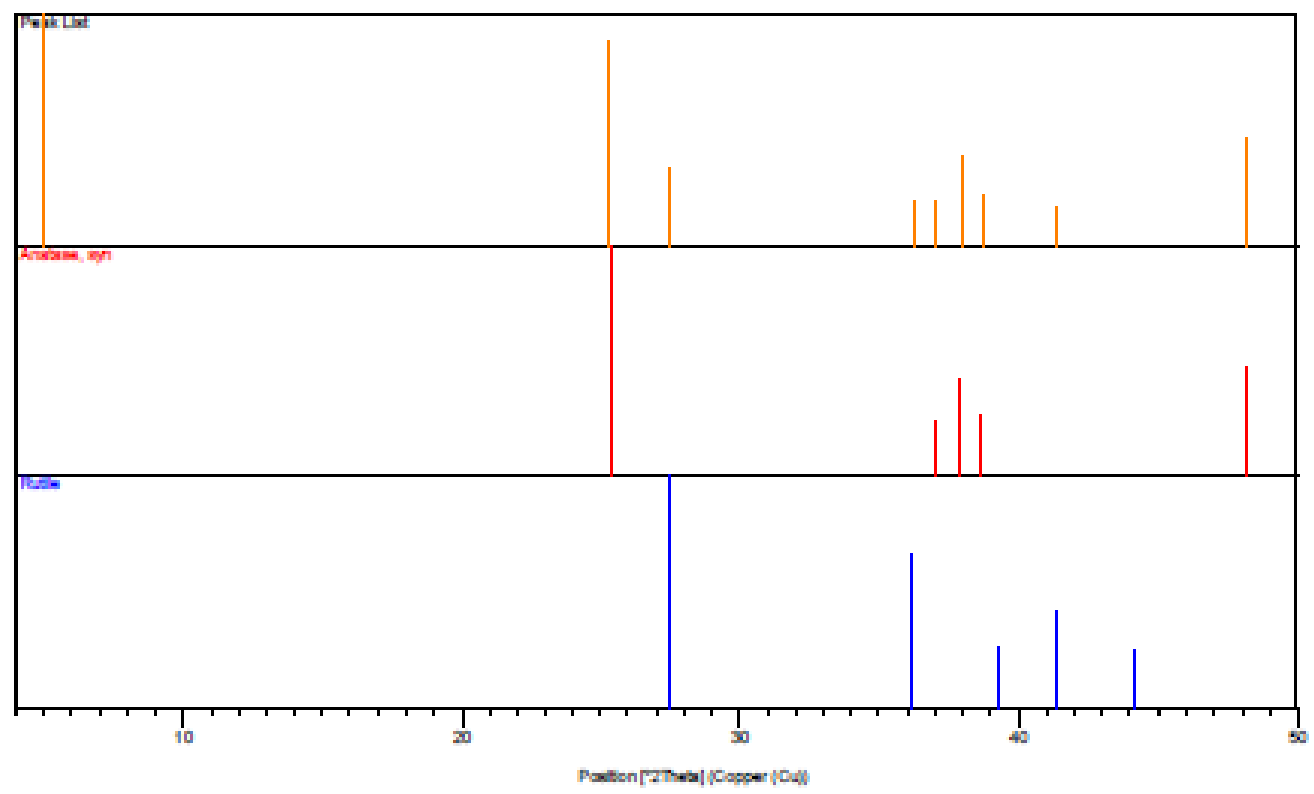

